GABRIEL RICARDO JARDIM CAIXETA

\title{
SILÊNCIO LEGISLATIVO, LIBERDADE PARA LEGISLAR E OMISSÃO INCONSTITUCIONAL
}

\author{
Dissertação de mestrado
}

Orientador: Prof. Dr. Roger Stiefelmann Leal

UNIVERSIDADE DE SÃO PAULO

FACULDADE DE DIREITO

SÃO PAULO

2015 
GABRIEL RICARDO JARDIM CAIXETA

\section{SILÊNCIO LEGISLATIVO, LIBERDADE PARA LEGISLAR E OMISSÃO INCONSTITUCIONAL}

Dissertação apresentada à Faculdade de Direito da Universidade de São Paulo como requisito parcial à obtenção do título de mestre, sob a orientação do Professor Doutor Roger Stiefelmann Leal, na área de Direito do Estado, subárea de Direito Constitucional.

UNIVERSIDADE DE SÃO PAULO

FACULDADE DE DIREITO

SÃO PAULO

2015 
Nome: CAIXETA, Gabriel Ricardo Jardim.

Título: Silêncio legislativo, liberdade para legislar e omissão inconstitucional

Dissertação apresentada à Faculdade de Direito da Universidade de São Paulo como requisito parcial à obtenção do título de mestre, sob a orientação do Professor Doutor Roger Stiefelmann Leal, na área de Direito do Estado, subárea de Direito Constitucional.

\section{BANCA EXAMINADORA}

Prof. Dr.:

Instituição:

Julgamento: Assinatura:

Prof. Dr.: Instituição:

Julgamento: Assinatura:

Prof. Dr.: Instituição:

Julgamento: Assinatura: 


\section{AGRADECIMENTOS}

As limitações deste trabalho podem até refletir as do candidato, mas não a sua gratidão. Independente do resultado do julgamento pela banca, a oportunidade de ter convivido, na Faculdade de Direito da Universidade de São Paulo, com pessoas brilhantes (professores, alunos e servidores) e também a de ter seus horizontes expandidos por discussões, aulas, palestras e leituras antes inimagináveis já é, para ele, motivo de grande satisfação. Concedeu-lha o professor Roger Stiefelmann Leal. Aceitar um desconhecido entre seus orientandos; dedicar-lhe tempo (e quanta paciência!); mostrar-lhe caminhos a seguir; e, além disso, provocar ideias e reflexões e tudo dentro do mais apurado profissionalismo, da seriedade incontestável, do rigor científico notório: eis os motivos pelos quais o candidato agradece, em primeiro lugar, o seu orientador.

De nada adiantaria a oportunidade oferecida pelo insigne professor não fossem os Deputados Jardel Sebba e Hélder Valin e as Procuradoras Gerais da Assembleia Legislativa do Estado de Goiás, as Dras. Otavila Alves Pereira de Gusmão e Regiane Dias Meira Rodrigues, que lhe deferiram a imperiosa licença para que pudesse se afastar do exercício de seu cargo, cumprir os créditos do curso e redigir a dissertação. Deve ser lembrada a disposição dos demais colegas procuradores em suportar o aumento da carga de trabalho gerada pela ausência do mestrando. A eles é dirigido um agradecimento muito especial. Em particular, ele agradece a Dra. Ruth Barros Pettersen da Costa, jurista brilhante, pelo estímulo, pelas discussões e pelas sugestões na feitura do trabalho.

O ingresso no mestrado e a vida em São Paulo tornaram-se possíveis também graças aos velhos amigos de sempre: Natália Salgado Goulart, Valéria Gomes Ferreira e João Frederico Wirth Bertrand Chaibub, pelo apoio logístico, desde a fase de seleção, e pela companhia indispensável. Mas a vida em São Paulo não seria a mesma sem os novos amigos de sempre: Karina Denari, Rebecca Gröterhörst, Juliana Demarchi, Eduardo Marrochio e Marcelo Doval Mendes. A todos, muito obrigado! Ele agradece a Danielle M. do Amaral, Luciana N. G. Abrantes, bibliotecárias do MPF/GO, e Ana Maria Santos, do MPF/PA, pela ajuda na coleta de material bibliográfico.

Sem o apoio de seus pais e irmãos, o mestrando não teria conseguido apresentar este trabalho. A Ana Taís, mais do que isso: pela paciência, pela compreensão e pelo companheirismo, todo o agradecimento do mundo será ainda irrisório. 
A Ana Taís,

Para quem tudo o que há de melhor nesse mundo foi feito. 


\section{RESUMO}

CAIXETA, Gabriel Ricardo Jardim. Silêncio legislativo, liberdade para legislar e omissão inconstitucional. Dissertação de mestrado. Faculdade de Direito da Universidade de São Paulo, 2015.

O trabalho analisa o conceito de omissão inconstitucional. A pesquisa parte da liberdade dada pela Constituição ao legislador quanto à decisão de legislar ou não, ou, pelo menos, de decidir quando legislar. Isso implica compreender o silêncio legislativo como opção política tolerada. A dissertação examina também as origens do fenômeno da inconstitucionalidade por omissão. Finalmente, o estudo analisa critérios úteis à configuração de uma obrigação de legislar, extraídos de características específicas das normas constitucionais, como a competência, a reserva de lei, questões políticas e as normas programáticas.

PALAVRAS-CHAVE: liberdade de legislar; silêncio legislativo; omissão inconstitucional; dever de legislar; normas constitucionais 


\section{RÉSUMÉ}

CAIXETA, Gabriel Ricardo Jardim. Silence législatif, liberté pour légiférer et omission insconstitutionnelle. Dissertassion de maîtrise. Faculté de Droit de l'Université de São Paulo, 2015.

Le travail analyse le concept de l'omission insconstitutionnelle. La recherche démarre par la liberté donnée par la Constitution au législateur en ce qui concerne sa décision de légiférer ou pas, ou au moins de décider quand il doit légiférer. Cela implique de bien comprendre le silence législatif comme option politique tolérée. La dissertation examine aussi les origines du phénomène de l'insconstitutionnalité par omission. Enfin, l'étude analyse des critères utiles à la configuration de l'obligation de légiférer, extraits des caractéristiques spécifiques des normes constitutionnelles, comme la compétence de légiferer, la réserve de loi, les questions politiques et le normes programmatiques.

MOTS-CLÉS: liberté pour légiférer; silence législatif; omission insconstitutionnelle; devoir de légiférer; normes constitutionnelles 


\section{SUMÁRIO}

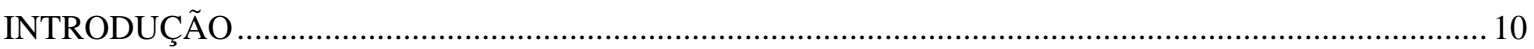

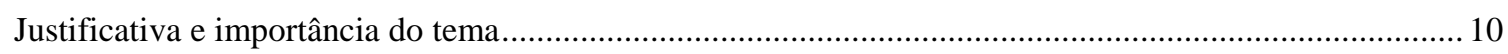

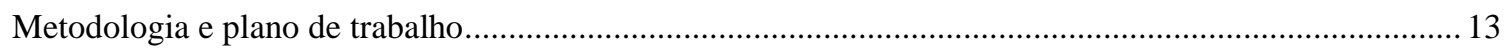

1 O SILÊNCIO DO LEGISLADOR COMO LIBERDADE DE LEGISLAR ...................................................... 16

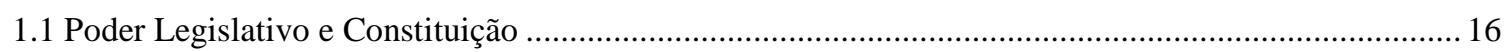

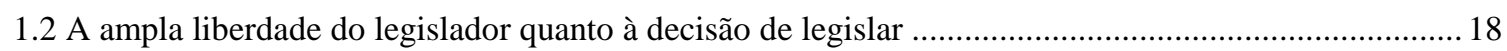

1.2.1 A atividade legislativa nos constitucionalismos revolucionário e oitocentista .................................. 18

1.2.2 A atividade legislativa no período novecentista: do início do século até a Segunda Guerra Mundial

1.2.3 O caráter executável ou não-executável das normas constitucionais como fundamento para a

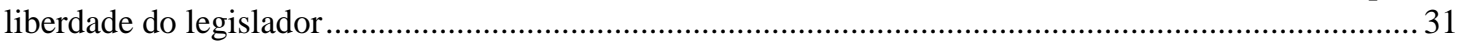

1.3 A liberdade de legislar no constitucionalismo democrático.................................................................. 34

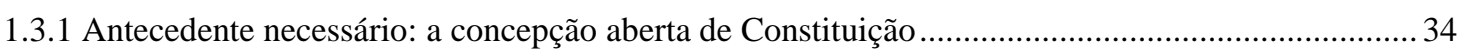

1.3.2 A atividade legislativa no constitucionalismo pós-Segunda Guerra Mundial.................................. 42

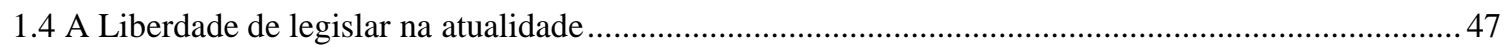

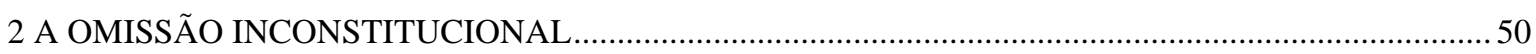

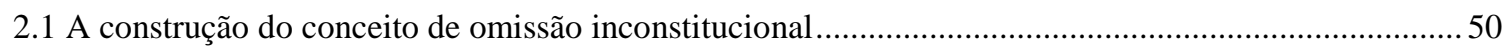

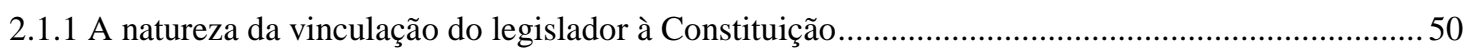

2.1.2 As origens do reconhecimento da inconstitucionalidade por omissão ............................................ 57

2.1.2.1 A atuação do Tribunal Constitucional Federal alemão …………………………….................5

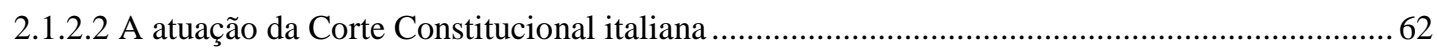

$2.2 \mathrm{O}$ descumprimento de um dever de legislar como principal parâmetro para aferição da ocorrência de

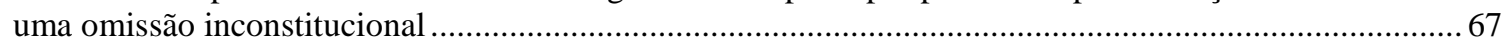

2.3 Os diferentes modos de compreender e controlar a inconstitucionalidade por omissão .......................... 70

2.3.1 O controle da omissão inconstitucional como censura ao comportamento desidioso do legislador70

2.3.2 O controle da omissão inconstitucional a partir de um resultado normativo decorrente do

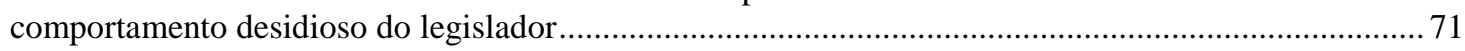

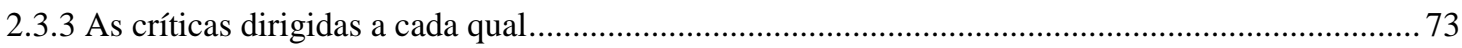

2.3.4 A evolução e o "estado da arte" do tratamento do conceito de omissão inconstitucional no Brasil78

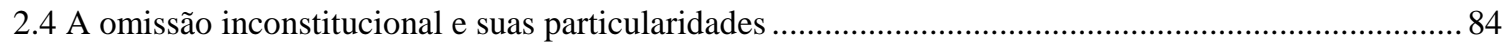

2.4.1 O direito subjetivo à norma e a correlação com a inconstitucionalidade por omissão ...................... 84

2.4.2 O elemento temporal como possível componente da omissão inconstitucional ............................... 89

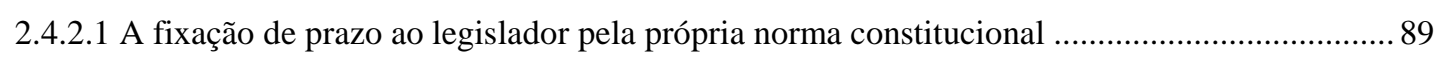

2.4.2.2 Interpositio legislatoris sem fixação de prazo pela norma constitucional .................................. 91

2.4.3 As qualificações do descumprimento do dever específico de legislar. Os tipos de omissões

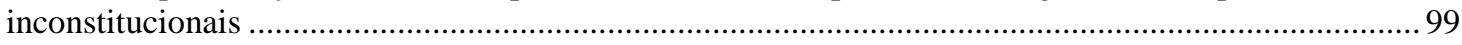

3 O DEVER DE LEGISLAR E CARACTERÍSTICAS ESPECÍFICAS DAS NORMAS

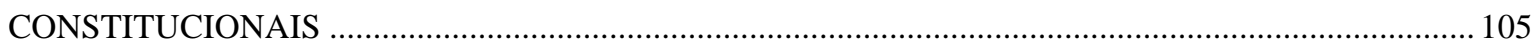

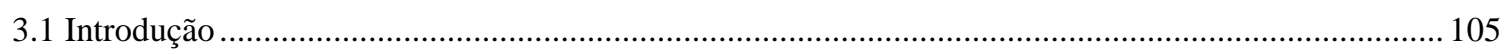

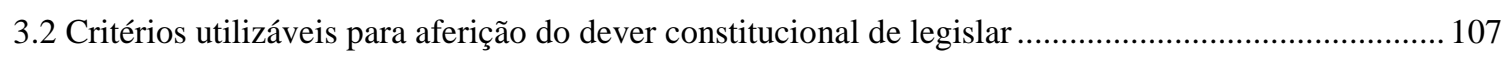




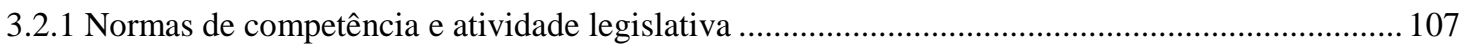

3.2.2 O critério do prazo certo fixado pela norma .......................................................................... 113

3.2.3 A reserva de lei imperativa e a reserva de lei dispositiva como parâmetros para a delimitação do dever específico de legislar .................................................................................................... 115

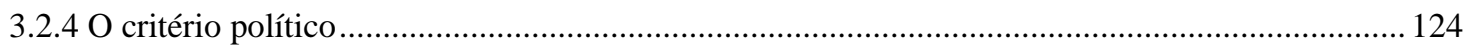

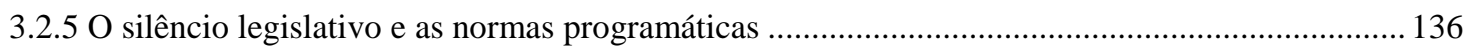

3.2.6 Normas programáticas e políticas públicas ............................................................................ 143

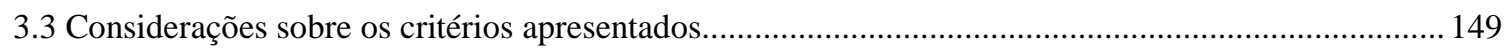

3.4 Outros critérios utilizados pela doutrina e jurisprudência a partir de lei existente.............................. 152

3.4.1 O dever de proteção dos direitos fundamentais ..................................................................... 153

3.4.2 O dever de adequação de leis vigentes.................................................................................... 155

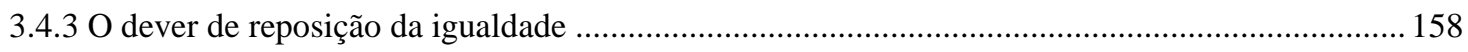

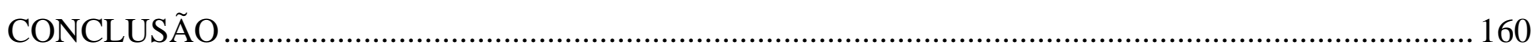

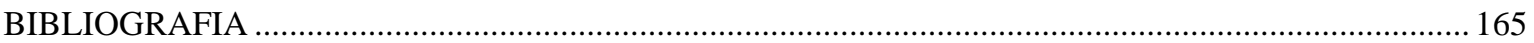




\section{INTRODUÇÃO}

\section{Justificativa e importância do tema}

Não se diga que no Brasil se legisla pouco.

Conforme as últimas estatísticas elaboradas somente no âmbito da Câmara dos Deputados $^{1}$, em 2007, foram editadas 4 leis complementares, 133 leis ordinárias, 52 Decretos Legislativos (“acordos”), 333 Decretos Legislativos relativos a Radio e TV, 3 Decretos Legislativos relativos a outros assuntos e 1 Resolução da Câmara dos Deputados, no total de 529 atos. No ano seguinte, editaram-se uma lei complementar, 169 leis ordinárias, 62 Decretos Legislativos (“acordo"), 278 Decretos Legislativos relativos a Radio e TV, 2 Decretos Legislativos de outras naturezas e 8 Resoluções da Câmara dos Deputados.

O Ato Conjunto $n^{\circ}$ 2, de 2013, dos Presidentes do Senado Federal e da Câmara dos Deputados ${ }^{2}$, noticia que existem hoje mais de 180 mil atos normativos, entre leis, decretos, instruções normativas, portarias, decretos-leis, resoluções, muitos conflitantes entre si e com a própria Constituição.

Esses dados confirmam a inflação legislativa nesses tempos atuais de sociedade técnica e permitem que se proceda à comparação entre "multiplicação das leis e a inflação monetária" ${ }^{3}$. Além disso, são um indício da própria desvalorização da lei ${ }^{4}$.

Por outro lado, e aqui está o paradoxo, o legislador ainda se silencia muito.

É aquele mesmo Ato que o diz: existem 25 dispositivos constitucionais a serem regulamentados por lei complementar e 117, por lei ordinária. Tais desencontros motivaram a composição de uma comissão mista no Congresso Nacional visando consolidar a legislação existente e oferecer projetos de lei para a completa regulamentação

\footnotetext{
${ }^{1}$ Informações disponíveis em http://bd.camara.gov.br/bd/handle/bdcamara/6286 e http://bd.camara.gov.br/bd/bitstream/handle/bdcamara/2491/anuario_estatistico_legislativo2007.pdf?sequenc e=5. Acessos em 15/05/2013, às 20:45h.

2 Esse ato encontra-se publicado no Diário do Senado de 21/03/2013. Disponível em http://www6.senado.gov.br/diarios/BuscaDiario?tipDiario=1\&datDiario=21/03/2013\&paginaDireta=11520. Consultado em 07/04/2013, às 16:30h.

${ }^{3}$ Cf.CLÈVE, Clèmerson Merlin. Atividade legislativa do poder executivo. São Paulo : Editora Revista dos Tribunais, 2011, p. 54

${ }^{4}$ Cf. FERREIRA FILHO, Manoel Gonçalves. Do processo legislativo. São Paulo : Saraiva, 2012, p. 36.
} 
da Constituição Federal ${ }^{5}$. Em que pese a louvável iniciativa do Congresso, há nela um lado tragicômico. É que estipulou-se um prazo de 180 dias para a conclusão de um objetivo não alcançado em quase 25 anos de existência da atual Lei Fundamental. Ao que parece, nenhum resultado concreto foi produzido.

Inegável que essa ocorrência, muitas leis de um lado (várias delas certamente inúteis e de interesse público questionável) e, no contexto apresentado, silêncio legislativo, de outro, resulta certa perplexidade.

Não é difícil imaginar que, no âmbito do welfare state, o problema da omissão legislativa é tão sério quanto o da produção de uma lei que atenta contra a Constituição. E que torna mais dramático quando a norma ausente se relaciona com direitos fundamentais. No mesmo diapasão, dentre as várias modalidades de omissão do Poder Público, como as do executivo e até mesmo as do judiciário, as do Poder Legislativo atraem atenção especial, dada a relação direta do legislador com a Constituição ${ }^{6}$. Com efeito, é dele que se esperam providências a concreção das normas constitucionais e, por conseguinte, para a salvaguarda das "promessas constitucionais".

O constitucionalismo moderno, no entanto, é também produto da democracia e do pluralismo político que desta é consectário natural. A Constituição deve ser aberta a todas as formas de pensamento político - desde que condizentes com a própria democracia, claro está - justamente para abarcá-las e, portanto, deve permitir que o governo do dia possa ser livre a fazer escolhas conforme o programa vencedor nas urnas. Por isso mesmo, e para conferir a maleabilidade que essa ordem aberta requer, é que não se pode olvidar que há normas constitucionais que deixam maior espaço para a ponderação política que permeia toda decisão do legislador. E isso permite a escolha de vários tipos de comportamentos, inclusive o silêncio, sem que possa haver ingerência judicial.

Nesse aspecto, a liberdade de conformação do legislador é essencial à democracia. Esclareça-se desde já que essa liberdade compreende tanto o conteúdo legislado, quanto, principalmente, a decisão de legislar ou não (ou quando legislar). Se essa liberdade não deve ser confundida com arbitrariedade, de outro ângulo e em certos casos, não pode ser cerceada sob o fundamento de que o legislador, ao se calar, se transforma em poder constituinte por decidir quando tornar aplicável uma norma constitucional. Será

\footnotetext{
${ }^{5} \mathrm{O}$ Ato conjunto noticiado tem esse escopo.

${ }^{6}$ MIRANDA, Jorge. Manual de Direito Constitucional. Inconstitucionalidade e garantia da Constituição. Tomo VI. $4^{\text {a }}$ ed. Coimbra : Coimbra editora, 2013, p. 364.
} 
demonstrado, pela análise da doutrina e de alguns julgados do STF que a densificação de certos preceitos constitucionais foi relegada ao legislador pela dificuldade de se estabelecer consenso no seio da própria Assembleia Constituinte. Esses preceitos, de que é exemplo o art. $18, \S 4^{\circ}$, como bem assinalou o ministro Sepúlveda Pertence, em voto no Mandado de Injunção $\mathrm{n}^{\circ} 291$, foram assumidos como compromissos para o futuro, como adiamento de um problema, dadas a gravidade e a sensibilidade política da matéria.

A liberdade de conformação do legislador, no entanto, não é irrestrita. Em alguns casos, a Constituição manda, impõe, ordena ao legislador a tarefa de completar a norma, de fechar a ordem constitucional quando ela própria não preferiu fazê-lo.

E aqui começam os problemas a serem debatidos nessa dissertação.

É verdade que o constituinte desconfiou deveras do legislador ordinário. A par da previsão de instrumentos processuais para o reconhecimento e combate das omissões inconstitucionais, a própria Constituição deu soluções, ainda que provisórias, para problemas que, segundo suas escolhas, não poderiam esperar pela lei exigida. Como exemplos, podem ser citados os arts. 10 (proteção de relação de emprego contra despedida arbitrária e outros direitos trabalhistas, como a licença paternidade), 35, $\S 2^{\circ}$ (prazos para as leis orçamentárias) e os arts. $4^{\circ}, 12$ e 13, da Emenda Constitucional no 20/98, que tratam, respectivamente, da equivalência do tempo de serviço, previsto pela legislação vigente ao tempo do cumprimento dos requisitos de aposentadoria, ao tempo de contribuição; exigibilidade de contribuições previdenciárias previstas em lei destinadas ao custeio da seguridade social e dos diversos regimes previdenciários; e, finalmente, critérios para o pagamento de salário-família e auxílio-reclusão.

Mas, por outro lado, a Constituição sempre lhe atribuiu um papel obrigatoriamente proativo? A omissão legislativa causada pelo silêncio do Parlamento é sempre constitucionalmente relevante? Se não, como diferenciar a omissão como prática política legítima daquela que vulnera a Lei Maior?

A doutrina e a jurisprudência pátrias ainda não se detiveram, analítica e criticamente, sobre a delimitação do dever específico de legislar, que é o fundamento da inconstitucionalidade por omissão. Do exame de obras sobre o tema - manuais ou mesmo as monografias específicas, evidencia-se um salto argumentativo, ou, por assim dizer, uma lacuna teórica, um espaço vazio, entre o dever de legislar e uma norma preceptiva não exequível por si mesma. 
A propósito, a atenção maior é dada aos instrumentos processuais positivados no nível constitucional para combater o silêncio do legislador. Há, é certo, discussão sobre a inclusão das normas programáticas no rol de imposições constitucionais e outra envolvendo os direitos que podem motivar a impetração de mandado de injunção. Mas ainda não se elaborou uma resposta definitiva, ou pelo menos segura, sobre o que se deve entender por um silêncio vulnerador da Constituição. Daí a justificativa e importância do presente estudo.

Um dos objetivos da dissertação é tecer uma crítica a esse posicionamento. Além disso, serão oferecidos e analisados critérios teóricos que separam, dentro de um enfoque dogmático, a omissão legislativa que se situa ainda na esfera de liberdade do legislador da sua vertente inconstitucional. Isso implica considerar que nem toda remissão ao legislador, pela reserva de lei, acarreta um ordem ou uma imposição, isto é, um dever específico de legislar, portanto. Esses critérios se fundamentam em características específicas de normas constitucionais e nos modos pelos quais a Constituição remete determinada matéria ao legislador. Nesse sentido, destacam-se a atribuição de competência ao legislador, as reservas de lei, normas que portam consigo questões políticas e compromissos dilatórios. Quanto a este último aspecto, serão analisadas as normas programáticas em função do dever de legislar.

Não interessa a esse estudo apectos processuais da inconstitucionalidade por omissão, como a análise do cabimento, peculiaridades procedimentais ou limites da ação direta de inconstitucionalide por omissão ou do mandado de injunção, nem tampouco de outras técnicas decisórias criadas por Tribunais estrangeiros. À evidência, esses instrumentos serão mencionados, mas sem a preocupação de desvendar todas as discussões que os rodeiam.

\section{Metodologia e plano de trabalho}

Todo trabalho científico haverá que apresentar um objeto bem delimitado. O deste será, então, analisar o próprio conceito de inconstitucionalidade por omissão, em função da liberdade de conformação do legislador. Em comparação aos estudos tradicionais, o que segue adiante ficará um passo atrás, uma vez que, como se disse, não será dada prioridade a aspectos processuais da colmatação das omissões legislativas. 
Para o fim proposto, o trabalho será estruturado em três capítulos. O primeiro será destinado justamente a tratar dos âmbitos de liberdade do legislador quanto à decisão de legislar. Se, no constitucionalismo liberal clássico (ou oitocentista), em virtude da potestade do Parlamento, o legislador era absolutamente livre para decidir quando, como e se legislar, no constitucionalismo democrático novecentista, essa liberdade não mais é tão extensa. A meta é, então, estudar essa evolução e o espaço de liberdade de que ainda goza na atualidade.

O segundo capítulo será destinado à análise da omissão legislativa como uma inconstitucionalidade. Serão vistas as origens desse tipo de vulneração da Constituição, as concepções teóricas em torno dela, a visão que a doutrina e a jurisprudência brasileiras têm desse instituto e as consequências práticas de sua aceitação, como o eventual direito à norma e os diversos critérios classificatórios desenvolvidos.

Finalmente, no terceiro capítulo, será examinado o dever específico de legislar, a partir de critérios que têm como fundamento certas características das normas constitucionais. Consequentemente, será o momento oportuno para demonstrar que a Constituição, dentro de certas circunstâncias, mesmo que necessite do legislador para dar concreção a uma norma, não o obriga a fazê-lo. Será, assim, o momento adequado para oferecer as respostas às questões formuladas acima.

O método utilizado nesta dissertação é o dedutivo. Parte-se de um aspecto mais geral, a liberdade de conformação do legislador, estudam-se, em seguida, as origens da inconstitucionalidade por omissão para, finalmente, restringir o objeto ao exame dos deveres de legislar. Como salientado acima, para fins de corte metodológico, as omissões tratadas no trabalho se referem exclusivamente as do legislador. O âmbito teórico em que este trabalho se situa é o da dogmática jurídica, sem que se leve em consideração outras correntes existentes hoje no direito constitucional, como o neo-constitucionalismo ou póspositivismo. Neste enfoque, não se dará importância à distinção entre regras e princípios nem se farão maiores considerações sobre a possível força normativa destes.

Impende ressaltar que não será utilizado o método de direito comparado. Nada obstante, far-se-á uso constante tanto da doutrina estrangeira quanto da jurisprudência de Tribunais Constitucionais europeus, principalmente da Alemanha, Portugal, Espanha e Itália, países que influenciaram, uns mais, outros menos, o modo como as omissões legislativas são tratadas no Brasil. 
Apenas como nota propedêutica, informe-se que foi utilizada a grafia original nas citações diretas de autores clássicos brasileiros e dos juristas portugueses, bem como nas citações dos artigos de Constituições ou outros atos normativos brasileiros anteriores a 1988. 


\section{O SILÊNCIO DO LEGISLADOR COMO LIBERDADE DE LEGISLAR}

\subsection{Poder Legislativo e Constituição}

No século XVII, a Constituição escrita já era conhecida no mundo ocidental. A Inglaterra, com suas tradições e costumes que desaguaram no sistema Common Law, teve duas: o Instrument of Government, de 1653, é considerado o primeiro texto constitucional escrito inglês. Em 1657, foi sucedido por outro: o Humble Petition and Advice ${ }^{7}$. Ambos consagravam a separação entre Poder Legislativo e Poder Executivo.

Naquele tempo, ainda na Inglaterra, a atividade legislativa já houvera evoluído de um costume do direito medieval inspirado por elementos divinos, que deveria, então, ser declarado ou clarificado - sendo que a lei resultante desse processo era a corporificação da própria lei de Deus - para algo que poderia ser criado e interpretado pelos homens ${ }^{8}$. Além disso, o Poder Legislativo encontrara-se consolidado e pudera dar mostras que poderia ser também tirano, como aconteceu, primeiro, no caso do Parlamento Longo e o reinado de Carlos $\mathrm{I}^{9} \mathrm{e}$, posteriormente, em relação às colônias americanas. Voltar-se-á a este último caso mais adiante.

A partir dos movimentos revolucionários norte-americano e francês, no século XVIII, pode-se dizer que a concepção da Constituição como um documento escrito se dissemina no mundo ocidental. No entanto, na Europa Central, se depara com um problema que só será contornado no século XX: o de afirmar-se realmente como lei fundamental. E considerar uma Constituição como lei fundamental é reconhecer nela duas características essenciais. A primeira é que ela deveria ser a principal decisão política de um povo, da qual deveriam originar-se todas as outras decisões. A segunda, é que haveria de estabelecer-se como norma normarum do ordenamento jurídico nacional, como fonte jurídica proeminente, portanto ${ }^{10}$.

\footnotetext{
${ }^{7}$ Cf. PIÇARRA, Nuno. A separação de poderes como doutrina e princípio constitucional. Coimbra : Coimbra editora, 1989, pp. 58-59; VILE, J. M. C. Constitucionalism and separation of powers. Indianapolis : Liberty Funds, 1998, pp. 52 e 57.

${ }^{8}$ Cf. VILE, J. M. C. Constitucionalism and separation of powers, cit., p. 27.

${ }^{9}$ Cf. PIÇARRA, Nuno. A separação de poderes como doutrina e princípio constitucional, cit., p. 48

${ }^{10}$ Cf. ENTERRIA, Eduardo García de. La constitución como norma y el tribunal constitucional. Madri : Civitas, 1985, p. 55.
} 
Uma causa bastante importante desse problema, se não a primordial, coincide também com uma das causas dos principais problemas da própria Teoria do Estado ${ }^{11}$ : a soberania, entendida como a definição de quem deve ser o centro irradiador de decisões politicas condutoras do Estado.

Como se verá ao longo do capítulo, o exercício da soberania será determinante para as relações entre a Constituição e o Poder Legislativo, sendo que a definição do órgão soberano é que determinará a natureza dessas relações. Estas, esclareça-se desde logo para o que neste estudo interessa, dizem respeito ao grau de liberdade do legislador quanto à emanação de lei, tendo como referência a Constituição. De antemão, diga-se que sofreram alterações significativas no evoluir do constitucionalismo moderno, implicando uma mutação quanto aos espaços de liberdade do legislador.

É mister deixar assente ainda que essas relações se materializam mormente pelo artifício da reserva de lei. Por essa técnica, a Constituição incumbe ao legislador a função de inserir poder público nos espaços onde ela não o faz ${ }^{12}$, isto é, de proceder ao "fechamento" das normas constitucionais. Se o Parlamento exerce a soberania, qualquer tipo de indicação da necessidade de lei pela Constituição será inócuo. Se, ao contrário, a Constituição é manifestação da soberania do povo, então o Poder Legislativo, como poder constituído e, por consequência, destituído da condição de ente supremo, poderá ter restringido o espaço autônomo de decidir se e quando legislar (ou, em alguns casos, até eliminado).

Registre-se que, a rigor, a falta de remissão da norma constitucional ao legislador não necessariamente afasta do campo de atuação dele as questões por ela $\operatorname{tratada}^{13}$. No entanto, a utilização desse expediente (assim como a presunção de constitucionalidade da própria lei) fornece demonstração precisa sobre a "posição qualificada que ocupa o legislador no sistema constitucional"14, o que particularmente se evidencia no constitucionalismo democrático novecentista. É que, nesse caso, o Poder Legislativo corporifica, pelo menos ainda em alguma medida, o pluralismo de ideias e os

\footnotetext{
${ }^{11}$ Cf. KRIELE, Martin. Introducción a la Teoría del Estado. Fundamentos históricos de la legitimidad del Estado constitucional democrático. Buenos Aires : Depalma, 1980, p. 13. O outro, segundo esse autor, é a legitimidade.

12 A expressão “inserir poder público" é de MENÉNDEZ, Ignacio Villaverde Menéndez. La inconstitucionalidad por omisíon. Madri : MaGraw-Hill, 1997, p. 18.

${ }_{13}^{13}$ Nesse sentido: PANIAGUA, Enrique Linde. Constitución abierta. Madri : Linde Editores, 1991, pp. 13-14.

${ }^{14}$ MENÉNDEZ, Ignacio Villaverde. La inconstitucionalidad por omisíon, cit., p. 20.
} 
conflitos de interesses que permeiam a sociedade, tanto é que, em geral, as Constituições hodiernas ainda dão maior ênfase ao princípio representativo.

Cumpre enfatizar que o recurso à reserva de lei não é uma epifania das Constituições contemporâneas. Sejam as hauridas pelos movimentos revolucionários do final do século XVIII, ou aquelas produzidas ao longo do século XIX, de caráter marcadamente liberal e flexível, a atividade legislativa infraconstitucional jamais foi dispensada.

Assim, se não houve variação nas Constituições quanto à utilização do artifício da reserva de lei, mas se houve mudança quanto aos espaços ocupados pelo legislador e pela Constituição (que, ao que parece, não há dúvidas a respeito disso), releva descortinar, portanto, como eram essas relações durante o evolver do constitucionalismo. Essa é uma tarefa um pouco descritiva, é verdade, mas necessária para se avaliar o "valor" do silêncio legislativo como liberdade para legislar. Isso será feito no presente capítulo.

Advirta-se, entretanto, que, por falta de correspondência entre as questões que esse trabalho tenta resolver, não será abordada a discussão sobre a superação ou não do positivismo jurídico ou se há outras formas de dar "efetividade" às normas constitucionais mediante a utilização de outros caminhos, como o da atividade criativa da jurisdição constitucional. Por outro lado, afirme-se que isso não significa confundir a lei com o Direito, numa tentativa de ressuscitar o pensamento jurídico trazido a lume ao tempo da Escola da Exegese. Trata-se apenas de dar um recorte preciso ao trabalho e dar um sentido à pesquisa, evitando-se dispersões e temas de importância acessória.

\subsection{A ampla liberdade do legislador quanto à decisão de legislar}

\subsubsection{A atividade legislativa nos constitucionalismos revolucionário e oitocentista}

Afirmou-se que as Constituições nunca dispensaram a atuação legislativa. 
De fato, a Constituição americana de $1787^{15}$ atribui ao legislador o encargo de fixar a remuneração de Senadores e Representantes (Artigo I, Seção 6, 1); a Emenda III dispõe que "nenhum soldado poderá, em tempo de paz, instalar-se em um imóvel sem autorização do proprietário, nem em tempo de guerra, senão na forma a ser prescrita em lei”; a Emenda XIII remete ao Congresso a competência de dispor sobre a proibição de escravidão ou trabalhos forçados, salvo por condenação criminal. Da mesma forma, a Emenda XIV (que trata de direitos individuais, número de representantes dos Estados e dívida pública), as Emendas XV e XIX (direito de voto), Emenda XXIII (forma de indicação, pelo Distrito Federal, dos eleitores do Presidente e Vice-Presidente igual ao número de Senadores e Deputados no Congresso, a que teria direito se Estado fosse), atribuem ao Congresso a competência para "executar" as disposições nelas contidas.

A Constituição francesa de 1791 impunha ao Poder Legislativo o encargo de estabelecer, a todos os cidadãos, sem distinção, o modo pelo qual os nascimentos, casamentos e mortes seriam constatados (artigo $7^{\circ}$ ). À lei foi conferida a tarefa de fixar as regras que os servidores públicos municipais (Officiers Municipaux) deveriam seguir no exercício de suas funções (artigo 10). Não se olvide, ademais, que o texto constitucional previa a criação da seguridade pública e da instrução pública.

Por sua vez, a Constituição francesa de 1848 (II República) reconhecia a liberdade de ensino, sendo que tal liberdade se daria conforme as condições de capacidade e moralidade estabelecidas pela lei. Ademais, determinava, no artigo 27, que uma lei eleitoral disporia sobre as causas em que o cidadão francês perderia o direito de eleger ou ser eleito. Ao disciplinar sobre a Administração do Interior, no artigo 78, preconizava que “[u]ne loi déterminera la composition et les attributions des conseils généraux, des conseils cantonaux, des conseils municipaux, et le mode de nomination des maires et des adjoints" ${ }^{\text {. A }}$. lei também determinaria como seriam divididos os cantões para fins eleitorais (artigo 30) e quais seriam os crimes pelos quais responderia o Presidente da República (artigo 100).

\footnotetext{
${ }^{15}$ Constituição dos Estados Unidos da América - 1787. Versão eletrônica, em língua portuguesa, e disponível em: http://www.direitoshumanos.usp.br/index.php/Documentos-anteriores-\%C3\%A0cria\%C3\%A7\%C3\%A3o-da-Sociedade-das-Na\%C3\%A7\%C3\%B5es-at\%C3\%A9-1919/constituicao-dosestados-unidos-da-america-1787.html. Acesso em 04/09/2014, às 13:41h.

${ }^{16}$ Textos constitucionais franceses disponíveis em: http://www.conseil-constitutionnel.fr/conseilconstitutionnel/francais/la-constitution/les-constitutions-de-la-france/les-constitutions-de-lafrance.5080.html. Acessos em 04/09/2014, às 16:15.
} 
A Constituição de Cádis, de 1812, conquanto tivesse descrito longamente o processo de escolha dos deputados, previa que o Parlamento seria composto por cidadãos, conforme determinasse a lei (artigo 27). O Poder Legislativo também deveria dispor sobre a Regência (artigo 195), os orçamentos da Família Real e do Poder Judiciário (arts. 212 e ss. e 256), a competência dos ministérios e o salário dos Ministros (chamados de "Secretários de Estado", arts. 224 e 230), etc.

No Brasil, a Constituição de 1824 dava à lei a tarefa de regular "o modo pratico das Eleições, e o numero dos Deputados relativamente á população do Imperio" (artigo 97); de estabelecer a forma de concessão de carta de naturalização, a cargo do Imperador (artigo 102); de determinar a natureza dos delitos praticados por Ministros (traição, corrupção, falta de observância da lei e prática de atos atentatórios à liberdade, segurança e propriedade dos súditos) e a maneira de processá-los (artigo 134); de fixar atribuições e competências dos Presidentes das Províncias (artigo 166). Em relação à proteção dos direitos individuais, a lei era necessária para disciplinar: os casos em que não se violaria o direito de domicílio durante o dia (artigo 179, VII); os casos de prisão sem culpa formada (179, VIII); as penas a que ficavam sujeitos os juízes responsáveis por prisões arbitrárias (artigo 179, X); os casos de indenização pelo uso de propriedade particular por parte do poder público (artigo 179, XXII); o direito adquirido às recompensas por serviços prestados por civis ou militares a favor do Estado (artigo 179, XXVIII).

Pelo fato de a reserva de lei ter sempre acompanhado as Constituições, há quem defenda que "a ocorrência fáctica de cenários omissivos do dever constitucional de legislar não nasceu com as Constituições programáticas". E também que, se não houve um tratamento teórico do desvalor da omissão legislativa, é porque a própria concepção de direitos no Estado de Direito liberal era claramente negativa ${ }^{17}$.

Com efeito, durante o constitucionalismo da era liberal, a função do legislador era o de impedir o Estado de imiscuir-se na autonomia privada do indivíduo, que, "de per si, em competição com os demais, haveria de conquistar o próprio bem estar" ${ }^{\prime 1}$. A função da lei devia ser, portanto, protetiva ${ }^{19}$. Com efeito, isso fica bem claro de acordo com o

\footnotetext{
${ }^{17}$ Cf. MORAIS, Carlos Blanco. Justiça Constitucional. Tomo II. O contencioso constitucional português entre o modelo misto e a tentação do sistema de reenvio. Coimbra : Coimbra editora, 2005, p. 462.

${ }^{18}$ Cf. FERREIRA FILHO, Manoel Gonçalves. Estado de Direito e Constituição. São Paulo : Saraiva, 2007, p. 42.

${ }^{19}$ Assim: VERGOTTINI, Giuseppe de. Diritto Costituzionale. Pádua : CEDAM, 2006, p. 187, para quem a previsão de reserva de lei nas constituições da monarquia constitucional implicava afirmar a supremacia do parlamento.
} 
texto de algumas Constituições da época, que previam (ou ainda preveem) limites à atividade legislativa.

Nesse sentido, diz a Emenda I, da Constituição Americana: “[c]ongress shall make no law respecting an establishment of religion, or prohibiting the free exercise thereof; or abridging the freedom of speech, or of the press; or the right of the people peaceably to assemble, and to petition the Government for a redress of grievances" 20 . A Constituição Francesa de 1791 possuía disposição semelhante: "[1]e Pouvoir législatif ne pourra faire aucunes lois qui portent atteinte et mettent obstacle à l'exercice des droits naturels et civils consignés dans le présent titre, et garantis par la Constitution ; mais comme la liberté ne consiste qu'à pouvoir faire tout ce qui ne nuit ni aux droits d'autrui, ni à la sûreté publique, la loi peut établir des peines contre les actes qui, attaquant ou la sûreté publique ou les droits d'autrui, seraient nuisibles à la société" ${ }^{21}$. O artigo $4^{\text {o, da }}$ Constituição de Cádis, de 1812, estava redigido nestes termos: "La nación está obligada á conservar y proteger por leyes sabias y justas, la libertad civil, la propiedad, y los demás derechos legítimos de todos los indivíduos que la componen". ${ }^{22}$

Essas decisões constitucionais são explicáveis também pelos limites do próprio Estado de Direito, num contexto de separação entre Estado e sociedade. A reserva de lei certamente corporificava tal contraposição, que, ao final, resultava também no antagonismo entre Direito e Estado (ou, o que dá no mesmo, entre Direito e Poder), visto que a lei, expressão da vontade geral e votada pelos representantes do povo, era confundida com o próprio Direito ${ }^{23}$. Não se olvide que o Estado de Direito, denominação de matriz alemã, possuía índole racional e estava a serviço do interesse comum dos homens. Portanto, o ordenamento estatal devia ter como referência obrigatória o indivíduo livre, igual, autodeterminado, bem como seus objetivos na vida terrena. Neste aspecto, devia limitar-se a promover a segurança e a liberdade da pessoa, bem como a proteção da propriedade, no intuito de possibilitar o desenvolvimento das potencialidades de cada qual $^{24}$.

20 Disponível em http://www.archives.gov/exhibits/charters/constitution_transcript.html. Acesso em 04/09/2014, às 18:00h.

21 Disponível em http://www.conseil-constitutionnel.fr/conseil-constitutionnel/francais/la-constitution/lesconstitutions-de-la-france/constitution-de-1791.5082.html. Acesso em 04/09/2014, às 18: 30h.

22 Texto original extraído de: http://www.cervantesvirtual.com/obra-visor/constitucion-politica-de-lamonarquia-espanola-promulgada-en-cadiz-a-19-de-marzo-de-1812-... Acesso em 04/09/2014, às 19:00h.

${ }^{23}$ Cf. VAZ, Manuel Afonso. Lei e Reserva da Lei. A causa da lei na Constituição portuguesa de 1976. Coimbra : Coimbra editora, p. 171.

${ }^{24}$ BÖCKENFORDE, Ernst-Wolfgang. Estudios sobre el Estado de Derecho y la Democracia. Madri : Editorial Trotta, 2000, pp. 19-20. Conquanto não sejam conceitualmente iguais, o Rechstaat, o Rule of Law e 
À evidência, os exemplos tirados das constituições liberais supracitadas dão conta que a lei era reclamada para fins organizacionais, para dar forma ou existência a vários institutos. Os casos mais comuns estavam ligados aos sufrágios, à composição e a atribuições de órgãos de diversas naturezas (conselhos, Juízes de Paz, forma de recrutamento das forças armadas, etc). Isso não contradiz o fato de que a natureza por excelência da atividade legislativa era a de tutelar os direitos individuais, pela restrição às ações interventivas do Estado. De todo modo, se percebe na lei a função de conferir certa determinação conteudística, e, consequentemente, exequibilidade total a diversas normas constitucionais.

No ponto, impende ressaltar que não é incorreta a observação segundo a qual a lei ordinária se fazia necessária para dar operatividade à parte dogmática das Constituições oitocentistas, que, quando existia, se expressava apenas por princípios muito gerais ${ }^{25}$. A propósito, era essa a concepção reinante de Constituição durante aquele período. Devia ser da natureza das Constituições prever somente os lineamentos gerais da organização política que instituem, os seus princípios gerais e as atribuições dos diferentes órgãos do governo, "mas em geral, sem descer aos meios particulares e às providências próprias de execução" ${ }^{26}$, evitando-se, pois, casuísmos. Atendo-se a esse esquema organizatório, a

o État légal convergem para fins comuns: submissão do poder político ao Direito, pela legalidade e separação dos poderes, no intuito de conferir proteção ao cidadão e às suas potencialidades (Cf. CANOTILHO, J J Gomes. Direito Constitucional e Teoria da Constituição. Coimbra : Almedina, 2003, p. 93). Consultar ainda SAMPAIO, José Adércio Leite. O Estado Democrático de Direito. In: HORBACH, Carlos Bastide; ALMEIDA, Fernando Dias Menezes de; AMARAL JÚNIOR, José Levi Mello do; LEAL, Roger Stiefelmann. Direito Constitucional, Estado de Direito e Democracia. Homenagem ao Prof. Manoel Gonçalves Ferreira Filho. São Paulo : Quartien Latin, 2011, p. 296-297. Para Michel Troper, as expressões relativas ao Estado de Direito designam dois tipos de relação entre o Estado e o Direito: ou significa que o Estado se submete a uma ordem jurídica que lhe é exterior ou que o Estado age por meio do Direito. De todo modo, sustenta que tais concepções não são conciliáveis com a ideia de democracia ou com os direitos do homem. Ainda que se diga que o Estado de Direito seja uma garantia à liberdade, há a necessidade de se compreender como uma ou outra concepção busca realiza-la. Ao negar que isso possa mesmo acontecer, ele conclui que a expressão Estado de Direito ou é uma contradição em termos ou simplesmente uma tautologia (Cf. La théorie du Droit, le Droit, L'état. Paris : Presses Universitaires de France, 2001, p. 271). Atente-se que há vasta bibliografia que explica as características do Estado, desde os albores do Estado Liberal, da qual podem ser citados, dentre outros: FERREIRA FILHO, Manoel Gonçalves. Estado de Direito e Constituição, cit.; MIRANDA, Jorge. Teoria do Estado e da Constituição. Coimbra : Coimbra editora, 2002, pp. 68 e ss.; FIORAVANTI, Maurizio. Costituzionalismo. Percorsi della storia e tendenze attuali. Roma : Editori Laterza, 2009; FIORAVANTI, Maurizio. Stato e costituzione. Materiali per una storia delle dottrine costituzionali. Turim : G. Giappicheli Editore, 1993; ABENDROTH; Wolfgang; FORSTHOFF, Ernst; DOERHING, Karl. El Estado Social. Madri : Centro de Estudos Constitucionales, 198; ZAGREBELSKY, Gustavo. Il diritto mite. Milão : Einaudi, 1992; CARRÉ DE MALBERG, Raymond. Teoría General del Estado. Cidade do México : Fondo de Cultura Económica, 1998; MATTEUCCI, Nicola. Lo stato. Bolonha : il Mulino, 1997, etc.

${ }^{25}$ Cf. ENTERRÍA, Eduardo Garcia. La Constitucion como norma y el Tribunal Constitucional. Madri : Civitas, 1985, p. 55.

${ }^{26}$ Cf. CAVALCANTI, João Barbalho Uchoa. Constituição Federal Brasileira: Commentarios. Rio de Janeiro : F. Briguiet e Cia Editores, 1924, p. 188. 
Constituição contribuiria para a manutenção de seu caráter maleável, isto é, "adaptável a épocas e circunstâncias diversas, destinada, como é, a [sic] longevidade excepcional"27.

É verdade que a questão posta em termos simplistas, considerando o papel do legislador levando-se em conta tão-somente a reserva de lei, esconde complexidades hoje bem conhecidas. A mais significativa delas, e isso foi mencionado acima, diz respeito à definição sobre quem deveria exercer a soberania.

Cabe, neste momento, uma explicação, por oportuna. Foi dito, em linhas volvidas, que o Parlamento inglês, órgão tão caro aos britânicos, por ser garantia de independência e liberdade, também foi protagonista de períodos de tirania. Foi em um desses períodos que eclodiu a própria revolução americana.

Em termos assaz sintéticos, cumpre asseverar que a insurgência dos colonos americanos justificou-se pela dificuldade de obtenção de maior representatividade naquela instituição. Ironicamente, é a representação o princípio mais eloquente do próprio constitucionalismo inglês. A questão se agravou por questões tributárias: o Parlamento impôs uma série de ônus às Colônias (como a Lei do Açúcar e a Lei da Moeda, de 1764, e a Lei do Aquartelamento e a Lei do Selo, de 1765), sufocando a economia local. Assim, "por terem começado acreditando-se britânicos, vivendo sob uma constituição livre, (...) supunham desfrutar dos direitos civis, das liberdades constitucionais, das virtudes políticas e das liberdades naturais que vinham atreladas a isso" ${ }^{28}$. Mas, uma vez descortinada a índole autoritária do Parlamento, "foi então que descobriram o quanto realmente o Parlamento estava longe e como eles compreendiam pouco essa instituição ou aqueles cujas vidas estavam intimamente vinculadas a ela" ${ }^{29}$.

O motivo da breve narrativa empreendida é bem simples: no caso americano, o comportamento absolutista do Parlamento inglês provocou, em última análise, o exercício de uma das mais extraordinárias construções advindas daquele período, o poder constituinte. Finda a revolução, o poder constituinte alçou a Constituição de 1787 à condição de Lei Suprema, porque era manifestação decorrente da soberania do titular do

\footnotetext{
${ }^{27}$ Cf. MAXIMILIANO, Carlos. Comentários á Constituição brasileira. $4^{\mathrm{a}}$ ed. São Paulo e Rio de Janeiro : Livraria e Editora Freitas Bastos, 1948, p. 128. Consigne-se que essa era a mesma orientação da $1^{a}$ edição desta obra, de 1918, o que pode ser visto à p. 99. Segundo o próprio autor, o compêndio fora o resultado de mais de vinte anos estudos em Direito Constitucional. A mesma lição pode ser vista em BARBOSA, Rui. Commentários á Constituição Federal Brasileira. São Paulo : Saraiva \& Cia., 1933, p. 477.

${ }^{28}$ Cf. POCOCK. J. G. A. Linguagens do ideário político. São Paulo : Edusp, 2013, p. 282.

${ }^{29}$ Cf. POCOCK. J. G. A. Linguagens do ideário político, cit., p. 282.
} 
poder, o povo ${ }^{30}$. Diante disso, firmou-se a ideia segundo a qual se se trata de soberania do povo desaparece automaticamente a do legislador ordinário, haja vista a impossibilidade de um corpo soberano se submeter a outro ${ }^{31}$. A garantia da subsistência e supremacia da Constituição como é de conhecimento corrente, se dava pela rigidez de seu texto, isto é, pela estipulação de um procedimento mais complexo para alteração de seus dispositivos do que o utilizado para as leis ordinárias, e o próprio judicial review.

É nesse ponto que ocorre uma dissonância entre os constitucionalismos norteamericano e europeu. Neste último, as características da Constituição advindas daquele só se consolidam, efetivamente, do fim da Segunda Guerra Mundial em diante ${ }^{32}$.

No caso francês, por exemplo, a essa altura, a consequência mais direta do movimento revolucionário tinha sido confirmação da supremacia do Parlamento, dada a consagração do modelo representativo. Com efeito, na França, por soberania popular entendia-se apenas o fato de que a Constituição repousava no soberano (povo) e seria legitimada democraticamente por este. A reforma da Constituição dependeria de um processo descrito no próprio texto constitucional. A Assembleia Constituinte de 1789 tinha a convicção de que havia criado um texto duradouro, com a capacidade de evitar uma situação anárquica. Logo, o "pouvoir constituant" deveria utilizar a soberania de uma única vez. Isso pressupunha que o próprio povo renunciasse ao seu poder constituinte e, assim, anulasse sua soberania no "pouvoir constitué". De todo modo, essa seria uma decisão do povo. Tal decisão poderia ser tomada de duas formas: ou mediante a eleição de uma Assembleia constituinte, pela qual o povo autoriza que se decida sobre a Constituição ou a Assembleia Nacional, pouco importando o modo como tenha sido composta. Uma ou outra deveria elaborar um projeto de Constituição e a submeter ao povo que a aprovaria mediante eleição direta. Mas o fato é que, ao final, "a Assembleia Nacional não tinha sido eleita como constituinte nem dispôs sobre seu projeto à aprovação do povo. Em vez disso, ela se viu como representante soberana do povo: em vez soberania popular, soberania do

\footnotetext{
${ }^{30}$ Cf. FIORAVANTI, Maurizio. Stato e Costituzione. Materiali per una storia delle dottrine costituzionali, cit., p. 121.

${ }^{31}$ Cf. CORWIN, Edward. The "Higher Law" background of American Constitution. Indianapolis : Liberty Fund, 2008, p. 84-85.

32 Não se ignora que durante a vigência da Constituição de Weimar, na Alemanha, iniciara-se o desenvolvimento do controle de constitucionalidade europeu. E que o Tribunal Constitucional austríaco, previsto na constituição daquele país de 1920, mas cuja instalação se dera em 1919, teve grande importância nesse sentido. No entanto, somente a partir das constituições do segundo pós-guerra, com a criação de outros Tribunais Constitucionais como o alemão, o italiano e, mais tarde, o espanhol, é que o modelo europeu se consolida e as constituições finalmente ganham ares de normae normarum.
} 
parlamento". ${ }^{33}$

Esse corolário decorreu também da percepção da lei como “expressão da vontade geral"34. Diz o mestre das arcadas que "[n]o Direito Constitucional clássico, a elaboração da lei cabe ao Poder Legislativo, que é, pelo menos parcialmente, de caráter representativo. De fato, a lei, em sua substância, é a expressão da vontade nacional, manifestada pelos representantes, que se identifica com a vontade geral, ou seja, com os imperativos da Razão"35.

Por conseguinte, "se a lei era a expressão da vontade geral e, se o governo deveria ser de leis e não de homens, o órgão responsável pela formação da lei detinha o poder preeminente" ${ }^{36}$. E se o Parlamento representa a vontade da nação (ou de uma vontade parlamentar), ele exerce verdadeira potestade. É irresponsável e incontrolável, mesmo que a Constituição porventura lhe confira deveres de atuação.

Portanto, o corpo legislativo nem mesmo estava sujeito às suas próprias leis, podendo mesmo derrogar as prescrições gerais mesmo a título particular, "sem que se [pudesse] formular contra seus atos nenhum recurso, jurisdicional nem de nenhuma outra classe" ${ }^{, 37}$. Em outras palavras: a soberania do Parlamento, compreendida como potestade do Estado, jamais poderia ser limitada juridicamente por nenhuma outra ${ }^{38}$.

A proeminência do Parlamento já encontrara em John Locke um fervoroso defensor. O filósofo inglês considerava o Poder Legislativo "como poder supremo, ao qual todos devem estar subordinados" ${ }^{, 39}$. A razão disso é conhecida: a lei era o instrumento por excelência para garantir o exercício tanto da liberdade individual quanto da propriedade, direitos advindos do jusnaturalismo e considerados inerente aos homens. Mas, na sua visão, a lei deveria atender, acima de tudo, a uma expectativa de justiça ${ }^{40}$. Por isso, o contrato social não implicava ceder autonomia a um terceiro ente que não seria parte no contrato, mas destinar poder político a um corpo de representantes dos cidadãos, a quem

\footnotetext{
${ }^{33}$ Cf. KRIELE, Martin. Introdução à Teoria do Estado, cit. p. 203 et passim.

${ }^{34}$ Este é o teor do artigo 6 ${ }^{\circ}$, da Declaração Universal dos Direitos do Homem e do Cidadão, de 1789.

${ }^{35}$ Cf. FERREIRA FILHO, Manoel Gonçalves. Do processo legislativo. São Paulo : Saraiva, 2002, p. 70.

${ }^{36}$ Cf. RIZEK JÚNIOR, Rubens Naman. Os Parlamentos frente às inovações do processo legislativo. Dissertação de mestrado. USP, 2001, p. 43.

${ }^{37}$ Cf. CARRÉ DE MALBERG, Raymond. Teoria General del Estado, cit., p. 231.

${ }^{38}$ Cf. CARRÉ DE MALBERG, Raymond. Teoria General del Estado, cit., p. 231.

${ }^{39}$ LOCKE, John. Dois tratados sobre o governo. São Paulo : Martins Fontes, 2005, p. 518.

${ }^{40}$ Cf. FERREIRA FILHO, Manoel Gonçalves. Do processo legislativo, cit, p. 43.
} 
seria atribuído o poder legislativo ${ }^{41}$. A lei deve ser um produto exclusivo do Parlamento. E esse é um ponto relevante em seu pensamento, pois o que garante à lei um aspecto fundamental em termos de legitimidade para a obediência é o consentimento da sociedade $^{42}$.

Como as Constituções oitocentistas europeias eram flexíveis, inexistia na prática uma hierarquia entre lei e Constituição, de modo que a atuação legislativa era plenamente livre não pelo pluralismo democrático, típico das Constituições novecentistas, sobretudo da segunda metade do século, mas pela vigência do conceito de nação e as consequências práticas desse conceito. O legislador é senhor do momento da produção da lei, não se prendendo a quaisquer amarras, ainda que de natureza constitucional. Seu silêncio é, portanto, uma faceta de sua liberdade irrestrita.

País colonizado por europeus e profundamente influenciado pela cultura destes povos (nos mais variados ramos em que isso possa se externar), o Brasil não fugiu a esse modelo de Constituição. A de 1824 refletia perfeitamente o Zeitgeist em voga, haja vista que o artigo 15, VIII e XIX, preconizava que cabia ao Poder Legislativo (a Assembleia Geral), além da conhecida competência de velar na guarda da Constituição, fazer e interpretar as leis.

A posição de José Antônio Pimenta Bueno, o Marquês de São Vicente, corrobora essa afirmação. Ao comentar a respeito da separação entre o Poder Executivo e o Poder Legislativo, ele alertava para o abuso que se configuraria se o primeiro viesse a efetivamente "fazer a lei", através de delegação (o mandato ainda era do tipo imperativo). Ele asseverava que o artigo $15, \S 9^{\circ}$, da Constituição de 1824, atribuía à Assembleia Geral o dever de velar pela guarda da Constituição e que, por isso, ela deveria ser a primeira a dar o exemplo de respeito à lei. No entanto, esse respeito não vigoraria em relação ao teor da lei. Isso fica particularmente claro no seguinte trecho de sua obra:

[d]izia um publicista: 'Qual peut être l'état d'une nation dont la législature est diamétralement contradictoire sur son premier príncipe, la constitucion même?'. Por certo que este pensamento não deve ser aplicado no Brasil, mas por certo que a subdelegação de que tratamos é um grande abuso, e os abusos do poder

\footnotetext{
${ }^{41}$ Cf. LOCKE, John. Dois tratados sobre o governo, cit., p. 503; Conferir ainda: VAZ, Manuel Afonso. Lei e Reserva da Lei, cit., p. 92.

${ }^{42}$ Cf. LOCKE, John. Dois tratados sobre o governo, cit., pp. 503-504.
} 
Legislativo são sem dúvida os mais perigosos, por isso mesmo que seu custoso corretivo pode ser fatal ${ }^{43}$.

À evidência, se se fala de supremacia do Parlamento, a liberdade do legislador não pode encontrar óbices, repise-se, nem mesmo na Constituição. Isso é reforçado pelo próprio positivismo do século XIX, que reduzia o Direito à lei, como se viu. Se criar lei é o mesmo que criar Direito e se aquela se acha em posição de primazia, então naturalmente o legislador não conhece nenhum limite exterior de forma ou conteúdo ${ }^{44}$.

No Brasil, a potestade parlamentar começa a arrefecer e a conhecer os seus estertores no final do século, com a criação da justiça federal, pelo Decreto $n^{\circ} 848$, de 11 de outubro de 1890 e, em seguida, com o advento da Constituição de 1891, que organiza, em seu artigo 59, uma estrutura normativa voltada ao controle de constitucionalidade. Posteriormente, a lei $\mathrm{n}^{\mathrm{o}} 221$, de 20 de novembro de 1894, clarificou os termos desse controle. No art. 13, §10, preconizava que "os juízes e tribunais apreciarão a validade das leis e regulamentos e deixarão de aplicar aos casos ocorrentes as leis manifestamente inconstitucionais e os regulamentos manifestamente incompatíveis com as leis e com a Constituição". Na exposição de motivos daquele decreto, o Presidente Campos Salles afirmara que

"[é] a vontade absoluta das assembléas legislativas que se extingue, nas sociedades modernas, como se hão extinguido as doutrinas do arbitrio soberano do poder executivo. A funcção do liberalismo no passado, diz um eminente pensador inglez, foi oppor um limite ao poder violento dos reis; o dever do liberalismo na epoca actual é oppor um limite ao poder illimitado dos parlamentos." 45

No início do século XX, o recém-criado STF julgara que "à justiça falta competência para nulificar, ou declarar inválida, uma lei, mas ninguém lhe contesta a faculdade, que envolve um dever, de abster-se de applical-a quando mostrar-se inconstitucional"46 ${ }^{\prime 4}$ Interessante, para efeitos históricos, quanto à interpretação conforme, que teria raízes norte-americanas e alemãs, é o seguinte acórdão: “quando outras razões

${ }^{43}$ Cf. BUENO. José Antônio Pimenta, Marquês de São Vicente. Direito Público Brasileiro e a análise da Constituição do Império. São Paulo : Editora 34 (sem data), pp. 99 e 102.

${ }^{44}$ Cf. VAZ, Manuel Afonso. Lei e reserva de lei..., cit, p. 246.

${ }_{45}$ Disponível em http://www2.camara.leg.br/legin/fed/decret/1824-1899/decreto-848-11-outubro-1890499488-norma-pe.html. Acesso em 04/10/2014, às 20:00h.

${ }^{46}$ Acórdão $\mathrm{n}^{\circ}$ 3.715, de 17 de janeiro de 1915, publicado no D.O. de 14/08/1915, extraído da obra de KELLY, Octavio. Manual de jurisprudência federal. $1^{\circ}$ supplemento. Rio de Janeiro : Revista dos Tribunaes, 1917, pp. 174-175. 
existem para a reintegração do direito violado, deve-se abster o Judiciário de entrar na apreciação das que se fundem na inconstitucionalidade das leis ou decretos" ${ }^{\text {, }}$.

O desenvolvimento do controle de constitucionalidade, no entanto, ainda que limitasse a liberdade do legislador quanto ao conteúdo do ato legislado, não era ainda capaz de elidir a conclusão segundo a qual o silêncio do legislador era algo que variava entre o juridicamente necessário (para a restrição mínima dos direitos individuais) e o constitucionalmente irrelevante, pela própria desimportância da Constituição frente à sua liberdade de tomar a decisão de legislar.

\subsubsection{A atividade legislativa no período novecentista: do início do século até a Segunda Guerra Mundial}

A partir da segunda metade do século XIX, o Estado começa a mudar. Do ponto de vista econômico, a "mão invisível do mercado" não logrou "produzir o bem comum" ${ }^{48}$. No Velho Mundo e no capitalismo concorrencial, os efeitos da Revolução Industrial já se faziam sentir na massa operária recém-formada, com o aumento da miséria e as deficientes condições de trabalho. A mecanização da produção tornou possível a produção em larga escala. "Isso trouxe pelo menos duas consequências visíveis: primeira, a produção de milhares de produtos iguais, em tempo curto e por um preço mais acessível, tornando obsoletas as técnicas artesanais de produção. Depois, a decretação de morte dos pequenos produtores"49. Disso decorreu a acumulação do capital e a concentração econômica, o que levou ao fim da concorrência ${ }^{50}$.

De igual modo, a tensão entre proletário e a burguesia aumentou com a popularização das doutrinas socialistas, como o socialismo utópico ${ }^{51}$. Até mesmo a Igreja atentou-se para a questão social e contribuiu para a crítica ao individualismo daqueles tempos. Nas Encíclicas Rerum Novarum, no papado de Leão XIII, de 1891, e na Quadragesimo anno, do papa Pio XI, de 1931, houve a defesa da tese de que o Estado

\footnotetext{
${ }^{47}$ Acórdão no 2.069, de 30 de janeiro de 1913, publicado no D.O. de 13/11/1915. Julgado também extraído de KELLY, Octavio. Manual de jurisprudência federal. $1^{o}$ supplemento. Rio de Janeiro : Revista dos Tribunaes, 1917, pp. 174-175.

${ }^{48}$ Cf. CLÈVE, Clèmerson Merlin. A atividade legislativa do Poder Executivo. São Paulo : Editora Revista dos Tribunais, 2000, p. 37.

${ }^{49}$ Cf. CLEVE,Clèmerson Merlin. Atividade legislativa do Poder Executivo, cit, p. 38.

${ }^{50}$ Cf. GRAU, Eros Roberto. A ordem econômica na Constituição de 1988. São Paulo : Malheiros, 2010, p. 21.

${ }^{51}$ Cf. CHATELÊT, François; DUHAMEL, Olivier; KOUCHNER, Evelyne Pisier. História das ideias politicas. Rio de Janeiro : Zahar, 2009, pp. 130-136.
} 
deveria atuar para proteger os mais pobres, sem se descurar, no entanto, da proteção da propriedade privada $^{52}$.

Não demorou até que o embate ideológico entre burguesia e as camadas populares adentrasse o Parlamento. Com o advento do sufrágio universal, estas podiam eleger seus representantes no intuito de "satisfazer sua legítima aspiração de participar do processo político" ${ }^{53}$.

Isso se refletiu até mesmo na composição das Casas Legislativas e no processo legislativo. Deveras, o modelo de organização até então existente era calcado numa composição homogênea (as eleições eram censitárias, relembre-se). Na Itália, por exemplo, o processo legislativo era levado a efeito pelos gabinetes ou repartições, denominados Uffici. Após a eleição de 1919, a primeira após a adoção do sistema eleitoral proporcional, a composição da Câmara dos Deputados tornou-se muito heterogênea. Formaram-se "verdadeiros grupos político-ideológicos, tais como os populares, os socialistas, os liberais e outros de identificação imprecisa, mas que certamente não se enquadravam nos grupos anteriormente citados" 54 .

No início do século XX, eis o Estado exibindo um perfil intervencionista na ordem econômica e social, nele se incorporando deveres de atuação dos quais até então encontrava-se isento. A ele foi incorporado, também, o dever de propiciar uma vida digna àqueles que não possuíam meios materiais para tanto.

É consenso que a Constituição de Weimar, de 1919 - ao contrário da Constituição mexicana de 1917 , de índole claramente revolucionária ${ }^{55}$ - traduz-se na corporificação mais emblemática do embate político em torno das diversas correntes político-econômicas e a tentativa de acolhê-las todas no texto constitucional ${ }^{56}$. O resultado disso foi a constitucionalização, no Livro II, de direitos sociais e econômicos, que dividiam

\footnotetext{
${ }^{52}$ Cf. PAPA LEÃO XIII. Carta Encíclica Rerum Novarum, sobre a condição dos operários. 1891. Disponível em http://www.vatican.va/holy_father/leo_xiii/encyclicals/documents/hf_l-xiii_enc_15051891_rerumnovarum_po. html. Acesso em 24/05/2014, às 10:00h; PAPA PIO XI. Quadragesimo anno. 1931. Disponível em http://w2.vatican.va/content/pius-xi/pt/encyclicals/documents/hf_p-xi_enc_19310515_quadragesimoanno.html. Acesso em 24/05/2024, às 10:20h.

${ }^{53}$ Cf. LOEWENSTEIN, Karl. Teoria de la Constitución. Barcelona : Editorial Ariel, 1976, p. 399.

${ }^{54}$ Cf. CASSEB, Paulo Adib. Processo Legislativo. Atuação das comissões permanentes e temporárias. São Paulo : Editora Revista dos Tribunais, 2008, pp. 51-52.

${ }^{55}$ Cf. HORTA, Raul Machado. Direito Constitucional. $5^{\text {a }}$ ed. Belo Horizonte : Del Rey Editora, 2010, p. 188.

${ }^{56}$ Cf. HORTA, Raul Machado. Direito Constitucional, cit, p. 190; LOEWENSTEIN, Karl. Teoria de la Constitución, cit, p. 212, para quem a "Constituição de Weimar mesclou com promiscuidade ideologias liberais e socialistas".
} 
espaço com direitos individuais proclamados nas declarações de direitos já conhecidas. Esta Constituição tornava-se o novo modelo a ser seguido ${ }^{57}$.

No Brasil, a influência desse paradigma fez-se sentir na Constituição de 1934. Tal qual na congênere germânica, os direitos vinham elencados na parte final do texto (no caso brasileiro, no Título III a V, à frente somente das disposições relativas à segurança nacional e aos funcionários públicos). Na Constituição de 1937, os direitos individuais e econômico-sociais foram mantidos, ainda que de uma forma mais resumida do que na Constituição anterior. Na Constituição da redemocratização, a de 1946, tal qual a de 1934, houve a previsão de uma pletora de direitos sociais (Títulos IV, V e VI), dispostos depois da estruturação orgânica do Estado.

Afirme-se, no entanto, que nem mesmo sob a vigência dessas Constituições analíticas e prenhes de normas programáticas, a liberdade do legislador fora questionada ou tampouco delas se extraíram deveres a ponto de fomentar uma inconstitucionalidade por omissão. Certo é que Pontes de Miranda já denunciava que a quantidade excessiva de leis e decretos não servia para outra coisa senão para não resolver problemas, para não legislar de fato: "fazer sempre de novo, sem fazer novo" 58.

Quando se compulsam as obras clássicas de controle de constitucionalidade, estas ainda se resumem às comissivas, mesmo se considerassem as normas constitucionais obrigatórias e imperativas. $\mathrm{O}$ abuso da atividade legislativa se dá quando é feita fora dos limites de determinação constitucional ${ }^{59}$. A liberdade de decidir se e quando legislar permanece, pois, intocada. Não fosse isso o suficiente, as Constituições de 1934 e 1937 procuraram constitucionalizar um particular aspecto dessa liberdade, ao consagrar, em seus arts. 68 e 94, respectivamente, que "é vedado ao Poder Judiciário conhecer de questões exclusivamente políticas". Semelhante disposição ainda hoje encontra-se vigente na Itália, conforme se vê do art. 28, da lei $n^{\circ} 87 / 53$.

\footnotetext{
${ }^{57}$ Cf. FERREIRA FILHO, Manoel Gonçalves. Direitos Humanos Fundamentais. $13^{\mathrm{a}}$ ed. São Paulo : Saraiva, 2011, p. 67.

${ }^{58}$ Cf. MIRANDA, Francisco Cavalcanti Pontes de. Comentários à Constituição de 1946. Vol I. $2^{\mathrm{a}}$ ed. São Paulo : Max Limonad, 1953, p. 153.

${ }^{59}$ Cf. BITTENCOURT, Lucio. O controle jurisdicional da constitucionalidade das leis. $2^{\mathrm{a}}$ ed. Rio de Janeiro : Forense, 1968, p. 59 e 72; CAMPOS, Francisco. Direito Constitucional. Rio de Janeiro : Revista Forense, 1942, p. 4. Estes autores, no entanto, faziam menção à inconstitucionalidade da lei pela omissão de formalidades do processo legislativo (para o primeiro, à p. 80; para o segundo, p. 4). Conferir ainda: BUZAID, Alfredo. Da ação direta de declaração de inconstitucionalidade no direito brasileiro. São Paulo : Ediçao Saraiva, 1958, pp. 44 e ss., especialmente a p. 50.
} 


\subsubsection{O caráter executável ou não-executável das normas constitucionais como fundamento para a liberdade do legislador}

Assentou-se no item 1.2.1, que o constitucionalismo oitocentista, do qual o brasileiro não destoava, entendia que a Constituição não devia ostentar uma característica analítica, típica das codificações legislativas. Essa concepção poderia ser sintetizada no seguinte: "as constituições se completam em leis orgânicas", pois "ao legislador cumpre, ordinariamente, revestir-lhes a ossatura delineada, impor-lhes o organismo adequado, e

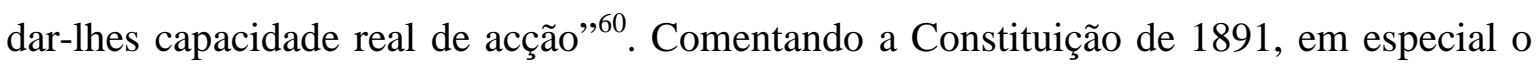
artigo $34^{61}$, Rui Barbosa disse, com todas as letras, que era esse o sentimento da própria Constituinte e, de consequência, da própria Constituição. Disso se pode inferir que era a vontade constituinte deixar ao alvedrio do legislador a tarefa de fechamento das normas constitucionais. E que, quando o constituinte mesmo quis fazê-lo, dispôs de modo completo uma norma, de forma que pudesse ser de pronto executável. De modo geral, a Constituição era aplicada diretamente quanto aos direitos individuais e em relação a normas proibitivas, como aquela que vedava que a pena passasse da pessoa do delinquente ${ }^{62}$.

O fundamento teórico dessa conclusão não é difícil de ser encontrado: é que, na esteira da doutrina constitucional clássica americana, foi adotada a classificação segundo a qual as normas constitucionais ou são auto-executáveis por si mesmas ou não o são (normas self executing ou normas not self executing). Isto é, ou a Constituição designa outra autoridade, indicando um processo especial para tornar uma norma exequível, caso em que seu "uso tem de aguardar (...) a Legislatura, segundo o seu critério",63, ou ela mesma o faz. Sem dúvida alguma, as normas constitucionais continuavam a ser encaradas como normas jurídicas ${ }^{64}$, mas isso não implicava considerar que poderiam, desde logo, ser aplicadas diretamente, como se irradiassem de modo imediato todos os efeitos jurídicos que dela se pudessem esperar. Diga-se, por oportuno, que a classificação de normas conforme o grau de aplicabilidade até hoje informa o estudo do Direito Constitucional, principalmente o brasileiro.

${ }^{60}$ Cf.BARBOSA, Rui. Commentários á Constituição Federal Brasileira, cit., p. 478.

61 Dizia o preceptivo: "Art. 34. Compete privativamente ao Congresso Nacional: 32. regular os casos de extradição entre os Estados; 33. decretar as leis e resoluções necessarias ao exercicio dos poderes que pertencem á União; 34. decretar as leis organicas para a execução completa da Constituição".

${ }^{62}$ Cf. BARBOSA, Rui. Commentários á Constituição Federal Brasileira, cit., p. 478 e ss.

${ }^{63}$ Cf. BARBOSA, Rui. Commentários á Constituição Federal Brasileira, cit., 489.

${ }^{64}$ Isso ficará claro, quando da análise das normas programáticas. 
Foi dito também que nem mesmo nas Constituições brasileiras de 1934, 1937 e 1946, de pendores analíticos e dependentes de atuação da lei ordinária em tantas de suas normas, a liberdade do legislador, quanto à decisão de legislar, foi contestada. Essa assertiva tem razão de ser porque a lição clássica acima referida não perdeu seu valor. Se a doutrina nacional não se opunha ao dilatado espectro de liberdade do legislador, tampouco a jurisprudência do STF daquele período o constrangia.

Mesmo sob os influxos do "novo modelo" das Constituições programáticas, o Tribunal limitava-se a reconhecer que determinada matéria deveria ser objeto de conformação por lei ordinária e, na falta desta, nada se poderia fazer a não ser aguardar-se a iniciativa do Poder Legislativo.

Esse posicionamento é bastante evidente em temas ligados ao Direito do Trabalho, mas com reflexos nos direitos sociais. Assim aconteceu no AI (Agravo de Instrumento) $n^{\circ} 13.375^{65}$. Nesse caso, a justiça trabalhista havia julgado procedente reclamação trabalhista e concedido aumento de adicional noturno a trabalhador de companhia ferroviária. No TST, no entanto, o acórdão da instância inferior foi reformado, sob o fundamento de que o benefício previsto no art. 157 , III $^{66}$, da então vigente Constituição de 1946, não era autoaplicável. Em julgamento do recurso, o STF, pelo voto do Ministro Ribeiro da Costa, relator do recurso, confirmou-o, aduzindo que os preceitos que definem princípios gerais, sem enunciar as garantias de direitos individuais, dependem da lei ordinária para lhe dar aplicação e "enquanto esta não ser dispuser a respeito, há que aguardar a adoção, contendo as regras e as medidas justas aplicáveis”.

Outro caso em que pode servir de ilustração ao que aqui se expõe é o do RE (Recurso Extraordinário) $\mathrm{n}^{\mathrm{o}} 12.049^{67}$. Neste, ainda no campo do Direito do Trabalho, o interessado, uma instituição bancária, buscou reverter acórdão do TST que confirmara decisão da junta trabalhista que havia deferido pedido do reclamante de não ser transferido pelo banco reclamado da matriz à filial em outra cidade. Para tanto, o reclamante invocara a proteção dos arts. 163 e 164 (normas de claro cunho programático), que condicionariam a aplicação do art. 147, da Constituição de $1946^{68}$. Decidiu o STF, no voto do Ministro

\footnotetext{
${ }^{65}$ DJ de 29/09/47.

${ }^{66}$ Dispunha o preceito que "Art. 157. A legislação do trabalho e a da previdência social obedecerão nos seguintes preceitos, além de outros que visem a melhoria da condição dos trabalhadores: III - salário do trabalho noturno superior ao do diurno".

${ }^{67}$ DJ de 10/10/1947.

${ }^{68}$ Os artigos tinham estavam gizados da seguinte forma: "art 163 - A família é constituída pelo casamento de vínculo indissolúvel e terá direito à proteção especial do Estado"; "art 164 - É obrigatória, em todo o
} 
Orosimbo Nonato, que o TST agira com justiça, mas que a questão a ser resolvida não estava em caracterizar a justiça ou injustiça do procedimento da empresa, mas sim em apreciar uma ofensa ao texto constitucional causada pelo próprio tribunal trabalhista, porquanto as normas supracitadas eram apenas normas diretivas que apontavam o caminho para a lei ordinária.

Finalmente, mencionem-se os REs n $19.132^{69}, 14.200^{70}$ e $14.553^{71}$, bem como no $\mathrm{AI}^{\mathrm{o}} 13.781^{72}$. Nestes julgados, o STF enfrentou uma questão atinente ao cabimento do recurso de revista. Segundo o art. 896, da Consolidação das Leis do Trabalho, esse recurso era cabível somente quando (a) "a decisão em última instância der à mesma norma jurídica interpretação diversa, pelo Tribunal Regional ou pelo Tribunal Superior do Trabalho, na plenitude de sua composição, salvo se a decisão recorrida estiver em consonância com prejulgado ou jurisprudência uniforme deste" e (b) "proferidas com violação da norma jurídica". A reclamação versava sobre falta de pagamento de descanso remunerado para pracistas que percebiam seus salários fora da hipótese da lei $n^{\circ} 605 / 49$, porque esta se silenciara quanto à situação esses empregados. Decidiu a Corte que tal recurso não poderia ser conhecido, pois "na proteção dos direitos dos litigantes, impõe-se ao juiz a rigorosa observância dos casos em que o legislador permite o reexame da matéria em grau de recurso. Não pode o juiz, fora da lei, conhecer do recurso, a seu arbítrio. Concedendo-o onde a lei não concede, evidentemente contraria a lei, que não desejou, ou mesmo implicitamente vedou o recurso nas condições apresentadas pelo litigante".

No Recurso em Mandado de Segurança $\mathrm{n}^{\circ} 3.835$, julgado em 18/01/57, o Tribunal, no voto do relator, o Ministro Ari Franco, também negou extensão de aumento de vencimento a policial militar reformado, aduzindo que a lei que concedeu tal aumento só o fez para policiais da ativa e da reserva. Ante a invocação do art. 193, da Constituição de $1946^{73}$, pelo impetrante, o STF considerou o preceito não autoaplicável.

Essa posição perdurou no STF até a Constituição de 1988, praticamente. Em vários acórdãos, o tribunal considerou até mesmo leis não autoaplicáveis, porquanto

território nacional, a assistência à maternidade, à infância e à adolescência. A lei instituirá o amparo de famílias de prole numerosa"; "art. 147 - O uso da propriedade será condicionado ao bem-estar social. A lei poderá, com observância do disposto no art. 141, $\S 16$, promover a justa distribuição da propriedade, com igual oportunidade para todos".

${ }^{69}$ DJ de 07/08/51, relator Ministro Afrânio Costa.

${ }^{70}$ DJ de 21/12/48, relator Ministro Hermes Lima.

${ }^{71}$ DJ de 09/05/49, relator Ministro Ribeiro da Costa

${ }^{72}$ DJ de 25/01/49, relator Ministro Lafayette de Andrada.

73 Dizia o dispositivo: "art. 193 - Os proventos da inatividade serão revistos sempre que, por motivo de alteração do poder aquisitivo da moeda, se modificarem os vencimentos dos funcionários em atividade" 
dependiam de decretos regulamentares para tornarem-se exequíveis ${ }^{74}$.

De todo o exposto, se a soberania do Parlamento não aparece mais na literatura constitucional da primeira metade do século $\mathrm{XX}$, nem por isso a liberdade do legislador quanto à decisão de legislar sofreu ataques contundentes. Nesse aspecto em particular, nada mudou em relação ao período liberal clássico. Há quem afirme que a experiência histórica constitucional brasileira é "uma crônica da distância entre intenção e gesto, do desencontro entre norma e realidade",75, mas há de ser reconhecido que o constitucionalismo brasileiro apenas seguiu a tradição do modo como se pensava a Constituição em cada época.

\subsection{A liberdade de legislar no constitucionalismo democrático}

\subsubsection{Antecedente necessário: a concepção aberta de Constituição}

Se existe algo que a Teoria da Constituição permite concluir - ainda que se $\operatorname{admita}^{76}$ que esta tenha se originado, de forma autêntica, somente a partir da primeira metade do século XX - é que o conceito de Constituição, dada a equivocidade semântica do termo, nunca foi uniforme.

Encontram-se, entre os estudiosos do fenômeno constitucional de ontem e de hoje, concepções diversas ${ }^{77}$, condicionadas pela predominância de elementos que cada qual

\footnotetext{
${ }^{74}$ Caso, por exemplo, do MS no ${ }^{\circ}$ 17.621, DJ de DJ de 07/08/68 (falta de regulamentação de férias de trabalhadores avulsos); 15.931, DJ de 17/10/1966, (falta de regulamentação de regime de trabalho de tempo integral); 15.921, DJ de 13/09/66, (falta de regulamentação de gratificação de tempo integral).

${ }^{75}$ BARROSO, Luis Roberto. O controle de constitucionalidade no direito brasileiro : exposição sistemática da doutrina e análise crítica da jurisprudência. São Paulo : Saraiva, 2004, pp. 192-193.

${ }^{76}$ Assim como faz VERDÚ, Pablo Lucas. Teoría de la Constitución como ciencia cultural. Madri : Dykinson, 1998, pp. 19 e 22. O autor justifica que antes de 1928 não se poderia falar em autêntica Teoria da Constituição porque: a) as especulações sobre a Constituição constavam de escassos capítulos de manuais de direito constitucional, nos quais não havia considerações sobre a sua função e finalidade, ou quando havia, eram tratadas de modo abstrato; b) o positivismo jurídico reinante motivou a exclusão de enfoques extranormativos ou metajurídicos; c) mesmo uma concepção jurídica, como a de Kelsen, não poderia dispensar a realidade; d) toda teoria aponta a uma prática, não devendo, pois, encerrar-se num "egoísmo teórico". Daí a crítica a Kelsen, pois se se nega a realidade, todo o esforço teórico produzido a partir de um método, ainda que se produzam construções admiráveis, chega a ser inútil.

${ }^{77}$ Para uma listagem mais extensa das diversas concepções de Constituição, conferir em: MIRANDA, Jorge. Manual de Direito Constitucional. Tomo II. Coimbra editora, 2007, pp. 66-67; STERN, Klaus. Derecho del Estado de la Republica Federal alemana. Madri : Centro de Estudios Constitucionales, 1987, pp. 204 e ss; OLVERA, Óscar Rodríguez. Teoría de los derechos sociales en la constitución abierta. Granada : Editorial Comares, 1998, pp. 48-89.
} 
reputa como essenciais, seja pela observância das forças atuantes na sociedade (concepção sociológica) ${ }^{78}$, pela decisão política fundamental a ser por ela tomada (concepção decisionista) ${ }^{79}$, pelo exclusivo viés jurídico (concepção jurídica) ${ }^{80} \mathrm{ou}$, ainda, pelo prisma dos valores a serem contemplados pela Constituição (concepção culturalista) ${ }^{81}$. Não se olvide que foram distintas compreensões da Constituição que motivaram uma das mais célebres discussões jurídicas do século $\mathrm{XX}^{82}$.

Esses variados modos de ver o fenômeno constitucional, se tomados isoladamente, talvez não consigam explicar o que é uma Constituição no pluralismo democrático hodierno, como é razoável supor ${ }^{83}$. A harmonização entre a realidade histórico-político-social (o que não exclui a eleição de valores, mas a eles não se limita ou se prende) e a qualidade jurídica é um componente intrínseco de qualquer Constituição que se pretenda "normativa", e não apenas "nominal" ou muito menos "semântica" 84.

Não se pode dar por descontado que as forças políticas jamais se sobrepujarão (ou pelo menos tentarão sobrepujar-se) às normas jurídicas. A política, muitas vezes, obedece a suas próprias regras. Nada obstante, isso também não pode levar à conclusão fatalista segundo a qual a Constituição jurídica sucumba ante a Constituição real, como pensava Lassalle. Concorde-se com Konrad Hesse, também nesses aspectos: aceitar isso significaria negar o caráter normativo do Direito Constitucional enquanto ciência jurídica, restando-lhe somente a função de constatar e comentar os fatos criados pelas relações de poder dominante (Realpolitik) ${ }^{85}$.

\footnotetext{
${ }^{78}$ Essa é a visão de LASSALLE, Ferdinand. O que é uma Constituição? Belo Horizonte : Editora Líder, 2008, p. 63.

${ }^{79}$ Tal é a corrente de SHMITT, Carl. Teoría de la Constitución. Buenos Aires : Editorial Struhart \& Cia (sem data), p. 57.

${ }^{80}$ Cf. KELSEN, Hans. Teoria Pura do Direito. São Paulo : Martins Fontes, 2011, p. 247; BOBBIO, Norberto. Teoria do Ordenamento Jurídico. São Paulo : Edipro, 2011, p. 61.

${ }^{81}$ Cf. HÄBERLE, Peter. Per una dottrina della Costituzione come scienza della cultura. Roma : Carocci, 2001, pp. 28, 33, 35 e 38; VERDÚ, Pablo Lucas. Teorìa de la Constitución como Ciencia Cultural, cit., p. 50. Entre nós: TEIXEIRA, J. H. Meirelles. Curso de Direito Constitucional. Florianópolis : Conceito Editorial, 2011, pp. 76 e ss.

${ }^{82}$ Trata-se da discussão sobre quem deveria ser o guardião da Constituição, havida, como se sabe, entre Carl Shmitt e Hans Kelsen. Por extrapolar os objetivos deste subitem, não cabe aqui descrevê-la. Para uma visão completa desse embate teórico, consultar: SCHMITT, Carl; KELSEN, Hans. La polémica Schmitt/Kelsen sobre la justicia constitucional: El defensor de la Constitución versus ¿Quién debe ser el defensor de la Constitución? Madri : Tecnos, 2009.

${ }^{83}$ Assim: CASTRO, Raquel Alexandra Brízida. As omissões normativas inconstitucionais no direito constitucional português. Coimbra : Almedina, 2012, p. 85.

${ }^{84}$ Como assim as classificou LOEWENSTEIN, Karl. Teoría de la Constitución. Barcelona : Editoral Ariel, 1976, pp. 217 e ss.

${ }^{85}$ Cf. HESSE, Konrad. Temas fundamentais de direito constitucional. São Paulo : Editora Saraiva, 2009, p. 125.
} 
A eficácia da norma constitucional não pode separar-se das condições históricas, naturais, técnicas, econômicas e sociais. Não pode jamais ser ignorado o "substrato espiritual que se consubstancia num determinado povo, isto é, as concepções sociais concretas e o baldrame axiológico que influenciam decisivamente a conformação, o entendimento e a autoridade" das normas ${ }^{86}$.

Mas a Constituição também é lei, é norma jurídica, situa-se também no mundo do dever ser. Daí a justificativa da concepção jurídica de Hans Kelsen. E é por isso que afirma-se que a Constituição é a ordem jurídica fundamental de uma comunidade: ao mesmo tempo em que é conformada pela realidade política e social, procura da mesma maneira conformá-la: “' constituição real' e 'constituição jurídica' estão numa relação de coordenação" ${ }^{87}$. Ao final, Constituição é lei e unidade política do Estado ${ }^{88}$.

Estado e poder estatal não podem ser pressupostos: tornam-se realidade quando há a união de pluralidade de interesses, aspirações e modos de comportar-se. A peculiaridade está em que essa "fusão da pluralidade" nunca está definitivamente concluída: trata-se de processo permanente ${ }^{89}$.

E se há uma característica preponderante nesse processo permanente, essa não é o que se chama "estado de concordância geral", com a supressão das diferenças sociais ou políticas. Recorra-se novamente a Konrad Hesse: a formação daquela unidade tem, como força motriz o conflito, sem o qual não há falar-se em transformações históricas ${ }^{90}$.

À medida que a sociedade avançou, pelo desenvolvimento tecnológico, científico e industrial, pela divisão do trabalho, pelo aumento populacional, etc, as tarefas do Estado aumentaram e se modificaram, conduzindo à sua "pluralização" e “democratização”. A partir do sufrágio universal, o conflito político foi aberto à participação das massas ${ }^{91}$.

Pela complexidade da sociedade e pela qualidade e quantidade das tarefas do Estado, não se pode pretender que a Constituição regule de modo completo e perfeito todas

\footnotetext{
${ }^{86}$ Cf. HESSE, Konrad. Temas fundamentais de direito constitucional, cit., p. 128.

${ }^{87}$ Cf.HESSE. Konrad. Temas fundamentais de direito constitucional, cit., p. 129.

88 Cf.HESSE, Konrad. Elementos de Direito Constitucional da República Federal da Alemanha. Porto Alegre : Sérgio Antônio Fabris editor, 1998, p. 29. Como se vê, à diferença de Carl Schmitt, Konrad Hesse não diz que a unidade política é superior à ordem jurídica.

${ }^{89}$ Cf. HESSE, Konrad. Elementos de Direito Constitucional..., cit., pp. 29-30.

${ }^{90}$ Cf. HESSE, Konrad. Elementos de Direito Constitucional..., cit., passim.

${ }^{91}$ Cf. HESSE, Konrad. Elementos de Direito Constitucional..., cit., pp. 32-33.
} 
as nuances da ordem estatal ${ }^{92}$. Pelo contrário, os oitocentistas já diziam que a permanência da Constituição tem a ver com sua brevidade, devendo ater-se a princípios gerais. A Constituição não pode arvorar-se em pretensões codificadoras. Assim, enquanto algumas relações podem até ser normalizadas em pormenores, outras, entretanto, apenas por "determinações de amplitude material e indeterminação mais ou menos grande, algumas até de maneira nenhuma"93 "Todo o resto é tacitamente pressuposto ou deixado a cargo da configuração ou concretização pela ordem jurídica. Por causa disso, a Constituição, de antemão não propõe a pretensão de uma ausência de lacunas ou até de unidade sistemática"94. Interessante é a colocação segundo a qual a Constituição, na verdade, aspira à incompletude, o que a faz destacar do restante do "cosmo normativo" 95 .

Ainda seguindo as lições de Konrad Hesse, há outros casos em que a própria Constituição sequer submete à normalização jurídica. Normas que tratam de certas matérias, tais como "a constituição econômica", são deixadas conscientemente abertas ${ }^{96}$. Nesses casos, afirma Klaus Stern, a abertura é pensada como um mecanismo utilizado para evitar que se subtraia às forças políticas, ao legislador ordinário e ao governo a margem de manobra necessária para as decisões que são de sua responsabilidade ${ }^{97}$. Por isso mesmo há tempos já se advertiu que

[u]ma Constituição não é, nem pode ser, a pré-moldagem da sociedade civil, mas sim o enunciado de modelos jurídicos abertos capazes de propiciar-lhe meios e modos para superar inevitáveis conflitos econômicos, políticos ou culturais através do livre jogo dos interesses e das ideias, conforme as futuras opções soberanas do eleitorado. Não é, pois, um rol de soluções compulsórias, mas a garantia de soluções a serem livremente alcançadas na concretitude [sic] da experiência social, através do debate crítico dos programas políticos e das aspirações de todas as categorias coletivas. Desse modo, quando o legislador se substitui ao povo, impondo-lhe

\footnotetext{
${ }^{92}$ Assim já se expressou: "una constitución no es una ley social; ella se dirige a la colectividad. No es tarea suya la regulación de las distintas materias, ni puede serlo puesto que debe imponerse una brevedad lapidaria (Cf. FORSTHOFF, Ernst. Concepto y esencia del Estado Social del Derecho. In ABENDROTH, Wolfgang; FORSTHOFF, Ernst; DOEHRING, Karl. El Estado Social. Centro de Estudos Constitucionales, 1986, p. 88). ${ }^{93}$ Cf. HESSE, Konrad. Elementos de Direito Constitucional..., cit., p. 38.

${ }^{94}$ Cf. HESSE, Konrad. Elementos de Direito Constitucional...,, cit., p. 39. Conferir ainda: RODRIGUEZ, Jose Julio Fernandez. La inconstitucionalidad por omisión. Teoria General. Derecho comparado. El caso español. Madri : Editorial Civitas, 1998, p. 126.

${ }^{9}$ Cf. LEONCY, Léo Ferreira. "Princípio da simetria" e argumento analógico. O uso da analogia na resolução de questões federativas sem solução constitucional evidente. Tese. USP, 2011, p. 31. A expressão entre aspas foi retirada pelo autor da obra de CANOTILHO, J J Gomes. Direito Constitucional e Teoria da Constituição. Almedina, 1999, p. 1069, nota 25.

${ }^{96}$ Cf. HESSE, Konrad. Elementos de Direito Constitucional...,, cit., p. 39.

${ }^{97}$ Cf. STERN, Klaus. Derecho del Estado de la Republica Federal alemana, cit., p. 222.
} 
normas rígidas e bloqueando o processo de livre construção de seu próprio caminho, caímos no 'holismo', uma das mais nocivas formas de autoritarismo, e porta aberta ao totalitarismo ${ }^{98}$.

Em virtude disso, se afirmou que a Constituição deve ser "pragmática e não programática", isto é, não deve ser confundida com programas de partidos políticos. Deve, isso sim, expressar anseios realizáveis, contemplando direitos imediata e prontamente fruíveis pela sociedade ${ }^{99}$. A Constituição, então, deve configurar-se como uma lei-quadro, dependente da mediação e concretização pelos seus intérpretes ${ }^{100}$. E,

[s]e a Constituição democrática é uma norma aberta, isso quer dizer que sobre certas matérias o Povo soberano quis que se pronunciassem suas gerações vivas através de seus representantes no órgão legislativo (este é o fundamento da reserva de lei no Estado democrático). É esse último quem deve decidir sobre o modo, intensidade e extensão da introdução do poder público nas relações sociais que corresponda, dentro da margem constitucionalmente imposta; mesmo que tenha a obrigação de decidir se não deseja infringir a Constituição ${ }^{101}$.

${ }^{98}$ Cf. REALE, Miguel. Liberdade e Democracia. Em torno do Anteprojeto da Comissão Provisória de Estudos Constitucionais. São Paulo : Saraiva, 1987, p. 18.

${ }^{99}$ Cf. GRAU, Eros Roberto. A constituinte e a constituição que teremos. São Paulo : Editora Revista dos Tribunais, 1985, pp. 46 e 50-51. Todavia, em escritos posteriores, ele parece ter alterado sua posição a respeito disso, tendo se afeiçoado com a constituição dirigente e às suas "promessas". É o que pode ser visto na Resenha do Prefácio da $2^{\mathrm{a}}$ edição da famosa obra Constituição dirigente e vinculação do legislador, em que o autor reforça o caráter dirigente da Constituição brasileira de 1988, garantindo eficácia normativa àquelas normas programáticas (cuja expressão em si, a seu ver, carrega vícios ideológicos perniciosos, daí por que deveria ser abandonada). E que os inimigos do dirigismo constitucional, que ignoram a vinculação do legislador à Constituição, dão prova cabal de que a doutrina do direito público vai na contramão da evolução da constitucionalização do direito civil (Cf. Resenha do Prefácio da $2^{a}$ edição. In: COUTINHO, Jacinto Nelson de Miranda (org.). Canotilho e a constituição dirigente. Rio de Janeiro : Renovar, 2003; GRAU, Eros Roberto. A ordem econômica na Constituição de 1988., 14ª ed. São Paulo : Malheiros, 2010, pp. 359-373, especificamente, pp. 363 e 366-367).

${ }^{100}$ Cf. CANOTILHO, J J Gomes. Direito Constitucional e Teoria da Constituição. Almedina, 2003, p. 1150, afastando-se de posicionamentos de outros tempos, conforme se pode ver na sua Constituição Dirigente $e$ vinculação do legislador. Contributo para a compreensão das normas constitucionais programáticas. Coimbra: Coimbra editora, 1994, p. 307.

${ }^{101}$ Cf. MENÉNDEZ, Ignacio Villaverde. La inconstitucionalidad por omisión. Madri : McGraw-Hill, 1997, p. 19. Traduzido do original: "Si la Constitución democrática es una norma abierta eso quiere decir que sobre ciertas materias el Pueblo soberano ha querido que se pronuncien sus generaciones vivas a través de sus representantes en el órgano legislativo (este es el fundamento de la reserva de ley en el Estado democrático). Es este último quien debe decidir acerca del modo, intensidad y extensión de la introducción del poder público en las relaciones sociales que corresponda, dentro del margen constitucionalmente impuesto; aunque tenga la obligación de decidir si no desea infringir la Constitución”. Em sentido similar: VERGOTTINI, Giuseppe de. Diritto Costituzional, cit., p. 187: "atualmente si ritiene che la riserva non vada considerata soltanto come una forma di garanzia nei confronti del governo-pubblica amministrazione, ma anche come una forma de vincolo posto dal costituente a carico del legislatore e quindi come l'individuazione di una competenza a legiferare. In altre parole, quando in molteplici sue disponizioni la costituzione prevede che "in base alla lege", "secondo la legge", "in casi e nei modi previsti dalla legge" e simili, saranno adottate certe normative, ciò significa che il parlamento é tenuto a intervenire per dettare le sue discipline, a seconda dei casi più o meno dettagliatamente articolate, e non potrebbe quindi disporre nella sua legislazione 
De todo o exposto, a abertura da Constituição funciona numa dimensão dúplice: do ponto de vista normativo, como um sistema (composto de regras e princípios) incompleto, fragmentário, seja por não ter índole codificadora, ou por simplesmente reconhecer o constituinte que é impossível proceder ao tratamento normativo de todas as questões da vida. Tem-se, assim, uma abertura constitucional do tipo horizontal e apresenta a sua razão de ser para evitar o indesejável perfeccionismo constitucional ${ }^{102}$.

Essa abertura é característica de normas que tratam de matérias: a) sobre as quais há um consenso geral; b) em relação às quais é necessário criar um espaço de conformação política; c) que justificam a tomada de medidas corretivas. É o que se denomina de abertura vertical ${ }^{103}$.

A abertura da ordem constitucional, ao final, é meio de atribuição de estabilidade à Constituição e de participação de representantes das mais diversas correntes políticas na tomada das decisões do Estado e, por isso, na conformação da própria sociedade. Por conseguinte, como mesmo afirma Gustavo Zagrebelsky, a assunção do pluralismo sob a forma de uma constituição democrática "é simplesmente uma proposta de soluções e de coexistências possíveis, ou seja, um 'compromisso das possibilidades', não um projeto rigidamente ordenador, que possa ser assumido como um a priori da política dotado de força própria, de alto a baixo". Mais a frente, completa: "não é a Constituição, mas a política constitucional, que derivará das agregações e distanciamentos do pluralismo, é que poderá determinar os êxitos constitucionais historicamente concretos" ${ }^{\text {104. }}$.

Há que se ter em mente, ademais, que a experiência constitucional põe em relevo que a permanência da Constituição não significa engessamento de seu conteúdo

l'affidamento di una ulteriore disciplina a fonti diverse. Secondo la Corte costituzionale, la riserva implica dunque sia il "monopolio del legislatore", escludendo la concorrenza delle fonti secondarie, sai l'imposizione "alla autorità normativa primaria di non sottrarsi al compito che solo ad essa è affidato (383/1998)".

${ }^{102}$ Cf. CANOtilho, J J Gomes. Direito Constitucional e Teoria da Constituição, cit., pp. 1180 e 1339 ; CANOTILHO, J J Gomes. Constituição Dirigente..., cit, p. 193. A importância dos princípios, em particular, dá-se quanto à abertura a várias possibilidades de concordância, compromissos e conflitos. Além disso, ao referirem-se a valores, possuem uma função "normogenética" e "sistêmica": são o fundamento de regras jurídicas e ainda dão harmonia e coerência ao sistema constitucional. Como sistema aberto, necessita de "processos judiciais, procedimentos legislativos e administrativos, iniciativas dos cidadãos", pelos quais passa de uma "law in the books para uma law in action" ou para uma "living constitution" (Cf. CANOTILHO, J J Gomes. Direito Constitucional...cit, p. 1163).

${ }^{103}$ Cf. CANOTILHO, J J Gomes. Direito Constitucional e Teoria da Constituição, cit., p. 1181.

104 Cf. ZAGREBELSKY, Gustavo. Il diritto mite. Milão : Einaudi, 1992, p. 10. Do original: “(...) è semplicemente una proposta di soluzioni e di coesistenze possibili, cioè, un 'compromesso delle possibilità', non un progetto rigidamente ordinante che possa essere assunto come un a priori della politica dotato di forza propria, dall'alto al basso". Grifo do autor. 
normativo: "a imutabilidade de um texto é função tanto de sua rigidez quanto de sua abertura" ${ }^{105}$. Ao contrário, é graças à flexibilidade do sistema que há maior capacidade de movimentos dos poderes públicos quando da criação de políticas a serem seguidas ${ }^{106}$. Pode-se, então, referendar o vaticínio segundo o qual a concepção aberta de Constituição implica admitir a revogação futura de decisões políticas atuais. E mais:

[o] próprio conteúdo material da Constituição vem parar na definição de um marco puramente abstrato, em cujo seio podem existir, simultânea ou sucessivamente, políticas completamente diferentes. Com a mesma Constituição, pois, são possíveis Leis de conteúdo muito diverso e até antagônico, segundo o partido no poder, e isso não é acidental, mas, justamente, um dos fins primários da própria construção constitucional ${ }^{107}$.

A ordem constitucional aberta significa, em suma, que a Constituição permite sempre uma reinterpretação de si mesma, o que implica considerar que a norma constitucional é dotada de uma considerável capacidade expansiva e receptiva, consequência das dinâmicas política e jurídica, domésticas e internacionais. Assim, a Constituição pode modificar-se sem limites (quantitativos) ${ }^{108}$.

Bem de ver que os conceitos de abertura constitucional e de constitucionalismo dirigente, este ainda tão popular no Brasil, dificilmente se harmonizam. É sabido que J. J. Gomes Canotilho, ao defender que "o direito constitucional é um direito não dispositivo, pelo que não há âmbito de conformação do legislador contra as normas constitucionais nem discricionariedade na não actuação da lei fundamental"109, pretendeu, com sua "teoria de constituição", estabelecer um grau de vinculação tal do legislador que pudesse superar o paradoxo evidenciado entre aquela não disponibilidade e a tarefa do legislador de atualizar e dar concreção ao conteúdo da Constituição.

Ele de fato não nega a importância da abertura constitucional, mas ressalta que

${ }^{105}$ LLORENTE, Francisco Rubio. La forma del Poder. Estudios sobre la Constitución. Madri: Centro de Estudios Constitucionales, v. I. 2012, p. 137.

${ }^{106}$ RODRIGUEZ, Jose Julio Fernandez. La inconstitucionalidad por omisión..., cit., p. 126.

${ }^{107}$ Cf. ENTERRÍA, Gustavo Garcia; FERNÁNDEZ, Tomáz-Ramón. Curso de Derecho Administrativo. Vol I. Navarra : Thomson-Civitas, 2008, p. 128. Do original: “[e]l propio contenido material de la Constitución viene a parar en la definición de un marco puramente abstracto, en cuyo seno han de poder existir, simultánea o sucessivamente, políticas completamente diferentes. Con la misma Constitución, pues, son posibles Leyes de contenido muy diverso y hasta antagónico, según el partido en el poder, y esto no es accidental, sino, justamente, uno de los fines primários de la propia construcción constitucional".

${ }^{108}$ Cf. PANIAGUA, Enrique Linde. Constitución abierta. Madri : Linde Editores, 1991, p. 12.

${ }^{109}$ Cf. CANOTILHO, J. J. Gomes. Constituição Dirigente..., cit, p. 63. 
esta não pode ser elevada à condição de panaceia da teoria da constituição ${ }^{110}$. Nesse sentido, afirma que são compatíveis a liberdade da decisão política e a fixação de linhas materiais de direção política. Ressalta, contudo, que a teoria da Constituição "aberta" deve seguir para uma teoria material temporalmente adequada, sob pena de se defender a perda da legitimidade normativo-constitucional em proveito de uma função de direção fáticopolítica. Com isso ele quer sustentar que o aumento do campo material e programático de uma constituição pode até causar a redução do espaço de conformação política das instancias decisórias. $\mathrm{Na}$ verdade, este seria o preço do próprio fundamento jurídicoconstitucional da política. A Constituição deve fornecer linhas de direção à política ${ }^{111}$.

É nesse ponto em particular que a Constituição dirigente ostenta a sua fragilidade teórica mais evidente. Esse modelo determina que cada norma constitucional é vinculante, isto é, como se todo o texto constitucional fosse uma imposição a ser atendida pelo legislador (à exceção das normas de aplicação direta e as normas-fim, que nada têm a ver com direitos). Assim, as questões relativas ao preenchimento de normas que dependem da atuação legislativa refogem a considerações sobre "discricionariedade" legislativa: trata-se de um problema de cumprimento da Constituição ${ }^{112}$. Por isso, tem razão Gilberto Bercovici quando diz que a Teoria da Constituição dirigente, por bastar-se em si, por confiar que é possível alterar a realidade social somente por dispositivos constitucionais, por ser "autossuficiente", em suma, é uma teoria que ignora a política e o Estado: "é uma Teoria da Constituição sem Teoria do Estado e sem política" ${ }^{\prime 13}$.

Logo, ainda que não seja, em tese, infensa à abertura constitucional, a Constituição Dirigente, por sua natureza, limita deveras a possibilidade de discussão democrática e até o embate entre diversas correntes ideológicas quando apela a um modelo de direção política da sociedade. Esse calcanhar de Aquiles do dirigismo constitucional, que fê-lo ruir teoricamente, foi reconhecido pelo seu "progenitor", no prefácio à segunda edição de sua Constituição Dirigente. Sem "engeitar o filho" (na grafia do próprio autor), ele admitiu que a construção de uma teoria que eleva, ao nível constitucional, o Estado a "homem de direção" implicou o desconhecimento "do alto grau de diferenciação da estatalidade pluralisticamente organizada". Mas, ao mesmo tempo, ignorou "outras formas

\footnotetext{
${ }^{110} \mathrm{Cf}$. CANOTILHO, J J Gomes. Constituição Dirigente..., cit., p. 147.

${ }^{111}$ Cf. CANOTILHO, J. J. Gomes. Constituição Dirigente, ..., cit. p. 152.

112 Cf. BERCOVICI, Gilberto. Constituição e política: uma relação difícil. Lua Nova, São Paulo , n. 61, 2004. Disponível em: <http://www.scielo.br/scielo.php?script=sci_arttext\&pid=S010264452004000100002\&lng=en\&nrm=iso>. Acesso em 20/08/2014, às 15:00h.

${ }^{113}$ Cf. BERCOVICI, Gilberto. Constituição e política: uma relação difícil. Op. cit., p. 13.
} 
de direcção política que vão desde os modelos regulativos típicos da subjetividade, isto é, modelos de autodirecção social estatalmente garantida até aos modelos neocorporativos, passando pelas formas de delegação conducente a regulações descentradas e descentralizadas" ${ }^{\prime 14}$.

Por ter sido considerado um marco teórico importante - pelo menos antes de "morrer" - muitos elementos de sua obra ainda servem para a discussão do papel do legislador na Constituição e os limites a que ele deve estar sujeito. O presente estudo em várias passagens os utilizará. Por outro lado, a Constituição dirigente não pode ser elevada à condição de resposta acabada, a parâmetro definitivo para aferição dessa discussão, uma vez que a liberdade política do legislador é um tema quase estéril para os fins a que a teoria que ela abarca se propõe.

\subsubsection{A atividade legislativa no constitucionalismo pós-Segunda Guerra Mundial}

Superada a tragédia da $2^{\text {a }}$ Guerra Mundial, consolidou-se uma significativa ampliação do campo constitucional, abrangendo, pois, toda a sociedade, e não só o Estado. Servindo como "ordem jurídica fundamental da comunidade", as Constituições advindas após aquele período buscaram reforçar seu vínculo com o legislador. Durante o Estado Liberal, a atitude esperada do legislador, em termos de proteção aos direitos, praticamente, era o de não legislar ${ }^{115}$. No modelo de Estado atual, estruturado pelo constitucionalismo novecentista, a postura passiva não é mais suficiente, pelo menos para algumas matérias.

Há que ser reafirmado que a reserva de lei cumprirá com os objetivos da abertura constitucional (estabilidade da Constituição e participação política) quando houver um ambiente propício para isso. E é no Estado Democrático de Direito, de índole pluralista, que as condições de realização daqueles fins naturalmente se manifestam.

Em termos assaz perfunctórios, mas suficientes para o que se propõe, por Estado Democrático de Direito compreende-se a organização jurídico-política que tem na supremacia constitucional a fonte que lhe dá conformação e confere validade aos seus atos. Nela, o exercício do poder político é limitado pela separação de poderes e pela proteção aos direitos fundamentais e é legitimado por escolhas livres e soberanas do seu titular (o

\footnotetext{
${ }^{114}$ Cf. CANOTILHO, J. J. Gomes. Constituição Dirigente..., cit., p. X. Os grifos são do autor.

${ }^{115}$ Conferir item 1.2.1.
} 
povo), mediante sufrágio universal e segundo processos que garantam o caráter competitivo do acesso aos cargos responsáveis pela tomada de decisões políticas.

Não é desarrazoado vincular a acepção de Estado Democrático de Direito com a de Estado Constitucional. Nesse sentido, J J Gomes Canotilho, assevera que o Estado Constitucional é "mais" do que o Estado de direito. O elemento democrático não foi apenas introduzido para 'travar' o poder, mas pela necessidade de legitimação do mesmo poder. Só o princípio da soberania popular segundo o qual "todo o poder vem do povo" assegura e garante o direito à igual participação na formação democrática da vontade popular. Assim, o princípio da soberania popular concretizado segundo procedimentos juridicamente regulados serve ponto de união entre "Estado de direito" e o "Estado democrático" ${ }^{, 16}$.

Não se olvide que o pluralismo democrático é também expressão (ou consequência) de outro fenômeno que se consolidou no período novecentista: o fim da separação entre Estado e sociedade ${ }^{117}$. Como foi visto acima, dada a evolução da sociedade técnica, também chamada de sociedade industrial ${ }^{118}$, o Estado é chamado para intervir cada vez mais na esfera econômico-social.

Nas democracias constitucionais novecentistas, aumenta o plexo de novas competências estatais, em que avulta o dever de propiciar uma vida digna àqueles que não possuíam meios materiais para tanto. Assim, angariam particular importância os encargos relativos às prestações positivas, alçados à categoria de direitos: os direitos econômicosociais. Mas os encargos estatais extrapolam a proteção a esses direitos. O Estado também deve ser responsável pela redistribuição de riquezas. Não deve, pois, tão-somente assegurar o funcionamento do processo econômico, mas configurá-lo, de modo que exista uma relação adequada entre salários e preços. Logo, a política econômica é, também, política social $^{119}$.

\footnotetext{
${ }^{116}$ Cf. CANOTILHO, J J GOMES. Direito Constitucional..., cit, p. 100. Os grifos são do autor. Nesse conceito, democracia e constitucionalismo aparecem como noções harmonizadas. Entretanto, nem sempre foi assim. Sobre a difícil convivência entre ambas, principalmente no século XIX, consultar: FIORAVANTI, Maurizio. Percorsi della storia e tendenze attuali. Editori Laterza, 2009, pp. 40 e 47 e ss.

${ }^{117}$ Cf. BERCOVICI, Gilberto. A Constituição Dirigente e a Crise da Teoria da Constituição. In: SOUZA NETO, Cláudio Pereira; BERCOVICI, Gilberto; MORAES FILHO, José Filomeno; LIMA, Martonio Mont'alverne Barreto. Teoria da Constituição. Estudos sobre o lugar da Constituição no Direito Constitucional. Rio de Janeiro : Lumen Juris, 2003, p. 103.

${ }_{118}$ Cf. FORSTHOFF, Ernst. Lo stato della società industriale. Milão : Giuffrè, 2011, p. 22.

${ }^{119}$ Cf. FORSTHOFF, Ernst. Problemas constitucionales del Estado Social. In: ABENDROTH, Wolfgang; FORSTHOFF, Ernst; DOEHRING, Karl. El Estado Social, cit, p. 49.
} 
Na democracia de massa (Massendemokratie), entendida como um processo da formação da vontade estatal pelos diversos grupos com interesses e ideologias diversos (isso quando não conflitantes), a Constituição não é mais somente o locus de defesa de direitos individuais de inspiração jusnaturalista ou da mera organização da estrutura do Estado. Converte-se em fórmula que vincula o Estado e dá conformação à própria sociedade, em seus mais variados aspectos. A Constituição, nessa nova função, contempla uma "reserva material", abarcada por uma Teoria Material de Constituição, na qual alguns autores buscam ver também uma teoria social ${ }^{120}$.

Diante das novas atribuições do legislador, a sua relação com a Constituição ganha novos contornos. Quanto a esse aspecto específico, interessa aqui trazer a lume a posição de Gustavo Zagrebelsky sobre a questão relativa ao "lugar do legislador no Estado Constitucional". Isto é, se ele continua, ainda que em parte, com a plena liberdade oitocentista de determinação (a que ele chama de "legalismo") ou se a legislação tornou-se simples atuação dos direitos e da justiça (o que ele denomina de "constitucionalismo").

A resposta para esse problema depende, inicialmente, da definição da característica da Constituição como um "quadro aberto" de princípios, cuja combinação fique a cargo dos acontecimentos políticos sucessivos, ou como uma "ordem fechada" de valores hierarquicamente estruturados. Contudo, reputa que isso ainda não é suficiente. Há que se levar em conta também outros aspectos fundamentais sobre a estrutura constitucional, em particular a relação entre a legislação e jurisdição.

No "constitucionalismo", a legislação é envolta por uma "rede de vínculos jurídicos”. Nesse caso, a Constituição é um programa positivado de valores que devem ser realizados pela lei. Se assim é, aos juízes (mormente aos juízes constitucionais) é atribuída a função de fazer valer aqueles vínculos em relação ao legislador. No "legalismo", a Constituição revela-se tão-somente num caráter orientativo. À Constituição é reservado apenas um vínculo negativo: basta que o legislador não a desrespeite. Por conseguinte, o papel dos juízes é sensivelmente diminuído, uma vez que haverá de ser reconhecido aquele amplo âmbito de liberdade do legislador ${ }^{121}$.

\footnotetext{
${ }^{120}$ Cf. BERCOVICI, Gilberto. Constituição e política: uma relação difícil. Lua Nova, São Paulo , n. 61, 2004 . Disponível em <http://www.scielo.br/scielo.php?script=sci_arttext\&pid=S010264452004000100002\&lng=pt\&nrm=iso > . acesso em 11 de junho de 2014. http://dx.doi.org/10.1590/S010264452004000100002. No Brasil, como se sabe, J J GOMES CANOTILHO é o mais conhecido deles, pois para ele a Constituição converte-se em instrumento de direção social “calculável” (Cf. CANOTILHO, J.J. Gomes. Constituição Dirigente..., pp. 48, 156 e 170).

${ }^{121}$ Cf. ZAGREBELSKY, Gustavo. Il diritto mite, cit, pp. 208-209.
} 
Ele destaca, então, que a atual concepção constitucional europeia (que não se diferencia da atual Constituição brasileira, acrescente-se) se situa num meio termo entre a prevalência da lei e o domínio da jurisdição (para o primeiro caso, exemplifica com a tradição francesa; no segundo, com a constituição americana). Isso quer dizer que os direitos e a lei haurem o seu valor jurídico e a sua existência a partir da Constituição. Mas, direitos e leis possuem dignidade constitucional própria: a lei não existe em função dos direitos individuais. Pode versar sobre outros interesses públicos não conexos àqueles direitos $^{122}$. Ou por suas próprias palavras: "seria, por essa razão, reduzida, além de fundamentalmente estranha à tradição do pensamento constitucional europeu, uma visão do Estado como simples servidor ou meio técnico da soma dos direitos individuais"123.

A retidão desse pensamento culmina com o fato de que a lei é expressão de direitos políticos que estão situados no mesmo patamar de outros direitos e princípios de justiça. Em casos de contradição, é a lei que deve ceder. Nada obstante, "isso não autoriza de modo algum a negar à legislação a sua originariedade e a sua espontaneidade, isto é, a 'despolitiza-la', degradando-a a uma mera função técnica a serviço da atuação dos conteúdos constitucionais, por mais que esses possam ser considerados fascinantes"124.

Portanto, na contemporaneidade, ao ser adotado a lição acima exposta, resulta claro que a lei ainda é, ou pelo menos deveria ser, (a) realização da política; (b) meio de proteção e conformação de direitos e diversos institutos previstos nos âmbito constitucional; e (c) instrumento auxiliar da Constituição no cumprimento da "missão" de dar configuração à sociedade. De consequência, a função da lei migra de uma posição unicamente garantista contra o Estado para outra relacionada à Constituição e à conformação do Estado e da sociedade, isto é, "de uma legislação jusracionalisticamente inspirada ou dogmatizada passa-se para uma legislação 'social-reformística', 'socialtecnológica' e 'social-informática",125.

Assim, a função legislativa no Estado Constitucional democrático é de dar densidade à norma constitucional, de concretizar o seu conteúdo. Dessa forma, o

\footnotetext{
${ }^{122}$ Cf. ZAGREBELSKY, Gustavo. Il diritto mite, cit, pp. 74-75.

${ }^{123}$ Cf. ZAGREBELSKY, Gustavo. Il diritto mite, p. 76. No original: "sarebbe perciò riduttiva, oltre che fondamentalmente estranea alla tradizione del pensiero costituzionale europeo, una visione dello Stato come símplice servitore o mezzo tecnico della somma dei diritti individuali”.

${ }^{124}$ Cf. ZAGREBELSKY, Gustavo. Il diritto mite, cit, p. 210. No original: "questo non autorizza affatto a negare alla legislazione la sua originarietà e la sua spontaneità, cioè a 'spoliticizzarla', degradandola a mera funzione tecnica servente l'attuazione dei contenuti costituzionali, per quanto essi possano essere elevati e seducenti".

${ }^{125}$ Cf. VAZ, Manuel Afonso. Lei e reserva da lei..., cit., p. 288.
} 
legislador, dentro de marcos estabelecidos pelas normas constitucionais, possui ampla liberdade de atuação ${ }^{126}$. A esse poder de preencher o conteúdo das normas constitucionais, o Tribunal Constitucional alemão cunhou a expressão "liberdade de conformação do legislador" (Gestaltungsfreiheit des Gesetzgebers).

Por conseguinte, a lei não pode (ou pelo menos não poderia) ser subjugada à mera função de execução da norma constitucional ${ }^{127}$. Entender o contrário seria negar que a abertura constitucional significa também aceitar a ideia de que Constituição (ou o constituinte) reconhece que a sociedade é permeada por diferentes visões de mundo, pluralista. E que para se tornar algo vivo e estável deve possibilitar a formação de alternativas aos conflitos e dissensões, ou mesmo a correção de decisões tomadas anteriormente.

Ao proceder à modificação e à inovação do ordenamento jurídico, a legislação também acaba por regular diferentes situações da vida social cujos fins são influenciados segundo a conveniência e utilidade de cada momento histórico. Como atividade marcadamente inovadora, é da própria essência da legislação ser livre e aberta ${ }^{128}$.

Sim, pois se se admite que há diversas possibilidades de se contemplar a vontade da Constituição (ou do poder constituinte, ou, em última análise, do povo, titular do poder), "ninguém pode suplantar nem compelir a vontade do legislador em uma outra direção, se precisamente é o único competente para dar concreção àquelas múltiplas opções" ${ }^{\prime 29}$.

\footnotetext{
${ }^{126}$ Cf. STERN, Klaus. Derecho del Estado de la Republica Federal alemana, cit, p. 224.

${ }^{127}$ Aponte-se aqui o pensamento de Cf. CANOTILHO, J J Gomes. Constituição Dirigente..., cit, p. 30: “[r]eduzir a problemática jurídico-constitucional da 'actualização' e 'execução' do 'bloco diretivo' da lei fundamental ao controlo de inconstitucionalidades (por omissão e por acção) significa erguer o direito constitucional sobre os esquemas das teorias coactivas ou imperativísticas e esquecer uma das suas mais importantes dimensões positivas: impulso, incentivo e direção do processo social. Função importante, mesmo que não haja sanção (no sentido imperativístico) ou esta se encontre submersa no campo de "luta por posições constitucionais". O que pode ser aqui objetado é até onde pode ir esse "processo social". Pelo menos no âmbito da Constituição brasileira de 1988, a opção do socialismo não foi acolhida. E, em Portugal, abandonada, pela reforma constitucional de 1982. Nesse sentido, FERREIRA FILHO, Manoel Gonçalves. Comentário à Constituição Federal de 1988, cit, p. 18; SILVA, José Afonso da. O Estado Democrático de Direito. Revista da Procuradoria Geral do Estado. São Paulo : Centro de Estudos, nº 30, dez. 1988, p. 70. Este autor, no entanto, destaca que a Constituição de 1988 abre perspectivas para profunda transformação social, tanto pelos direitos sociais que prescreve quanto pelos instrumentos postos à disposição da cidadania para concretizar as exigências de um Estado de justiça social fundado na dignidade da pessoa humana.

${ }^{128}$ É essa a lição de ENTERRIA, Gustavo Garcia; FERNÀNDEZ, Tomáz-Ramón. Curso de Derecho Administrativo. Vol I. Navarra: Thomson-Civitas, 2008, p. 129.

${ }^{129}$ Cf. MENÉNDEZ, Ignacio Villaverde. La inconstitucionalidad por omisíon, cit., p. 20. Traduzido do original: "nadie puede suplantar ni compeler la voluntad del legislador en una u otra dirección si precisamente es él el único competente para concretar aquellas múltiples opciones".
} 


\subsection{A Liberdade de legislar na atualidade}

Se, nas democracias constitucionais, a atividade do legislador não pode (ou não poderia) ser comparada a de um mero "detalhamento" da Constituição, convém então afirmar que ele é livre para tomar as suas decisões políticas no intuito de observar as normas constitucionais. Isso naturalmente implica aceitar seu silêncio como escolha política. Mas, em tempos hodiernos, o legislador sempre pode decidir se legisla ou não, ou pelo menos quando fazê-lo?

Está claro que em consonância com a concepção aberta de Constituição, o legislador haveria que possuir, principalmente para aquelas normas "estruturalmente aproximadas de "cláusulas gerais",130, amplo domínio político para proceder às comparações, valorações e ponderações dos fins constitucionais e, a partir daí, tomar decisões politicamente inovadoras.

Mas isso não mais quer dizer que goze de absoluta liberdade de quando (ou se) tomar a decisão de legislar, como, afinal, ocorreu em todas as Constituições brasileiras anteriores à de 1988.

J. J. Gomes Canotilho, ao tratar das dimensões do princípio da constitucionalidade e, dentro dele, o que ele denominou de qualificação dos interesses públicos pelo legislador (o que não passa de um poder de inserir poder público nos espaços vazios constitucionais), faz alusão a uma escala em que a liberdade de conformação é inversamente proporcional à vinculação do legislador à Constituição.

Deste modo, nos casos em que o próprio constituinte definiu o conteúdo de uma norma, o legislador não terá liberdade de "qualificar criativamente os interesses públicos”. A sua função é de concretizar tais interesses. O legislador exerce um poder, de modo determinado e dentro de limites bastante estreitos. Limita-se a "fazer valer" um interesse já definido pela Constituição ${ }^{131}$.

Liberdade de atuação um pouco mais abrangente é o que ele chama de "competência de qualificação legislativa positivamente vinculada". Nesse caso, o legislador pode até qualificar, isto é, dispor sobre certos interesses, mas ainda de modo bem restrito: "só no caso de interesses 'absolutamente prevalecentes' da comunidade se

\footnotetext{
${ }^{130}$ Cf. CANOTILHO, J. J. Gomes. Constituição Dirigente..., cit, p. 218.

${ }^{131}$ CANOTILHO, J. J. Gomes. Constituição Dirigente..., cit, pp. 252-253.
} 
pode, por exemplo, limitar os direitos fundamentais". O problema é que o próprio autor lusitano reconhece a noção vaga desses interesses absolutamente prevalecentes, o que pode justificar "desvios legislativos". Por isso é que para evitar esses tipos de desvios, os interesses devem extraídos diretamente da Constituição e não definidos abstratamente, "ao sabor das constelações políticas no poder" ${ }^{132}$.

Esse é o âmbito denominado de reserva relativa de Constituição, em que a norma constitucional é exequível, mas pode sofrer intervenções legislativas. Em se tratando de normas preceptivas exequíveis por si mesmas, de fato a Constituição retira do legislador a possibilidade de conformá-la, pelo óbvio motivo de que não há o que ser preenchido para fins conferir-lhe eficácia. A decisão para tanto foi tomada no patamar constitucional. A possível conformação a ser levada a cabo pelo legislador diz mais com a regulamentação do preceito constitucional no afã de meramente dar-lhe boa execução ${ }^{133}$.

O que está ao alcance do legislador, e isso se a Constituição autorizar, é a redução da eficácia da norma, pela emanação de lei restritiva. Na Constituição brasileira, o artigo $5^{\circ}$ apresenta muitos exemplos do que aqui se está a falar: incisos VI e VIII (liberdade de crença), XIII (liberdade de exercício de profissão), XV (liberdade de locomoção), XXVII (direitos autorais), XXX (direito de herança), etc.

O legislador terá maior poder de decisão quando for apenas negativamente vinculado à Constituição. Aqui, a sua liberdade de qualificação dos interesses públicos só será questionada se for contrária à ordem constitucional.

Finalmente, para a "competência de qualificação legislativa não arbitrária”, a liberdade de conformação será ainda mais abrangente do que no caso anterior. O legislador pode erigir certos fins políticos que se lhe afiguram oportunos em interesses públicos. $\mathrm{O}$ limite disso é a proibição do arbítrio. Seria o caso das relações internacionais ${ }^{134}$.

Por essa escala, portanto, “a 'força determinante' oscila entre uma espécie de 'grau zero' de vinculação positiva e uma 'heteronomia determinante', estreitamente vinculativa dos atos legislativos". Por determinante heterônoma entende-se algum elemento alheio ao legislador (ou ao administrador) que se lhe impõe. É claro que, para J J

\footnotetext{
${ }^{132}$ CANOTILHO, J J Gomes. Constituição Dirigente..., cit., pp. 253-254.

${ }^{133}$ VAZ, Manuel Afonso. Lei e reserva de lei... cit, p. 312. É o que o autor denomina de conformação extrínseca, em que o legislador exerce a função de intérprete da Constituição.

${ }^{134}$ Cf.CANOTILHO, J J Gomes. Constituição Dirigente..., cit, pp. 254.
} 
Gomes Canotilho, tal determinante é a própria norma constitucional que dirige a atividade do legislador ${ }^{135}$.

Essa graduação é importante não para justificar a constituição dirigente, o que já foi rechaçado, mas para que se perceba que a amplitude de liberdade do legislador pode sofrer variações mais ou menos intensas, principalmente em função de delineamentos feitos pelo próprio texto constitucional, em função da estrutura da norma constitucional e da matéria por ela tratada.

Esse raciocínio vale, portanto, para o estabelecimento de hipóteses em que ele pode se calar e para os casos em que é obrigado a agir. Assim, a sua intervenção poderá ser vedada, exigida ou simplesmente tolerada ${ }^{136}$, sendo que, neste último caso o seu silêncio também haverá que ser tomado como comportamento aceitável. Por conseguinte, à medida que a intervenção do legislador passa de tolerada para exigida, naturalmente aumenta a sua vinculação em relação à Constituição, diminuindo, portanto, a sua liberdade de conformação.

E é claro que, a depender do grau de vinculação do legislador, o seu silêncio pode não mais ser considerado como aceito pela Lei Maior, convolando-se, consequentemente, numa omissão inconstitucional. E é este o tema do próximo capítulo.

${ }^{135}$ Cf. CANOTILHO, J J Gomes. Constituição Dirigente..., cit, pp. 246, o que recai na fragilidade teórica já apontada supra.

${ }^{136}$ Cf. RAMOS, Elival da Silva. Ativismo judicial. Parâmetros dogmáticos. São Paulo : Saraiva, 2010, p. 180. 


\section{A OMISSÃO INCONSTITUCIONAL}

\subsection{A construção do conceito de omissão inconstitucional}

\subsubsection{A natureza da vinculação do legislador à Constituição}

Atualmente, não há dúvidas quanto à normatividade (pelo menos teórica) da Constituição e à sua posição de superioridade em relação ao restante do ordenamento jurídico. Que, por isso, ela subordina os demais poderes públicos a seus termos, inclusive o legislador, também é ponto pacífico. Disso trataram os federalistas ${ }^{137}$, quando das discussões sobre a adoção da Constituição americana e, logo depois deles, Marshall, em 1803, em Marbury v. Madison. Com efeito, respondida a questão se existe ou não subordinação, "é o alcance dessa subordinação o objeto das reflexões contemporâneas sobre a relação entre Constituição e a lei, e, em suma, entre a Constituição e o legislador" ${ }^{\prime 138}$.

Decantada a malsucedida experiência constitucional anterior, a Lei Fundamental de Bonn, de 1949, reservou aos direitos fundamentais importância transcendental. De início, proclamou a Alemanha um "Estado federal, democrático e social" (artigo 20, 1). Em consagração à Teoria Material da Constituição ${ }^{139}$ (o que foi confirmado por diversos julgados do Tribunal Constitucional daquele país), há a previsão, em seus artigos 1.3 e 20.3, que "os direitos fundamentais discriminados a seguir, constituem direitos diretamente aplicáveis e vinculam os poderes legislativo, executivo e judiciário" e "o poder legislativo está submetido à ordem constitucional; os poderes executivo e judiciário obedecem à lei e ao direito".

Comandos dessa estirpe replicaram-se em outros países. Destacam-se, nessa seara, Portugal e Espanha. A despeito de não terem sido devastados diretamente pelos

\footnotetext{
${ }^{137}$ Cf. HAMILTON, Alexander; JAY, John; MADISON, James. O federalista. São Paulo : Russell Editores, 2010. pp. 477-483 e pp. 495-503. Trata-se dos números 78 e 81.

${ }^{138}$ Cf. MENÉNDEZ, Ignacio Villaverde. La inconstitucionalidad por omisión. McGraw-Hill, 1997, p. 2. Traduzido do original: "es el alcance de esa subordinación el objeto de las reflexiones contemporâneas sobre la a relación entre la Constitución y la ley, y, en definitiva, entre la Constitución y el legislador". Em sentido conforme: CASTRO, Raquel Alexandra Brízida. As omissões normativas inconstitucionais no direito constitucional português, cit., p. 80.

${ }^{139}$ Cf. BONAVIDES, Paulo. Curso de Direito Constitucional. 26a ed. São Paulo : Malheiros editores, 2011, pp. 100-101.
} 
horrores do segundo conflito mundial ${ }^{140}$, esses países vinham da queda de longos períodos de governos não democráticos. Assim, a Constituição portuguesa, de 1976, dispõe que é tarefa fundamental do Estado garantir "os direitos e liberdades fundamentais e o respeito pelos princípios do Estado de direito democrático" (artigo 9, "b"). No artigo 18\%, I, determina que "os preceitos constitucionais respeitantes aos direitos, liberdades e garantias são directamente aplicáveis e vinculam as entidades públicas e privadas”.

Por seu turno, a Constituição espanhola, de 1978, prescreve, em seu artigo 53.1 que "os direitos e as liberdades estabelecidos no Capítulo II do presente Título obrigatórias para todas as entidades públicas" e que "somente por lei, que em qualquer caso, deve respeitar o seu conteúdo essencial, pode regular o exercício dos direitos e liberdades, que são protegidas em conformidade com as disposições do artigo 161, 1, a)".

No Brasil, o dispositivo que mais se aproxima dos que foram acima transcritos é o $\S 1^{\circ}$, do art. $5^{\circ}$, da Constituição de 1988 , que, ao preconizar que "as normas definidoras dos direitos e garantias fundamentais têm aplicação imediata", não chega a estabelecer uma vinculação expressa do legislador, tal como ocorreu nos outros modelos de Constituição. Nada obstante, conquanto não haja unanimidade em relação ao alcance desse dispositivo, é tido (equivocadamente, obtempere-se) por parcela da doutrina nacional dos direitos fundamentais como o preceito que consagra a aplicação plena e irrestrita de toda norma que cria um direito, obrigando o Estado a aplicá-las de pronto, pouco importando se necessita de atuação legislativa para densificar-lhe o conteúdo ou não ${ }^{141}$.

Vê-se, portanto, que a expressa vinculação do legislador entra no mundo das Constituições pelas portas dos direitos fundamentais. Diz-se que, a partir daquele pioneiro artigo da precursora Lei Fundamental de Bonn, as normas constitucionais perderam o caráter programático que desde a Constituição de Weimar ostentavam. E que fixaram, portanto, "expressamente a força de obrigar imediata e irrenunciável dos princípios constitucionais e em particular os direitos fundamentais" ${ }^{\prime 42}$. A partir deles, teriam irradiado para outras matérias do texto constitucional, de modo que a doutrina e jurisprudência, em

\footnotetext{
${ }^{140}$ Por óbvio, não se olvide a Guerra Civil espanhola de 1939.

${ }^{141}$ Por exemplo: GRAU, Eros Roberto. A ordem econômica na Constituição de 1988. 10 a ed. São Paulo : Malheiros editores, 2005, p. 326, ainda que este reconheça que o preceito não confere efetividade material e eficácia, isto é, não garante que as decisões do Poder Judiciário sejam executadas pelos seus destinatários.

${ }^{142}$ Cf. STERN, Klaus. Derecho del Estado de la Republica Federal Alemana, cit, p. 371. Traduzido do seguinte: “(...) han fijado expressamente la fuerza de obligar imediata e irrencunciable de los princípios constitucionales y en particular de los derechos fundamentales".
} 
uníssono, confirmaram a existência de mandamentos ${ }^{143}$ ou encargos do legislador, como será visto adiante.

A garantir essa vinculação, além da natural rigidez da norma constitucional, seria atuação da jurisdição constitucional. Não é o caso de descrever todo o processo de escolha do modelo europeu, bem como de suas características, que, ao lado do modelo americano, tanto influenciou a jurisdição constitucional brasileira. Cumpre tão-somente consignar que os Tribunais Constitucionais, a partir do período aqui analisado, desenvolveram uma série de mecanismos decisórios para controlar a atividade legislativa sem precedentes em tempos anteriores. Isso será evidenciado ao longo do trabalho. No âmbito da Constituição brasileira de 1988, para "garantir a efetividade" de normas constitucionais, sobretudo as que tratam de direitos, a liberdade do legislador em relação ao momento de decidir quando legislar (ou se legislar), foi expressamente limitada por dois instrumentos processuais específicos: o mandado de injunção (art. 5º LXXI) e a declaração de inconstitucionalidade por omissão (art. 103, §2º, que, posteriormente, foi "regulamentada" pela lei $\mathrm{n}^{\circ} 9.868 / 99$, nos arts. 12-A a 12-H, incluídos pela lei $\mathrm{n}^{\circ}$ 12.063/09.

A afirmação de que o legislador pratica uma inconstitucionalidade pelo que não faz só foi possível a partir do momento em que se entendeu que da Constituição se extraem deveres ou obrigações que devam ser por ele cumpridos. E isso pressupõe, obviamente, o estabelecimento de uma relação de vinculatividade entre um e outro que vá além da tradicional subordinação "negativa", compreendida como limite material e formal à atuação do Poder Público.

Afirmar que há vinculação jurídica consagra uma obviedade, afinal, a Constituição é norma normarum do ordenamento jurídico, exibindo o status de superlegalidade material e de superlegalidade formal ${ }^{144}$. Pergunte-se, contudo, se as consequências desse liame haverão de ser sempre igualmente jurídicas, ou melhor, jurisdicionais. Ou ainda: por serem normas jurídicas, é correto estabelecer que todas as normas constitucionais dependentes de interposição legislativa convertem-se em fontes de imposições apreciáveis pelo Poder Judiciário? Da vinculação jurídica podem nascer

\footnotetext{
${ }^{143}$ Verifica-se em algumas obras nacionais, a utilização em português da palavra "mandato" para se referir aos deveres de legislar. Essa é um prática equivocada, uma vez que mandato no direito brasileiro significa representação, e não ordem ou dever.

${ }^{144}$ Cf. CANOTILHO, J. J. Gomes. Direito Constitucional e Teoria da Constituição, p. 890; ENTERRÍA, Eduardo Garcia. La Constitucion como norma y el Tribunal Constitucional, p. 50.
} 
corolários ou soluções de natureza política, o que implicaria a interdição do uso de instrumentos e mecanismos jurisdicionais? Em última análise, de normas constitucionais não poderiam nascer uma vinculação também política, e, talvez, em certos casos, até mais intensa que a vinculação jurídica?

Um dos autores que mais influenciaram o Direito Constitucional brasileiro, como se sabe, dentro de sua concepção dirigente de Constituição, deu respostas a essas questões, aduzindo textualmente que "a vinculação constitucional é uma vinculação através da fundamentação e não através de simples limites. (...)”. E isso "[I]mplica a determinação positiva dos actos legislativos pelas normas constitucionais" ${ }^{145}$. Cumpre observar que o autor dá uma "gradação" à "força determinante" da Constituição, que pode variar desde um "grau zero" de vinculatividade positiva até uma "heteronomia determinante" estreitamente vinculativa, como, a propósito, já foi adiantado no final do capítulo 1. No primeiro caso, se a legislação não é inteiramente livre, tampouco é simples discricionariedade (ressalte-se que o autor entende como discricionariedade algo limitado que pode ser objeto de algum controle). No segundo, transparece a ideia de direção da atividade legislativa, pela forte vinculação positiva com a norma constitucional ${ }^{146}$.

Naturalmente, a sua construção teórica parte da definição de imposições constitucionais, entendidas como ordens emanadas pela Constituição ao legislador, haja vista não serem autoaplicáveis. Essas imposições se destinam, segundo sua ótica, (a) à conformação jurídica de situações de fato; (b) à regulamentação de questões específicas; (c) à "criação de pressupostos necessários para a nova evolução do regime constitucional"; (d) à adaptação de leis antigas aos novos princípios constitucionais ${ }^{147}$.

Nesse sentido, afirma que o legislador está normativo-constitucionalmente obrigado a realizar os preceitos constitucionais que necessitem de concretização legislativa, "sendo importante debater-se o meio de evitar que ele protele essas tarefas para as 'calendas gregas'; ao mesmo tempo, porém deve perguntar-se como é que ele cumpre a missão constitucional" "148. Defende, assim, que normas "programático-impositivas" vinculam juridicamente a atividade do legislador na escolha de fins ${ }^{149}$, desde que sejam

\footnotetext{
${ }^{145}$ Cf. CANOTILHO, J. J. Gomes. Constituição dirigente e vinculação do legislador, cit., p. 249.

${ }^{146}$ Cf. CANOTILHO, J. J. Gomes. Constituição dirigente e vinculação do legislador, cit., p. 251.

${ }^{147}$ Cf. CANOTILHO, J. J. Gomes. Constituição Dirigente..., cit., p. 298.

148 Cf. CANOTILHO, J. J. Gomes. Constituição Dirigente..., cit., pp. 256 e 316.

${ }^{149}$ Cf. CANOTILHO, J. J. Gomes. Constituição Dirigente..., cit., p. 260.
} 
imposições "concretas"150.

Interessa relevar que ele procura fincar as bases de um conceito material de imposições constitucionais. Argumenta que a visão processualística do problema, até então predominante, torna aquela construção teórica como uma linha auxiliar da ação constitucional de defesa contra as omissões legislativas. A seu ver, isso provocava uma interpretação restritiva dessas imposições, que seriam limitadas aos casos em que a Constituição fixasse um prazo de execução ou, no limite, uma ordem inequívoca dirigida ao legislador no sentido de emanar as leis necessárias à sua execução ${ }^{151}$.

As consequências de seu pensamento são muito claras: a vinculação jurídica (na verdade, "jurídico-constitucional" "152) do legislador à Constituição não implica que seja o Poder Judiciário (ou os Tribunais Constitucionais) o responsável pela garantia do cumprimento das imposições. Sim, pois se essas são dirigidas ao legislador, o "momento essencial [do cumprimento das imposições legiferantes] é a realização políticoconstitucionalmente imposta. (...) O problema da realização das imposições constitucionais é, simultaneamente, um problema político e normativo. Melhor dizendo: é um problema constitucional" ${ }^{, 153}$. Em suma: privilegia o cumprimento político de uma vinculação jurídica $^{154}$. Isso acontece mesmo em relação aos direitos fundamentais, pois a "perda de

${ }^{150}$ Cf.vCANOtilho, J. J. Gomes. Constituição Ddirigente..., cit., 315. Esse posicionamento, em termos de direitos sociais, é comum na doutrina de direitos fundamentais. José Carlos Andrade Vieira, quando trata desses direitos (que, na sua visão, não possuem o caráter de mera programaticidade), é taxativo ao sustentar que as normas que os preveem são diretivas ao legislador, são normas que impõem o dever de legislar. "O legislador não pode decidir se atua ou não: é-lhe proibido o "non facere"” (ANDRADE, José Carlos Vieira de. Os Direitos Fundamentais na Constituição Portuguesa de 1976, cit., p. 359). Confira-se ainda: SARLET, Ingo Wolfgang. A eficácia dos direitos fundamentais. $8^{\mathrm{a}}$ ed. Livraria do Advogado : Porto Alegre, $2007, \mathrm{p}$. 392; no mesmo sentido, mas de uma forma um pouco mais sofisticada: SILVA, Virgílio Afonso da Silva. Direitos fundamentais. Conteúdo essencial, restrições e eficácia. $2^{a}$ ed. São Paulo : Malheiros, 2010, pp. 7778. Nesse aspecto, a falta de atuação do legislador levaria à omissão inconstitucional. Essa posição não está livre de críticas, mormente quando se adota a postura luso-brasileira de sancionar o comportamento do legislador, pelo controle abstrato. Confira-se item 2.2.3, infra.

${ }^{151}$ Cf. CANOTILHO, J. J. Gomes. Constituição Dirigente..., cit., 302.

${ }_{152}$ Cf. CANOTILHO, J. J. Gomes. Constituição Dirigente..., cit., 306.

153 Cf. CANOTILHO, J. J. Gomes. Constituição Dirigente..., cit., p. 303. Ele complementa, na mesma página, que "a conciliação e a confrontação do jurídico-constitucionalmente imposto pela lei fundamental com o que é politicamente executado pelo legislador exige a consideração de várias dimensões - metódicas, teorético-constitucionais, dogmático-constitucionais e políticas - e não apenas a consideração unilateral do controlo das omissões legislativas".

${ }^{154}$ Essa conclusão é coerente com a construção teórica do autor lusitano, haja vista que o seu modelo de Teoria da Constituição prima pela condução política do Estado na consecução dos fins por ela traçados. A passagem a seguir demonstra claramente isso: "uma teoria de constituição constitucionalmente adequada deve, por conseguinte, tornar transparentes dois problemas fundamentais (1) que as tarefas de conformação sócio-econômica pressupõem, em geral, um "consenso" sobre a "planificação de fins", obtido num "espaço pré-constitucional" e, posteriormente vasado jurídico-constitucionalmente em tarefas e imposições constitucionais; (2) que as concretizações de fins e tarefas têm de ser efectuadas principalmente a nível político e legislativo. Eis por que a montante da constituição (momento constituinte) é crucial o problema do compromisso, e a jusante (concretização constitucional) assume papel relevante a actualização das normas 
justiciabilidade e a colocação dos direitos de prestações dentro da 'reserva do possível' e da 'reserva da lei' devem ser compensadas por uma intensificação de participação democrática na política dos direitos fundamentais" ${ }^{155}$. Porventura essa posição não converteria, ao fim e ao cabo, numa vinculação política?

Quando tratou do mandado de injunção, mais especificamente em relação aos direitos que demandam uma prestação positiva do Estado, ele utilizou o exemplo do direito de participação nos lucros por parte dos trabalhadores. Abstraindo-se a existência da lei (lei $\mathrm{n}^{\mathrm{o}} 10.101 / 2000$ ), se manifestou que um writ com esse fundamento mostrar-se-ia com todas as suas limitações: modo de cálculo, distribuição e participação dos lucros demandam necessariamente uma lei que defina o conteúdo do direito. Se, então, o judiciário se autocontém, então a solução a ser encontrada estaria em outra sede: a da luta cívica e política e não no campo estritamente jurídico-constitucional ${ }^{156}$.

A percepção da vinculação como algo político também se torna muito clara na passagem de sua obra em que ele conceitua a omissão inconstitucional. Tal como fê-lo nas imposições constitucionais, ele procura dar um tratamento material ao tema, rejeitando o conceito como um simples aporte (ou justificativa) ao posterior controle judicial daquele tipo de inconstitucionalidade. Com isso ele pretende evitar o enfraquecimento da força normativa da Constituição, pela "banalização das inconstitucionalidades", ao mesmo tempo em que procura "precisar os casos em que, no plano político-jurídico-constitucional, se pode e deve acusar o legislador de omissões inconstitucionais (haja ou não meios judiciais de controlo) ${ }^{, 157}$. Aqui cabe a dúvida: qual a utilidade de se insistir numa vinculação estrita e exclusivamente jurídica se não houver meios igualmente jurídicos (ou melhor, jurisdicionais) para a realização das imposições constitucionais?

Deveras, ele reforça a adoção de soluções marcadamente políticas, como a "luta pela participação e pela reclamação de instrumentos de democracia direta"

pelas instâncias políticas e legislativas. Compromisso e concretização pressupõem uma lei constitucional concebida como norma e medida da política, pelo que se devem reduzir as "erupções concretas", os momentos "acessórios" e "metas longínquas, perturbadoras da própria "actualização concretizadora" (CANOTILHO, J. J. Gomes. Constituição Dirigente..., cit., p. 157). A exceção ficaria por conta das omissões parciais ("desigualdade na distribuição de subvenções", "arbítrio na distribuição de bens contingenciados", "restrição injustas ao desenvolvimento de direitos", em que, por controle concreto, a jurisdição constitucional poderia colmatar a omissão, produzindo a decisão efeitos inter partes (op. cit., pp. 346 e 349).

${ }^{155}$ CANOTILHO, J. J. Gomes. Constituição Dirigente..., cit., p. 377.

${ }^{156}$ CANOTILHO, J. J. Gomes. Tomemos a sério o silêncio dos poderes públicos - o direito à emanação de normas jurídicas e a proteção judicial contra as omissões normativas. In TEIXEIRA, Sálvio de Figueiredo (org.). As garantias do cidadão na justiça. São Paulo : Saraiva, 1993, p. 366.

${ }^{157}$ CANOTILHO, J. J. Gomes. Constituição Dirigente..., cit., p. 333. Não há grifos no original. 
(estabelecimento de "ações populares" ou direito de iniciativa legislativa popular)" $" 158$. Essas soluções são, portanto, atribuições a cargo "do legislador, das forças políticas, dos cidadãos. É uma tarefa de participação e de responsabilidade político-democrática" "159 . "De tudo isso se deduz que o Direito Constitucional, sendo o Direito das normas fundamentais, da soberania em seu exercício, de princípios básicos como a liberdade e a igualdade, o Estado de Direito, o Estado democrático e o Estado Social, é de natureza primacialmente política tanto quanto o Direito das Finanças é de natureza financeira e o Direito Fiscal é de natureza tributária” ${ }^{160}$.

De consequência, é correto afirmar que as normas constitucionais vinculam positivamente o legislador (mesmo algumas normas criadoras de direitos sociais), possuem uma "força jurídica" capaz de traduzir-se em "normas impositivas de legislação", o que resulta a exclusão da possibilidade de o legislador recusar-se a legislar ${ }^{161}$. Mas isso não quer dizer que também não haja uma vinculação política. A propósito, e isso será tema de um tópico específico do próximo capítulo, há normas que, pela sua peculiaridade, impõem uma vinculação política tão ou mais intensa que a vinculação jurídica, o que torna a exigibilidade judicial de seu cumprimento uma atitude extremamente questionável. E essa vinculação política permite que o legislador, num ambiente dominado pela Constituição aberta, possa decidir, com base em critérios políticos, quando legislar.

O problema do conceito das omissões inconstitucionais será analisado a seguir. Por ora, o que foi dito até aqui tem a serventia de demonstrar o seguinte: se, da vinculação jurídica do legislador à Constituição lhe acarreta uma obrigação, mesmo em relação àquelas normas que não apresentam determinabilidade de conteúdo (como são as normas não preceptivas veiculadoras de direitos sociais), isso não implica necessariamente conferir justificação para toda e qualquer intervenção do Poder Judiciário, na hipótese de "inadimplemento" daquele dever. Isto é, justiciabilidade não é elemento componente caracterizador do silêncio legislativo como comportamento lesivo à Lei Fundamental ${ }^{162}$. ${ }^{158}$ Cf. CANOTILHO, J. J. Gomes. Constituição Dirigente..., cit., p. 348.
${ }^{159}$ Cf. CANOTILHO, J. J. Gomes. Constituição Dirigente..., , cit., p. 349.
${ }^{160}$ Cf. BONAVIDES, Paulo. Curso de Direito Constitucional. cit., pp. $463-464$.
${ }^{161}$ Cf. ANDRADE, José Carlos Vieira de. Os direitos fundamentais na Constituição portuguesa de 1976,
cit., p. 359 .
Em abono a essa afirmação, é oportuno trazer à baila excerto do voto do Ministro Sepúlveda Pertence,
quando do julgamento da Questão de Ordem do MI no $107 / \mathrm{DF}:$ “[c]reio que é um falso problema colocar o
problema da efetividade da Constituição como uma consequência da opção sobre a natureza jurídica do
mandado de injunção. Na verdade, supor que, por decisão judicial, se pudesse dar, de fato, efetividade
concreta a todos os avanços de uma Constituição de conteúdo prospectivo e transformador, como é a
Constituição, é, na verdade, um ilusionismo político, no mínimo; é exigir do Poder Judiciário o que ele não 
Para encerrar o tópico, faz-se necessário tecer uma última observação. A escolha quase que exclusiva da lição de J. J. Gomes Canotilho para explicar a natureza da vinculação do legislador à Constituição tem um propósito (que é desmistificador, diga-se). É que, no Brasil, o seu pensamento foi utilizado como justificativa para fomentar a atuação cada vez mais ativista da jurisdição constitucional, mormente em se tratando de combater o silêncio do legislador. Todavia, pelo que se viu, na verdade o que propunha o jurista lusitano era justamente o contrário, isto é, a saída político-democrática para a efetivação das normas constitucionais.

\subsubsection{As origens do reconhecimento da inconstitucionalidade por omissão}

Ao contrário do que sucedeu com o judicial review e, de certa forma, com o modelo europeu de controle de constitucionalidade por ação ${ }^{163}$, as omissões inconstitucionais não foram precedidas de um amparo teórico consistente ${ }^{164}$.

A ideia de que se pudesse sancionar o legislador pelo seu silêncio se deparava com atitudes reticentes na doutrina da primeira metade do século XX. Nesse sentido, é emblemática a posição reticente de Hans Kelsen sobre a possibilidade de controle das omissões constitucionais, mesmo que, em tese, admitisse a vulneração dessa natureza à Constituição. O que chama a atenção em seu pensamento é que semelhante dúvida não se justificaria exatamente por força do resquício da soberania do Parlamento ou porque isso implicaria ferir a liberdade de conformação do legislador. O que o leva a concluir pela dificuldade desse tipo controle é que - no contexto da Constituição de Weimar, que possuía vários dispositivos que se referiam "ao conteúdo de leis futuras" - as normas

pode dar sob esta ou aquela forma processual, porque são conquistas, são avanços que dependem necessariamente de jogo político, em particular, da tensão entre pressões contraditórias da sociedade civil sobre os órgãos de definição das prioridades da ação estatal; dependem, enfim, da ambiência de lutas e de pressões contrapostas, que é a ambiência de uma democracia”.

${ }^{163}$ Cabe aqui uma ressalva. O que foi dito não implica aceitação unânime e pacífica da possibilidade de fulminar uma lei por estar em desacordo com a Constituição. Na Alemanha em particular, o controle de constitucionalidade de uma lei foi precedida de intenso debate entre os que defendiam esse proceder e os que o julgavam uma afronta à presunção de constitucionalidade iuris et de iure da lei. Cf. VILLALÓN, Pedro Cruz. La formación del sistema europeo de control de constitucionalidad (1918-1939). Madri : Centro de Estudios Constitucionales, 1987, pp. 92-93.

${ }^{164}$ Em sentido contrário: MORAIS, Carlos Blanco de Morais. Justiça Constitucional. Tomo II, cit., p. 464. O autor não deixa claro, mas talvez se refira somente ao contexto português. 
constitucionais que prescrevem esses conteúdos simplesmente não produzem efeitos jurídicos ${ }^{165}$.

À exceção de Wessel ${ }^{166}$, somente a partir das primeiras sentenças em torno das omissões inconstitucionais é que o tema chamou a atenção da doutrina ${ }^{167}$. E isso não é difícil de ser justificado. Já se falou na constitucionalização de direitos fundamentais que estão na base do Estado Social e da vinculação dos poderes públicos àqueles direitos. A isso acresça-se ainda a aceitação da ideia sobre quem deveria ser o guardião da Constituição $^{168}$. Parecia, então, ser uma questão de tempo até que os tribunais constitucionais pudessem expandir ainda mais sua atuação rumo à afirmação de que o legislador também infringe a Constituição pela sua inércia qualificada ${ }^{169}$.

\subsubsection{A atuação do Tribunal Constitucional Federal alemão}

Ainda que alguém tenha observado que "o Estado de direito que consagrou a

${ }^{165}$ Cf. KELSEN, Hans. Teoria geral do direito e do Estado. $4^{\mathrm{a}}$ ed. São Paulo : Martins Fontes, 2005, pp. 373-374.

${ }^{166} \mathrm{Na}$ doutrina estrangeira sobre as omissões inconstitucionais, é fácil encontrar referências a Wessel, autor que teria, pela primeira vez, classificado as omissões inconstitucionais em absolutas e relativas, em trabalho datado de 1952, portanto, antes ainda das decisões pioneiras do Tribunal Constitucional Federal alemão sobre o assunto. O trabalho é denominado Die Rechtsprechung des Bundesverfassungsgerichts zur Verfassungsbeschwerde, publicado no periódico Deutsches Verwaltungsblatt. Por omissões absolutas, se entendia a ausência total de lei para atender um comando estatuído pela norma constitucional. Relativas, quando, presente a lei demandada, esta cumpria de modo insatisfatório aquela ordem. Pela leitura daquelas obras, o autor rechaçava as primeiras, reconhecendo apenas as relativas. Dizia ele que "eine Grundrechtsverletzung durch ein absolutes Unterlassen des Gesetzgebers", apud SEGADO, Francisco Fernandez. El control de constitucionalidad de las omisiones legislativas. Algunas cuestiones dogmáticas. Estudios Constitucionales, Año 7, $\quad \mathrm{N}^{\mathrm{O}} \quad 2, \quad 2009, \quad$ p. $26 . \quad$ Disponível em http://www.cecoch.cl/docs/pdf/revista_ano7-2-2009/estudios_el_control.pdf. Acesso em 20/04/2013, às 21:00h. Para o autor espanhol, a posição de Wessel se reflete no julgamento do BVerfGE de 19 de dezembro de 1951, o que faz sentido, considerando que, à ocasião, o Tribunal negou que houvesse, em prol de uma pessoa lesada em seu direito fundamental, direito subjetivo à legislação. Para tanto, conferir, também: MORTATI, Costantino. Appunti per uno studio sui rimedi giurisdizionali contro comportamenti omissivi del legislatore. Problemi di Diritto Pubblico nell'attuale esperienza costituzionale repubblicana. Racolta di scritti III. Milão: Dott. A. Giuffrè editore, 1972, p. 928; MENÉNDEZ, Ignacio Villaverde. La inconstitucionalidad por omisión, cit., p. 40; RODRIGUEZ, Jose Julio Fernandez. La inconstitucionalidad por omisión..., cit, p. 114.

167 Sobre as sentenças aditivas, as quais foram pensadas pela Corte italiana para confrontar as omissões legislativas, disse Vezio Crisafulli: “[i]mporta, invece, ricordare, e sottolineare decisamente, que esse sono nate da un'esigenza pratica, e non da astratte elucubrazioni teoriche. (...) La teorizzazione è venuta dopo (Cf. CRISAFULLI, Vezio. La corte costituzionale ha vent'anni. In: OCCHIOCUPO, Nicola. La corte costituzionale tra norma giuridica e realtà sociale. Bilancio di vent'anni di attività. Padova : CEDAM, 1984, p. 80).

${ }^{168}$ Recorde-se ainda que brevemente a célebre discussão entre Hans Kelsen e Carl Schmitt, a que se fez menção no primeiro capítulo.

169 Cf. LEAL, Roger Stiefelmann. O efeito vinculante na jurisdição constitucional. São Paulo : Saraiva, 2006, pp. 73-92. 
Constituição alemã não é um Estado emanado da jurisprudência" ${ }^{170}$, diga-se desde logo que a aceitação e os primeiros passos do controle da inconstitucionalidade por omissão deveu-se ao Tribunal Constitucional Federal alemão (Bundesverfassungsgericht - BverfG). Foi essa corte que pioneiramente posicionou-se no sentido de que o legislador possui obrigações junto à Constituição, cujo descumprimento pode revelar uma inconstitucionalidade.

Inicialmente, as discussões centraram-se sobre do cabimento ou não do recurso (ou queixa) constitucional (Verfassungsbeschwerde) para os casos de omissão do legislador. Havia o reconhecimento de que o comportamento omissivo poderia até lesar um direito fundamental do indivíduo. Nada obstante, era corrente a posição segundo a qual isso não poderia justificar o emprego do recurso constitucional ${ }^{171}$.

O próprio Tribunal num primeiro caso hesitou, tanto em relação ao reconhecimento da própria omissão legislativa inconstitucional, quanto ao cabimento daquele recurso. De fato, em decisão emanada em 19 de dezembro de 1951, pouco depois do início de suas atividades (ocorrida em 7 de setembro de 1951), negou o cabimento do recurso constitucional em casos de omissão do legislador. Tal recurso fora interposto por um cidadão que se achava incapacitado para o trabalho e requeria uma pensão para si e para seus três filhos menores. Não havia previsão legal para o benefício, tanto é que requereu ao Tribunal que determinasse ao Governo federal a apresentação de um projeto de lei para regulamentá-lo. O pedido fundava-se na vulneração a direitos fundamentais garantidos pela própria Constituição, em especial os artigos $1^{\circ}$ (dignidade humana), $2^{\circ}$ (direito ao livre desenvolvimento da personalidade) e $3^{\circ}$ (igualdade). A Corte reconheceu que a sujeição à Constituição exsurge para os órgãos constitucionais e administrativos.

\footnotetext{
${ }^{170}$ Cf. SHOLZ, Rupert. Alemania: cincuenta años de Corte Constitucional Federal. Anuario de Derecho Constitucional Latinoamericano. Konrad-Adenauer-Stiftung, 2002, p. 73. Traduzido de: "El Estado de derecho que consagró la Constitución alemana no es un Estado emanado de la jurisprudencia”. A propósito, sobre a importância da Corte Constitucional alemã para a irradiação da Constituição na realidade social da Alemanha, o mesmo autor observou ainda que "un sistema constitucional abierto en su normativa sociopolítica debe permanecer abierto a la implementación de un Estado de bienestar, pero debe presuponer también que éste adopte su forma concreta y actual a partir de las leyes simples. Nada está más comprometido con la situación sociopolítica concreta y las demandas sociales específicas que el mandato de hacer realidad el Estado Social. Una Constitución no podrá nunca desarrollar ella misma y en forma directa una "realidad social" ni diseñarla en forma definitiva. Haber comprendido esta realidad es probablemente uno de los mayores méritos de la Ley Fundamental alemana, y la jurisprudencia de la Corte Constitucional Federal en general ha hecho justicia a ese espíritu de La Carta Magna” (op. cit., p. 65).

${ }^{171}$ Veja-se em FRIESENHAHN, Ernest. La giurisdizione costituzionale nella Repubblica Federale tedesca. Quaderni della giurisprudenza costituzionale. Milão : Giuffrè editore, 1973, p. 87.
} 
Nada obstante, declarou que inexistia direito subjetivo à ação do legislador ${ }^{172}$.

Em 1953, a posição inicial da Corte começa a ser matizada. Determina o artigo 117,1 , da Constituição alemã que a legislação que porventura contrariasse o artigo $3^{\circ}, 2$ (que trata da igualdade de direitos entre homens e mulheres) poderia continuar em vigor até que o legislador as adaptasse. No entanto, isso não poderia passar de 31 de março de 1953. Passada essa data e omisso o legislador, a Corte declarou eficácia plena àquele dispositivo, o que acarretou a invalidez das normas que o contrariassem ${ }^{173}$.

Em 1957, com a famosa decisão BVerfGE 6, 257, de 20 de fevereiro, evidencia-se a continuidade do percurso evolutivo Tribunal no tratamento do silêncio legislativo inconstitucional. Nela, ao contrário de sentenças de anos anteriores, não vacilou em concluir que cabe, de forma direta, o recurso constitucional quando o legislador executa apenas de modo parcial seu dever de emanar uma lei, dever esse que lhe é constitucionalmente imposto. Quando não atende essa ordem, viola, por conseguinte, um direito fundamental (in casu, art. 3, Grundgesetz). Reconheceu, também, que o legislador não cumpriu contento o mandamento (ordem) constitucional prevista no artigo $131^{\circ}$ da Lei Fundamental. Obrigou-o, assim, a observar o princípio da isonomia e, de consequência, a regular a situação jurídica das pessoas que, sendo funcionários públicos em 8 de maio de 1945, haviam deixado de sê-lo por expulsão ${ }^{174}$. A Corte deu, então, os primeiros passos para o reconhecimento dogmático do que se denominou de "exclusão arbitrária de benefício" $" 175$.

É de grande significado a chancela da utilização do recurso constitucional no preenchimento de uma omissão inconstitucional, mesmo que baseada em um defeito da lei, pois resultou no contorno de um problema processual: a falta de instrumentos específicos

${ }^{172}$ Cf. TROCKER, Niccolò. Le omissioni del legislatore e la tutela giurisdizionale dei Diritti di Libertà. Studio comparativo sul diritto tedesco. Archivio Giuridico "Filippo Serafini”, volume CLXXVIII, Fascícolos 1-2. Modena : S.T.E.M. Mucchi, Janeiro/Abril, 1970, p. 105; Cf. SEGADO, Francisco Fernandéz. El control de las omisiones legislativas por el "Bundesverfassungsgericht". Teoria y Realidad Constituional. UNED, n. 22, 2008, p. 100. Disponível em http://www.juridicas.unam.mx/publica/librev/rev/trcons/cont/22/est/est2.pdf. Acesso em 20/10/2013, às 17:00h.

${ }^{173}$ Cf PICARDI, Nicola. Le sentenze "integrative" della Corte costituzionale". Rivista di Diritto Processuale, ano XXX, $\mathrm{n}^{\circ}$ 1. CEDAM, 1975, p. 54. Ver ainda em TROCKER, Nicolò, Le omissioni del legislatore e la tutela giurisdizionale dei Diritti di Libertà. Studio comparativo sul diritto tedesco, cit., p. 121.

${ }^{174}$ Cf. SCHWABE, Jürgen. Cinquenta anos de jurisprudência do Tribunal Constitucional Federal alemão. Konrad-Adenauer-Stiftung E.V, 2005, pp. 344-345; FRIESENHAHN, Ernst. La giurisdizione costituzionale nella Repubblica Federale tedesca. Quaderni della giurisprudenza costituzionale, cit. pp. 87-88.

175 Cf. SEGADO, Francisco Fernandez. El control de las omisiones legislativas por el Bundesverfassungsgericht. Teoria y realidad Constitucional, cit, p. 102; MENDES, Gilmar Ferreira. O controle da omissão inconstitucional. In SCHÄFER, Jairo Gilberto (org.). Temas polêmicos do constitucionalismo contemporâneo. Florianópolis : Conceito editorial, 2007, pp. 141-142. 
para lidar com as omissões legislativas ${ }^{176}$.

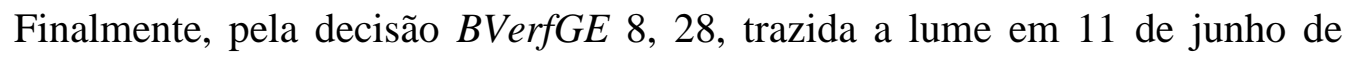
1958, aquela corte constitucional reconheceu de forma hialina a omissão inconstitucional. Trata-se de julgamento de recurso constitucional que tinha como objeto uma lei sobre salário do funcionalismo público (Besoldungsrecht). Esse diploma legal excluía do rol de beneficiários de um aumento de vinte por cento um grupo de aposentados. O Superior Tribunal Estadual de Nuremberg apresentou à Corte Constitucional dúvida acerca da constitucionalidade da lei, por ofensa ao princípio da igualdade (Art. 3 I, Grundgesetz). A Corte não declarou a inconstitucionalidade de nenhum dispositivo da lei. Nas razões de decidir, o Tribunal consignou expressamente que não poderia estender o aumento ao grupo excluído (do qual, o autor da ação originária, um funcionário dos Correios, fazia parte), porquanto não poderia fazer as vezes de legislador, em respeito à sua liberdade de conformação. Ou seja, não poderia, mediante interpretação extensiva, contemplar o grupo prejudicado se não pudesse determinar com segurança que o legislador teria tomado a mesma decisão, se tivesse observado o princípio da igualdade. No entanto, é importante consignar que o Tribunal reconheceu a ofensa ao direito do recorrente, em função da falta de observância do legislador do princípio da igualdade, isto é, por uma omissão inconstitucional $^{177}$ e 178 .

${ }^{176} \mathrm{Cf}$. SEGADO, Francisco Fernandéz. El control de las omisiones legislativas por el Bundesverfassungsgericht, cit., p. 96; MENDES, Gilmar Ferreira, O controle da omissão inconstitucional, cit., pp.141-142, nota ${ }^{\circ} 9$.

${ }^{177}$ Cf. MENDES, Gilmar Ferreira. O controle da omissão inconstitucional. Op. cit., pp. 141-142; SCHWABE, Cinquenta anos de jurisprudência do Tribunal Constitucional Federal alemão, cit., pp. 344-345.

${ }^{178}$ Além do reconhecimento da omissão inconstitucional, a Corte alemã ainda desenvolveu técnicas decisórias que ressaltam a omissão inconstitucional, ainda que não tente colmatá-la. Trata-se de uma "política jurisprudencial de renúncia à declaração de nulidade" (Cf. BÉGUIN, Jean-Claude. Le contrôle de la constitutionnalité des lois en République Féderale d'Allemagne. Paris : Economica, 1982, p. 209). Diante da evidenciação de uma inconstitucionalidade por omissão, mormente do tipo relativa por infringência ao princípio da igualdade, em que a lei exclui da fruição de algum benefício uma pessoa ou grupo de pessoas ou categoria profissional, o tribunal limita-se a declarar o ato inconstitucional. Nada obstante, para não criar um vazio jurídico, não o anula. Em respeito à liberdade de conformação do legislador, não restaura a igualdade violada (salvo em casos especiais, como visto acima em relação à igualdade entre homens e mulheres). É que ele entende que o legislador tem mais alternativas para a correção da situação exposta na lei, seja pela extensão do benefício mais favorável, extensão do benefício menos favorável ou simplesmente uma restruturação completa do regime de concessão do benefício. A última sentença citada acima é exemplo do que se acabou de falar. Atente-se, ainda, que o Tribunal apela ao legislador para que adeque a lei que, conquanto ainda seja compatível com a Constituição, caminha para uma situação de inconstitucionalidade. Considerando que o detalhamento dessas técnicas decisórias não faz parte do objeto do trabalho, somente por alto vão aqui registradas. Para uma melhor compreensão do tema, conferir: BÉGUIN, Jean-Claude. Le contrôle de la constitutionnalité..., cit., pp. 263-293; MENDES, Gilmar. Apelo ao legislador na Corte Constitucional alemã. Revista Trimestral de Direito Público. São Paulo : Malheiros Editores, no 10, 1995, pp. 33-51; SILVA, Jorge Pereira da. Dever de legislar e protecção jurisdicional contra omissões legislativas. Contributo para uma Teoria da Inconstitucionalidade por Omissão. Coimbra : Universidade Católica Editora, 2003, pp. 116-120; SEGADO, Francisco Fernandéz. El control de las omisiones legislativas por el 


\subsubsection{A atuação da Corte Constitucional italiana}

A partir da atuação do $B V \operatorname{erf} G E$, não tardou até que a Corte Constitucional italiana viesse a afrontar a falta de atuação do legislador.

O problema das omissões legislativas na Itália, a propósito, começa com inatividade do legislador republicano em eliminar ou emendar a legislação pré-fascista e fascista, o que acabou ficando a cargo da então recém-criada Corte. A magistratura ordinária havia considerado que tal legislação não estava derrogada, em virtude do caráter meramente programático da maior parte das normas constitucionais da nova Lei Maior ${ }^{179}$.

De forma geral, o conceito de omissão inconstitucional encontrado pela Corte italiana não difere daquele erigido pelo Tribunal Constitucional alemão: a mera inércia do legislador, a princípio irrelevante, se transforma em omissão não tolerada pela Constituição quando houver uma inatividade qualificada pela desobediência a um comando constitucional ou uma ação incompleta do legislador ${ }^{180}$.

O que é marcadamente diverso entre uma e outra é o modo como a Corte italiana tratou, principalmente nas primeiras duas décadas de seu funcionamento, os casos de omissão legislativa. Seguindo seara diversa da trilhada pelo Tribunal Constitucional alemão, aquela não se cercou, inicialmente, de muitos pudores para garantir-se o poder (ou dever) de preencher a norma incompleta ${ }^{181}$. Diante da "omissão histórica" do legislador italiano, a liberdade de conformação deste não era-lhe um obstáculo, mas, à evidência, um convite para um comportamento mais proativo.

Bundesverfassungsgericht, cit., pp. 110-121; BEILFUSS, Markus Gonzalez. Tribunal Constitucional y reparación de la discriminación normativa. Madri : Centro de Estudios Políticos e Constitucionales, 2000, pp. 194-205. Segundo o autor (p. 195), esse método acabou previsto na quarta lei de reforma da lei do Tribunal Constitucional Federal, aprovada em 12 de dezembro de 1970.

${ }^{179}$ Cf. IANUCCILLI, Loris. Parte I. Profili storici e teorici. In ITALIA. Corte Costituzionale. Problemi dell'omissione legislativa nella giurisprudenza costituzionale. Quaderno predisposto in occasione della Conferenza delle Corti Costituzionali europee. Vilnius 2-7 junho 2008, p. 8. Disponível em http://www.cortecostituzionale.it/documenti/convegni_seminari/STU199_Omissione_legislatore.pdf. Acesso em 15/10/2013, às 15:00h.

180 Cf. BELLOCCI, Mario; PASSAGLIA, Paolo. Parte II. La giurisprudenza costituzionale. Problemi dell'omissione legislativa nella giurisprudenza costituzionale. Quaderno predisposto in occasione della Conferenza delle Corti Costituzionali europee. Vilnius 2-7 junho 2008, p. 31. Disponível em http://www.cortecostituzionale.it/documenti/convegni_seminari/STU199_Omissione_legislatore.pdf. Acesso em 15/10/2013, às 16:00h.

${ }^{181}$ Para confirmar o que vai dito, ao interessado bastará consultar CRISAFULLI, Vezio. La corte costituzionale ha vent'anni. In OCCHIOCUPO, Nicola. La corte costituzionale tra norma giuridica e realtà sociale. Bilancio di vent'anni di attività, cit., especificamente a página 81 . 
De fato, a Corte revelaria seu perfil criativo declarando a inconstitucionalidade de leis em relação "não a que elas dizem, mas a que elas não dizem""182. Verificado esse tipo de defeito, o Tribunal se julga no dever de adicionar o fragmento normativo que entende estar faltante à norma objeto de controle ${ }^{183}$. Daí por que tais sentenças serem chamadas de aditivas ${ }^{184}$.

O fundamento teórico para essa atuação encontrou respaldo no pensamento de Vezio Crisafulli sobre o que ele chama de soluções a rime obbligate ${ }^{185}$, isto é, soluções que seriam impostas pela própria Constituição. Suas considerações partem da diferenciação entre dispositivo (texto formado por signos de linguagem) e norma (considerada como o resultado interpretativo do dispositivo), tão comum em tempos hodiernos ${ }^{186}$. A partir disso, ele sustenta que o Tribunal, ao adicionar à norma legal a parte que nela deveria constar haja vista o dispositivo portar consigo um elemento indevido de exclusão - nada mais faz que explicitar ou especificar algo que estava já compreendido, em estado latente, no próprio ordenamento. Assim, não se cuida de criar direito novo, mas integrar uma lacuna por analogia (e não por "fantasia da Corte" ${ }^{187}$ ). O ponto de partida para tanto poderia ser uma norma derivada de um princípio geral ou até mesmo da mesma norma constitucional violada pela omissão ${ }^{188}$.

\footnotetext{
${ }^{182}$ Cf. IANUCCILLI, Loris. Parte I. Profili storici e teorici, cit. p. 7.

${ }^{183}$ Destacou Costantino Mortati que as omissões da própria lei não se ligam necessariamente ao princípio da igualdade. Para qualquer caso em que se verifique o atendimento parcial da norma constitucional, estar-se-á diante de uma inconstitucionalidade. Essa é a razão pela qual, ele nega a classificação de Wessel em relação às omissões relativas (Cf. Appunti per uno studio sui rimedi giurisdizionali contro comportamenti omissivi del legislatore, cit., p. 928).

${ }^{184}$ Essas sentenças fazem parte de uma tipologia de manifestações da Corte mais extensa. Como ressalta Augusto Cerri, as sentenças "manipulativas" abrangem as interpretativas di rigetto, as interpretavas de acolhimento, as de acolhimento parcial, as aditivas, as substitutivas, as exortações e avisos ao legislador, as aditivas de princípio e as aditivas de processo (ou de mecanismo). O objeto do presente item é demonstrar o que a Corte entende por omissão inconstitucional. Logo, não se deterá nas explicações sobre o que seja cada uma dessas decisões. Para tanto, conferir, além dos autores citados nas notas anteriores: CERRI, Augusto. Corso di Giustizia Costituzionale. $5^{\text {a }}$ ed. Millão : Giuffrè Editore, 2008, pp. 256 e ss.; VEGA, Augusto Martín de La. La sentencia constitucional en Italia. Madri : Centro de Estudios Políticos y Constitucionales, 2003, pp. 215-326; BEILFUSS, Markus González. Tribunal Constitucional y reparación de la discriminación normativa, cit., pp. 118 e ss. e 205 e ss.

${ }^{185}$ Exatamente nestes termos decidiu a Corte, na ordinanza 380, de 6 de novembro de 2006, ao asserverar que a "Corte ha ripetutamente affermato (sentenze n. 308 e 258 del 1994, n. 298 del 1993, tra le altre) che le pronunce additive (come quella richiesta dall'odierno rimettente) sono consentite solamente quando la questione si presenti a rime obbligate, cioè quando la soluzione sia logicamente necessitata ed implicita nello stesso contesto normativo". Inteiro teor disponível em http://www.cortecostituzionale.it/actionPronuncia.do. Consultado em 16/10/2014, às 10:00h.

${ }^{186}$ Veja-se em GRAU, Eros Roberto. Ensaio e discurso sobre a interpretação/aplicação do direito. $5^{\mathrm{a}}$ ed. São Paulo : Malheiros, 2009, pp. 86-89.

${ }_{187}$ CRISAFULLI, Vezio. Lezioni di Diritto Costituzionale. Vol. II2. Pádua (Italia) : CEDAM, 1978, P. 366.

${ }^{188}$ CRISAFULLI, Vezio. La corte costituzionale ha vent'anni, cit, p. 84.
} 
Essa solução procura atingir não "a manifestação de vontade negativa" do legislador, mas o seu resultado: as normas negativas implícitas extraíveis dos artigos julgados inconstitucionais na parte em que a Corte entendeu haver uma exclusão indevida $^{189}$. Tratar-se-ia do que se chamou de uma "omissão-produto"190. A Corte Constitucional incorporou de tal forma essa vertente teórica, que nos casos em que não se evidenciem claramente as rime obbligate, a única solução seria julgar improcedente o pedido de declaração de inconstitucionalidade do ato normativo questionado ${ }^{191}$.

Assim, na sentença $\mathrm{n}^{\circ} 168$, de 12 de dezembro de $1963^{192}$, a Corte decidiu que o artigo 11, primeira parte, da lei $n^{\circ} 195$, de 24 de marzo de 1958, que criara o Conselho da Magistratura, era inconstitucional na parte que limitava a apreciação pelo órgão de matérias envolvendo magistrados à provocação do Ministro da Justiça. O Tribunal entendeu que essa disposição afrontava a Constituição (artigo 107) não porque implicava risco de uma indevida ingerência do Poder Executivo, mas sim porque a interpretação segundo a qual exclusivamente por provocação é que o Conselho poderia tratar daquelas matérias significaria perda de autonomia do próprio órgão (e assim, do próprio Poder Judiciário). O efeito aditivo/modificativo da sentença está nisto: o Conselho pode tratar das matérias constantes no artigo 10, I, independentemente de provocação do Ministro da Justiça.

Outro pronunciamento de bastante relevo diz respeito à sentença $\mathrm{n}^{\circ} 190$, de 10 de dezembro de $1970^{193}$. Nesse caso, a Corte julgou inconstitucional o artigo 304 bis, do Código de Processo Penal, na parte em que não previa a presença do defensor no interrogatório do réu, mas somente a do Ministério Público. De igual modo, na sentença $\mathrm{n}^{\circ}$ 9, 5 de fevereiro de $1964^{194}$, em que houve a declaração de inconstitucionalidade de dispositivo que limitava a representação em caso de crime praticado contra menor a somente ao genitor que exercício o pátrio poder, estendendo-a, por conseguinte, ao outro.

\footnotetext{
${ }^{189}$ Cf. IANUCCILLI, Loris. Parte I. Profili storici e teorici, cit., p. 22.

${ }^{190} \mathrm{Cf}$. PICARDI, Nicola. Le sentenze “integrative” della Corte costituzionale, cit., p. 44.

${ }^{191}$ Este, aliás, era uma exigência que a Corte fazia ao juiz ordinário, consubstanciando-se em verdadeiro caso de autocontenção ou, pelo menos, de um ponto de equilíbrio entre a atuação da jurisdição constitucional e a do legislador. Confira-se dentre outros, VEGA, Augusto Martín de La. La sentencia constitucional en Italia, cit., p. 298.

192 Audiência pública em 23 de outubro de 1963. Inteiro teor do julgamento disponível em http://www.cortecostituzionale.it/actionPronuncia.do. Acesso em 15/10/2014, às 16:00h

193 Audiência pública em 28 de dezembro de 1970. Inteiro teor do julgamento disponível em http://www.cortecostituzionale.it/actionPronuncia.do. Acesso em 15/10/2014, às 16:30h.

${ }_{194}$ Audiência pública em 04 de dezembro de 1963. Inteiro teor do julgamento em http://www.cortecostituzionale.it/actionPronuncia.do. Acesso em 16/10/2014, às 16:00h
} 
Na definição de obrigações do legislador, a Corte italiana combinou o dever de reposição da igualdade com direitos sociais, estreitamente conexos à ideia de EstadoProvidencia. Em temas como direito ao trabalho, prestações previdenciárias e à assistência pública, expandiu os efeitos de sentenças aditivas, estendendo benefícios financeiros e sociais a certos grupos que, em sua avaliação, foram indevidamente excluídos pela lei controlada. A consequência disso é que decisões desse naipe implicaram novas despesas para a Fazenda Pública. Não por outro motivo essas polêmicas sentenças são conhecidas como sentenze di prestazione. Esses posicionamentos são controversos pelo fato de o artigo 81.3, da Constituição italiana determinar que "ogni legge che importi nuovi o maggiori oneri provede ai mezzi per farvi fronte" ${ }^{\text {195 }}$.

Como ressalta Augusto Martín de la Vega, houve acesa discussão na doutrina italiana, entre aqueles que entendiam que o artigo era aplicável também ao Tribunal e não só ao Parlamento e os que sustentavam que tal preceito não pode implicar um limite à atuação da Corte. Estes argumentavam, em suma, que o atendimento a imperativos constitucionais, como os princípios, assume caráter obrigatório ${ }^{196}$.

A Corte italiana, porém, passou ao largo dessa discussão. Mas, ao mesmo tempo em que rejeitava o artigo 81 como um limite à sua atuação, tinha-o como um dos fatores a ser levado em conta quando do julgamento da razoabilidade da lei objeto de controle $^{197}$. Assinalam Mario Bellocci e Paolo Passaglia que o efeito dessa ponderação (bilanciamento) a cargo da Corte era evidente: nos julgamentos que tinham como pano de fundo o princípio da igualdade, quando o Tribunal não incluía nos fundamentos de sua decisão considerações sobre as finanças públicas, tendia a estender determinado beneficio a algum grupo excluído da lei (isto é, fazia uma equiparação "por cima”). Por outro lado, quando recorria à ponderação supracitada, procedia a uma equiparação "por baixo", ou seja, limitava o grupo destinatário do benefício àquele previsto na lei, deixando de fora o que estava em situação equivalente, mas não contemplado pela norma ${ }^{198}$.

\footnotetext{
${ }^{195}$ A redação deste artigo encontra-se conforme a reforma estatuída pela Lei Constitucional no 20 , de 20 de abril de 2012. Antes da reforma, o conteúdo do comma 3 estava previsto no comma 4 e estava gizado da seguinte forma: "ogni altra legge che importi nuove e maggiori spese deve indicare i mezzi per farvi fronte". ${ }_{196}$ Cf.VEGA, Augusto Martín de La. La sentencia constitucional en Italia, cit., pp. 317-318.

${ }^{197}$ Cf. VEGA, Augusto Martín de La. La sentencia constitucional en Italia, cit., p. 320.

${ }^{198}$ Cf. BELLOCCI, Mario; PASSAGLIA, Paolo. Parte II. La giurisprudenza costituzionale, cit., p. 50.
} 
Registre-se um último aspecto digno de nota. Passado o ímpeto normativo, a partir dos anos $1980^{199}$, mormente no âmbito de sentenze di prestazione, a Corte Constitucional começou a fazer uso de técnicas decisórias específicas. Uma delas é a sentenza di principio. Por ela, a Corte constata a omissão e ao mesmo tempo a pluralidade de soluções normativas e declara a inconstitucionalidade parcial do preceito impugnado (na parte em que não prevê determinada situação que deveria estar normativizada, como nas aditivas clássicas). Contudo, limita-se a indicar o princípio que o legislador deverá atender ao criar a normativa exigida pela Constituição, deixando-lhe o dever de emanar a disciplina necessária ${ }^{200}$. A função desse tipo de sentença é estabelecer com o legislador um diálogo, apontando um defeito na lei e exortando-o a saná-lo. O efeito de amenizar a tensão com o legislador (e, por que não, com o Executivo? ${ }^{201}$ é patente. Ao mesmo tempo, atribui ao juiz o encargo de extrair do ordenamento jurídico, quando for possível, a norma aplicável ao caso concreto, até o legislador apresente a solução específica ao caso ${ }^{202}$.

Incluem-se nessa categoria as chamadas sentenças-advertência (sentenze monito). A Corte faz uso dessa sentença para "advertir" o legislador sobre determinada situação de inconstitucionalidade causada por omissão. Essas sentenças apresentam-se em

\footnotetext{
${ }^{199}$ São representativas desse tipo de sentença as de $\mathrm{n}^{\circ} 560$, de 10 de dezembro de 1987 e a sentença ${ }^{\circ} 497$, de 21 de abril 1988. Pela primeira, a Corte julgou inconstitucional o artigo 21, 1, da lei 990/69 (relativa a seguro obrigatório de responsabilidade civil de veículos automotores e náuticos), na parte em que limitava a indenização ao montante de 15 milhões de liras por cada vítima de acidente, e no máximo 25 milhões por sinistro. A Corte não estabeleceu, no entanto, nenhuma forma de adequação desses valores. Pela segunda, julgou inconstitucional o artigo 13, do Decreto-Lei $\mathrm{n}^{\circ}$ 30/74, na parte em que previa uma indenização aos trabalhadores desempregados involuntariamente, por entender insuficiente para garantir os meios de vida necessários e que o legislador deveria ter previsto mecanismos de adequação da soma ali estipulada (oitocentas liras mensais). Cf. BELLOCCI, Mario; PASSAGLIA, Paolo. Parte II. La giurisprudenza costituzionale, cit., p. 57; ZAGREBELSKY, Gustavo; MARCENÒ, Valeria. Giustizia Costituzionale, cit., pp. 403-404. Inteiro teor dos julgamentos disponível em http://www.cortecostituzionale.it/actionPronuncia.do. Acesso em 17/10/2014, às 16:00h.

${ }^{200}$ Cf. MEZZETTI, L.; BELLETTI, M.; D’ORLANDO, E.; FERIOLI, E. Giustizia Costituzionale. Pádua : CEDAM, 2007, p. 436.

${ }^{201}$ Esse caráter de auto-contenção pode ser resumido na seguinte passagem: "tuttavia, non è dubbio che le difficoltà che su questo terreno [o das sentenze di prestazione] incontra la giurisdizione costituzionale siano la manifestazione del fatto che la giustizia costituzionale non è stata pensata e non è nata per operare nel campo dei diritti social, cioè, i diritti 'che costano'. La sua matrice è liberale, legata alla difesa contro gli arbitri dell'autorità e dunque attrezzata per impedirli. Essa non è, in origine, un'istituzione dello Statoprovvidenza o dello Stato del benessere. Ciò non vuol dire che debba essere emarginata dalla tutela dei diritti costituzionali ch'eso garantisce ai suoi cittadini: spiega le difficoltà e sprona a cercare soluzioni” (Cf. ZAGREBELSKY, Gustavo; MARCENÒ, Valeria. Giustizia Costituzionale, cit., pp. 407-408).

${ }^{202}$ Assim disse a Corte, na sentença $\mathrm{n}^{\circ}$ 295, de 17 de julho de 1991 (Publicação: 03/07/1991): "la dichiarazione di illegimità costituzionale di una omissione legislativa - com'è quella ravvisata nell'ipotesi di mancata previsione, da parte della norma di legge regolatrice di un diritto costituzionalmente garantito, di un meccanismo idoneo ad assicurare l'effetività di questo - mentre lascia al legislatore, riconoscendone l'innegabile competenza, di introdurre e di disciplinare anche retroattivamente tale mecanismo in via di normazione astratta, somministra essa stessa un principio cui il giudice comune è abilitato a fare riferimento per porre frattanto rimedio all'omissione in via di individuazione della regola del caso concreto". Cf. BELLOCCI, Mario; PASSAGLIA, Paolo. Parte II. La giurisprudenza costituzionale, cit., p. 59. Inteiro teor disponível em http://www.cortecostituzionale.it/actionPronuncia.do. Consultado em 17/10/2014, às 20:40h.
} 
graus diferentes, que podem variar desde "convites" ao legislador, para sanar uma situação que é ainda constitucional, mas caminha para a inconstitucionalidade, a "ameaças" de futura declaração de inconstitucionalidade. Quando se apresentam no modo mais brando, é impossível não compará-las ao "apelo ao legislador" do direito constitucional alemão.

\subsection{O descumprimento de um dever de legislar como principal parâmetro para aferição da ocorrência de uma omissão inconstitucional}

Os primeiros pronunciamentos das Cortes Constitucionais supracitadas brevemente comentados acima e que orbitaram a tutela e fruição de certos direitos fundamentais - acabaram por direcionar o tratamento teórico das omissões inconstitucionais.

De fato, a construção do conceito da inconstitucionalidade por omissão baseouse na definição de obrigação ser adimplida por um agente. A ideia geral é a de que Constituição impõe obrigações ao legislador.

O sentido da omissão como descumprimento de uma obrigação é tão forte que autores que iniciaram o estudo teórico desse fenômeno o extraem do direito penal (mais precisamente, do crime de omissão) e do direito civil ${ }^{203}$.

Entretanto, não é o silêncio legislativo em relação a uma norma constitucional qualquer que pode gerar a inconstitucionalidade, mas sobre a que tenha a qualidade de "imperativa”, isto é, aquela em função da qual "os órgãos legislativos não devem somente respeitar certas formas e condições estabelecidas pela Constituição, mas são obrigados a dispor em relação a certos objetos e a determinadas matérias" ${ }^{204}$. E essa qualidade é mais evidente quando se trata de proceder à tutela dos direitos considerados fundamentais ${ }^{205}$.

Há quem veja a necessidade de implementação de outro requisito. A omissão deve ser resultado de um ato doloso do legislador. Sem a intenção de não legislar não há

${ }^{203}$ É o caso de TROCKER, Nicolò. Le omissioni del legislatore e la tutela giurisdizionale dei Diritti di Libertà. Studio comparativo sul diritto tedesco, cit, p. 100. Posteriormente, outros autores assim o fizeram, como RODRIGUEZ, Jose Julio Fernandez. La inconstitucionalidad por omisión..., cit., p. 73. Entre nós: CLÈVE. Clèmerson Marlin. A fiscalização abstrata da constitucionalidade no direito brasileiro. $2^{\mathrm{a}}$ ed. São Paulo : Editora Revista dos Tribunais, 2000, p. 324; ROSA, André Vicente Pires. Las omisiones legislativas y su control constitucional. Rio de Janeiro : Renovar, 2006, pp. 134-135.

${ }^{204}$ Cf. TROCKER, Nicolò, Le omissioni del legislatore e la tutela giurisdizionale dei Diritti di Libertà. Studio comparativo sul diritto tedesco, cit, p. 103.

${ }^{205}$ Cf. MORTATI, Costantino. Appunti per uno studio sui rimedi giurisdizionali contro comportamenti omissivi del legislatore, cit., p. 992. 
inconstitucionalidade, mas mera lacuna, as quais seriam fruto de inércia legislativa involuntária $^{206}$. Disso resulta que o que é censurável, pelo controle de constitucionalidade, em suma, é a decisão política de não legislar ${ }^{207}$.

Evidentemente, não se trata de um racionício referendável. A “vontade” de não legislar consubstancia-se critério marcadamente abstrato de difícil verificação. Para a caracterização desse fenômeno é o aspecto objetivo que deve contar: falta de uma lei necessária resultante da vulneração de um dever de legislar (tome-se ou não o elemento temporal como relevante).

Consigne-se, por oportuno, que também não é qualquer dever vulnerado que está apto caracterizar uma inconstitucionalidade por omissão. Dessa classe, haverão de ser excluídos os deveres gerais e abstratos. A omissão legislativa relevante não é a decorrente de um não fazer genérico, ou "não é um conceito naturalístico". Tratar-se-ia de deixar de fazer algo "a que, de forma concreta e explícita, estava constitucionalmente obrigado"208. Por isso mesmo, as omissões legislativas lesivas à Constituição são, por definição, antijurídicas $^{209}$. Logo, a vulneração da Constituição

verifica-se sempre que, perante uma obrigação de facere, e mandando, direta ou indiretamente a norma, norma reguladora de certa relação ou situação praticar certo ato ou certa atividade nas condições que estabelece, o destinatário não o faça, não o faça nos termos exigidos, não

206 Cf. MORTATI, Costantino, Appunti per uno studio sui rimedi giurisdizionali contro comportamenti omissivi del legislatore, cit., p. 927 , nota de rodapé $n^{\circ} 4$. Para o autor italiano, a sentença que preenche a lacuna exaure a função de integração do ordenamento jurídico. Já a que declara a inconstitucionalidade por omissão pode ser, por sua vez, fonte de outras lacunas. É claro que, para esta última hipótese, o autor está pensando na declaração de inconstitucionalidade acompanhada da anulação da lei incompleta, isto é, para os casos de omissão relativa, classificação que ele mesmo rechaça. Na sua opinião, reconhecida a omissão inconstitucional, o juiz tem sempre poder normativo, ainda que subsidiário. Disso decorre que é de pouca relevância classificar as omissões em totais ou parciais, absolutas ou relativas. Cf. MORTATI, Costantino, Appunti per uno studio sui rimedi giurisdizionali contro comportamenti omissivi del legislatore, cit., p. 927, nota de rodapé $\mathrm{n}^{\circ} 4$.

${ }^{207}$ Nesse sentido: MENÉNDEZ, Ignácio Villaverde. La inconstitucionalidad por omisión, cit., p. 70. Este autor ressalta que o enfoque de Costantino Mortati frisa a natureza política do silêncio do legislador. (Cf. MORTATI, Costantino. Appunti per uno studio sui rimedi giurisdizionali contro comportamenti omissivi del legislatore, cit., p. 937).

${ }^{208}$ Cf. CANOTILHO, José Joaquim Gomes. Direito Constitucional e Teoria da Constituição. Almedina, 2003, pp. 1035 e 1036. Ver ainda: CANOTILHO, José Joaquim Gomes. Tomemos a sério o silêncio dos poderes públicos - o direito à emanação de normas jurídicas e a proteção judicial contra as omissões normativas. In TEIXEIRA, Sálvio de Figueiredo (org.). Op cit., p. 355; e, é claro: CANOTILHO, José Joaquim Gomes. Constituição Dirigente e Vinculação do legislador. Coimbra : Coimbra editorial, 1994, pp. 331-332.

${ }^{209}$ SILVA, Jorge Pereira da. Dever de legislar e protecção jurisdicional contra omissões legislativas, cit., p. 12. 
o faça em tempo útil, e a esse comportamento se liguem consequências mais ou menos adequadas ${ }^{210}$.

Assim, a omissão inconstitucional diferencia-se da mera inércia legislativa "pela presença de um dever jurídico inerente à função legislativa", em que a produção normativa se encontra condicionada não só do ponto de vista formal ou de oportunidade política, mas também em relação ao seu conteúdo material ${ }^{211}$.

Nesse grupo figurariam também as ordens de legislar, representadas por normas que demandam atuação legislativa concreta e única (ainda que por várias leis). Delas o legislador se desincumbe ao produzir a lei (ou leis) exigida (s), sem a necessidade de constante revisão. O exemplo fornecido habitualmente é o da necessidade de lei para a criação de órgãos, como o Tribunal Constitucional ${ }^{212}$.

A lesão à Constituição ocorre, enfim, quando o legislador não observa a concretização de certas normas constitucionais e, com isso dá causa a uma ineficácia provocadora de uma "fraude constitucional", por tornar inaplicável a Constituição ${ }^{213}$.

Há quem sustente que, além de normas constitucionais precetivas não exequíveis, as normas programáticas também podem dar azo a uma omissão inconstitucional $^{214}$. O problema é saber em que medida isso seria possível, uma vez que normalmente são normas que demandam não só a atuação legislativa, mas também dependem da incidência de fatores de índole material (econômico-social) e de providências que envolvem, além das instâncias políticas, a administrativa. A derradeira parte deste trabalho cuidará desse aspecto.

210 Cf. MIRANDA, Jorge. Manual de Direito Constitucional. Inconstitucionalidade e garantia da Constituição. Tomo VI. cit, p. 360. Sentido semelhante é o de Carlos Blanco de Morais, que, em sentido lato, define a omissão inconstitucional como "a abstenção de um órgão do Estado Colectividade em cumprir com deveres ou obrigações activas que lhe sejam imperativamente determinados pela Constituição" (Cf.. Justiça Constitucional, tomo II, cit., p. 456).

${ }^{211}$ PUENTE, Marcos Gómez. La inactividad del legislador: una realidad susceptible de control. Madrid : McGraw-Hill, 1997, p. 19.

${ }^{212}$ Cf. CANOtilhO, J. J. Gomes. Direito Constitucional e Teoria da Constituição, cit, pp. 1035-1036; CANOTILHO, J. J. Gomes. Constituição dirigente..., cit., pp. 315-316 e 331-333.

${ }_{213}$ Cf. RODRIGUEZ, Jose Julio Fernandez. La inconstitucionalidad por omisión..., cit., p. 203.

${ }^{214}$ Por todos: MIRANDA, Jorge. Manual de Direito Constitucional. Tomo VI, cit., pp. 371-372; MIRANDA, Jorge. A fiscalização da inconstitucionalidade por omissão. Revista Direito e Liberdade. Esmarn, v. 14, $\mathrm{n}^{\circ} 1$, jan/jun 2012, pp. 14-21. Disponível em www.esmarn.tjrn.jus.br, consultado em 10/05/2013, às 15:00h; PUENTE, Marcos Gómez. La inactividad del legislador: una realidad susceptible de control, cit., p. 77-79. Em sentido contrário: CANOTILHO, J. J. Gomes. Direito Constitucional e Teoria da Constituição, cit., p. 1035 . 


\subsection{Os diferentes modos de compreender e controlar a inconstitucionalidade por omissão}

Quando foram analisadas as atuações pioneiras do Tribunal Constitucional Federal alemão e da Corte Constitucional italiana, percebeu-se que, enquanto a primeira era mais cautelosa no oferecimento de soluções para as omissões inconstitucionais, a segunda desenvolveu toda uma tipologia de decisões notadamente ousadas. A partir da raíz comum do conceito da inconstitucionalidade por omissão, duas correntes teóricas se formaram em torno desse fenômeno.

\subsubsection{O controle da omissão inconstitucional como censura ao comportamento desidioso do legislador}

A primeira, ao compreender as omissões legislativas como mora do legislador, defende que o controle de constitucionalidade é composto pelo esquema: (a) explicitação da frustração de um dever de legislar, (b) a consequente censura da atitude omissa do legislador e, finalmente, (c) o reconhecimento de um direito individual a que o legislador legisle, ou, em último caso, um direito à própria norma faltante ${ }^{215}$. Por conseguinte, a omissão inconstitucional se reduz a um problema de "responsabilidade do legislador por seus silêncios" e "que a única sanção possível para a inércia do órgão é compeli-lo a legislar, e inclusive a fazê-lo com um conteúdo determinado (...)"216. Não por outra razão essa corrente foi denominada de "obrigacionista".

A omissão inconstitucional, portanto, é resultado da lesão a uma reserva de lei, visto ser esse o critério para o estabelecimento constitucional do dever de legislar. Sem dúvida alguma, esse modo de enxergar a omissão inconstitucional encontra melhor justificação teórica no dirigismo constitucional. Também não é por outro fundamento que se critica essa concepção por propiciar o rebaixamento da Constituição a uma espécie de contrato.

${ }^{215}$ Cf. MENENDEZ, Ignacio Villaverde. La inconstitucionalidad por omisión, cit., p. 97.

${ }^{216}$ Cf. MENENDEZ, Ignacio Villaverde. La inconstitucionalidad por omisión, cit., p. 32. Traduzido de: “(...) como un problema de responsabilidad del legislador por sus silencios" e "que la única sanción posible par a la quiescencia del órgano es su compulsión a legislar, e incluso a hacerlo con un contenido determinado". 


\subsubsection{O controle da omissão inconstitucional a partir de um resultado normativo decorrente do comportamento desidioso do legislador}

Por outro lado, há quem enfatize a omissão inconstitucional apenas como um resultado normativo produzido pela inobservância de um dever de legislar. Nesse caso, verifica-se um claro deslocamento do núcleo conceitual. Este transita do comportamento omissivo do legislador para os efeitos que dele se originam, tendo como parâmetro a própria Constituição. A utilização de sentenças manipulativas, principalmente as de conteúdo aditivo, conduziu à compreensão de que a inércia legislativa é uma mera escolha política do legislador. Eventual decisão de não legislar não é relevante do ponto de vista jurídico, mas "somente para fins de uma explicação política ou sociológica" do fenômeno da omissão inconstitucional ${ }^{217}$.

Por essa corrente, o que importa mesmo é eliminar um obstáculo causado pela omissão legislativa: a norma implícita negativa (ou impeditiva) ${ }^{218}$. Essa norma implicita seria o resultado interpretativo a contrario sensu do dispositivo constitucional, em relação a uma situação sobre a qual este silencia e que deveria ter sido por ele abarcada. Assim, quando a jurisdição constitucional percebe essa situação e "completa" a norma, não estaria a "inventar" direito novo, mas tão-somente aplicando outra norma já existente no ordenamento jurídico. Seria, assim, um exercício de restituição de uma eficácia mais ampla da norma, anteriormente obstacularizada pelo que a disposição controlada não dizia ${ }^{219}$. Como se pode notar, tal corrente, dita "normativista" 220 , deriva diretamente do modo de encarar as omissões legislativas desenvolvido pela Corte italiana.

${ }^{217}$ Cf. PICARDI, Nicola. Le sentenze "integrative" della Corte Costituzionale. Rivista di Diritto Processuale. Pádua, 1975, p. 45. Recorde-se, porém, a posição de Costantino Mortati, que inclui o "dolo" como elemento diferenciador entre omissão inconstitucional e lacuna técnica.

218 Augusto Martin de la Vega faz um interessante inventário dos autores italianos que defendem essa posição. Conferir: VEGA, Augusto Martin de la. La sentencia constitucional en Italia, cit., pp. 239-243.

${ }^{219}$ Para não tornar o texto enfadonho e repetitivo, conferir a posição de Vezio Crisafulli, no item 2.1.2.2. Ainda dentro dessa concepção, Costatino Mortati tinha uma posição um pouco diferente. Ele considerava que o Tribunal, excentuando-se os casos mais simples de exclusão de algo que o dispositivo controlado não diz, cria sim norma. Por isso, o pronunciamento jurisdicional não é meramente negativo, pois, pelo menos, a jurisdição constitucional deve deixar assentes os critérios que deveriam informar a regulação daquela situação não contemplada pela lei omissa. No entanto, essa norma nova não decorre de voluntarismo do juiz. A solução é extraível do bojo do próprio ordenamento. Cf. MORTATI, Costantino. Appunti per uno studio sui rimedi giurisdizionali contro comportamenti omissivi del legislatore, op. cit., pp. 940 e 952; VEGA, Augusto Martin de la. La sentencia constitucional en Italia. cit, pp. 238- 239. Este autor espanhol afirma que tal posicionamento não implica concluir que o mestre italiano entende que necessariamente deverá ser o Tribunal Constitucional o órgão a criar efetivamente a norma faltante.

${ }^{220}$ Há autores que criticam tal dicotomia, considerando que a omissão inconstitucional é na realidade um fenômeno "bifronte": SEGADO, Francisco Fernández. El control de constitucionalidad de las omisiones legislativas. Algunas cuestiones dogmáticas. Op. cit., pp. 31-32; SILVA, Jorge Pereira da. Dever de legislar e protecção jurisdicional contra omissões legislativas..., cit., p. 13. 
Por conseguinte, por esse modo de entender o fenômeno da inconstitucionalidade por omissão, o controle se dá no âmbito concreto, porquanto depende da análise de fatos para que se conclua se a omissão legislativa causa ou não o aparecimento da referida norma implícita ${ }^{221}$.

Autores contemporâneos há que, partindo dessa concepção inicial, alargam ainda mais seu âmbito de aplicação. Consideram ainda que haverá infringência da Constituição quando o silêncio legislativo der causa à produção de um resultado normativo contrário à Constituição, tal qual descrito acima. Mas não importa, todavia, se a lei que regulamenta determinado dispositivo constitucional é incompleta ou se simplesmente inexiste tal ato normativo ${ }^{222}$.

Como então reconhecer uma situação contrária ao que dispõe ou pretende a Constituição? De um modo geral, em primeiro lugar, deve-se separar as normas constitucionais que dão plena liberdade ao legislador para atuar das que lhe imputam, imperativamente, uma ordem de desenvolvê-las, ou seja, dar-lhes concreção. Aquelas normas geralmente são as que atribuem mera competência (ao Parlamento ou a qualquer outro Poder com poder jurídico para criar normas que regulem dada matéria, como o Poder Executivo, por exemplo ${ }^{223}$ ) ou são as autoaplicáveis.

Sobre as primeiras, o silêncio de modo algum proporciona um efeito jurídico relevante, justamente porque a própria Constituição prevê (ou pelo menos admite) que o legislador age se quiser. Ou melhor: são casos em que a Constituição encara como uma permissão "a decisão sobre introduzir ou não poder público em determinada matéria, criando ou não a instituição, regulando ou não a relação sociopolítica que constitui seu

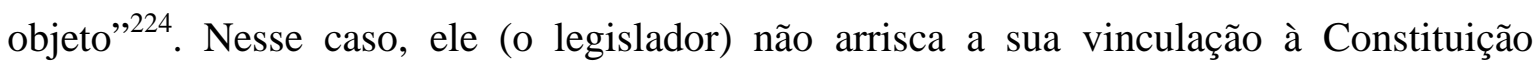
porque foi esta mesma quem deu a oportunidade de calar-se. "Em última análise, a norma constitucional permissiva tolera a existência no ordenamento jurídico de duas possíveis situações jurídicas [existência ou inexistência], inclusive antagônicas, e tão-só estabelece

\footnotetext{
${ }^{221}$ MENÈNDEZ, Ignacio Villaverde. La inconstitucionalidad por omisión, cit., p. 143.

${ }^{222}$ MENÈNDEZ, Ignacio Villaverde. La inconstitucionalidad por omisión, p. 33, 39, 49, 67, 73, 109-114. Entre nós: ROSA, André Vicente Pires. Las omisiones legislativas y su control constitucional, cit., p. 140.

${ }^{223}$ No caso da Constituição brasileira de 1988 , poder-se-ia pensar na hipótese prevista pelo artigo $25, \S 3^{\circ}$, que permite aos Estados, mediante lei complementar "instituir regiões metropolitanas, aglomerações urbanas e microrregiões, constituídas por agrupamentos de municípios limítrofes, para integrar a organização, o planejamento e a execução de funções públicas de interesse comum”.

${ }^{224}$ MENÈNDEZ, Ignacio Villaverde. La inconstitucionalidad por omisión, cit., p. 61.
} 
que a opção por uma ou outra compete a outro [órgão]"225.

Situação diversa ocorre com as normas constitucionais que dependem de necessária atuação do Poder Público para que seu conteúdo seja realmente eficaz. Para essa hipótese, insiste-se no dever de legislar. A Constituição não mais permite que o legislador (se o caso for de reserva lei, em que somente ele poderá exercer o dever normativo) atue ou não: trata-se agora de uma ordem, porquanto há a determinação de que a situação jurídica prevista pela norma realmente exista. Portanto, se o legislador, ao silenciar-se, não cumpre o que a Constituição lhe determina, ele dá azo à superveniência de uma inconstitucionalidade. Isso porque dessa norma, dita imperativa, "ao tempo que impõe a existência de uma situação jurídica por ela prevista, proíbe a existência de qualquer outra que a contradiga",226.

\subsubsection{As críticas dirigidas a cada qual}

Não se afirme que, mesmo nos países em que há a previsão de instrumentos processuais de controle da omissão inconstitucionais, esse instituto goze de reconhecimento pacífico. Tanto a corrente "obrigacionista" quanto a "normativista" enfrentaram (e ainda enfrentam) sérias dificuldades teóricas.

As principais objeções, previsivelmente, se relacionam ao princípio da separação de poderes, ao princípio democrático e à falta de segurança jurídica que esse tipo de controle pode causar. Todos esses obstáculos podem ser resumidos na seguinte afirmação: mesmo que se reconheçam algumas tarefas que a Constituição designa ao legislador, não seria possível que a jurisdição constitucional viesse a emitir um pronunciamento condenando-o a cumprí-las, em virtude de sua liberdade de conformação. Tampouco poderia substituí-lo, oferecendo ela mesma a norma faltante, dado o tradicional caráter de "legislador negativo" da jurisdição constitucional e que deve funcionar também como limite. Por conseguinte, não haveria falar-se em direito subjetivo à norma. Pensar o contrário é admitir a jurisdição constitucional como produtora de um positivismo

\footnotetext{
${ }^{225}$ MENENDEZ, Ignacio Villaverde. La inconstitucionalidad por omisión, cit., p. 61. Traduzido do original: "En último término, la norma constitucional permisiva tolera la existencia en el ordenamiento jurídico de dos posibles situaciones jurídicas, incluso antagónicas, y tan sólo establece que la opción por una u otra le compete a otro".

${ }^{226}$ MENÉNDEZ, Ignacio Villaverde. La inconstitucionalidad por omisión, cit., p. 66. Traduzido do original: "al tiempo que impone la existencia de la situación jurídica por ella prevista, prohíbe la existencia de cualquier otra que la contradiga".
} 
judiciário, o que é só autorizado constitucionalmente em poucos países ${ }^{227}$.

Se esse impedimento seria já robusto contra as normas constitucionais que demandam simples integração jurídica, pela interpositio legislatoris, tornar-se-ia irrespondível em relação às normas de cunho programático, haja vista não terem os juízes capacidade técnica ou legitimidade para tanto.

Não por outro motivo é que Manoel Gonçalves Ferreira Filho sentenciou a omissão inconstitucional como uma "falácia". Vaticina que, excluídos os casos em que a própria norma constitucional fixa um prazo certo, todas as outras que dependem de integração legislativa, por não serem completas, principalmente as programáticas, não deixam de ser "promessas constitucionais". Deixam, portanto, a cargo do legislador o momento em que tais promessas poderão ser concretizadas. Logo, a "regulamentação" judicial da norma programática viola aquela discrição do Legislativo, constituindo-se ato não democrático, pelo simples fato de que os juízes, ao contrário dos parlamentares, não foram eleitos como representantes do povo. Ademais, na medida em que as normas programáticas carecem de meios financeiros (e não só jurídicos), qualquer pronunciamento judicial que determine ao Legislativo a concretização, ou fixe-lhe um prazo para isso, terá o potencial efeito de tornar-se motivo de descrédito do próprio Poder Judiciário, pois este não conta com mecanismos sancionatórios de um eventual não atendimento daquele comando. O mesmo diga-se para os casos em que a decisão judicial exigir a edição da lei necessária, pois, neste caso, estaria o Poder Judiciário a interferir em questões políticas ${ }^{228}$.

Para a corrente normativista em especial, lastreada na evidenciação de uma norma implícita excludente, a objeção direciona-se à própria atitude da jurisdição constitucional de reconhecer essa norma implícita, e, ato contínuo, "produzir" - subrepticiamente, por lhe faltar poder normativo - ela mesma o conteúdo faltante, com o intuito de "completar" a norma interpretanda, extravasando o "simples e indolor" exercício interpretativo de colmatar as lacunas técnicas ${ }^{229}$. Consequentemente, essas sentenças de caráter aditivo acabam por incorporar-se indevidamente ao sistema de fontes, mesmo ostentando natureza jurídica diversa das leis.

${ }^{227}$ Cf. MIGUEL, Carlos Ruiz. Critica de la llamada inconstitucionalidad por omisión. Revista de las Cortes Generales. n. 51, 2001, pp. 159-177, mais precisamente, p. 166 . Disponível em http://www.iidpc.org/revistas/2/pdf/175_193.pdf. Acesso em 27/06/2013, às 15:00h.

${ }_{228}$ Cf. FERREIRA FILHO. Manoel Gonçalves. Estado de Direito e Constituição, cit., pp. 107-109.

${ }^{229}$ Cf. GUASTINI, Riccardo. Das fontes às normas. São Paulo : Quartier Latin, 2005, p. 231. 
Além disso, e considerando o argumento a rime obbligate especificamente, a jurisdição constitucional, quando "descobre" a norma que estava em estado latente no próprio ordenamento (o qual funciona como limite à atuação criativa) procede a uma escolha entre várias possíveis, o que consubstancia-se atividade do Parlamento por natureza $^{230}$. O que causa perplexidade é que "ninguém, de fato, está em condição de explicar como pode a Constituição conter normas não expressas que não são, entretanto, normas constitucionais, mas são normas legislativas",231

É digno de nota, por outro lado, o esforço em tentar superá-las, nem sempre bem sucedido, entretanto. Com efeito, ainda nos primórdios dos estudos teóricos das omissões legislativas, houve quem vaticinasse que o contorno ao problema da separação de poderes se daria pelo fato de que o "alargamento de competência" experimentado pela jurisdição constitucional seria exercido de forma subsidiária, como consequência da ausência de atividade do legislador. Isso seria justificado pelo argumento segundo o qual a razão de ser do princípio da separação de poderes seria uma melhor coordenação das funções estatais $^{232}$. De mais a mais, o legislador encontrar-se-ia livre para, a qualquer tempo, retomar o papel de concretizar a norma constitucional - o que temporariamente estava nas mãos dos juízes - e dar-lhe a configuração que reputar conforme à Constituição.

Quanto à segurança jurídica, tal princípio não pode ser considerado um fim em si mesmo, devendo ser conciliado com outras exigências fundamentais, em particular com o "princípio da justiça substancial"233.

Afirmação semelhante é a de que o princípio da separação de poderes não poderia ser mais pensado como algo rígido, considerando aplicável, esse sim, o do checks and balances, que implica o controle de um poder sobre o outro ${ }^{234}$. Imagina-se que, se tal ilação poderia legitimar o que já se encontrava pacificado há decênios (ou melhor, desde 1803), mas é duvidoso que lograsse justificar o controle da omissão legislativa, haja vista faltar a esta formulação a resposta sobre o que se entende e qual o limite desse controle recíproco.

\footnotetext{
${ }^{230}$ Cf. ZAGREBELSKY, Gustavo; MARCENÒ, Valeria. Giustizia costituzionale, cit., p. 396.

${ }^{231}$ Cf. GUASTINI, Riccardo. Das fontes às normas, cit., p. 309.

${ }^{232}$ Pensamento semelhante pode ser visto em PIÇARRA, Nuno. A separação de poderes como doutrina $e$ princípio constitucional. Coimbra : Coimbra editora, 1989, p. 262.

${ }^{233}$ Cf. TROCKER, Nicolò, Le omissioni del legislatore e la tutela giurisdizionale dei Diritti di Libertà. Studio comparativo sul diritto tedesco. Op. cit., p. 124.

${ }^{234}$ Cf. MORTATI, Costantino. Appunti per uno studio sui rimedi giurisdizionali contro comportamenti omissivi del legislatore. Op. cit., p. 934.
} 
Diz-se também que o Poder Legislativo não é mais soberano, tendo sido conduzido à função de poder constituído. Se a ele fosse concedida plena liberdade de escolha de quando (e se) emanar a legislação requerida, transformar-se-ia em poder constituinte, o que é de todo inadmissível, pois não tem o poder de dispor da Constituição ${ }^{235}$. O interessante é notar que esse mesmo argumento é utilizado pelos detratores da omissão inconstitucional. Ora, como o constituinte não fixou prazo algum para a regulamentação da maioria das normas constitucionais, ele permitiu que o legislador tomasse tal decisão quando bem assim o entendesse. Logo, qualquer tentativa de impor-lhe uma obrigação de legislar transformaria o Poder Judiciário de poder constituído a poder constituinte $^{236}$.

Pelo que se vê, a defesa teórica ou o rechaço da omissão inconstitucional, dependerá da disposição em se aceitar ou não a limitação da liberdade do legislador em formular as leis necessárias para completar a "obra” do poder constituinte.

Novamente, a posição a seguir é a do meio termo. Tudo está na definição de limites, tanto em relação à aceitação do silêncio, como para o alcance do labor jurisdicional. E esses limites atuam em duas dimensões.

A primeira se refere ao poder de sindicabilidade da jurisdição constitucional. A esta altura do estudo, parece claro que se o legislador não está pautado, temporalmente, pela norma constitucional, nem por isso pode deixar de ser censurado pela jurisdição constitucional. O cerne da questão é a definição das hipóteses em que o Parlamento (ou o Governo) tem diante de si um dever de emanar a norma. A partir desse delineamento, nem a jurisdição constitucional fica impedida de realizar o controle de constitucionalidade, nem o legislador restará constantemente ameaçado por uma sempre constrangedora decisão de inconstitucionalidade por omissão, como se pendesse sobre sua cabeça uma espada de Dâmocles. Por esse raciocínio, a separação de poderes (ou os freios e contrapesos) funciona mais como baliza do exercício de controle de constitucionalidade do que obstáculo para a sua aceitação ou autorização incondicional para o seu exercício.

A segunda dimensão diz respeito à extensão dos poderes da jurisdição constitucional. Têm razão aqueles que se opõem ao exercício do juiz constitucional em completar a norma faltante pela utilização de provimentos jurisdicionais de caráter aditivo.

\footnotetext{
${ }^{235}$ Confira-se o voto do Ministro EROS GRAU, na ADI no 2.240/BA, DJU de 02/08/2007.

${ }^{236}$ Cf. MIGUEL, Carlos Ruiz. Critica de la llamada inconstitucionalidad por omisión. Op. cit, p. 169.
} 
É notório que o controle de constitucionalidade foi pensado como uma atividade com sinal negativo, isto é, como mantenedora da coerência do sistema jurídico, pela exclusão do ato normativo que conflita com a Constituição. Mesmo no caso de controle incidental, a tarefa do juiz não é, mesmo que se atribua o escopo de maximizar a eficácia da norma, a de efetuar escolhas dentro de um universo de possibilidades. Se isso já se traduz em dificuldades para aceitação de sentenças criativas quando o objetivo é acudir o princípio da igualdade quando violado, por certo mais sérias ainda serão ainda as questões ligadas aos efeitos que o STF têm dado atualmente ao mandado de injunção.

Por isso, Juliano Zaiden Benvindo, ao citar Klaus Günther, advertiu para a diferença entre os discursos de justificação, que seria característico do Parlamento, e de adequação, típico do Judiciário. O primeiro preocupa-se com a validade da norma, mas não com a sua aplicação concreta. É dizer, volta-se ao exame em abstrato da conformidade entre os interesses e circunstâncias fáticas atuais, considerando as situações peculiares em que a norma é aplicada. Ao final, isso permitiria prever um acordo sobre a aceitabilidade universal da norma, ao pressupor que os casos em que ela é aplicável se manterão imutáveis. Esse é um discurso próprio do Legislativo porque este não se preocupa com a aplicação da norma aos casos concretos, mas dar um sentido genérico (erga omnes) à norma. A adaptação do caráter genérico da norma às situações particulares (caso concreto), em que influem outros aspectos, como as características do caso concreto e a intepretação dessa norma, é dado pelo discurso de adequação. E essa basicamente é a função do Judiciário. Assim, quando este se arvora a criar uma norma, inclusive com efeitos genéricos, incorre em perda de legitimidade, arriscando-se a abusar do critério discricionário $^{237}$.

Disso decorre que não há como concordar com o argumento segundo o qual a jurisdição constitucional, ao atuar como "legislador positivo", "completando" a lei parcialmente omissa, nada mais faz do que respeitar o trabalho do legislador, ao preservar o próprio ato normativo de autoria deste. Bem de ver que essa posição considera que é um ato muito mais grave declarar a nulidade do ato do que integrá-lo com aquilo que ele deveria ter dito $^{238}$.

${ }^{237}$ Cf. BENVINDO, Juliano Zaiden. Mandado de Injunção em Perigo: Os Riscos da Abstração de Seus Efeitos no Contexto do Ativismo Judicial Brasileiro. Observatório da jurisdição constitucional. Brasília : IDP, Ano 5, 2011/2012, pp. 13-14. Disponível em http\|www.portaldeperiodicos.idp.edu.br|índex.php|observatório|issue|current. Acesso em 19 de outubro de 2011, às 17:30h.

${ }^{238}$ Cf. ROSA, André Vicente Pires. Las Omisiones Legislativas y su Control Constitucional, cit., p. 130. 
Assim, parece ser correto afirmar que a omissão inconstitucional pode (e deve) ser declarada dentro de alguns critérios - justamente os que permitam inferir a existência de um dever de legislar - e que, de modo geral, não pode implicar uma atividade inovadora do ordenamento jurídico, como exposto acima, o que vale, inclusive, para o mandado de injunção, no caso brasileiro.

\subsubsection{A evolução e o "estado da arte" do tratamento do conceito de omissão inconstitucional no Brasil}

Historicamente, as características do tratamento das omissões constitucionais no Brasil harmonizam-se com a corrente "obrigacionista", descrita acima.

O fato é que antes ainda da promulgação do texto constitucional vigente, havia a preocupação sobre a "desvalorização da Constituição" pela inatividade "consciente" na sua aplicação ${ }^{239}$. Recaindo maior responsabilidade sobre o legislador, lamentava-se a inexistência de dispositivo constitucional que lhe impusesse sanções quando não efetivasse a Constituição ${ }^{240}$. Por isso mesmo, a preocupação era a de se criarem modos de constrangêlo a legislar.

Diante disso sugeriu-se a adoção de diversos mecanismos que pudessem dar solução ao problema das omissões legislativas, como a iniciativa popular de leis; a ampliação do alcance de remédios constitucionais; e a ação declaratória de inconstitucionalidade por omissão; a fixação de prazos, cujo descumprimento poderia motivar a edição de ato por outro poder, ad referendum do poder competente para revê-lo; a permissão dada ao Executivo para emanar "regulamento de execução com força de lei". Para as omissões do Poder Executivo, pensou-se na tipificação da eventual omissão como crime de responsabilidade, por exemplo ${ }^{241}$.

${ }^{239}$ Cf. FERRAZ, Anna Cândida da Cunha. Processos informais de mudança da Constituição. São Paulo : Editora Max Limonad, 1986, p. 218

${ }^{240}$ Cf. FERRAZ, Anna Cândida. Processos informais de mudança da Constituição, cit., pp. $72-73$ e 230.

${ }^{241}$ Cf. FERRAZ, Anna Cândida da Cunha. Inconstitucionalidade por omissão: uma proposta para a Constituinte. Revista de Informação Legislativa. Brasília : Senado Federal, ano 23, nº 89, jan/mar 1986, pp. 49, 52, 55 e 56. Para trabalhos de outros autores realizados à época da promulgação da Constituição de 1988, ver ainda: COMPARATO, Fábio Konder. Muda Brasil - uma Constituição para o Desenvolvimento Democrático. São Paulo : editora Brasiliense, 1986, pp. 614 e ss; MACHADO, Márcia Regina. Inconstitucionalidade por omissão. Revista da Procuradoria Geral do Estado de São Paulo. São Paulo : Centro de Estudos, $n^{\circ}$ 30, dez. 1988. Conquanto este artigo tenha sido publicado após a entrada em vigor da Constituição, foi escrito antes desse evento, haja fornecer subsídios doutrinários para o debate constituinte. Interessante notar que, mesmo depois da promulgação da Constituição e o não acolhimento, pela Assembleia Constituinte, da reversão de competência em prol do Poder Executivo, essa ideia foi objeto de nova proposta. 
A fixação de prazo foi desde logo criticada, dada a inutilidade da medida, uma vez que não haveria sanção possível e ser imputada ao legislador no caso de descumprimento do lapso temporal ${ }^{242}$.

Após a promulgação da Constituição Federal e o acolhimento de dois instrumentos processuais para o "combate" às omissões (legislativas e administrativas), considerando ainda a redação do artigo $102, \S 1^{\circ}$, a adesão ao modelo "obrigacionista" consolidou-se: a inconstitucionalidade por omissão depende da caracterização da mora legislativa 243 e 244 .

A ADI n ${ }^{\circ} 1.484^{245}$ é representante cristalina da visão nacional sobre o conceito de inconstitucionalidade por omissão. O trecho da decisão monocrática do relator, o ministro Celso de Mello, a seguir transcrito, mostra bem do que se está a falar:

“[o] Poder Público - quando se abstém de cumprir, total ou parcialmente, o dever de legislar, imposto em cláusula constitucional, de caráter mandatório - infringe, com esse comportamento negativo, a própria integridade da Lei Fundamental, estimulando, no âmbito do Estado, o preocupante fenômeno da erosão da consciência constitucional. - A inércia estatal em adimplir as imposições constitucionais traduz inaceitável gesto de desprezo pela autoridade da Constituição e configura, por isso mesmo, comportamento que deve ser evitado. (...)".

Desta vez, a reversão da competência de legislar se daria no contexto da federação, isto é, a unidade federativa silente poderia perder a competência para outra. O parâmetro foi o art. $12, \S \S 2^{\circ}$ e $4^{\circ}$, ADCT, que determina à União a demarcação das linhas divisórias de Estados e Municípios, casos estes não o fizessem em três anos a contar da publicação da Constituição. Cf. ROTHENBURG, Walter Claudius. Inconstitucionalidade por omissão e troca de sujeito... cit, pp. 36 e ss.

${ }^{242}$ Era essa a posição inicial de SILVA, José Afonso da. Aplicabilidade das normas constitucionais. $2^{\mathrm{a}}$ Ed. São Paulo : Saraiva, 1982, pp. 118-119, haja vista caracterizar-se como uma obrigação de natureza política e não jurídica. Posteriormente, nas edições seguintes, alterou-a, admitindo que, se a Constituição acolheu a inconstitucionalidade por omissão é porque aquela obrigação é de natureza jurídica e moral, ainda mais depois de ter havido reconhecimento jurisdicional (Cf. Aplicabilidade das normas constitucionais. $8^{\mathrm{a}}$ ed. São Paulo : Saraiva, 2012, pp. 126-127).

${ }^{243}$ Cf. PALU, Oswaldo Luiz. Controle dos atos de governo pela jurisdição. São Paulo : Editora Revista dos Tribunais, 2004, p. 22.

${ }^{244}$ Talvez, nos últimos anos, a partir da adoção de efeitos aditivos de inspiração italiana nas sentenças em mandado de injunção, tenha havido certo sincretismo com a corrente normativista. Ressalte-se que essa inovação foi expressamente reconhecida por MENDES, Gilmar Ferreira. Mandado de Injunção. DPU, nº 19,

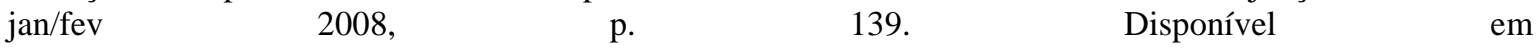
http://www.direitopublico.idp.edu.br/index.php/direitopublico/article/viewFile/387/964. Acesso em 10/04/2013, às 17:00h). Mas o mais curioso é que, mesmo que possa ser aceita essa posição, ainda hoje o dever de legislar continua profundamente arraigado tanto na doutrina como principalmente na jurisprudência - e independentemente do instrumento processual utilizado, se mandado de injunção ou ação direta de inconstitucionalidade por omissão.

${ }^{245}$ DJU de 28/08/2001. O ministro viria a reafirmar essa posição em outros julgados, como na ADI no 1442 (DJU de 29/04/2005). 
Não por outra razão é que, na jurisprudência inicial do STF, mandado de injunção e ação direta de inconstitucionalidade por omissão tiveram seus objetos e efeitos confundidos. A consequência disso é que a efetividade do uso writ foi severamente obstada, visto que não se considerava possível que o STF se substituísse ao legislador, dele não podendo esperar, também, nenhuma atitude sancionatória contra o poder omisso, como restou claro do voto do Ministro Moreira Alves, relator do MI 107QO/DF²46.

No entanto, movida pela promessa que o mandado de injunção significava, isto é, uma mudança do status quo social, a maior parte da doutrina (corroborada pelos votos de alguns ministros, ainda no MI 107, como o de Carlos Velloso ou, em outros julgados, pelos Ministros Marco Aurélio, Néri da Silveira e Sepúlveda Pertence ${ }^{247}$ ), obviamente trilhou uma senda mais proativa: o writ deveria servir para a concretização de um direito

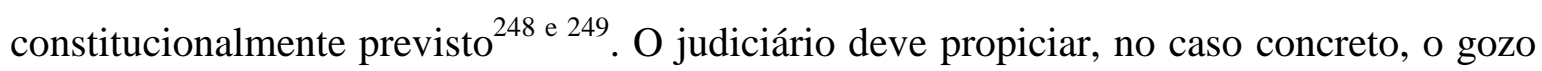
do direito, mediante o oferecimento da norma regulamentar faltante. E isso, ainda que nem sempre tivesse sido expressamente declarado, pressupõe a conservação da convicção do direito à norma ${ }^{250}$. Numa posição mais "moderna" para os tempos incipientes do estudo

\footnotetext{
${ }^{246}$ DJU de 21/09/1990. Deve ser apontado, entretanto, o posicionamento (vencido) do Ministro Celso de Mello, no sentido de que o mandado de injunção é instrumento garantidor da supremacia constitucional, aparentemente ao gosto da doutrina italiana supracitada. Isso pode ser vislumbrado no seguinte trecho de seu voto: "é preciso assinalar, no entanto, que o mandado de injunção não se destina a constituir direito novo, nem a ensejar ao Poder Judiciário o anômalo desempenho de funções normativas que lhe são institucionalmente estranhas". Mais a frente, completa seu raciocínio: "cuida-se de instrumento jurídicoconstitucional que apenas objetiva viabilizar direitos, já reconhecidos e instituídos pela própria Lei Fundamental, cujo exercício se mostra, no entanto, comprometido pela inércia normatizadora do órgão estatal inadimplente".

${ }^{247}$ Pelo menos esses ministros assim se posicionaram no MI no 20/DF (DJU 22/11/1996).

248 À guisa de exemplos: BARBI, Celso Agrícola. Supremo Tribunal Federal. Funções na Constituição Federal de 1988. Revista Forense. Rio de Janeiro, v. 85 no 308, out-dez 1989, p. 16; BARBI. Celso Agrícola. Mandado de injunção. In: TEIXEIRA, Sálvio de Figueiredo (coord.). Mandados de segurança e injunção. São Paulo : Saraiva, 1990, p. 391; MACIEL, Adhemar Ferreira. Mandado de injunção e inconstitucionalidade por omissão. In: TEIXEIRA, Sálvio de Figueiredo (coord.). Op. cit., p. 377; SILVA, José Afonso da. Mandado de injunção. In: TEIXEIRA, Sálvio de Figueiredo (coord). Op. cit., p. 399; SIDOU. J.M. Othon. Haberas corpus mandado de segurança, ação popular. As garantias ativas dos direitos coletivos. Rio de Janeiro : Forense, 1992, p. 411. A exceção a esse posicionamento sempre foi representada pelo vaticínio de FERREIRA FILHO, Manoel Gonçalves. Curso de direito constitucional. $35^{\text {a }}$ ed. São Paulo : Saraiva, 2009, p. 325.

${ }^{249}$ A posição de MODESTO, Paulo Eduardo Garrido. Inconstitucionalidade por omissão (categoria jurídica e ação constitucional específica). Revista de Direito Público, ano 24, nº 97, jan/mar 1991, pp. 224-225) merece destaque a parte. Ele também defende que o mandado de injunção possui como função a "concreção judicial", para tornar exequível ao caso concreto o direito de matriz constitucional não regulamentado. Nada obstante, ele nega que esse remédio constitucional seja um instrumento de controle de constitucionalidade por omissão, pois não é voltado ao preenchimento de lacunas, mas a preservação do direito subjetivo. Este não é, no entanto, o posicionamento amplamente majoritário da doutrina.

${ }^{250}$ Cf. ACKEL FILHO, Diomar. Writs constitucionais (habeas corpus, mandado de segurança, mandado de injunção, habeas data). $2^{a}$ ed. São Paulo: Saraiva, 1991, p. 118-119. Confira-se o item 2.6 infra.
} 
dessa ação constitucional, havia já quem defendia que o objeto do mandamus era a definição da norma regulamentadora da norma constitucional aplicável ao caso concreto ${ }^{251}$.

Seja como for, esse modo de definir a omissão inconstitucional não mudou em virtude da alteração da jurisprudência do STF para a ação constitucional em comento. Nem mesmo naqueles casos em que o Tribunal passou a integrar a norma constitucional mediante criação normativa, com efeitos da sentença inter partes (como nos julgados em que se apreciou a omissão legislativa em relação ao direito à aposentadoria especial, de que são exemplos os MIs n $721^{252}$ e $^{\mathrm{o}} 758^{253}$, ambos de relatoria do Ministro Marco Aurélio) ou erga omnes (no clássico caso do direito de greve dos servidores públicos, MIs $\mathrm{n}^{\circ}$ $670 / \mathrm{ES}^{254}, \mathrm{n}^{\mathrm{o}} 708 / \mathrm{DF}^{255}$ e $\mathrm{n}^{\mathrm{o}} 712 / \mathrm{PA}^{256}$, todos de relatoria do Ministro Gilmar Mendes), deixou de abrir mão da declaração de mora legislativa, advinda de um dever de legislar inadimplido.

Nessa altura, é mister analisar o modo como o problema da omissão legislativa inconstitucional é visto pela doutrina nacional. Normalmente, sejam os manuais sobre controle de constitucionalidade $\mathrm{e}^{257}$ ou as monografias específicas sobre o tema das

\footnotetext{
${ }^{251}$ Confira-se PASSOS, José Joaquim Calmon. Mandado de segurança coletivo, mandado de injunção, habeas data (constituição e processo). Rio de Janeiro : Forense, 1989, pp. 98-99.

${ }^{252}$ DJe 29/11/2007.

${ }^{253}$ DJe $25 / 09 / 2008$.

${ }^{254}$ DJe de 30/10/2008.

${ }^{255}$ DJe de 30/10/2008.

${ }^{256}$ DJe de 30/10/2008.

${ }^{257}$ BASTOS, Celso Ribeiro. Curso de Direito Constitucional. 22a ed. São Paulo : Malheiros, 2010, pp. 565 e 575; BERNARDES, Juliano Taveira. Controle abstrato de constitucionalidade. Elementos materiais e princípios processuais. São Paulo : Saraiva, 2004, pp. 219 e ss. Atente-se apenas para o fato de que, em relação a omissões parciais, sua tese se aproxima da construção "normativista", isto é, defende o afastamento da norma implícita, bem à moda da doutrina italiana; FERRARI, Regina Maria Macedo Nery Ferrari. Efeitos da declaração de inconstitucionalidade. $4^{\mathrm{a}}$ ed. São Paulo : Editora Revista dos Tribunais, 1999, pp. 225-228; VELOSO, Zeno. Controle jurisdicional de constitucionalidade. Belém : Cejup, 1999, pp. 274-277; DANTAS, Ivo. $O$ valor da constituição. Do controle de constitucionalidade como garantia da supralegalidade constitucional. $2^{\text {a }}$ ed. Rio de Janeiro : Renovar, 2001, pp. 72 e 138-140; RAMOS, Elival da Silva. Controle de Constitucionalidade no Brasil. Perspectivas de evolução. São Paulo : Saraiva, 2010, pp. 90-93. Num viés um pouco diverso, pois fala em lacunas constitucionais não ofensivas ao plano de ordenação constitucional, as quais seriam normas de eficácia limitada, mas sem abandonar o esquema geral acima descrito: CLÈVE. Clèmerson Marlin. A fiscalização abstrata da constitucionalidade no direito brasileiro, cit., pp. 52-53 e 324-327. Há ainda, aqueles que tratam desses instrumentos e não apresentam conceitos da omissão inconstitucional: MEIRELLES, Hely Lopes; WALD, Arnold; MENDES, Gilmar Ferreira. Mandado de segurança e ações constitucionais. 32a ed. São Paulo : Malheiros Editores, 2009, pp. 287 e ss. Outros, ainda que de modo superficial, ao tratarem da omissão inconstitucional, não fornecem nenhum tipo de conceito: SLAIBI FILHO, Nagib. Ação declaratória de constitucionalidade. 2 ed. Rio de Janeiro : editora Forense, 1995, p. 56; PALU, Oswaldo Luiz. Controle de constitucionalidade. Conceitos, sistemas e efeitos. $2^{a}$ ed. São Paulo : Editora Revista dos Tribunais, pp. 74-75 e p. 286; DIMOULIS, Dimitri; LUNARDI, Soraya. Curso de Processo Constitucional. São Paulo : Atlas, 2011, pp. 76 e 125. Estes dois últimos autores limitam-se a dizer vagamente que a inconstitucionalidade por omissão é causada pelo descumprimento duma obrigação de legislar.
} 
omissões ${ }^{258}$, os inúmeros trabalhos que cuidam dessa matéria dão nítida prioridade ao emprego dos instrumentos processuais postos à disposição pela Constituição.

Em verdade, não há maiores investigações sobre o que seria esse dever de $\operatorname{legislar}^{259}$. Aceitam-se sem mais as lições dos autores portugueses, as quais se encontram propositadamente colacionadas no tópico 2.2. Não que as lições lusitanas sejam necessariamente criticáveis, até mesmo porque demonstraram o intuito de detalhar cientificamente o tema. $\mathrm{O}$ que se quer dizer com isso é que falta curiosidade à doutrina nacional para desenvolver teoria própria sobre esse tema. Ademais, a doutrina pátria procura integrá-las a uma classificação tipológica das normas constitucionais, cuja preocupação de quem a formula conexiona-se com a demonstração do problema da aplicabilidade dessas normas. Nesse passo, é corrente a preferência pela classificação de José Afonso da Silva. Isso quando o estudioso não propõe a sua própria taxonomia.

Há, ainda, quem prefira não se aventurar a tanto, até mesmo porque questiona se a vontade política de não legislar também não seria indicativa de uma omissão inconstitucional, o que tornaria a caracterização do fenômeno como algo "complicado"260.

O resultado desse iter teórico é esse: a omissão inconstitucional decorre do descumprimento de um dever de legislar que, por sua vez, é representado por uma norma de eficácia limitada ${ }^{261}$. Até aqui, nada de extraordinário. Mas, quando se analisam esses trabalhos, ao final, a conclusão que deles se extrai é que haveria uma clara correspondência entre toda e qualquer norma constitucional de eficácia limitada (ou, na classificação

\footnotetext{
${ }^{258}$ Também sem a pretensão de citação de todos os que se interessaram pelo tema: MACHADO, Carlos Augusto Alcântara. Mandado de injunção. Um instrumento de efetividade da constituição. $2^{\mathrm{a}}$ ed. São Paulo : Atlas, 2004; PUCCINELLI JÚNIOR, André. Omissão legislativa inconstitucional e responsabilidade do estado legislador. $2^{a}$ ed. São Paulo : Saraiva, 2013, pp. 130-134; PIOVESAN, Flávia C. Proteção judicial contra omissões legislativas. Ação direta de inconstitucionalidade por omissão e mandado de injunção. São Paulo : Editora Revista dos Tribunais, 1995, pp. 78-81; CUNHA JÚNIOR, Dirley da. Controle judicial das omissões do Poder Público. São Paulo : Saraiva, 2004, pp. 118-119; PFEIFFER, Roberto Augusto Castellanos. Mandado de injunção. São Paulo : Atlas, 1999, pp. 67-69; QUARESMA, Regina. O mandado de injunção e a ação de inconstitucionalidade por omissão. Teoria e prática. $2^{\mathrm{a}}$ ed. Rio de Janeiro : Editora Forense, pp. 26 e ss. e 58; SOUZA, Luiz Henrique Boselli de. A correlação da efetividade das normas constitucionais com o suprimento das omissões normativas. Tese de doutorado. USP, 2010, pp. 29-34 e 4248; MORAES, Leonardo de. Responsabilidade por omissão do Estado. Dissertação de mestrado. USP, 2007, pp. 33 e ss.

${ }^{259} \mathrm{Um}$ dos únicos a se demorarem mais no tema é CLÈVE. Clèmerson Marlin. A fiscalização abstrata da constitucionalidade no direito brasileiro, cit., pp. 52-53 e 324-327.

${ }^{260}$ É também o caso de POLETTI, Ronaldo. Controle da constitucionalidade das leis. $2^{\text {a }}$ ed. Rio de Janeiro : Forense, 1997, pp. 216-217 e 228-230.

${ }^{261}$ Deve ser citado, como exceção, a lição de MENDES, Gilmar; COELHO, Inocêncio Mártires; BRANCO, Paulo Gustavo Gonet. Curso de direito constitucional. São Paulo : Saraiva, 2010, p. 1131, que, sob nítida influência alemã, retratam o dever de legislar como remissões explícitas ou implícitas da Constituição ao legislador. Neste último caso, o dever de legislar é extraído por exercício de hermenêutica constitucional. Esse aspecto será explorado, ainda que brevemente, na última parte desse trabalho.
} 
adotada, normas preceptivas não exequíveis por si mesmas) e a censura judicial ao legislador pelo seu silêncio. Em outras palavras, haveria uma implicação automática entre normas dessa estirpe e um dever específico de legislar: "toda norma de eficácia limitada constitui-se, desde logo, implícita ou explicitamente, numa preceptividade dirigida ao legislador ordinário, numa ordem ou mandato para que legisle para certo fim, ou num certo sentido" ${ }^{262}$. Assim, "a incompatibilidade entre a conduta positiva exigida pela constituição e a conduta negativa do Poder Público omisso configura-se na chamada inconstitucionalidade por omissão" ${ }^{263}$. Não se olvide, é certo, a dissonância doutrinária em relação às normas programáticas ${ }^{264}$. De todo modo, evidencia-se um salto argumentativo que não desperta na doutrina maiores inquietações.

É de imensa relevância salientar que, como está disposto nas obras citadas nas notas de rodapé supra, o conceito de omissão inconstitucional acaba por apresentar-se como mera peça vestibular. Menciona-se o dever de legislar como espécie de introdução de somenos importância para, logo em seguida, esmiuçar ao máximo o emprego das ações constitucionais correspondentes. Estas, sim, dissecadas em todos as suas particularidades. Assim, o que devia ser a base de uma sólida teoria da omissão inconstitucional, resume-se a um elemento acessório que orbita os instrumentos processuais que, ironicamente, encontram (ou pelo menos deveriam encontrar) nele a razão de sua existência.

Poder-se-ia argumentar que a ausência de discussão do que se entende um dever de legislar não se aplicaria ao mandado de injunção, dado o acirrado debate sobre as hipóteses de seu cabimento: se só atinente a direitos e liberdades individuais, se também para direitos sociais e econômicos ou se para todo e qualquer direito previsto direta ou indiretamente na (ou a partir da) Constituição ${ }^{265}$. Isso não deixa de ser verdade, mas também não exaure o problema da definição dos deveres de legislar.

\footnotetext{
${ }^{262}$ Cf. TEIXEIRA, J. H. Meirelles. Curso de direito constitucional, cit, p. 316.

${ }^{263}$ Cf. MORAES, Alexandre. Direito constitucional. 30ª ed. São Paulo : Editora Atlas, 2014, p. 795.

${ }^{264} \mathrm{E}$ isso vem desde a discussão na doutrina portuguesa. Como se pode ver, por todos em RAMOS, Elival da Silva. Controle de Constitucionalidade no Brasil. Perspectivas de evolução, cit., p. 92

${ }^{265}$ Sobre essa discussão, consultar: PFEIFFER, Roberto Augusto Castellanos. Mandado de injunção, cit., pp. 58-59. Conferir ainda o inventário dos posicionamentos existentes, realizado de forma bem detalhada por PÉREZ, Diego Selhane. Aspectos constitucionais do mandado de injunção. Sentido jurídico-político, direitos tutelados e efeitos da decisão. Dissertação de mestrado. São Paulo : USP, 2000, pp. 273-298, além de tabela esquemática com as principais posições interpretativas, à p. 395.
} 


\subsection{A omissão inconstitucional e suas particularidades}

\subsubsection{O direito subjetivo à norma e a correlação com a inconstitucionalidade por omissão}

Na esteira da aceitação da compreensão da omissão inconstitucional a partir do comportamento do legislador, desenvolveu-se, na dogmática constitucional pátria, a convicção segundo a qual em correspondência a um dever de legislar deve ser reconhecido um direito subjetivo à emanação da norma faltante. Na visão de quem assim pensa, esse direito torna-se ainda mais evidente diante do vasto catálogo de direitos fundamentais plasmado na Constituição Federal de 1988, e que está a exigir verdadeiras prestações estatais (materiais e normativas).

Esse entendimento é aguçado pela previsão de um instrumento processual voltado ao exercício de direitos e prerrogativas quando ausente a norma necessária para isso, como é o mandado de injunção. Na verdade, esse writ seria a prova provada de que o direito subjetivo em comento é inquestionável ${ }^{266}$.

Há quem defenda, ademais, que o direito à norma também é corolário do princípio do non liquet, visando a garantia da completude do ordenamento jurídico, pois o "juiz não pode deixar de decidir alegando ausência de lei" ${ }^{267}$. Esse é um argumento válido para a colmatação de lacunas técnicas, caso em que o juiz tem meios para integrá-la (vide art. $4^{\circ}$, do Decreto-Lei $n^{\circ} 4.657 / 42$ ). Mas, para as omissões legislativas, equivoca-se quem assim pensa ${ }^{268}$.

266 Cf. MENDES, Gilmar. Jurisdição constitucional: o controle abstrato de normas no Brasil e na Alemanha. São Paulo : Saraiva, 1999, p. 308. Defendendo o direito à norma, mas antes ainda da Constituição: GRAU, Eros Roberto. A constituinte e a constituição que teremos, cit., p. 46.

${ }^{267}$ Cf. HAGE, Jorge, Omissão inconstitucional e direito subjetivo, cit, p.72.

${ }^{268}$ Esse é um trabalho sobre a dilucidação dos deveres de legislar, fundamento para as omissões legislativas. A utilidade do detalhamento das diferenças entre lacunas e omissões legislativas seria patente se o objetivo fosse fixar premissas ou limites para a atuação de instrumentos processuais para a colmatação das omissões, como, a propósito, é feito geralmente pelos trabalhos sobre omissão inconstitucional. Diante disso, e sem negar a importância da distinção em comento, não se demorará nesse ponto. Registre, apenas, que as lacunas normativas são divisadas no âmago da norma infraconstitucional. As falhas caracterizadas como omissões inconstitucionais (mesmo as parciais) possuem, como parâmetro, a norma constitucional. Advirta-se também que a questão das lacunas é um tema recorrente na Teoria do Direito. Autores como ENGISCH, Karl. Introdução ao pensamento jurídico. Lisboa : Fundação Calouste Gulbenkian. $8^{\mathrm{a}}$ ed. 2001, especialmente pp. 281 e ss. (notar a importante diferenciação entre lacuna de lege lata e a de lege ferenda); LARENZ, Karl. Metodologia da Ciência do Direito. $3^{\text {a }}$ ed. Lisboa : Fundação Calouste Gulbenkian, 1997, especificamente pp. 540 e ss.; KELSEN, Hans. Teoria pura do direito, cit., pp. 273 e ss. 
É de ser observado que uma omissão legislativa não pode ser motivo para o juiz não julgar a demanda, mas não é fundamento para impedir que ele não a acolha ou indefira o pedido (ou julgue procedente a ação, se esse argumento tiver sido levantado pela defesa).

Pensando em termos de controle de constitucionalidade, para comprovar a debilidade dessa proposição, e para não utilizar o exemplo surrado MI 107, basta que se faça menção ao decidido pela Corte italiana na sentença $n^{\circ} 138^{269}$, que analisou o pedido de declaração de inconstitucionalidade de vários preceitos do Código Civil italiano (93, 96, 98, 107, 108, 143, 143-bis, 156-bis) "nella parte in cui, sistematicamente interpretati, non consentono che le persone di orientamento omosessuale possano contrarre matrimonio con persone dello stesso sesso". Na ocasião, um oficial do cartório de registros de pessoas naturais havia se recusado à publicar as formalidades do casamento, requeridas por um casal de homossexuais.

A Corte entendeu, contra sua própria tradição, é verdade, que o artigo $2^{\circ}$ da Constituição italiana reconhece e garante os direitos invioláveis do homem, seja como indivíduo ou inserido nas formações sociais onde desenvolve a sua personalidade. E isso implica o cumprimento de deveres inderrogáveis de solidariedade política, econômica e social. Nesse contexto, pela expressão "formações sociais" deve ser entendida toda forma de comunidade simples ou complexa, idônea a consentir e favorecer o desenvolvimento da pessoa no seu âmbito de relações, no contexto da valorização do modelo pluratístico. Por isso, as uniões estáveis homossexuais haveriam de ser consentidas como uma expressão do direito fundamental da liberdade, devendo obter, nos tempos, nos modos e nos limites estabelecidos pela lei, o reconhecimento jurídico com os consequentes direitos e deveres.

Em arremate, rejeitou a inconstitucionalidade dos artigos supracitados sob o fundamento de que a equiparação dos efeitos do casamento previsto no código civil italiano às uniões homossexuais depende de uma normativa de caráter geral e abstrata. E que isso que isso se encontra no âmbito de liberdade de conformação do legislador.

Veja-se, portanto, que a se considerar o discutível fundamento do non liquet, Corte não poderia jamais ter refutado o pedido.

\footnotetext{
269 Publicada em diário de imprensa oficial de 21/04/2010. Disponível em http://www.cortecostituzionale.it/actionSchedaPronuncia.do?anno=2010\&numero=138. Acesso em $11 / 11 / 2014$, às 16:20h.
} 
Há quem vá mais além do "simples" direito à norma. Haveria um verdadeiro direito implícito e derivado do regime previsto na Constituição (democracia "social" semidireta) e dos próprios princípios fundamentais que estariam a informar a ordem jurídico-constitucional, presentes no Título I da Carta Magna ${ }^{270}$. Disso decorreria um direito à efetivação da Constituição que seria de amplíssimo alcance, constituindo-se, basicamente, no direito de: a) exigir, na seara judicial, a fruição imediata de todo e qualquer direito ou garantia, pouco importando o reenvio da matéria da norma constitucional ao legislador ordinário, no intuito de garantir a felicidade plena do Homem; e (b) exigir à emanação de normas ou qualquer outro ato legislativo material de concretização da Constituição, em relação às normas constitucionais não definidoras de direitos e garantias ou as que contemplem direitos dependentes de interpositio legislatoris ou de providências materiais ${ }^{271}$. Em relação ao direito à emanação de normas, quem defende esse pensamento acredita que o Estado Social fez do Poder Judiciário o seu "arquiteto social", fazendo-o responsável pela concretização dos "postulados da justiça social" $" 272$.

À evidência, construções teóricas erigidas nos termos supramencionados são calcadas na desvalorização da atividade legislativa levada a efeito pelo Parlamento. A lei, e muito menos o legislador, não parecem mais ser tão necessários ao atendimento do disposto nas normas constitucionais ${ }^{273}$.

Na evolução da jurisprudência do STF atinente ao mandado de injunção, ninguém mais do que o Ministro Celso de Mello defende com maior ênfase o direito subjetivo à norma. Já no MI 20/DF ${ }^{274}$, declarou que a inércia do Estado, em matéria de falta de lei para a concretização do direito de greve em favor dos servidores públicos

\footnotetext{
${ }^{270}$ Cf. CUNHA JÚNIOR Dirley da. Controle judicial das omissões do poder público. Em busca de uma dogmática constitucional transformadora à luz do direito fundamental à efetivação da Constituição. Saraiva, 2004, p. 256.

${ }^{271}$ Cf. CUNHA Júnior, Dirley da. Controle judicial das omissões do poder público..., cit, p. 256-259.

${ }^{272}$ Cf. CUNHA Júnior, Dirley da. Controle judicial das omissões do poder público..., cit, p. 358.

${ }^{273}$ Bem de ver que isso se coaduna com o que se denominou chamar de neoconstitucionalismo. Por não fazer parte do objeto em estudo, não se pretende enveredar para a discussão teórica do que seja esse suposto novo modo de conceber o constitucionalismo e quais os seus bônus e ônus. Para uma descrição sumária das características dessa corrente teórica, consultar: MORAIS. Carlos Blanco. O controlo de inconstitucionalidade por omissão no ordenamento brasileiro e a tutela dos direitos sociais: um mero ciclo activista ou uma evolução para o paradigma neoconstitucionalista? Revista de Direito Constitucional e Internacional, ano 20, $\mathrm{n}^{\mathrm{o}} 78$, jan-mar 2012, pp. 165-166;

${ }^{274}$ DJU 22/11/96.
} 
faz emergir, em favor do beneficiário do comando constitucional, o direito de exigir uma atividade estatal devida pelo Poder Público, em ordem a evitar que a abstenção voluntária do Estado frustre, a partir desse comportamento omissivo, a aplicabilidade e a efetividade do direito que lhe foi reconhecido pelo próprio texto da Lei Fundamental.

Em julgados posteriores em que figurou como relator, pôde consolidar seu entendimento, sob a justificativa adicional de que o remédio constitucional de que se trata

busca neutralizar as consequências lesivas decorrentes da ausência de regulamentação normativa de preceitos constitucionais revestidos de eficácia limitada, cuja incidência - necessária ao exercício efetivo de determinados direitos neles diretamente fundados - depende, essencialmente, da intervenção concretizadora do legislador ${ }^{275}$.

Como consequência dessas observações, haverá o direito à legislação quando verificado descumprimento do dever estatal de emanar normas legais. É importante notar que o direito não abrange mais a norma faltante, mas alcança a própria legislação. Nada mais natural, destarte, que o Supremo Tribunal Federal faça as vezes de legislador positivo, ainda que, fora do mandado de injunção, parte de sua jurisprudência ainda negue tal condição ao Poder Judiciário ${ }^{276}$.

Foi justamente sob esse fundamento é que o STF, na viragem jurisprudencial relativa ao mandado de injunção, absorveu a obrigação de outro Poder, como se fosse dele o dever de legislar, isto é, o de emanar normas com caráter de generalidade e abstração, não mais se limitando àquela necessária para satisfazer o caso concreto $^{277}$. Essa substituição ao legislador, que à evidência não causa perplexidade a certa doutrina que a

\footnotetext{
${ }^{275}$ A gama de julgados é extensa e diz respeito a mandados de injunção apreciados sobre matérias repetitivas. Por todos: voto no MI 633/DF, DJU de 01/08/01.

${ }^{276}$ Os exemplos são inúmeros e podem ser retirados de variadas matérias. A título de exemplo: isenção tributária (RE 614.407/DF, DJe divulgado em 12/12/2014; Agravo Regimenal em RE com agravo - ARE 844.249/MG, DJe div. em 15/12/2014; ARE 810.560/SP, DJe div. em 21/11/2014; Agravo Regimental em Agravo de Instrumento - AI 831.965 AgR/RJ, DJe div. em 10/11/2014; RE 595.921 AgR/RS, DJe div. em 19/11/2014, etc.); e, sobretudo, daquelas atinentes a servidores públicos, como adicional de insalubridade (RE 565.714/SP, DJe div. em 17/11/2014; ARE 750.532 AgR/SP, DJe div. em 31/03/2014, que traz um apanhado de decisões semelhantes); súmula vinculante $\mathrm{n}^{\mathrm{o}} 4$, que diz que "salvos os casos previstos na Constituição, o salário mínimo não pode ser usado como indexador de base de cálculo de vantagem de servidor público ou de empregado nem ser substituído por decisão judicial"); e equiparação de remuneração, nos termos da Súmula n 339 .

${ }^{277}$ Veja-se a partir do MI 712, DJe divulgado em 30/10/2008.
} 
teoriza $^{278}$, parece ser cada vez mais natural, conforme se percebe pelo seguinte excerto de voto da lavra do Ministro Eros Grau:

[o] poder Judiciário, no mandado de injunção, produz norma. Interpreta o direito, na sua totalidade, para produzir a norma de decisão aplicável à omissão. É inevitável, porém, no caso, seja essa norma tomada como texto normativo que se incorpora ao ordenamento jurídico, a ser interpretado/aplicado. Dá-se, aqui, algo semelhante ao que se há de passar com a súmula vinculante, que, editada, atuará como texto normativo a ser interpretado/aplicado ${ }^{279}$.

A defesa do direito subjetivo à norma haverá que harmonizar-se com os direitos tutelados pelo mandado de injunção. Para os autores que sempre incluíram os direitos sociais e econômicos, do Título $\mathrm{II}^{280}$, ou todo e qualquer direito previsto na Constituição $^{281}$ ou que, a partir dela, se encontre no âmbito infraconstitucional ${ }^{282}$, a jurisdição constitucional deverá emanar, no mínimo, a norma regulamentadora faltante para o gozo da posição de vantagem, seja de que conteúdo for ${ }^{283}$. Afinal, o direito está de fato criado pela Constituição e esta não confere direito sem conteúdo ${ }^{284}$. Logo, a fruição da posição jurídica de vantagem não pode ficar à mercê do legislador ordinário, haja vista que ele limita-se a regulamentar as formas de exercício do direito ${ }^{285}$. A melhor solução é a que vincula o direito subjetivo à norma aos direitos fundamentais, apenas ${ }^{286}$ e desde que não

${ }^{278}$ ROTHENBURG, Walter Claudius. Inconstitucionalidade por omissão e troca de sujeito. A perda de competência como sanção à inconstitucionalidade por omissão. São Paulo : Editora Revista dos Tribunais, 2005 , p. 139 e ss.

${ }^{279}$ Voto no MI 1.034/DF, DJe divulgado. em 29/05/2009.

${ }^{280} \mathrm{Tal}$ como fazem BASTOS, Celso Ribeiro. Curso de direito constitucional, cit., p. 366; e PASSOS, José Joaquim Calmon. Mandado de segurança coletivo, mandado de injunção, habeas data (constituição e processo). Rio de Janeiro : Forense, 1989, p. 111, por exemplo.

${ }^{281}$ São representantes deste grupo José Afonso da. Mandado de injunção. Op. cit., p. 399; FERREIRA, Pinto. Comentarios à Constituição brasileira. $1^{\circ}$ volume. São Paulo : Saraiva, 1989, p. 207; FIGUEIREDO, Marcelo. $O$ mandado de injunção e a inconstitucionalidade por omissão. São Paulo : Editora Revista dos Tribunais, 1991, p. 34; HAGE, Jorge. Omissão inconstitucional e direito subjetivo. Brasília : Brasília Jurídica, 1999, p. 45; MACHADO, Carlos Augusto Alcântara. Mandado de injunção. Um instrumento de efetividade da Constituição, cit., pp. 72-74; de uma forma ambígua: SILVA, Volney Zamenhof de Oliveira. Lineamentos do Mandado de injunção. São Paulo : Editora Revista dos Tribunais, 1993, p. 55.

${ }^{282}$ Cf. MOREIRA, José Carlos Barbosa. Mandado de injunção. Revista de Processo, out-dez/89, p. 112; QUARESMA, Regina. $O$ mandado de injunção e a ação de inconstitucionalidade por omissão. Teoria $e$ prática, cit., p. 88.

${ }^{283}$ No mínimo, porque há os que sustentam que o Poder Judiciário deve propiciar o gozo do direito e não exatamente o preenchimento da lacuna. Volte-se ao que disse Paulo Modesto, supra, em nota de rodapé.

${ }^{284}$ Cf. HAGE, Jorge, Omissão inconstitucional e direito subjetivo, cit., p. 52.

${ }^{285}$ Assim pensa HAGE, Jorge. Omissão inconstitucional e direito subjetivo, cit., p. 45.

${ }^{286}$ Como assim entende RAMOS, Elival da Silva. Controle de Constitucionalidade no Brasil..., cit. p. 314 e nota de rodapé $\mathrm{n}^{\circ} 908$. 
necessitem de mais nenhuma outra providência para tornarem-se fruíveis, como, geralmente, são os direitos constantes do capítulo I, do Título II, da Constituição.

Não se olvide que foi a defesa do direito à norma faltante que motivou as críticas que foram feitas ao próprio reconhecimento das omissões inconstitucionais, as quais já foram citadas neste trabalho ${ }^{287}$. Recorde-se que, por entender vulnerado o princípio da separação de poderes e dada a impossibilidade de o STF atuar como legislador positivo, é que o tribunal levantou todos aqueles obstáculos nas primeiras sentenças em sede de mandado de injunção pelo STF e que resultaram, por anos, no atrofiamento da eficácia do próprio mandado de injunção ${ }^{288}$.

\subsubsection{O elemento temporal como possível componente da omissão inconstitucional}

É de todo evidente que, a essa altura do desenvolvimento da jurisprudência, as objeções ao reconhecimento das omissões inconstitucionais não foram capazes de suprimir a atividade de controle realizada pela jurisdição constitucional.

Mas, apesar disso, as dificuldades para a caracterização da vulneração da Constituição pelo silêncio do legislador não deixaram de existir. A elas deve ser acrescida a questão sobre o momento em que essa vulneração realmente acontece. Esse problema pode ser dividido em dois campos: quando a norma fixa prazo certo e quando não o faz.

\subsubsection{A fixação de prazo ao legislador pela própria norma constitucional}

Um ponto em que parece não haver dúvida quanto à ocorrência de inconstitucionalidade por omissão e, que, portanto, tende a convergir a doutrina sobre a ocorrência desse fenômeno ${ }^{289}$, é aquele em que a própria norma constitucional fixa prazo para o legislador emanar uma lei e ele não o cumpre. Em hipóteses desse jaez, restaria claro que a Constituição lhe impôs uma obrigação certa e, assim, não tolera de modo algum seu silêncio.

\footnotetext{
${ }^{287}$ No intuito de evitar repetições e, com isso sobrecarregar inutilmente o trabalho, remete-se o leitor para o item 2.3.3.

${ }^{288}$ Confira-se o já citado MI 107.

${ }^{289}$ Volte-se à lição de Manoel Gonçalves Ferreira Filho, no item 2.3.3.
} 
Um exemplo emblemático, que impulsionou definitivamente a jurisdição constitucional rumo ao controle dos silêncios legislativos é o conhecido art. 117, 1, da Lei Fundamental de Bonn, que fixava o dia 31 de março de 1953 para que o Parlamento procedesse à adaptação das leis vigentes ao art. $3^{\circ}, 2$, que estatui a igualdade entre homens e mulheres.

Na Constituição brasileira de 1988, normas que determinam um prazo para o legislador se concentram no Ato das Disposições Constitucionais Transitórias (ADCT) e nas Emendas que a modificaram ao longo do tempo.

Em relação aos ADCT, a amostra mais eloquente foi a fixação do prazo de cinco anos para a revisão constitucional (art. $3^{\circ}$ ). É certo que essa norma não era destinada ao legislador ordinário, mas não deixa de ser um caso importante de delimitação temporal para a atuação do Congresso Nacional.

Cite-se o disposto no art. $8^{\circ}, \S 3^{\circ}$, que determinava que uma lei, que deveria entrar em vigor no prazo de doze meses a contar da promulgação da Constituição, haveria de tratar dos casos daqueles que foram prejudicados pelas Portarias Reservadas do Ministério da Aeronáutica nº S-50-GM5, de 19 de junho de 1964, e nº S-285-GM5, devendo assegurar-lhes uma indenização. Como se sabe, tal dispositivo foi objeto de mandados de injunção, como o MI nº 283/DF.

Igualmente, devem ser lembrados os arts. $29, \S 1^{\circ}$, que dava o prazo de 120 dias para que o Presidente da República encaminhasse ao Congresso Nacional projeto de lei complementar dispondo sobre a organização e o funcionamento da Advocacia-Geral da União; o art. 39, parágrafo único, que impunha o prazo de doze meses para que o Congresso Nacional legislasse sobre a forma de rateio da receita da União sobre o Imposto de Rendas, IPI e CIDE, assim como definir critérios de participação de Estados e Municípios nos correspondentes fundos, como determinado pelo art. 161, II. Saliente-se que a lei exigida foi editada: lei complementar $n^{\circ}$ 62/89. Entretanto, foi objeto das ADIs $n^{\circ}$ 875/DF, 1.987/DF, 2.727/DF e 3.243/DF, que julgaram inconstitucionais os incisos I e II, $\S \S 1^{\circ}, 2^{\circ}$ e $3^{\circ}$, e do Anexo Único, da Lei Complementar n. ${ }^{\circ}$ 62/1989, assegurada a sua aplicação até 31 de dezembro de 2012. O vácuo legislativo formado a partir dessa data, motivou a interposição da Ação Direta de Inconstitucionalidade por Omissão (ADO) $\mathrm{n}^{\circ}$ 23/DF. 
$\mathrm{O}$ artigo 50 determinava por sua vez que uma lei deveria ser promulgada no prazo de um ano da promulgação da Constituição e teria que dispor sobre os objetivos e instrumentos de política agrícola, prioridades, planejamento de safras, comercialização, abastecimento interno, mercado externo e instituição de crédito fundiário.

Não se olvide, finalmente, a exigência contida no art. Art. 48, pela qual o Congresso deveria elaborar, dentro de cento e vinte dias da promulgação da Constitução, o código de defesa do consumidor, lei que só veio a ser publicada em 11 de setembro de 1990.

Em relação às Emendas, listem-se os arts. 27 e 30, da Emenda Constitucional no 19/98, que atribuíram, respectivamente, o prazo de cento e vinte dias contados a partir de sua promulgação para que o Congresso Nacional elaborasse a lei de defesa do usuário de serviços públicos e o prazo cento e oitenta dias, também contados a partir da promulgação da Emenda, para que o Poder Executivo apresentasse ao Congresso Nacional o projeto de lei complementar a que se refere o art. 163 da Constituição Federal e que culminou com a edição da lei complementar no 101/2000 (lei de responsabilidade fiscal), sendo que o primeiro artigo mencionado já é objeto da $\mathrm{ADO} \mathrm{n}^{\circ} 24 / \mathrm{MC}$; o art. $7^{\circ}$, da Emenda Constitucional $n^{\circ}$ 20/98, que fixou o prazo de noventa dias a contar da data da publicação da Emenda para que fossem apresentados ao Cogresso Nacional os projetos das leis complementares sobre previdência privada complementar, e que foram previstas no art. 202, da Constituição Federal; o art. $7^{\circ}$ da Emenda Constitucional n $n^{\circ}$ 45/2004 preconizava que “o Congresso Nacional instalará, imediatamente após a promulgação desta Emenda Constitucional, comissão especial mista, destinada a elaborar, em cento e oitenta dias, os projetos de lei necessários à regulamentação da matéria nela tratada, bem como promover alterações na legislação federal objetivando tornar mais amplo o acesso à Justiça e mais célere a prestação jurisdicional".

Nada obstante, nem toda norma que fixa um prazo será apta a fundamentar uma inconstitucionalidade por omissão, se descumprido pelo legislador. Este assunto, entretanto, será objeto do capítulo seguinte deste trabalho.

\subsubsection{Interpositio legislatoris sem fixação de prazo pela norma constitucional}


O problema é que as normas que portam consigo a fixação de um prazo certo são minoria. Por isso, para parcela importante da doutrina e da jurisprudencia, a passagem do tempo é indissociável do próprio dever de emanar a norma exigida pela Constituição ${ }^{290}$. A omissão legislativa inconstitucional seria, ao fim e ao cabo, o resultado da conjugação desses dois elementos. Por conseguinte, levando-se em consideração o tipo de norma constitucional, as situações da vida e a "natureza das coisas", caberia ao órgão jurisdicional avaliar dentro, de um "tempo histórico", se a norma infraconstitucional exigida já não poderia ter sido produzida pelo legislador ${ }^{291}$. Essa perspectiva é relevante para a justificação do próprio controle de constitucionalidade. Para isso, desenvolveu-se o que se denominou de teoria do prazo razoável ${ }^{292}$.

A avaliação do que seria um prazo razoável dependeria da natureza da norma constitucional a servir de parâmetro para a declaração da inconstitucionalidade por omissão. Assim, para as normas preceptivas não exequíveis por si mesmas, que dependem basicamente da mera atuação do legislador, e não de outros requisitos metajurídicos, como as programáticas, o constituinte não lhe teria deixado liberdade plena para definir o momento da produção da norma conformadora ${ }^{293}$. Essas normas deveriam ser integradas no menor espaço de tempo possível. Para as normas programáticas, ao contrário, o prazo razoável a ser observado seria naturalmente mais longo, tendo em vista as suas evidentes peculiaridades. Para essas normas, é pela passagem mais longa de tempo que se poderia concluir que as contingências da realidade econômica, social e cultural não seriam capazes de levar ao legislador a tomar uma decisão que leve a resultados impossíveis ${ }^{294}$.

\footnotetext{
${ }^{290}$ Quanto aos estudiosos nacionais, não há a necessidade de se prolongar na citação de todos eles sobre o tema. Por todos: RAMOS, Elival da Silva. Controle de Constitucionalidade no Brasil. Perspectivas de evolução, cit., p. 93. As exceções são representadas por ROSA, André Vicente Pires. Las omisiones legislativas y su control constitucional, cit., pp. 148 e 149; e BERNARDES, Juliano Taveira. Controle abstrato de constitucionalidade, p. 219.

${ }^{291}$ É a conhecida lição de MIRANDA, Jorge. Curso de Direito Constitucional. Tomo VI. Combra : Coimbra editora, 2008, p. 322. Na doutrina portuguesa, há uma clássica dissensão entre este autor, de um lado, e J J. Gomes Canotilho e Vital Moreira, de outro. O tempo histórico defendido pelo primeiro é refutado por estes, tendo em vista que não compete ao Tribunal Constitucional "apreciar a questão do tempo ou a oportunidade da medida legislativa”. Cf. CANOTILHO, J J Gomes; MOREIRA, Vital. Constituição da República portuguesa anotada. $2^{\mathrm{a}}$ ed. Coimbra : Coimbra editora, 1984, p. 1.048.

${ }^{292}$ Cf. SEGADO, Francisco Fernandez. El control de constitucionalidade de las omisiones legislativa. Algunas cuestiones dogmáticas. Op. cit., p. 34.

${ }^{293}$ Cf. SILVA, Jorge Pereira da. Dever de Legislar e protecção jurisdicional contra omissões legislativas, cit, p. 160. Esse autor reputa que a regulamentação dessas normas pelo legislador seja de fato prioritária, inclusive com previsão expressa nos Regimentos das Casas Legislativas.

${ }^{294}$ SILVA, Jorge Pereira da. Dever de legislar e protecção jurisdicional contra omissões legislativas..., cit., p. 12. Também nesse sentido: MORAIS, Carlos Blanco. Justiça Constitucional. Tomo II. O contencioso constitucional português entre o modelo misto e a tentação do sistema de reenvio, cit., pp. 469 e 479-480; RODRIGUEZ, Jose Julio Fernandez. La incostitucionalidad por omisión..., cit., pp. 85-86, que fala em "tempo excessivo", causador da "fraude constitucional".
} 
Pelo que se viu até agora, o tempo razoável tem uma importância maior quando não existe ainda uma lei que dê conformação à norma constitucional. À evidência, quando se trata de discriminações normativas lesivas ao princípio da igualdade, o que pode caracterizar uma omissão relativa, como se verá abaixo, o tempo perde toda a relevância. E, por coerência da linha "normativista", de tradição italiana, pela qual a jurisdição constitucional deve afastar a norma implícita negativa e inconstitucional causada pela atividade legislativa insuficiente, fornecendo então a parte "faltante" e completando a norma, o prazo é elemento certamente dispensável.

Para essa corrente, a falta de fixação de prazo pela própria norma constitucional deve ser interpretada como mera permissão ao legislador para que seja ele quem escolha sobre o momento oportuno para desincumbir-se de seu mister ${ }^{295}$. Não seria, então, a jurisdição constitucional o órgão a escolher a partir de que momento a norma constitucional deixa a inércia eficacial e passa estar apta a produzir efeitos ${ }^{296}$. De consequência, o prazo pertence ao mundo da decisão política, e não o da decisão jurídica, sendo que a "teoria do prazo razoável" teria como fundamento (equivocado) amenizar os efeitos da sentença que as reconhece. Isso porque, em casos dessa natureza, o juiz evita a anulação do preceito omisso, recomendando ao legislador que, dentro de um prazo, sane o defeito legal. Essa atitude torna precária a validade da lei impugnada como omissa, desaguando num exercício espúrio de política legislativa ${ }^{297}$. É por isso mesmo que a decisão de não legislar não tem relevância jurídica, mas política ou sociológica, como assentado no item 2.3.2.

Certamente o argumento segundo o qual o reconhecimento de um prazo razoável, seja pela passagem do tempo ou pela fixação pelo próprio juiz, pode implicar exercício de política legislativa é deveras poderoso. Talvez seja até irrespondível para aqueles casos de norma de textura muito aberta, como ocorre com as programáticas, de que é exemplo o caput do artigo $6^{\circ}$ da Constituição Federal de 1988. Não se pode olvidar que essas normas demandam fatores metajuridicos, como recursos financeiros e materiais. Além disso, exigem o estabelecimento de consenso numa escala muito maior do que a verificável para outras normas que demandam a criação de um órgão ou o regramento de um serviço. Logo, mesmo que delas se extraiam um dever de legislar, este dever não será concreto, mas simplesmente vago e abstrato.

\footnotetext{
${ }^{295}$ MENÈNDEZ, Ignacio Villaverde. La inconstitucionalidad por omisión, cit, p. 42.

${ }^{296}$ Relembre-se a lição de Manoel Gonçalves Ferreira Filho, no item 2.3.3, supra.

${ }^{297}$ MENÈNDEZ, Ignacio Villaverde. La inconstitucionalidad por omisión, cit, pp. 43-44.
} 
Por outro lado, não se compartilha da posição que somente reconhece a inconstitucionalidade por omissão quando a Constituição assim o diga, ou seja, quando ela mesma determinar um prazo para que o legislador edite a lei necessária. Igualmente, por motivos óbvios, é absurdo julgar inconstitucional o comportamento omissivo do legislador em não proceder à concretização das normas constitucionais imediatamente após a promulgação de uma Constituição. Logo, o prazo razoável haverá que ser levado em conta para a caracterização da omissão inconstitucional, para as normas que não deixam larga margem de manobra ao legislador e em sendo respondido afirmativamente que elas (ou algumas delas) correspondem a um dever de legislar controlável pela jurisdição constitucional.

Se no campo teórico há acesa discussão nesse tema, quando se analisa a jurisprudência que lhe é pertinente, conclui-se com facilidade que a jurisdição constitucional europeia (salvo a portuguesa ${ }^{298}$ ) e também o STF não consideraram de interesse prático essa discussão.

Registre-se também que, para os Tribunais, o tempo não é balizador tãosomente da configuração das omissões inconstitucionais, entendido como fenômeno consolidado. O Tribunal Constitucional Federal alemão utiliza técnicas decisórias como o apelo ao legislador (Appellentscheidung) e a declaração de inconstitucionalidade sem pronúncia de nulidade, como elementos de "diálogo institucional" para evitar que situações ainda constitucionais (situações constitucionais imperfeitas) não se transformem em infrações à Constituição. A partir dessas técnicas, o Tribunal exorta o legislador a corrigir deficiências encontradas na lei. Eventualmente pode até mesmo fixar um prazo para que o legislador assim o faça, de modo que o apelo é convertido em obrigação ${ }^{299}$, que, conquanto

\footnotetext{
${ }^{298}$ O Tribunal Constitucional português trouxe para dentro de seus julgados a dissensão teórica havida entre J. J. CANOTILHO e JORGE MIRANDA, apresentada acima. Para tanto, conferir: MORAIS, Carlos Blanco. Justiça Constitucional. Tomo II. O contencioso constitucional português entre o modelo misto e a tentação do sistema de reenvio, cit, pp. 477-479; SILVA, Jorge Pereira da. Dever de Legislar e protecção jurisdicional contra omissões legislativas..., cit., pp. 158-161.

${ }^{299}$ Cf. MENDES, Gilmar Ferreira. O apelo ao legislador na Corte Constitucional alemã. Revista Trimestral de Direito Público. São Paulo : Malheiros Editores, n 10, 1995, pp. 32-33; SEGADO, Francisco Fernandéz. El control de las omisiones legislativas por el "Bundesverfassungsgericht". Op. cit., p. 110 e ss.; GERHARDT, Michael. Problems of legislative omission in the Federal Constitutional Court's case law. In Report by the Federal Constitutional Court for the XIVth COngress of European Constitutional Courts, 2008, p. 41 e 43. Disponível em http://www.confeuconstco.org/reports/rep-xiv/report_Germany_en.pdf. Acesso em 20/08/2013, às 09:00h; BEILFUSS, Markus González. Tribunal Constitucional y reparación de la discriminación normativa, cit., pp. 300-302.
} 
não o obrigue juridicamente, torna a permanência da inatividade uma situação institucionalmente errônea ${ }^{300}$.

Num contexto semelhante, o Tribunal Constitucional espanhol, sobretudo em se tratando de discriminação normativa (omissão parcial) deixa de lado a mera possibilidade de anular o preceito discriminatório, aduzindo que o legislador colmate a omissão verificada "dentro de um prazo razoável”, ou "no prazo mais breve possível", sem, no entanto, fixar um prazo. Realmente, na STC 96/1996, julgou o Tribunal que "a tarefa legislativa que corresponde às Cortes [ao Poder Legislativo] deve ser levada a termo dentro de um prazo de tempo razoável e, evidentemente, deve respeitar a ordem constitucional de competências na matéria, cuja garantia fique confiada, em último caso, à função de controle que corresponde a este Tribunal" ${ }^{301}$.

Em outra ocasião, entendeu que "é ao legislador a quem corresponde, no uso de sua liberdade de conformação normativa própria de sua potestade legislativa, remediar a situação [omissiva] completando o preceito legal. Como dissemos em outras ocasiões, ainda que certamente para efeitos diferentes dos que aqui contemplados, essa situação [de omissão inconstitucional] deve acabar o quanto antes, sendo função da tarefa legislativa das Cortes [Poder Legislativo] colocar-lhe um termo no prazo mais breve possível". ${ }^{302}$

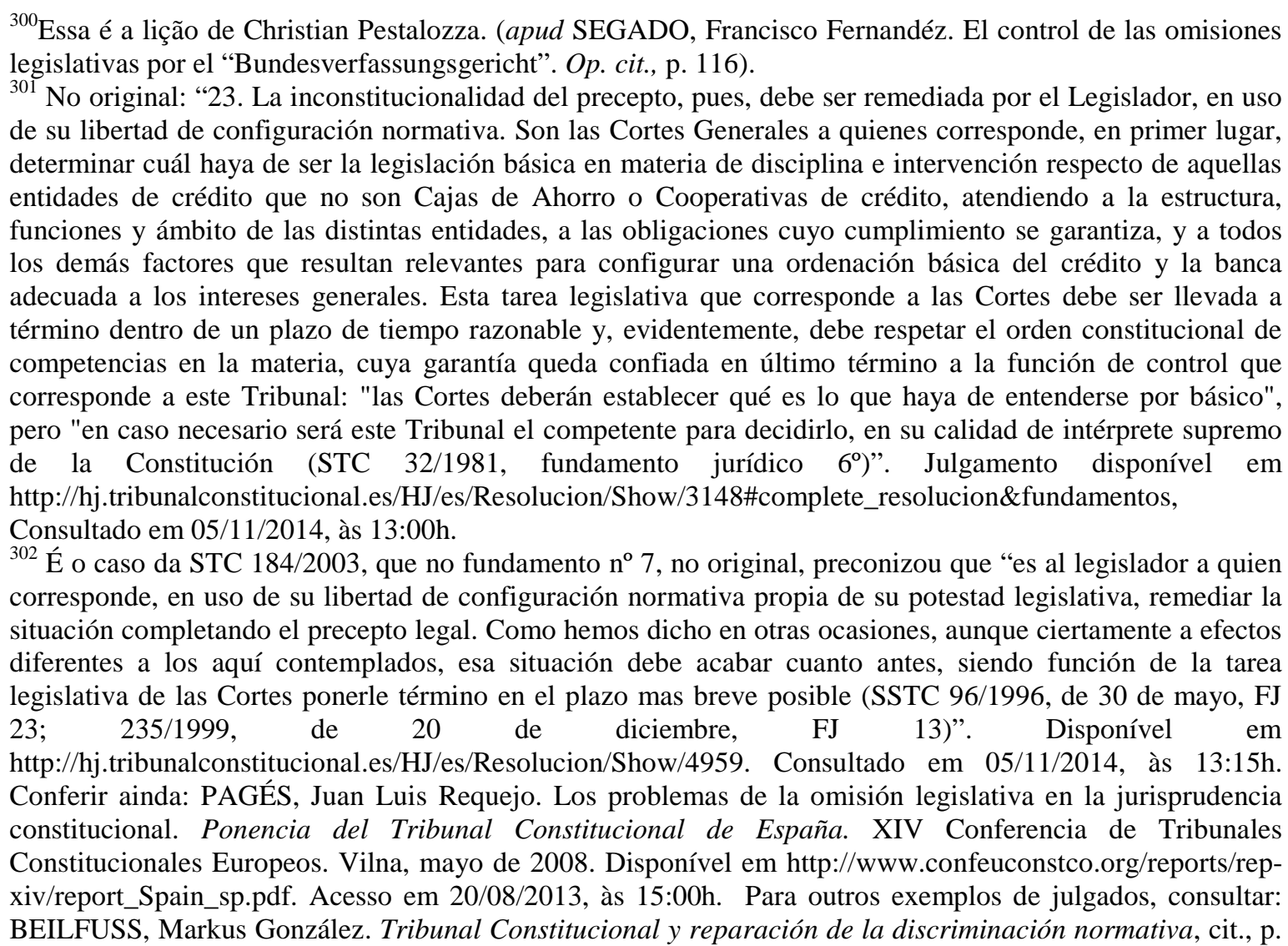


Na Itália, como se viu, as decisões de cunho aditivo não levavam o tempo em consideração $^{303}$. Somente com o avanço da jurisprudência e a adoção de novas técnicas de decisão, como as sentenças de princípio, em que se percebe uma aproximação ao modelo alemão do diálogo com o legislador, o tempo parece ganhar alguma relevância, porquanto a Corte julga certa lei como ainda constitucional, mas que prestes a tornar-se inconstitucional e lhe envia uma "advertência" a evitar a inconstitucionalidade ou mesmo saná-la. Se o legislador não atendê-la, numa próxima oportunidade de controle a Corte será obrigada a anular a lei ${ }^{304}$.

No Brasil, o STF, certamente bebendo também da fonte alemã, dá importância ao tempo sob aqueles dois aspectos: ou (a) simplesmente, mediante a constatação de uma omissão legislativa, afirma que passou um tempo suficiente para que o órgão legislativo emitisse a norma reclamada, declarando, por consequência, a inconstitucionalidade ${ }^{305}$; ou (b) órgão jurisdicional fixa prazo ao legislador para que ele cumpra seu dever de legislar.

Essas duas possibilidades são demonstráveis, tanto em sede de mandado de injunção, como em controle abstrato. Antes disso, porém, cumpre deixar assente a existência de alteração de entendimentos. Nos primeiros julgados de mandado de injunção (notadamente os MIs $n^{\mathrm{o}} 168^{306}$ e $\mathrm{n}^{\mathrm{o}} 188^{307}$, ambos de relatoria do Ministro Sepúlveda Pertence), o Tribunal compreendia, na voz do relator das ações, que o pedido "possível" a ser deferido limitava-se à ciência ao Congresso Nacional da omissão verificada.

Exemplos da primeira possibilidade são facilmente encontráveis, podendo ser feita uma subdivisão: ou o Tribunal reconhece que transcorreu o prazo razoável desde a apreciação de idêntico caso anterior, em que inclusive foi cientificado o Congresso com a fixação prévia de prazo (o que ocorreu no MI no 284/DF ${ }^{308}$, em relação ao MI no 283/DF)

301. O Tribunal teria, nas STC 216/91 e 31/94, considerado que a omissão inconstitucional é caracterizada também pela demora do legislador na regulação de uma determinada situação jurídica. É o que diz MENENDEZ, Ignácio Villaverde. La inconstitucionalidad por omisión, cit., p. 43.

${ }^{303}$ Ver item 2.1.2.2

${ }^{304}$ Cf. ZAGREBELSKY, Gustavo; MARCENÓ, Valeria. Giustizia costituzionale, cit., p. 402.

${ }^{305}$ Cf. RAMOS, Elival da Silva. Controle de Constitucionalidade no Brasil. Perspectivas de evolução cit., p. 93. Registre-se, por oportuno, o ocorrido com as ADIs no 1987/DF, no 875/DF, no 2.727/DF, n 243/MT, julgadas em conjunto (DJe 29/04/2010, relator Ministro Gilmar Mendes). Ao considerar a fungibilidade entre as ações declaratórias de inconstitucionalidades por ação e por omissão, o Tribunal considerou que a demora para a emissão de nova lei complementar que fornecesse novos critérios para o cumprimento do disposto no artigo 161, II, da Constituição Federal, conduzia a uma inconstitucionalidade parcial da lei complementar $\mathrm{n}^{\circ}$ 62/89. No entanto, o Tribunal, ao declarar a inconstitucionalidade referida, deixou de anular a lei, mantendo a sua vigência até 31 de dezembro de 2012.

${ }_{306}$ DJU de $20 / 04 / 1990$.

${ }^{307}$ DJU de 22/02/1991.

${ }^{308}$ DJU de 26/06/92 (relator Ministro Marco Aurélio Mello). 
ou mesmo sem isso (MIs n ${ }^{\circ}$ s 323/DF ${ }^{309}$, para a regulamentação da taxa de juros prevista no então vigente art. 192, $\S 3^{\circ} ; 670 / \mathrm{ES}, \mathrm{n}^{\circ} 708 / \mathrm{DF}$ e $\mathrm{n}^{\mathrm{o}} 712 / \mathrm{PA}$, em relação ao direito de greve dos servidores públicos, já apreciado nos MIs $n^{\text {o }}$ 20/DF ${ }^{310}$, no 438/GO ${ }^{311}$, no 485/MT ${ }^{312}$ e $\mathrm{n}^{\circ} 585 / \mathrm{TO}^{313}$ ), ou estatui que houve a decorrência de prazo razoável em prol do legislador, que permaneceu silente, caracterizando a inconstitucionalidade (MIs $n^{\text {o }}$ 361/RJ ${ }^{314}$, juros reais, e $\mathrm{n}^{\mathrm{o}} 721 / \mathrm{DF}^{315}$, aposentadoria especial).

Quanto à segunda hipótese, firme no tratamento da omissão legislativa como mora a ser declarada, posteriormente, nos MIs n ${ }^{\mathrm{o}} 283 / \mathrm{DF}^{316} \mathrm{e} \mathrm{n}^{\mathrm{o}} 232 / \mathrm{RJ}^{317}$, o Tribunal saiu de posição inicial de simplesmente comunicar o Congresso sobre a sua inadimplência de um dever de legislar. Reconheceu a situação de mora, fixando-lhe prazo para o cumprimento de sua obrigação. Além disso, determinou que, descumprido o lapso atribuído, as normas constitucionais objetos dos pedidos tornar-se-iam de aplicabilidade direta (no primeiro caso, autorizou que os interessados ingressassem na justiça ordinária para pleitearem a quantificação da indenização devida pelo art. $8^{\circ}, \S^{\circ}$, ADCT; no segundo, fariam jus à imunidade tributária prevista no art. $195, \S 7^{\circ}$ ).

Cumpre, ainda, fazer menção a dois julgados em especial, representativos da prática de atribuição de prazo ao legislador, desta vez, em julgamento de ação direta de inconstitucionalidad por omissão.

Em primeiro lugar, assinale-se a decisão monocrática proferida na $\mathrm{ADO} \mathrm{n}^{\mathrm{o}} 24-$ $\mathrm{MC}^{318}$, cujo fundamento era o previsto no artigo 27, da Emenda Constitucional no 19/98. Como se sabe, o preceito fixava prazo de 120 dias para que o Congresso votasse a lei de defesa dos usuários de serviço público, o que acabou não acontecendo. O relator, em decisão monocrática, declarou a mora do Congresso e fixou prazo de mais 120 dias para que isso acontecesse.

\footnotetext{
${ }^{309}$ DJU de 09/12/94 (relator Ministro Moreira Alves).

${ }^{310}$ DJU de 22/11/1996 (relator Ministro Celso de Mello).

${ }^{311}$ DJU de 16/06/1995 (relator Ministro Néri da Silveira).

312 DJU de 23/08/2002 (relator Ministro Maurício Corrêa).

${ }^{313}$ DJU de 02/08/2002 (relator Ministro Ilmar Galvão).

${ }^{314}$ DJU de 23/06/93 (relator Ministro Néri da Silveira).

${ }^{315}$ DJU de 30/11/2007 (relator Ministro Marco Aurélio Mello).

${ }^{316}$ DJU de 14/11/1991 (relator Sepúlveda Pertence).

${ }^{317}$ DJU de 27/03/1992 (relator Ministro Moreira Alves).

${ }^{318} \mathrm{DJ} e$ divulgado em 01/08/2013.
} 
Chama a atenção, da mesma forma, a solução encontrada pela Corte no julgamento da ADI no 3682/MT ${ }^{319}$. O Tribunal julgou inconstitucional a omissão quanto a não edição da lei requerida pelo art. $18, \S 4^{\circ}$, alterada pela Emenda $n^{\circ} 15 / 96$. Entendeu que a passagem de mais de dez anos desde a promulgação da referida Emenda era tempo mais que razoável para o atendimento daquela norma constitucional. O que é digno de nota, e que causa certa perplexidade, é que o relator, Ministro Gilmar Mendes, ao entender que "não se pode afirmar, (...), que a decisão que constata a existência da omissão inconstitucional e determina ao legislador que empreenda as medidas necessárias à colmatação de lacunas não produz maiores alterações na ordem jurídica" e que, por isso, a sentença que a reconhece "tem caráter nitidamente mandamental”, impondo ao legislador em mora o dever, dentro de um prazo razoável, de fulminar a inconstitucionalidade, fixou o prazo de dezoito meses para que o legislador adotasse as medidas legislativas cabíveis. Nada obstante, ato contínuo, em movimento contraditório, que talvez demonstrasse certo pudor, ele negou que isso significasse imposição de prazo. Tratar-se-ia de uma adequação ao prazo estipulado de 24 meses estipulado pela Corte em ADIs anteriores (ADIs $n^{\circ} 2.240$, 3.316, 3.489 e 3.689), que tiveram como objeto leis estaduais ciradoras de municípios sem o parâmetro legislativo federal.

A questão óbvia que os julgados despertam - a propósito, posta pelo Ministro Marco Aurélio na ADI n 3682 - incide sobre a utilidade da fixação de prazo. Num raciocínio confuso, a possibilidade da adoção de prazo foi defendida pelo Ministro Carlos Britto: uma vez que o comando constitucional que tratou da omissão inconstitucional não estipulou prazo para o legislativo, mas só para a autoridade administrativa, significava que o Tribunal não se achava limitado pela norma constitucional.

A resposta dada ao problema, contudo, não elide a dúvida sobre quais seriam os mecanismos que vinculariam o Parlamento a decisões desse naipe. Muito menos quais as sanções que aquele deveria experimentar em decorrência de eventual descumprimento da medida, caso se entenda que de obrigação se trata, além, é claro, do constrangimento político que já é inerente à própria declaração de inconstitucionalidade por omissão. Esse "nó górdio" pode ser encarado no contexto de um diálogo institucional - à moda da práxis inicial alemã - em que a preocupação não é (nem poderia ser) a imposição de sanções, mas reforçar a cooperação entre instâncias decisórias, o que, no limite, não é garantia de cumprimento do prazo pelo legislador. Mas o fato é que o Tribunal pode também sofrer um

${ }^{319}$ DJe divulgado em 05/09/2007 (relator Ministro Gilmar Mendes). 
constrangimento, caso o Parlamento não cumpra o teor da cooperação ou obrigação, hipótese em que se reforçaria a tese da perda de autoridade do Poder Judiciário.

A alternativa à frustração do comando jurisdicional pelo legislador, mantida a situação de omissão legislativa, talvez seja o ingresso em juízo por aquele prejudicado pela falta de lei, em busca de uma compensação financeira pelo não exercício de um direito criado pela Constituição ${ }^{320}$. No Brasil, nada obstante, essa solução vem sendo rechaçada pelo $\mathrm{STF}^{321}$.

\subsubsection{As qualificações do descumprimento do dever específico de legislar. Os tipos de omissões inconstitucionais}

Os deveres específicos de legislar, quando descumpridos, podem motivar, segundo a doutrina e jurisprudência, omissões inconstitucionais que se apresentam sob múltiplas formas. Diante disso, costuma-se apresentar diferentes critérios para uma disposição classificatória, que vão desde a existência ou não da lei exigida pela Constituição, passando pelo grau de atendimento da norma constitucional, pela natureza da norma e até a verificação se podem ser colmatadas ou não.

Para além do interesse acadêmico, a tipologia das omissões inconstitucionais revela a complexidade do próprio fenômeno também em seus aspectos práticos. Em algumas ocasiões, as inconstitucionalidades por omissão e por ação parecem mesmo se confundir, a ponto de certos autores defenderem a colmatação da omissão a partir de técnicas de decisão próprias da fiscalização da inconstitucionalidade comissiva. Não é o caso, contudo, de negar a existência de diferenças entre essas modalidades de inconstitucionalidade, mormente na seara da proteção do princípio da igualdade, como fazem alguns ${ }^{322}$.

\footnotetext{
${ }^{320}$ Nesse sentido: TAVARES, André Ramos. Tribunal e jurisdição constitucional. São Paulo : Celso Bastos editor, 1998, p. 139.

${ }^{321}$ Conferir: RE 424.584/MG (DJe divulgado em 06/05/2010, relator Ministro Carlos Velloso e, para o acórdão, Ministro Joaquim Barbosa). Atente-se ao voto do Ministro Gilmar Mendes, que cita diversos outros julgados no mesmo sentido.

${ }^{322}$ É o caso de Juan Luis Requejo Pagés, em relação ao principio da igualdade. Este autor entende que a qualificação da inconstitucionalidade como omissiva ou comissiva, no limite, dependerá somente da interpretação que dela fizer a jurisdição constitucional sobre a discriminação verificada. Nesse caso, o tratamento desigual ou se converte num plus indevido a uma categoria ou numa exclusão não permitida de outras categorias que se encontrem na mesma situação jurídica daquela contemplada. Isto é, tanto num caso como em outro haverá uma nulidade que pode ser declarada pelo Tribunal (Cf. PAGÉS, Juan Luis Requejo. Constitución y remisión normativa. Perspectivas estática y dinámica en la identificación de las normas constitucionales. Revista Española de Derecho Constitucional, 1993, nº 39, p. 151).
} 
Para o escopo desse trabalho, interessam as categorias mais comuns, que serão abaixo detalhadas. Seguindo esse plano, uma classificação corriqueira e que acompanha a inconstitucionalidade por omissão desde os estudos pioneiros que a tiveram como objeto $^{323}$, é a que a divide de acordo com a intensidade do descumprimento do dever de legislar.

São totais as omissões que decorrem da vulneração completa da norma constitucional, isto é, para a qual não há nenhuma lei que garanta a sua aplicabilidade. Certamente, é nesse campo que a jurisprudência do STF é mais farta, como se pode perceber dos julgados citados nos itens precedentes.

Por outro lado, são parciais as omissões que decorrem do desenvolvimento incompleto ou não satisfatório do dever expresso na norma constitucional ${ }^{324}$. $\mathrm{Na}$ omissão parcial, existe a lei demandada, mas o conteúdo desta é insuficiente para regular a norma constitucional em sua inteireza. Há quem afirme que pouco importa se a insuficiência mencionada se dá por uma equivocada interpretação das normas constitucionais que estabelecem o dever de legislar, pela avaliação de circunstâncias fáticas, pela não consideração de certos grupos ou categorias de pessoas ou pela mera intenção do legislador $^{325}$.

Na jurisprudência do STF, não são tão frequentes exemplos de declaração de inconstitucionalidade por omissão parcial. O Tribunal sinalizou pela ocorrência desse tipo de omissão na legislação que fixava o salário mínimo em valor insuficiente para o disposto no artigo $7^{\circ}$, IV, da Constituição Federal, nas ADIs $n^{\circ} 1.439-\mathrm{MC}^{\circ} \mathrm{DF}^{326}$ e 1.458 -

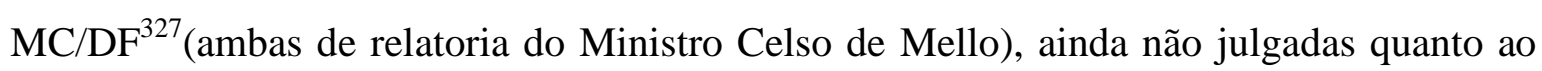
mérito. Na Rcl 4.374/PE ${ }^{328}$, declarou a omissão parcial em relação ao artigo art. $20, \S 3^{\circ}$ da Lei $8.742 / 1993^{329}$.

\footnotetext{
${ }^{323}$ Confira-se o item 2.1.2 supra sobre o pioneirismo de Wessel em se tratando de catalogação dos tipos de omissões inconstitucionais. Ele na verdade trata as omissões totais como absolutas e as parciais como relativas.

${ }^{324}$ Cf. ROSA, André Vicente Pires. Las omisiones legislativas y su control constitucional, cit, p. 151.

${ }^{325}$ Cf. SILVA, Jorge Pereira da. Dever de legislar e protecção jurisdicional contra omissões legislativas.., cit, p. 89. O autor considera ainda que essa classificação comporta a subdivisão entre omissões secundárias e primárias. Naquelas, não houve o desenvolvimento de princípios ou bases gerais de regimes jurídicos impostos pela própria Constituição.

${ }^{326}$ DJU 30/05/2003.

${ }^{327}$ DJU 20/09/96.

${ }^{328}$ DJe de 18/04/2013, relator Ministro Gilmar Mendes.

${ }^{329}$ Veja-se a descrição do caso no item 1.3.1.2.1.
} 
Se as omissões totais suscitam o problema da correta identificação do dever de legislar, as omissões parciais provocam questões mais complexas. Nelas, avulta também a questão atinente à aferição do parâmetro de insuficiência do atendimento da norma constitucional pela lei ordinária. Em alguns casos, a priori, a tarefa de descobri-lo não se revela tão difícil.

Tome-se o exemplo do parágrafo único do artigo 185, da Constituição, que demanda uma lei para garantir o tratamento especial à propriedade produtiva (primeira parte), ao mesmo tempo em que deverá fixar normas para o cumprimento dos requisitos relativos à sua função social (segunda parte). Se a lei editada não regulamentar as duas partes, deixando uma sem tratamento legislativo, então a omissão parcial terá sido evidenciada.

Nesse campo, o que torna a verificação de uma omissão menos trivial, para dizer o mínimo, é o exame da suficiência da norma quanto ao seu conteúdo. Quando se diz que o salário mínimo é suficiente? Quais os critérios que podem ser considerados bastantes para comprovar que um idoso ou um portador de deficiência física não possuem meios de prover à própria manutenção ou a de sua família?

Volte-se ao caso da Rcl. $n^{\circ}$ 4374/PE. Sabe-se que ali ficou definido que o critério objetivo escolhido pelo artigo $20, \S 3^{\circ}$ da Lei 8.742/1993 para comprovar a miserabilidade (renda familiar máxima per capita de 1/4 de salário mínimo) não é suficiente para garantir a proteção desejada pela norma constitucional correspondente. Os argumentos utilizados para isso foram as "notórias mudanças fáticas (políticas, econômicas e sociais) e jurídicas (sucessivas modificações legislativas dos patamares econômicos utilizados como critérios de concessão de outros benefícios assistenciais por parte do Estado brasileiro)". Qual o dever de legislar infringido? Considerou o Tribunal que foi o dever de adaptação da lei, pela proibição de conferir proteção insuficiente, à moda alemã, nos termos do voto do ministro relator. Observe-se que se lançou mão de subsídios típicos de discussões políticas, como estudos e reuniões com o Ministério do Desenvolvimento Nacional e com o INSS, como afirmou o ministro relator.

Superada a primeira classificação, diz-se também que as omissões inconstitucionais podem ainda ser absolutas ou relativas. 
Segundo esse critério, a doutrina costuma apontar que as omissões absolutas são as que "decorrem da violação, por inércia, de um dever autônomo de legislar", ${ }^{330}$, sem que seja relevante o desrespeito ao princípio da igualdade ${ }^{331}$. As omissões relativas, por sua vez, implicam a vulneração do princípio da igualdade. Assim, "se no primeiro caso o legislador deveria necessariamente atuar, no outro isso não ocorre. Aqui, podia o legislador manter-se inerte sem ofender a Constituição. Mas se revolveu atuar, então não cabia descumprir o princípio da isonomia"332.

É também consenso na doutrina que as omissões totais e parciais e absolutas e relativas podem combinar-se. Omissões absolutas naturalmente podem apresentar-se sob as formas total e parcial (mas as totais serão sempre absolutas) ${ }^{333}$. Em relação às omissões relativas, estas podem se manifestar também como omissões parciais. Nesse caso, haveria o dever específico de legislar, que foi cumprido com deficiência, sendo que essa mácula manifestou-se na infringência do princípio da igualdade.

Exemplo clássico é o dever que tem o legislador de conceder revisão geral anual aos servidores públicos sem distinção de índice (artigo 37, X, Constituição Federal). Ausente a lei, a omissão será absoluta e total. Se a lei não refletir os índices de inflação, por exemplo, gerará omissão parcial. Se, por outro lado, não contemplar certas categorias de servidores ou se houver a distinção de índices de revisão entre diversas categorias, entende-se que a omissão será também relativa, além de parcial. Isso porque haverá a vulneração do princípio da isonomia ${ }^{334}$.

Tradicionalmente, a jurisprudência do STF, quanto ao tratamento da questão da omissão legislativa em confronto com princípio da igualdade, em termos de remuneração de servidores, é a de negar a condição do Tribunal como legislador positivo. A súmula $n^{\circ}$ 339, resultado da jurisprudência da década de 1960 sobre o tema, é exemplo nesse sentido. No entanto, no RMS 22.307/DF ${ }^{335}$, decidiu o Tribunal que o reajuste de $28,86 \%$ concedido somente aos servidores militares, excluindo os servidores civis, portanto, feria o princípio da isonomia. Nada obstante, já fora do âmbito pecuniário, o STF, em nítida decisão de ${ }^{330}$ Cf. CLÈVE, Clemerson Merlin. A fiscalização abstrata de constitucionalidade no direito brasileiro, cit, p. 223.

${ }^{331}$ Cf. SILVA, Jorge Pereira da. Dever de legislar e protecção jurisdicional contra omissões legislativas.., cit, p. 90.

${ }^{332}$ Cf. CLÈVE, Clemerson Merlin. A fiscalização abstrata de constitucionalidade no direito brasileiro, cit, p. 223.

${ }^{333}$ Cf. RAMOS, Elival da Silva. Controle de Constitucionalidade no Brasil..., cit, p. 95; CLÈVE, Clemerson Merlin. A fiscalização abstrata de constitucionalidade no direito brasileiro, cit, p. 328.

${ }_{334}^{334}$ Cf. BERNARDES, Juliano Taveira. Controle abstrato de constitucionalidade, cit, p. 226.

${ }^{335}$ DJ de 13/06/1997, relator Ministro Marco Aurélio. 
vertente normativista, procedeu à equiparação os efeitos da união estável aos casais

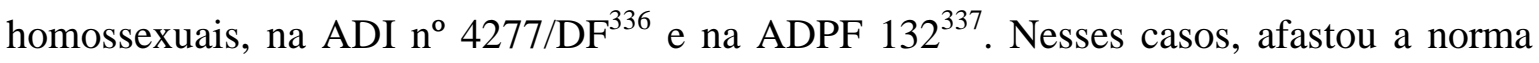
implícita excludente e, portanto, na sua visão, inconstitucional: o alijamento indevido dos casais homossexuais do conceito de família, sob sexo ou orientação sexual não pode ser fonte de discriminação.

As omissões podem ser classificadas conforme a possibilidade de serem colmatadas por outras normas existentes no bojo do próprio ordenamento jurídico. Assim, quando se evidencia o silêncio legislativo em relação a uma norma constitucional em particular, e se houver outras normas ordinárias, mesmo que sejam pré-constitucionais ou mesmo disposições regulamentares, e se estas normas puderem colmatar, ainda que de forma imperfeita, o vazio legislativo verificado, a omissão é substituível. É assim chamada porque o juiz pode utilizar uma norma por outra e, assim, mediante exercício hermenêutico, antecipar-se ao legislador. Se tal possibilidade não ocorrer, a omissão será insubstituível. Como se verá no capítulo 3, essa noção se concatena com imposições constitucionais substituíveis ou insubstituíveis. Com base nesse mesmo critério, há quem as classifique em impuras (que seriam as substituíveis) e puras (insubstituíveis) ${ }^{338}$.

Se o ordenamento jurídico contar com instrumentos processuais próprios para o preenchimento de omissões legislativas em controle concreto de constitucionalidade, as omissões superáveis são qualificadas de "em sentido estrito" 339 . Conquanto essa solução seja pensada para os casos em que já existe uma lei e esta é considerada insuficiente, hipótese mais comum na jurisdição constitucional europeia, pode-se arrolar como exemplo o caso brasileiro. Nessa categoria se inseriria, então, a jurisprudência atual do STF quanto aos mandados de injunção impetrados para possibilitar a fruição do direito de greve dos servidores públicos, previsto no artigo 37, VII, da Constituição Federal, (MIs 670/ES; 708/DF; 712/PA) ${ }^{340}$ e também para a dar efetividade ao direito à aposentadoria especial a algumas categorias de servidores públicos, constante do artigo 40, $\$ 4^{\circ}$, III, Constituição Federal (MI no 721-7/DF ${ }^{341}$ ). É que nesses casos, o Tribunal, ao apreciar demandas veiculadas por instrumento processual específico para lidar com omissões

\footnotetext{
${ }^{336}$ DJe divulgado em 13/10/2011, relator Ministro Ayres Britto.

${ }^{337}$ DJe divulgado em 13/10/2011, relator Ministro Ayres Britto

${ }^{338}$ Cf. PICARDI, Nicola. Le sentenze integrative della Corte Costituzionale, cit, pp. 46-47.

${ }^{339}$ Cf. SILVA, Jorge Pereira da. Dever de legislar e protecção jurisdicional contra omissões legislativas.., cit, p. 93.

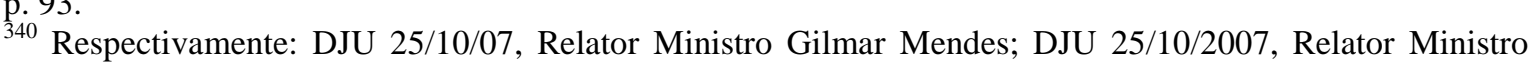
Gilmar Mendes; DJU 25/10/2007, Relator Ministro Eros Grau.

${ }^{341}$ DJU 30/08/2007, Relator Ministro Marco Aurélio.
} 
inconstitucionais, utilizou leis já existentes no ordenamento jurídico para preenchimento dos vazios normativos encontrados, mediante uso de analogia (lei $n^{\circ} 7.783 / 89$, para o direito de greve, e artigo $57, \S 1^{\circ}$, lei $n^{\circ} 8.213 / 91$, para o direito à aposentadoria especial).

Diga-se ainda que as omissões são definidas em evitáveis ou inevitáveis e são aplicadas mormente em se tratando de dar concreção aos direitos sociais. No primeiro grupo, as omissões poderiam ser muito bem colmatadas pelo legislador, porquanto estão reunidas todas as condições econômico-orçamentárias para tanto. No segundo caso, essas questões extrajurídicas ainda não se encontram superadas ${ }^{342}$.

${ }^{42}$ Tal classificação é dada por RODRIGUEZ, Jose Julio Fernandez. La inconstitucionalidad por omisión...cit, p. 121. 


\section{O DEVER DE LEGISLAR E CARACTERÍSTICAS ESPECÍFICAS DAS NORMAS CONSTITUCIONAIS}

\subsection{Introdução}

O capítulo 1 foi dedicado à liberdade do legislador. Desde o constitucionalismo oitocentista até a Segunda Guerra Mundial, praticamente, ele gozava de faculdade inquestionável (ou mesmo limitável) para definir quando e se legislar. Mesmo nas Constituições de índole programática, como as de 1934, 1937 e, sobretudo, a de 1946, falar-se em imposição de deveres ao legislador ou sancionar seu silêncio como inconstitucional eram atitudes impensadas, porquanto as normas constitucionais nãoexecutáveis eram concebidas, no limite, como dependentes da atuação legislativa, e que isso se situava no âmbito da sua exclusiva discricionariedade política. Assim, à falta da lei referida pela Constituição, viu-se que o Supremo Tribunal Federal até reconhecia a situação de omissão legislativa (não exatamente com essas palavras). No entanto, julgava-a desprovida de maiores consequências constitucionais. Não havia outra solução senão aguardar até que a lei fosse finalmente produzida.

No constitucionalismo democrático, dada a concepção de Constituição aberta, em que a atividade legislativa é de concreção da norma constitucional, e não meramente de execução de seus termos, a liberdade de conformação é ainda muito ampla. Contudo, evidencia-se um estreitamento nas relações do legislador com a Lei Fundamental. A intensidade da subordinação do primeiro à segunda ocorre em diferentes graus.

Já no capítulo 2, estudou-se o fenômeno da inconstitucionalidade por omissão, causado pelo silêncio do legislador que vulnera um dever de legislar que a Constituição lhe impõe. Nesse espaço, viu-se que a vigorosa atuação da justiça constitucional europeia, desde o início do funcionamento dos Tribunais Constitucionais, no exercício da reposição da igualdade, reforçou o caráter vinculante das normas constitucionais, sobretudo as que tratavam de direitos fundamentais.

Com base na vinculação do legislador, que se teria irradiado por toda a Constitução a partir dos direitos fundamentais, a doutrina nacional geralmente conecta uma norma preceptiva não exequível por si mesma (na classificação de Jorge Miranda, que aqui se adota) - e às vezes até normas programáticas - a um dever específico de legislar. Assim, 
como essas normas são caracterizadas pela necessidade de intervenção legislativa, poderão invariavelmente motivar uma declaração de inconstitucionalidade por omissão, se o legislador não lhes der concreção.

Tambem foram analisadas as correntes teóricas que se formaram em torno do inadimplemento do dever de legislar. Assim, a inconstitucionalidade por omissão ou resulta numa decisão judicial que censura o silêncio do legislador, isto é, a conduta omissiva, como acontece no controle abstrato, ou dá azo à produção de um resultado normativo implícito (norma implícita inconstitucional), este sim atentatório à Constituição. Neste último caso, a declaração de inconstitucionalidade, neste caso, não tem como objeto sancionar o comportamento omissivo do legislador. O que é relevante é apenas o reconhecimento da produção de uma norma implícita inconstitucional, o que habilita a Corte a afastá-la, preenchendo, mediante uma sentença de cunho aditivo, a parte faltante no ato normativo em que a lesão à Constituição foi descoberta.

Nesse terceiro capítulo, será o momento de discutir em que hipóteses se está diante de um dever específico de legislar. Sim, pois se atualmente a reserva de lei não pode significar liberdade irrestrita ao legislador, tal como no constitucionalismo liberal clássico, do mesmo modo é cientificamente duvidosa a posição segundo a qual toda e qualquer remissão do poder constituinte seja de fato uma imposição constitucional.

Essa discussão será pautada por alguns critérios extraíves de características específicas presentes nas normas constitucionais. Igualmente, serão analisados vários julgados do STF relativos à omissão inconstitucional.

Nesse intento, primeiramente serão analisados os casos em que o legislador somente atribui a competência ao ente federativo para emaná-la. Não se olvidarão, outrossim, as normas que estipulam um prazo certo para o legislador emanar a norma faltante. A seguir, a discussão se aprofundará para os casos de reserva de lei. A partir dela, serão vistas outras características presentes em certas normas constitucionais que podem inibir o reconhecimento de uma omissão inconstitucional. E aqui interessarão as questões políticas e a análise de normas programáticas e sua natureza de um compromisso para o futuro. Finalmente, serão lembradas outras hipóteses de dever de legislar que, normalmente, pressupõem a existência de uma lei.

Uma premissa a ser levada em conta, na esteira do que fez Vanice Regina Lírio do Valle, é o caráter finalístico do objeto a ser investigado: a delimitação do dever concreto 
e específico de legislar serve para também delimitar a atuação da jurisdição constitucional quanto ao controle de constitucionalidade por omissão ${ }^{343}$. Isto é, aquele dever é construído em função da possibilidade de atuação jurisdicional no controle das omissões legislativas.

\subsection{Critérios utilizáveis para aferição do dever constitucional de legislar}

\subsubsection{Normas de competência e atividade legislativa ${ }^{344}$}

A Constituição é fonte de justificação do Estado e do Direito. Se ela efetivamente os cria ou não, é uma discussão para a qual esse trabalho não enveredará. É, sem dúvida, norma normarum do ordenamento jurídico, o centro irradiador e conformador por excelência de todo o sistema de fontes jurídicas. A propósito, essa é uma das afirmações mais repetidas, com a qual se deparará quem se atreve a estudar e a escrever sobre o Direito Constitucional. Como norma primária sobre a produção jurídica, a Constituição tem as funções de (a) identificar as demais fontes do direito; (b) estabelecer critérios de validade e eficácia de cada uma dessas fontes; e (c) determinar a competência das entidades responsáveis pela emanação de normas de direito positivo ${ }^{345}$.

Quando se pensa em Constituição como inspiradora do sistema de fontes, como uma norma jurídica - ou melhor, como conjunto de normas jurídicas - pode-se incluí-la no objeto do estudo da Teoria do Direito ou mesmo da Filosofia do Direito. Nesses âmbitos, releva estudar a noção de competência, que nada mais é que o poder de produzir normas jurídicas que regularão a conduta humana. Atribuir um poder jurídico, nessa circunstância, significa conceder ao indivíduo "capacidade de produzir Direito"346.

Poderia a norma de competência ser uma fonte de dever específico de legislar?

Conforme o pensamento de Hans Kelsen, se se trata de um poder de criação do Direito, as noções de competência e autorização se confundem. Por conseguinte, “(...) não é supérfluo realçar que, quando a um indivíduo é conferida competência para uma

\footnotetext{
${ }^{343}$ Cf. VALLE, Vanice Regina Lírio do. Sindicar a omissão legislativa, cit., p. 158.

${ }^{344}$ Esclareça-se que a ideia de pesquisar o dever de legislar a partir da competência jurídica foi inspirada a partir da leitura do seguinte trabalho: GOMES, Felipe Lima; TALEIRES, Janaína Sena. A liberdade de conformação do legislador no âmbito dos direitos fundamentais, p. 8. Disponível em www.publicadireito.com.br/artigos/?cod=d3696cfb815ab692. Consultado em 20/10/2013, às 15:00h.

${ }^{345}$ Esse é o vaticínio de CANOTILHO, J. J. Gomes. Direito Constitucional e Teoria da Constituição, cit. p. 693.

${ }^{346}$ Cf. KELSEN, Hans. Teoria Pura do Direito, cit., p. 132.
} 
determinada conduta, ele não tem de ser, por tal motivo, obrigado a essa conduta". Logo, apenas uma ação positiva, e não uma omissão, pode ser objeto de atribuição de competência ${ }^{347}$. Por outro lado, é o resultado desse poder (a ordem ou o comando) é que pode ser uma ação ou uma omissão, isto é, um dever jurídico, o qual, por sua vez, está essencialmente ligado a uma sanção ${ }^{348}$.

Por conseguinte, é no âmbito da autorização que o autor supracitado coloca a atividade legislativa: a Constituição autoriza o legislador a produzir normas jurídicas de caráter geral. Mas, se ele não faz uso dessa autorização, não comete nenhuma infringência ao Direito ${ }^{349}$.

Como se sabe, a Constituição brasileira de 1988 atribui competências aos entes que compõem a federação e também aos Poderes de cada um deles. Transpondo as noções kelsenianas de competência do âmbito da Teoria Geral do Direito para o do Direito Constitucional, tem-se que as competências, sejam as legislativas, comuns ou exclusivas, sejam as privativas de cada Poder, geralmente ostentam natureza de uma faculdade. Deste modo, se à União compete legislar sobre desapropriação (art. 22, II) ou populações indígenas (XIV), mas se ela não o faz, as simples normas de atribuição de competência não podem motivar uma declaração de inconstitucionalidade por omissão. Assim, delas não seriam extraíveis deveres específicos de legislar.

Nos MIs $\mathrm{n}^{\mathrm{o}} 765 / \mathrm{DF}^{350}$ e 766/DF ${ }^{351}$, o STF corroborou o entendimento acima, ao reconhecer que as normas de competência situam-se no âmbito da discricionariedade do Poder Público. Esses writs foram impetrados por empresas que exerciam a atividade de bingo, sob o fundamento de inércia legislativa para a regulamentação desse jogo de azar. $\mathrm{O}$ Tribunal não conheceu deles, sob o fundamento de que a função do mandado de injunção era proteger um direito subjetivo do impetrante, na esteira do que havia muito entendia o Ministro Celso de Mello, ${ }^{352}$ e que esse direito só existiria "naquelas estritas hipóteses em que o desempenho da função instauradora da ordem normativa refletir, por efeito de determinação constitucional, uma obrigação jurídica indeclinável do Poder Público”, isto é,

\footnotetext{
347 Afirma o autor que "podemos, portanto, ser juridicamente obrigados a fazer ou a omitir algo; mas apenas nos pode ser conferido poder ou competência para fazer algo" (Teoria Pura do Direito, cit., p. 132).

${ }^{348}$ Segundo Hans Kelsen, "ser a conduta de um indivíduo prescrita por uma norma objetivamente válida é equivalente a ser esse indivíduo obrigado a essa conduta" (Cf. Teoria Pura do Direito, cit. pp. 16-17 e 130).

${ }^{349}$ KELSEN, Hans. Teoria geral das normas. Porto Alegre: Sérgio Antônio Fabris Editor, 1986, p. 130; KELSEN, Hans. Teoria geral do direito e do Estado, cit., p. 376.

${ }^{350}$ Decisão monocrática da presidência de DJ 02/08/2007.

${ }^{351}$ Decisão monocrática da presidência publicada no DJ de 03/08/2007.

${ }^{352}$ Ver item 2.4.1.
} 
"é essencial que se estabeleça necessária correlação entre a imposição constitucional de legislar, de um lado, e o direito público subjetivo à legislação, de outro, de tal forma que, ausente a obrigação jurídica de emanar provimentos legislativos, não se torna possível imputar comportamento moroso ao Estado". Justificou-se ademais que os impetrantes não apontaram o artigo da Constituição que teria sido contrariado pelo silêncio do legislador.

Essas decisões foram confirmadas nos julgamentos dos recursos de Agravo Regimental $^{353}$ e 354 , interpostos na sequência daquelas decisões. Nos acórdãos, o Tribunal julgou que não havia determinação constitucional para que o legislador regulamentasse a atividade de bingos, e que tal regulamentação situava-se no âmbito discricionário da União, não existindo, pois, direito a essa medida.

Conquanto os julgamentos acima relatados não tivessem feito expressa menção ao art. 22, XX, da Constituição Federal, que diz competir à União legislar sobre consórcios e sorteios, a conclusão a que chegou o Tribunal àquele preceito se conexiona, pois de todo modo fez alusão a uma norma de competência.

O mesmo parece ocorrer em relação às normas de competência privativa dos poderes que compõem os entes federativos. A seguinte amostra é esclarecedora desse ponto.

As Constituições brasileiras, desde 1934 - à exceção da de 1937, que previa que o Poder Legislativo era composto pela Câmara dos Deputados e pelo Conselho Federal, e este, por sua vez, tinha atribuições reduzidas - sempre atribuíram ao Senado a competência de suspender a execução, no todo ou em parte, de lei declarada inconstitucional pelo Supremo Tribunal Federal, por decisão definitiva ${ }^{355}$. Na Constituição vigente, este preceito está estampado no art. 52, X. Sempre houve discussão na doutrina sobre a obrigatoriedade ou não de o Senado Federal proceder à suspensão supracitada: aquela norma de competência teria natureza de um dever?

Os argumentos utilizados pelos que defendiam a tese da obrigação do Senado em suspender a lei era o de que o objetivo da Constituição, ao prever tal competência, era o de dar publicidade às decisões do STF a todos os cidadãos ${ }^{356}$. Ademais, isso seria evidência de uma atividade constitucionalmente vinculada, desde que observados os

\footnotetext{
${ }^{353}$ DJe divulgado em 31/01/2012, relator ministro Dias Toffoli, para o MI 765

${ }^{354}$ DJe divulgado em 12/11/2009, relator Ministro Joaquim Barbosa, para o MI 766.

355 Constituição de 1934, art. 91, IV; Constituição de 1946, art. 64; Constituição de 1967, art. 45, IV; Constituição de 1969, art. 42, VII.

${ }^{356}$ Cf. BITTENCOURT, Lucio. O controle jurisdicional da constitucionalidade das leis, cit., p. 145.
} 
requisitos formais para isso, como o quórum no STF e que a omissão em relação à suspensão poderia ocasionar um conflito entre poderes ${ }^{357}$. Logo, ainda que o Senado Federal não fosse um "cartório de registro dos atos do Supremo Tribunal Federal", conforme lição de Pontes de Miranda, deveria obrigatoriamente atender à comunicação do STF, considerando que, nesse caso, o ato do Senado, de natureza legislativa, funcionaria como "executor de uma decisão do Supremo Tribunal Federal", que era, afinal, guardião da Constituição ${ }^{358}$.

Mas, o certo é que o STF de modo geral entendia que, na decisão do Senado de suspender ou não a lei, sobressaía a qualidade de poder político, circunscrito à conveniencia e oportunidade. São várias as manifestações da Corte nesse sentido, cujos maiores expoentes nesse tema foram os Ministros Aliomar Baleeiro e Victor Nunes Leal, no emblemático MS 16.512/DF ${ }^{359}$.

Nesse julgado, aquele Ministro ponderou que o Senado tem o "direito" de decidir pela suspensão ou não, e tomar uma atitude somente depois de pacificada a questão no próprio Supremo Tribunal Federal, e não mediante comunicação em um caso singular. Isso porque poderia ser que a resolução votada no Senado com base numa única decisão, pudesse posteriormente tornar-se inócua, pela mudança de posição do Supremo. Poderia ser, inclusive, que o próprio Senado procedesse a uma reforma na Constituição, de modo a preservar a lei. Poderia, finalmente, não fazer nada, porque não havia qualquer sanção à sua resistência. Por essa razão, se se recusasse dar maior extensão aos efeitos da decisão judicial, não haveria qualquer abalo nas relações entre os poderes ${ }^{360}$, até mesmo porque o Senado nem poderia revogar o ato julgado inconstitucional pelo Supremo ou tampouco alterar os fundamentos da decisão ${ }^{361}$.

O Ministro Victor Nunes Leal, por sua vez, percorreu a mesma seara ao dizer que, no ato de sopesamento sobre suspender ou não a lei declarada inconstitucional, o Senado haveria de levar em conta a oscilação da jurisprudência do Tribunal.

\footnotetext{
357 É o caso, por exemplo, do Ministro Thompson Flores, em seu voto na Representação no 933 , DJ de 26/12/1975.

${ }^{358}$ Voto do Ministro Pedro Chaves, no adiante mencionado MS 16.512/DF.

${ }^{359}$ DJ de 31/08/1966, relatoria do Ministro Oswaldo Trigueiro.

${ }^{360}$ Cf. MENDES, Gilmar Ferreira. Direitos fundamentais e controle de constitucionalidade, cit., p. 752.

361 Cf. MARINHO, Josaphat. O art. 64 da Constituição e o papel do Senado. Revista de informação legislativa. $\quad$ v. $\quad 1, \quad$ n. $\quad 2, \quad$ p. $\quad 5-12, \quad$ jun. 1964 Disponível http://www2.senado.leg.br/bdsf/bitstream/handle/id/180651/000347388.pdf?sequence=1. Acesso em 29/12/2014, às 17:30h.
} 
No mesmo sentido seguiram as decisões no MS 16.519/DF ${ }^{362}$, notadamente o voto do relator, o Ministro Luiz Gallotti, e também a um pouco menos antiga, na Representação $\mathrm{n}^{\mathrm{o}}$ 1.012/SP $\mathrm{SP}^{363}$, de relatoria do Ministro Moreira Alves, que diz que o Senado poderá suspender a lei "se houver por bem (decisão de conveniência política)"364

Essa discussão, atualmente, pode até padecer de certo anacronismo, pela substituição de uma outra: a que versa sobre a mutação constitucional deste mesmo preceito, em virtude dos efeitos das sentenças exaradas pelo STF em sede de controle incidental de constitucionalidade, o que seria indicativo da obsolescência desse artigo ${ }^{365}$. Nada obstante, tem a importância de indicar que, no mais das vezes, o estabelecimento de uma competência não implica a imposição de um dever concreto e específico.

Outro exemplo de atribuição de competência de caráter autorizativo é o próprio direito de veto, dado ao Presidente da República, pelos arts. 66, $\S 1^{\circ}$ e $84, \mathrm{~V}$, da Constituição de 1988. Se para o veto jurídico (que é aquele fundamentado em uma inconstitucionalidade) seria algo teratológico pensar numa obrigação do Chefe do Executivo em vetar determinado projeto de lei, imagine-se para o veto fundado em interesse público. A propósito, tanto não é um dever vetar que, pelo disposto no $\S 3^{\circ}$ daquele preceptivo, se passados in albis o prazo de quinze dias contados da data do recebimento do projeto de lei, o silêncio do Presidente importará sanção.

Nada obstante, pode acontecer que a atribuição de uma competência refuja aos limites de uma autorização, convertendo-se em verdadeira obrigação: "uma ação para a qual a ordem jurídica atribui competência a um indivíduo pode, ao mesmo tempo, ser prescrita ou ordenada, isto é, pode ser tornada conteúdo de seu dever" ${ }^{366}$. Pensando nestes termos, é teoricamente possível caracterizar a autorização dada ao legislador também como uma função impositiva, isto é, como um dever jurídico, ainda que, reitere-se, o próprio autor tenha sempre desconfiado dessa hipótese ${ }^{367}$.

\footnotetext{
${ }^{362}$ DJ de 09/11/1966.

${ }^{363}$ DJ de $05 / 11 / 1979$.

${ }^{364}$ Cf. também BROSSARD, Paulo. O Senado e as leis inconstitucionais. Revista de informação legislativa. Disponível em http://www2.senado.leg.br/bdsf/bitstream/handle/id/181304/000393215.pdf?sequence=3. Consultado em 27/12/2014, às 21:00h.

${ }^{365}$ Cf. MENDES, Gilmar Ferreira. Direitos Fundamentais e controle de constitucionalidade, cit, p. 753 ; ALMEIDA, Fernando Dias Menezes de. Considerações sobre a função do Senado Federal de suspender execução de lei declarada inconstitucional pelo Supremo Tribunal. Revista de informação legislativa. v. 44, n. 174, p. 15-24, abr./jun. 2007, 04/2007. Disponível em http://www2.senado.leg.br/bdsf/bitstream/handle/id/140960/R174-18.pdf?sequence=2. Acesso em 27/12/1014, às 22:00h.

${ }^{366}$ Cf. KELSEN, Hans. Teoria Pura do Direito, cit., p. 132.

${ }^{367}$ Ver item 2.1.2.
} 
Bem de ver, então, que o princípio da competência demarca, de modo positivo, a legitimidade de entes federativos e outras entidades para a regulamentação - ou, pelo menos para iniciar o processo de regulamentação, pela iniciativa reservada de lei - de determinadas matérias (além dos artigos supracitados, pense-se, por exemplo, no art. 93, que dá ao STF a iniciativa de lei sobre o Estatuto da Magistratura).

Sob esse fundamento, a propósito, a distribuição de competências pela Constituição, que é a autoridade exclusiva para essa tarefa, resulta, em muitos casos, à restrição da atividade legislativa. Com efeito, fora das hipóteses expressamente por ela autorizadas ( $v . g$. , arts. 22, parágrafo único e 24 , caput e $\S \S 1^{\circ}$ a $4^{\circ}$ ), o legislador de um ente federativo não poderá legislar sobre matéria para a qual não tem competência, sob pena de desvirtuação da própria Federação. Do mesmo modo, não se olvide que o legislador não pode dispor sobre matérias que a própria Constituição preferiu detalhar, como o processo legislativo e certas garantias fundamentais ${ }^{368}$, dentro do que se convencionou chamar de reserva absoluta de Constituição ${ }^{369}$. Trata-se, portanto, de verdadeiros deveres de não legislar.

Assim é que normas de competências isoladamente consideradas não indicam um dever específico de legislar, com o que não é possível dizer que elas animam uma declaração de inconstitucionalidade por omissão ${ }^{370}$. Nessa perpectiva, a atribuição de competência legislativa revela, no máximo, um dever geral que, como se viu no Capítulo 2, nao é o bastante para qualificar o silêncio legislativo como inconstitucional. Os deveres gerais de legislar situam-se, de consequência, ainda no campo político-constitucional, enquanto que os deveres específicos pertenceriam, repise-se, ao campo jurídicoconstitucional $^{371}$.

Logo, para que uma omissão legislativa seja constitucionalmente relevante, outros elementos devem ser agregados à competência. Esses elementos, quando evidenciados, funcionam, assim, como parâmetros para a definição de um dever específico imposto ao legislador. Identificá-los e analisa-los é o que será feito a partir desse ponto.

\footnotetext{
${ }^{368}$ Cf. RAMOS, Elival da Silva. Ativismo judicial. Parâmetros dogmáticos, cit., pp. 180-181.

${ }^{369}$ VAZ, Manuel Afonso. Lei e reserva de lei..., cit., p. 297.

${ }^{370}$ GOMES, Felipe Lima; TALEIRES, Janaína Sena. A liberdade de conformação do legislador no âmbito dos direitos fundamentais, cit, p. 8.

${ }^{371}$ SILVA, Jorge Pereira da. Dever de legislar e protecção jurisdicional contra omissões legislativa..., cit. pp. 22-23.
} 


\subsubsection{O critério do prazo certo fixado pela norma}

Quando se analisou o momento em que ocorre uma omissão inconstitucional, o que foi feito no item 2.4.2.1, asseverou-se que um dos poucos pontos em que a doutrina parece ser concorde em tema de inconstitucionalidade por omissão é quando a própria norma constitucional fixa prazo para a produção da $\mathrm{lei}^{372}$. A par de funcionar como óbvio delimitador temporal da ocorrência do fenômeno, serve, de igual modo, como o critério mais preciso para a delimitação de um dever concreto, e que menos polêmica desperta: a fixação de prazo é elemento deveras significativo na identificação de uma omissão inconstitucional ${ }^{373}$ porque nela avulta o caráter de obrigação, de dever a ser cumprido pelo legislador. Seguramente, é também o menos abrangente, pois, como se sabe, as normas que estabelecem um termo ad quem para a produção legislativa são em diminuto número na Constituição.

O prazo, nada obstante, nem sempre será indicação definitiva de um dever específico. Nesse campo, um caso bastante peculiar, e que é digno de nota, envolve os projetos de leis orçamentárias. Em relação ao orçamento público, o art. 166, § $6^{\circ}$ diz que “os projetos de lei do plano plurianual, das diretrizes orçamentárias e do orçamento anual serão enviados pelo Presidente da República ao Congresso Nacional, nos termos da lei complementar a que se refere o art. $165, \S 9^{\circ}$ ”. Como nem a lei $\mathrm{n}^{\circ} 4.320 / 64$, nem a lei complementar $\mathrm{n}^{\mathrm{o}}$ 101/2000 estabelecem prazos, continua aplicável o art. 35, do Ato das Disposições Constitucionais Transitórias, que determina que enquanto não editada a lei complementar a que o art. $165, \S 9^{\circ}$ menciona, os prazos a serem obedecidos serão os seguintes: (a) para o projeto de plano plurianual para a vigência até o final do primeiro exercício financeiro do mandato presidencial subsequente, quatro meses antes do encerramento do primeiro exercício financeiro e devolvido para sanção até o encerramento da sessão legislativa; (b) para o projeto de lei de diretrizes orçamentárias, até oito meses e meio antes do encerramento do exercício financeiro e devolvido para sanção até o encerramento do primeiro período da sessão legislativa; e (c) para o projeto de lei orçamentária da União: até quatro meses antes do encerramento do exercício financeiro e devolvido para sanção até o encerramento da sessão legislativa.

\footnotetext{
${ }^{372}$ Cf. ainda: LEAL, Roger Stiefelmann. Direitos sociais e a vulgarização da noção de direitos fundamentais. Programa de Pós-Graduação em Direito - UFRGS, p. 3. Disponível em http://www.ufrgs.br/ppgd/doutrina/leal2.htm. Acesso em 13/08/2014, às 17:00h.

${ }^{373}$ VALLE, Vanice Regina Lírio. Sindicar a omissão inconstitucional: real desafio à harmonia entre os poderes. Belo Horizonte : Editora Forum, 2007, p. 164.
} 
Se o Presidente da República não envia os projetos nos prazos assinalados ele pode ser considerado moroso? Poderia também o Poder Legislativo praticar omissão inconstitucional pela não observância dos prazos assinalados acima? No julgamento da ADI 4.048-MC ${ }^{374}$ o Tribunal assentou a possibilidade "de submissão das normas orçamentárias ao controle abstrato de constitucionalidade”, quando houver um tema ou controvérsia constitucional suscitada em abstrato. A partir disso, a priori e numa análise assaz perfunctória da questão, a não obediência àqueles prazos poderia fundamentar o controle de constitucionalidade por omissão. Mas, em termos pragmáticos, a possibilidade de ocorrência de uma inconstitucionalidade por omissão não se evidencia.

No ponto, impende ter em mira que o art. 32 , da lei ${ }^{\circ} 4.320 / 64$, determina que “se não receber a proposta orçamentária no prazo fixado nas Constituições ou nas Leis Orgânicas dos Municípios, o Poder Legislativo considerará como proposta a Lei de Orçamento vigente". Essa solução, ainda que legal (e não constitucional) para o problema, ao que parece, e mesmo que provisoriamente, resolve a questão do incumprimento do prazo pelo Chefe do Executivo.

Em relação ao Poder Legislativo, há a determinação constitucional para que o Parlamento restitua o projeto de lei orçamentária anual até o encerramento da sessão legislativa. Mas o fato é que, enquanto não o fizer, pelo menos em tese, não haverá rececesso parlamentar ${ }^{375}$, de modo que, mesmo que o prazo não seja cumprido, há condições de preenchimento de eventual omissão.

Ademais, considerando que a lei complementar a que faz menção o art. 165, $\S 9^{\circ}$ da Constituição não veio a lume, não há regra sobre o transcurso de prazo em branco pelo Legislativo sem a deliberação da lei orçamentária anual, por exemplo. Na prática, portanto, "isto significa que é possível não ter um orçamento aprovado"376 no novo exercício financeiro.

Um problema que se liga à questão orçamentária, mesmo refugindo ao tema dos prazos, diz respeito ao encaminhamento de um projeto de lei orçamentária incompleto. Isso motiva a declaração de inconstitucionalidade por omissão parcial? Essa questão

\footnotetext{
${ }^{374}$ DJe de 22-8-2008, Relator Ministro Gilmar Mendes.

375 Cf. RIANI, Frederico Augusto D’Ávila. A vinculação do Chefe do Executivo à lei orçamentária no cumprimento das determinações constitucionais. Tese de doutorado, PUC/SP, 2008, p. 165.

${ }^{376} \mathrm{Cf}$. voto do Desembargador Jessé Torres, relator da Representação de Inconstitucionalidade $\mathrm{n}^{\circ} 0046567-$ 70.2012.8.19.0000, do Tribunal de Justiça do Rio de Janeiro. DJ de 02/07/2013.
} 
chegou a ser posta na ADI $n^{\circ} 5160 / \mathrm{DF}^{377}$, em que a Associação Nacional dos Defensores Públicos insurgiu-se contra os arts. 15 e 21 da Lei de Diretrizes Orçamentária do Acre n. 2.880/2014, pela falta de inclusão de orçamento da Defensoria Pública daquele Estado. Conforme dispõe o art. 134, $\$ 2^{\circ}$, da Constituição Federal, alterado pela Emenda Constitucional $n^{\circ} 45 / 2004$, a Defensoria tem autonomia para formular a própria proposta orçamentária. A própria Advocacia-Geral da União emitiu parecer favorável à declaração de inconstitucionalidade. A ação, no entanto, foi extinta sem o julgamento do mérito por perda do objeto, dada a superveniente aprovação da lei orçamentária anual contendo o orçamento do órgão. Pensando em termos estritamente teóricos, a hipótese de declaração de inconstitucionalidade por omissão nesse caso não parece descartada.

\subsubsection{A reserva de lei imperativa e a reserva de lei dispositiva como parâmetros para a delimitação do dever específico de legislar}

Pelo que se pôde compreender do modo como doutrina e jurisprudência brasileiras enxergam a omissão inconstitucional, exposto no capítulo 2 e relembrado rapidamente na introdução do presente capítulo, o conceito do dever específico de legislar corresponde às normas preceptivas não exequíveis por si mesmas, ou, conforme a classificação geralmente utilizada pela doutrina nacional, às normas de eficácia limitada.

Não é segredo que aquele tipo de normas desde a publicação da Constituição é eficaz, mas com alcance diminuto quanto à sua exequibilidade, pela falta de densidade conteudística. Daí por que remeterem precipuamente ao legislador a tarefa de completarem-nas.

Da mesma forma, já está esclarecido que o instrumento desta remissão é a reserva de $1 \mathrm{ei}^{378}$. A propósito, e volte-se ao capítulo 1 , houve a oportunidade de demonstrar que a reserva de lei sempre esteve presente nas Constituições. No constitucionalismo liberal, em particular, a lei em sentido estrito figurava como espécie proeminente no

\footnotetext{
${ }^{377}$ DJe divulgado em 17/12/2014, Relatora Ministra Cármen Lúcia.

${ }^{378}$ É evidente que a reserva de lei, ao cumprir esse objetivo, interfere na amplitude da eficácia do preceito constitucional, pois isso implica também o estabelecimento de limites. E isso é particularmente importante quando o assunto é relativo a direitos fundamentais. Esse problema, no entanto, não será tratado neste trabalho. O foco do estudo, reitere-se, é o de estabelecer uma delimitação do dever específico de legislar a partir da reserva de lei. Para uma análise do problema apontado conferir: HÄBERLE, Peter. La garantia del contenido esencial de los derechos fundamentales. Madri : Dykinson, 2003, especialmente no Capítulo IV.
} 
sistema de fontes jurídicas, dado que só por esse diplola normativo é que se poderia intervir na esfera de liberdade dos indivíduos ${ }^{379}$.

Na Constituição aberta, a reserva de lei ainda é utilizada em larga escala e sob diferentes aspectos.

Com efeito, ora detalha com maior precisão o conteúdo da futura lei, ora dá a oportunidade ao legislador de tão-somente fixar balizas dentro das quais, por exemplo, a Administração poderá, mediante ato regulamentar próprio, ter maior liberdade de definir o conteúdo de sua atuação. Em outros termos: nalguns casos, diz que somente por lei deverá ser veiculado determinado conteúdo constitucional; noutros, permite que este seja tratado com seus pormenores por outras fontes de produção jurídica ${ }^{380}$.

Na verdade, como bem diz Alessandro Pizzorusso, o sistema de fontes jurídicas permite que se conclua que o objeto da regulação legislativa não fique dependente apenas de regras gerais de competências, mas sim de acordo o princípio de "preferência" da fonte. Em virtude desse princípio, a matéria regulada pela fonte de grau hierárquico superior não pode ser mais regulada pela de grau inferior, a não ser que sirva esta como mera norma de intrepretação ou "execução" da matéria já disciplinada ${ }^{381}$. O que se extrai dessa lição é que certamente a norma de grau inferior não pode inovar a de grau superior, sob pena de subversão do próprio sistema, pensado em termos de hierarquias de fontes.

No entanto, a norma de grau superior pode prever que a matéria fique "reservada" à norma inferior que dela se origina, identificando, portanto, qual a norma inferior que poderia dela tratar.

Diante disso, a doutrina - mormente a estrangeira, porquanto o assunto quase não despertou o interesse da nacional ${ }^{382}$ - costuma classificar a reserva legal formal e material, absoluta e relativa.

\footnotetext{
${ }^{379}$ Cf. MORTATI, Costantino. Istituzioni di Diritto Pubblico. Pádua : Cedam, 1975, p. 341.

${ }^{380}$ Cf. XAVIER, Alberto Pinheiro. Conceito e natureza do acto tributário. Coimbra : Livraria Almedina, 1972 , pp. 285 e ss.

${ }^{381}$ Cf. PIZZORUSSO, Alessandro. Lecciones de Derecho Constitucional. Vol II. Madri : centro de estudios constitucionales, 1984, p. 159.

${ }^{382}$ Mas ainda assim evidencia-se reflexo na jurisprudência doméstica: no STF: ADI no 2.0175MC/RJ: “o tema concernente à disciplina jurídica da remuneração funcional submete-se ao postulado constitucional da reserva absoluta de lei, vedando-se, em conseqüência, a intervenção de outros atos estatais revestidos de menor positividade jurídica, emanados de fontes normativas que se revelem estranhas, quanto à sua origem institucional, ao âmbito de atuação do Poder Legislativo, notadamente quando se tratar de imposições restritivas ou de fixação de limitações quantitativas ao estipêndio devido aos agentes públicos em geral. - O princípio constitucional da reserva de lei formal traduz limitação ao exercício das atividades administrativas e jurisdicionais do Estado. A reserva de lei - analisada sob tal perspectiva - constitui postulado revestido de
} 
A reserva de lei formal diz com a dependência da regulamentação de determinada matéria contida em preceito constitucional por lei em sentido estrito: confunde-se, pois, com a reserva do parlamento ${ }^{383}$. O exemplo mais notório em termos de reserva formal se dá no campo do Direito Tributário, que exige lei em sentido estrito para a instituição e exigência de tributos (art. 150, I).

Material é o tipo de reserva em que a conduta que a Constituição demandada (sobretudo à Administração) é autorizada, por qualquer norma geral e abstrata, a ser produzida por autoridade de grau inferior, isto é, é a que permite que outros atos com força de lei possam também tratar de matérias reguladas pelas normas constitucionais, dentro de um espaço fixado pela própria lei ordinária. É em relação às reservas de lei formal e material que ocorreram os debates e dissensões sobre o que se entende por lei em sentido formal e lei em sentido material, discussão esta que não é proveitosa a este estudo ${ }^{384}$.

Sobre a intensidade de determinação fornecida pela Constituição à lei, ideia que se liga à própria intensidade do vínculo que grava o legislador ${ }^{385}$ - esta sim, particularmente interessante para este trabalho, como se verá abaixo - ou a reserva é relativa ou absoluta.

função excludente, de caráter negativo, pois veda, nas matérias a ela sujeitas, quaisquer intervenções normativas, a título primário, de órgãos estatais não-legislativos" (DJU de 27/06/2003); ADI $n^{\circ}$ 2.321MC/DF: "o Tribunal Superior Eleitoral, longe de dispor sobre tema resguardado pelo princípio constitucional da reserva absoluta de lei em sentido formal, limitou-se a proceder, em sede administrativa, a uma simples recomposição estipendiária, que não se identifica com aumento de remuneração, que não veicula o deferimento de vantagem pecuniária indevida nem traduz, ainda, outorga, em caráter inovador, de qualquer das situações financeiras de vantagem a que se refere o art. $169, \S 1^{\circ}$, da Constituição" (DJU de 10/06/2005); No Tribunal Regional Federal da 1ª Região: AC 2007.33.00.008420-8/BA: “Administrativo. Constitucional. Improbidade administrativa. Estagiárias da Caixa Econômica Federal. Inaplicabilidade da lei. Princípio da reserva legal absoluta. Definição legal de quem é reputado agente público" (e-DJF1 de 30/01/2009, p. 28); AC 2000.34.00.007124-3/DF: “A sistemática de remuneração dos servidores públicos está sujeita ao princípio da reserva legal absoluta (art. 37, X, da CF/88). Em face disso, o princípio da divisão de poderes impede a extensão do ato legislativo invocado pelos autores à situação subjetiva nele não prevista, tendo em vista que é privativa do Presidente da República (art. 61, § $1^{\circ}$, II, a, da CF/88) a iniciativa para leis que disponham sobre qualquer alteração nos vencimentos dos servidores" (e-DJF1, de 26/02/2008, p. 39).

${ }^{383}$ Cf. CANOTILHO, J. J. Gomes. Direito Constitucional e Teoria da Constituição, cit., p. 726.

${ }^{384}$ Sobre o assunto, conferir: STARCK, Christian. El concepto de lei en la constitución alemana. Madri : Centro de estudos constitucionales, 1979, pp. 47 e ss. e 246 e ss.; VAZ, Manuel Afonso. Lei e reserva da lei..., cit., p. 388 e ss.; DIEZ-PICAZO, Luis María. Concepto de ley y tipos de leyes.¿Existe una noción unitaria de ley en la Constitución española? Revista Española de Derecho Constitucional, ano 8, n. 24, set/dez 1988, especificamente itens 2 e 3 , pp. 55 e ss. Disponível em www.bibliotecadigital.inap.es/Datos/Publicaniones_Periodicas/REDC/24/REDC_24_047.pdf. Acesso em 11/12/2014, às 16:00h; LLORENTE, Francisco Rubio. Rango de ley, fuerza de ley, valor de ley (sobre el problema del concepto de ley en la Constitución. Revista de Administración Pública, nº 100-102, jan/dez 1983. Disponível em http://www.cepc.gob.es/eu/argitalpenak/ aldizkariak/aldizkarielektronikoak?IDR=1\&IDN=100\&IDA=23351. Acesso em 11/12/2014, às 18:00h.

${ }^{385}$ Cf. MORTATI, Costantino. Istituzioni di Diritto Pubblico, cit., p. 343. 
A reserva de lei relativa é aquela que consente que a disciplina normativa seja dada por fonte inferior à lei, desde que esta determine as diretivas dentro das quais as normas inferiores deverão limitar-se.

Será, por outro lado, absoluta quando a própria lei já fornecer o critério decisório (isto é, o próprio conteúdo) a ser empregado no caso concreto, de modo que o órgão incumbido de aplicá-la não terá liberdade de valoração. O que a reserva de lei pode deixar às fontes subordinadas é tão-somente a emanação de atos que visam dar maiores detalhes sobre a execução da lei ${ }^{386}$.

A norma constitucional que porta consigo uma reserva legal absoluta, na concepção de Alberto Xavier, representa "um duplo ditame", tanto para o legislador quanto para o órgão de aplicação: tanto consubstancia para o primeiro uma obrigação de formular os comandos legislativos, sob pena de inconstitucionalidade, quanto exclui, para o segundo, qualquer tipo de subjetivismo quando da aplicação da $\operatorname{lei}^{387}$.

Como referido acima, o critério da intensidade do vínculo do legislador na classificação da reserva de lei é particularmente importante a esse trabalho. Mas quem o utiliza explica pouco sobre pelo que se deve entender essa intensidade de vinculação. Se for seguida a linha definida por Costantino Mortati, ele dirá que a intensidade é da obrigação a cargo do legislador: na reserva absoluta de lei, este tem a obrigação de definir toda a disciplina normativa que Administraçao terá que seguir, e não só balizas ou limites, como na reserva de lei relativa. Disso se depreende que o constituinte, para algumas matérias, reforçou o dever do legislador, e, em outras, nem tanto. Essa orientação é seguida na doutrina brasileira por José Afonso da Silva ${ }^{388}$. Este autor, contudo, também não se preocupa desenvolver o significado desse parâmetro. Limita-se a tomá-lo do estudioso italiano e, assim, efetuar a separação das reservas de lei conforme definidas nas normas da Constituição brasileira.

Acredita-se que esse modelo de classificação pouco tem a ver realmente com a intensidade do vínculo imposto ao legislador pela Carta Magna (vínculo mais forte ou mais fraco, mais estreito ou mais permissivo). Talvez fosse melhor separar as reservas absolutas das relativas em função da extensão da tarefa do legislador (a lei deve ser mais detalhada

\footnotetext{
${ }^{386}$ Cf. MORTATI, Costantino. Istituzioni di Diritto Pubblico, cit., p. 343.

${ }^{387}$ Cf. XAVIER, Alberto Pinheiro. Conceito e natureza do acto tributário, cit. pp. 291 e 292.

${ }^{388}$ Cf. SILVA, José Afonso. Curso de direito constitucional positivo. 36 a ed. São Paulo : Malheiros Editores, 2013, pp. 426-427.
} 
ou menos detalhada), pois, ao que parece, tanto em um caso, como em outro, essa intensidade parece ser a mesma. Mas não é essa a discussão que interessa ser abordada, mas, sim, o ponto de partida das classificações supracitadas.

Com efeito, é a partir dele que se pode avançar para a averiguação de um dever específico de legislar e, em última análise, para a separação entre omissões legislativas irrelevantes do ponto de vista constitucional e as omissões que implicam uma lesão à Lei Maior, considerando ainda as características da Constituição aberta, delineadas no capítulo inicial deste trabalho.

Nesse campo, a aludida intensidade da vinculação do legislador à vontade do constituinte será adequada a revelar outras concepções de reservas de lei diretamente ligadas à noção de um dever de legislar: a reserva de lei imperativa e a reserva de lei dispositiva. Segundo Ignacio Villaverde Menéndez, essa novidadeira forma de classificar as reservas de lei conecta-se - ainda que acredite que isso não tenha sido a sua intenção final - com as imposições substituíveis e as imposições insubstituíveis pensadas pelo constitucionalista alemão Christian Pestalozza ${ }^{389}$.

Mesmo em tom severamente crítico, o autor espanhol explica que dispositiva seria a reserva de lei que tão-somente atribui a competência do tratamento de uma matéria constitucional ao legislador. Tratar-se-ia de conteúdo eminentemente negativo: "nenhum outro sujeito do ordenamento jurídico pode regular essa matéria reservada e é irrenunciável a postestade legislativa nessa matéria" ${ }^{, 390}$. É no âmbito da reserva de lei dispositiva que se situa a oportunidade do legislador de decidir quando e como legislar.

A reserva de lei imperativa, por outro lado, é aquela que vai além da mera estipulação de uma competência: é que a impõe um dever, uma obrigação inescusável de legislar sobre a matéria reservada. É imperativa porque a obrigação não consiste tãosomente na tarefa de estabelecer por ele mesmo a regulamentação de uma matéria reservada, pela remissão "em branco" a outras normas inferiores do sistema de fontes, como acontece na reserva de lei relativa. A imperatividade da reserva de lei determina que o legislador tome efetivamente a decisão de legislar ${ }^{391}$.

\footnotetext{
${ }^{389}$ Cf. MENÉNDEZ, Ignacio Villaverde. La inconstitucionalidad por omisión, cit., p. 99.

390 Cf. MENÉNDEZ, Ignacio Villaverde. La inconstitucionalidad por omisión, cit., p. 99. Do original: "ningún otro sujeto del ordenamiento jurídico puede regular esa materia reservada y es irrenunciable la potestad legislativa en esa materia".

${ }^{391}$ Cf. MENÉNDEZ, Ignacio Villaverde. La inconstitucionalidad por omisión, cit., p. 100.
} 
Advirta-se que essa é uma leitura exagerada de Christian Pestalozza ${ }^{392}$. Em verdade, o que sustenta esse jurista alemão é que nem todo mandamento constitucional é passível de fundamentar uma inconstitucionalidade por omissão. Assim, ele os distingue entre mandamentos constitucionais substituíveis (vertretbaren) e mandamentos constitucionais insubstituíveis (unvertretbaren Aufträgen), ou, numa linguagem mais familiar à doutrina brasileira e que já foi citada neste trabalho, imposições constitucionais substituíveis e imposições constitucionais não substituíveis.

Se a imposição for substituível, então o Tribunal Constitucional não deve declarar a inconstitucionalidade por omissão, mas sim assinalar aos tribunais inferiores que eles "satisfaçam" eles mesmos (por meio do processo de Konkretisierung) a ordem de legislar. Em outras palavras: mesmo sem a interpositio legislatoris, se a norma constitucional puder ser aplicada diretamente, os tribunais inferiores devem assim fazê-lo, não podendo invocar o argumento da falta da atuação legislativa. Aqui, o Tribunal poderia substituir-se ao legislador, até que sobreviesse a norma faltante ${ }^{393}$.

Quando se tratar de imposições não substituíveis, isto é, em que não pode haver a atividade "concretizadora" (Kokretisierung) dos Tribunais inferiores, a saída que resta ao Tribunal Constitucional é declarar a omissão inconstitucional do legislador, pois, em hipóteses desse jaez, correria o risco de o juiz substituir-se ao legislador.

Nada obstante, o que é importante ressaltar é que, embora a interpretação feita por Ignacio Villaverde Menéndez sobre a obra jurista alemão em comento tenha ido além do que este tenha querido realmente chegar, a ideia desenvolvida pelo primeiro estudioso é aproveitável para a identificação de um paradigma que qualifique as omissões legislativas.

Nesse sentido, haverá uma inconstitucionalidade por omissão toda vez que o legislador descumpra, pelo seu silêncio, uma obrigação derivada de uma reserva de lei

\footnotetext{
392 PESTALOZZA, Christian. "Noch verfassungsmässige" und "bloss verfassungswidrige" Rechtslagen. Zur Feststellung und Kooperativen Beseitigung verfassungsimperfekt Zustände. In: STARCK, Christian (org.). Bundesverfassungsgericht und Grundgesetz. Festgabe aus Anla $\beta$ des 25 jährigen Bestehens des Bundesverfassungsgerichts. Tübingen : Mohr, 1976, v. 1, p. 526 e ss.. Uma explicação, por necessária: o candidato, por mais que tivesse investigado, não conseguiu acesso ao texto do autor alemão citado. Por isso, as suas lições sobre o assunto foram recolhidas de outros autores que também o citaram e que não divergem entre si sobre o conteúdo daquele trabalho científico. Dito isso, a saída para demonstrar o que se pretende, foi citar o referido artigo pelo uso do apud. Assim: Apud SEGADO, Francisco Fernandez. El control de constitucionalidad de las omisiones legislativas... . Op. cit. p. 18; MENÉNDEZ, Ignacio Villaverde. La inconstitucionalidad por omisión, cit., pp. 99-100; RUIZ, Maria Angeles Ahumada. El control de constitucionalidad de las omisiones legislativas. Revista del Centro de Estudios Constitucionales, n. 8, jan/abr 1991, pp 180-182. Disponível em http://www.cepc.gob.es/publicaciones/revistas/fondohistorico?IDR=15\&IDN=1238\&IDA=35400. Acesso em 02/12/2014, às 15:00h.

${ }^{393}$ Apud RUIZ, Ahumada. El control de constitucionalidad de las omisiones legislativas. Op cit., p. 181. Ver também a classificação de omissões legislativa inconstitucionais no item 2.4.3.
} 
imperativa. Acredita-se que essa pode ser uma possível regra geral para o estabelecimento de um dever específico de legislar, haja vista que em hipóteses de reserva imperativa, a omissão legislativa não conta com o beneplácito da Constituição.

De pronto, por esse modo de ver as remissões ao legislador, diga-se, a princípio, que as reservas de lei dispositivas são aquelas que se identificam com as competências de legislar atribuídas pela Constituição. Sabe-se que essas normas são autorizações dadas pela Constituição ao Poder Público para emanar uma lei em relação a determinadas matérias ${ }^{394}$.

Ademais, pode-se concluir que as reservas dispositivas são as que também permitem ao legislador intervir em determinada situação jurídica prevista por norma que já tenha densidade normativa suficiente para ser aplicada de pronto. A lei, nesse caso, tem caráter redutor, daí por que normas com essas características já terem sido chamadas de restringíveis ${ }^{395}$.

Logo, nessa mesma categoria poderiam ser incluídas as normas permissivas ou facultativas, as quais, dada a sua apresentação linguística, geralmente apoiada no verbo "poder", também conferem liberdade ampla ao legislador, dado que a Constituição lhe confere tão-somente uma autorização. Delas são exemplos os artigos 22, parágrafo único ("lei complementar poderá autorizar os Estados a legislar sobre questões específicas das matérias relacionadas neste artigo"); 25, $3^{\circ}$ (“os Estados poderão, mediante lei complementar, instituir regiões metropolitanas, aglomerações urbanas e microrregiões, constituídas por agrupamentos de municípios limítrofes, para integrar a organização, o planejamento e a execução de funções públicas de interesse comum”); 39, §5 ("lei da União, dos Estados, do Distrito Federal e dos Municípios poderá estabelecer a relação entre a maior e a menor remuneração dos servidores públicos, obedecido, em qualquer caso, o disposto no art. 37, XI”); $125,3^{\circ}$ (“A lei estadual poderá criar, mediante proposta do Tribunal de Justiça, a Justiça Militar estadual, constituída, em primeiro grau, pelos juízes de direito e pelos Conselhos de Justiça e, em segundo grau, pelo próprio Tribunal de Justiça, ou por Tribunal de Justiça Militar nos Estados em que o efetivo militar seja superior a vinte mil integrantes"); 154, I (“A União poderá instituir: I - mediante lei complementar, impostos não previstos no artigo anterior, desde que sejam não-cumulativos

\footnotetext{
${ }^{394}$ Ver item 3.2.1.

395 Cf. BASTOS, Celso Ribeiro; BRITO, Carlos Ayres de. Intepretação e aplicabilidade das normas constitucionais. São Paulo : Saraiva, 1982, p. 51.
} 
e não tenham fato gerador ou base de cálculo próprios dos discriminados nesta Constituição"), etc. ${ }^{396}$.

Nessa perspectiva, se o legislador se silencia em relação às reservas de lei dispositivas, não haverá nenhuma consequência jurídico-constitucional, uma vez que a omissão é tolerada pela própria Constituição. Esse é o espaço em que o constituinte relegou ao legislador ampla liberdade decisória ${ }^{397}$.

Imperativas seriam as demais manifestações da Constituição que imponham um ônus ao legislador a fazê-lo. Se desconsideradas as fórmulas linguísticas utilizadas pela própria Carta Magna (“lei disporá”, "lei disciplinará”, “nos termos de lei”, etc), notar-se-á que as reservas de lei imperativas, tais como pensadas até o presente momento, compõem o critério que mais se aproxima do conceito de omissão inconstitucional pautado na vulneração de uma norma preceptiva não exequível por si mesma. Logo, esse modo de separar as omissões legislativas permitidas das que vulneram a Constituição se identificaria com o que pensa a doutrina brasileira sobre o assunto.

Contudo, acredita-se que, para a delimitação de uma reserva imperativa, não se pode desprezar a linguagem adotada pela Constituição. Para essa finalidade, pode-se depurar as diferentes terminologias que a Lei Fundamental utiliza quando faz uso da reserva de lei.

Com efeito, o interessado em ler a Constituição Federal de 1988 nela encontrará diferentes formas de remeter o tratamento de uma matéria ao legislador ${ }^{398}$. Na parte dos direitos e garantias fundamentais (Título II), como forma de "regulamentação" de um direito, que pode significar a restrição de seu gozo (e geralmente assim o é), utilizamse as tradicionais expressões "na forma da lei" (art. 5', VI, XXXII, XXXII, LXXVI, LXXVII; art. 7, XXVII; art. 12, II, “a”; art. 14, §§ $3^{\circ}$ e 11), "nos termos da lei” (arts. 5, VII, XXVIII; 7º, I, XII; caput do art. 14), “definida em lei” (art. 5o, XXVI). O

${ }^{396}$ Cf. SILVA, José Afonso da. Aplicabilidade das normas constitucionais, cit. p. 125.

${ }^{397}$ É que elas se traduzem, afinal, em "considerazioni e valutazioni di ordine politico, ideológico, economico - sottratte ad ogni possibilità di controlo giudiziario - a spingerlo ad agire o meno. Il vincolo costituzionale non lo stringe all'azione, ma opera solanto nel momento dello svolgimento dell'azione nel senso che il legislatore dovrà osservare certe forme e certe condizioni stabilite dai dettami della Costituzione. In sostanza, il legislatore ha la facoltà di emettere una determinata legge ma non ne ha l'obbligo; non facendo uso della facoltà, il legislatore rimane semplicemente inativo e non compie una omissione incostituzionale. Si parla in proposito di norme costituzionai facoltizzantti - ossia Ermächtigungsnormen" (Cf. TROCKER, Nicolò. Le omissioni del legislatore e la tutela giurisdizionale dei diritti di libertà. $O p$ cit, p. 102).

${ }^{398}$ Não se confundem remissão ao legislador com remissão à lei. No primeiro caso, está a Constituição a depender de atividade legislativa (interpositio legislatoris). No segundo, uma lei faz remissão a um dispositivo de seu próprio texto (remissão interna) ou a uma outra lei (remissão externa). Cf. MENDES, Gilmar Ferreira. Questões fundamentais de técnica legislativa. Op. cit., p. 19. 
direcionamento da Constituição à lei ordinária também ocorre de forma imperativa, como nas formas "lei estabelecerá" e (art. 50, XXIV) ou congêneres, como "na forma que a lei estabelecer" (art. 5 $\left.{ }^{\circ}, \mathrm{XII}\right)$,

Fora dali, a variedade terminológica das normas que fazem a supracitada remissão continua: sem a pretensão de detalhar todos os seus preceptivos, pode-se indicar que ora a Constituição determina que dado assunto será tratado "na forma da lei" ou "nos

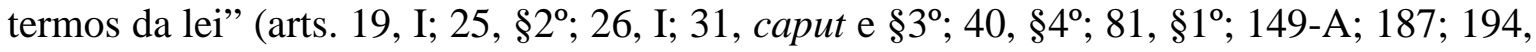
parágrafo único; $195 ; 200$, etc.); ora repete o discurso imperativo, ao dizer que a lei

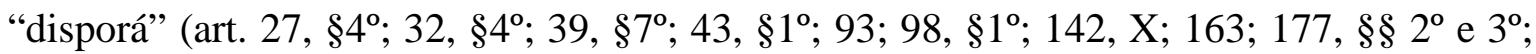
206, parágrafo único, etc.), ou "a lei estabelecerá” ou congêneres (art. 37, caput, I e IX, e $\S 5^{\circ} ; 45, \S 1^{\circ} ; 85$, parágrafo único; $128, \S 5^{\circ} ; 142, \S 1^{\circ} ; 165 ; 214$, etc.) ou a lei "regulará" (art. $20, \S 2^{\circ} ; 90, \S 2^{\circ} ; 190 ; 227, \S 2^{\circ}$, etc.) ou “disciplinará" (art. 37, §3º $39, \S 7^{\circ} ; 202, \S 4^{\circ}$, etc.) ou, ainda, "definirá" (art. 149, §4º $195, \S \S 10$ e 12; etc.).

A remissão também pode ser mais sutil, como acontece com os arts. $18, \S^{\circ}$, em que a criação de Municípios se dará por lei estadual, dentro do prazo estabelecido por lei complementar federal; 21, II, em que o trânsito de forças estrangeiras no território nacional se dará nos casos previstos em lei complementar; 37, XIX, pelo qual a lei complementar definirá as áreas de atuação de empresas públicas, de sociedade de economia mista e de fundação; 146, que diz caber à lei complementar dispor sobre conflitos de competência, em matéria tributária, entre a União, os Estados, o Distrito Federal e os Municípios; regular as limitações constitucionais ao poder de tributar; e estabelecer normas gerais em matéria de legislação tributária; 155, XII, que diz caber à lei complementar disciplinar o ICMS, quanto aos seus critérios pessoal e quantitativo, crédito, modo de concessão de benefícios fiscais, etc. Diga-se o mesmo em relação ao artigo 161, que estipula caber à lei complementar tratar de divisão entre os entes federativos de alguns tributos.

Como essa diversidade terminológica poderia justificar a enunciação de uma reserva de lei imperativa e, assim, cunhar um parâmetro para a definição de um dever de legislar? Volte-se ao que diz José Afonso da Silva.

Ele, ao observar essa diversidade de fórmulas com a qual a Constituição que orbita a reserva de lei, concluiu que, quando a Constituição utiliza o modo imperativo, como indicado acima, estar-se-á diante de uma reserva legal, ou melhor, reserva 
constitucional de lei absoluta. Por outro lado, quando emprega expressões como "nos termos da lei”, "no prazo da lei”, "na forma da lei”, "com base na lei”, "nos limites da lei”, “segundo critérios da lei”, estar-se-á diante de uma reserva constitucional de lei relativa ${ }^{399}$.

Pois bem. Excluídas as espécies classificatórias em si, por inaproveitáveis ao trabalho, mas servindo-se desse mesmo critério, que, afinal, ainda é o da intensidade da vinculação do legislador à Constituição, pode-se pensar que, diante de expressões como "lei disporá", "lei disciplinará" ou assemelhadas, o que o constituinte quer é reforçar a imposição de um dever específico ao legislador com a Constituição, atribuindo-lhe uma obrigação da qual este não poderá subtrair-se, pelo menos não sem assumir o risco de ver seu comportamento passivo sancionado como inconstitucional. O tom imperativo da Constituição reforçaria a proibição de o legislador omitir-se.

Ao contrário, quando remete a matéria ao legislador através de linguagem mais vaga, como "nos termos da lei", "na forma da lei”, etc., a vinculação do legislador à Constituição seria menos estreita. Neste caso, o que a Constituição deixa assente é a possibilidade de outros atos normativos inferiores à lei integrarem a norma, a partir de limites genéricos estipulados pela lei em sentido estrito.

Assim, pelo critério da reserva de lei, o dever específico de legislar decorreria de uma reserva imperativa, que, por sua vez, seria estreitamente delimitada também pela linguagem imperativa da própria Constituição.

\subsubsection{O critério político}

O critério da reserva de lei imperativa, para a definição de um dever específico de legislar, no entanto, não parece ser sempre aplicável de forma automática. É que certas normas constitucionais portam consigo características que as tornam infensas ao controle de constitucionalidade por omissão. Uma dessas características é o alto teor político. Nesses casos, nem mesmo diante de uma remissão imperativa de lei a omissão do legislador dá azo a uma omissão inconstitucional, porquanto não se pode falar que decorre de deveres que ocupam o campo jurídico-constitucional. A omissão está melhor situada, isso sim, ainda no campo político-constitucional.

De fato, já se argumentou com razão que "o erro do jurista puro ao interpretar a norma constitucional é querer exatamente desmembrá-la de seu manancial político e

${ }^{399}$ Cf. SILVA, José Afonso. Curso de direito constitucional positivo, cit, pp. 426. 
ideológico, das nascentes da vontade política fundamental, do sentido quase sempre dinâmico e renovador que de necessidade há de acompanha-la" ${ }^{400}$. A consequência desse modo simples, mas de retidão indiscutível de ver a realidade constitucional é esta: "a interpretação constitucional se move, pois, no plano delicado da dicotomia a que nos temos referido: de uma lado, o jurídico, doutro, o político, ambos porém decisivamente importantes, demandando a única solução possível: o equilíbrio desses dois pratos da balança constitucional" ${ }^{\prime 401}$.

A essa altura do trabalho, está claro que o dever específico de legislar decorre da vinculação do legislador à Constituição, mas que a natureza dessa vinculação não é só jurídica. É também política e, como se verá abaixo, em alguns casos, sobretudo política.

Note-se bem. Quando se admite uma forte vinculação política, isso não quer dizer que a norma constitucional não tenha eficácia jurídica. Não é isso que se afirma. Toda norma constitucional, por ser jurídica, irradia efeitos jurídicos. O que acontece é que delas não se extraem um dever específico de legislar, isto é, não dizem quando, nem como nem se legislar, pois isso cabe somente ao legislador decidir. Mas, uma vez legislada, a matéria passa a sofrer os influxos da vinculação jurídica (e estritamente jurídica). Nestes casos, os efeitos jurídicos da norma constitucional operam como parâmetro negativo para o legislador, isto é, ele não é livre para definir de modo inteiramente discricionário o conteúdo da lei ordinária. Ele deve ater-se às balizas fixadas pela Constituição. Disso decorre que toda norma constitucional pode funcionar como parâmetro para o controle de constitucionalidade, mas não necessariamente ao controle de constitucionalidade por omissão.

Esclarecido esse ponto, faz-se mister avançar. A relação entre Constituição e Política nem sempre se modela por esquemas rígidos de normatividade, mesmo que se considere a primeira como "o estatuto jurídico do político". Com isso pretende-se apenas deixar assente que há, quanto à eficácia de certas normas constitucionais, maleabilidade jurídico-normativa da Constituição frente a dadas controvérsias que se situam dentro de âmbitos temáticos que envolvem unicamente escolhas políticas. Recorde-se que "a constituição como fato jurídico é estreitamente ligada (legata a filo doppio) à constituição

\footnotetext{
${ }^{400}$ Cf. BONAVIDES, Paulo. Curso de Direito Constitucional cit., p. 461.

${ }^{401}$ Cf. BONAVIDES, Paulo. Curso de Direito Constitucional, cit., p. 463.
} 
como fato político"402. Relacionam-se de modo a condicionarem-se mutuamente. "Não existe verdadeira garantia da Constituição se esse vínculo é ignorado ou desprezado [e] a mais abstrata e impolítica interpretação da constituição poderia resolver-se não na máxima garantia dessa última, mas na sua ruína"403.

Quando aquelas controvérsias ocorrem, pode-se pensar num critério político para a determinação de uma omissão como comportamento constitucional ou inconstitucional. Esse parâmetro tem fundamento teórico na doutrina das questões políticas. De acordo com essa teoria, a resolução daqueles conflitos deve ser deixada exclusivamente ao alvedrio do responsável pela tomada de decisões políticas. A Corte deve, então, abster-se de examiná-las. Bem de ver que essa teoria liga-se umbilicalmente ao princípio da separação de poderes ${ }^{404}$.

Naturalmente que, tratando-se de uma atividade de autocontenção e pelas dificuldades de se fixarem critérios objetivos e definitivos sobre o que seja de fato uma questão puramente política, foram, e sempre o serão, os órgãos de cúpula da jurisdição constitucional os responsáveis por delineá-las, restando "livre[s] para manipular tais parâmetros a seu gosto" $" 405$.

${ }^{402}$ Cf. ZAGREBELSKY, Gustavo; MARCENÒ, Valeria. Giustizia Constituzionale, cit, p. 120. Do original: "la costituzione come fatto giuridico è legata a filo doppio alla costituzione come fatto politico" e "Non vi è vera garanzia della costituzione se questo nesso viene ignorato ou disprezzato".

${ }^{403}$ Cf. ZAGREBELSKY, Gustavo; MARCENÒ, Valeria. Giustizia Constituzionale, cit, p. 120. Do original: "Non vi è vera garanzia della costituzione se questo nesso viene ignorato ou disprezzato" [e] "la più astratta e impolitica interpretazione della costituzione potrebbe risolversi non nella massima garanzia di quest'ultima, ma nella sua rovina".

${ }^{404}$ É interessante notar que os autores italianos supracitados encaram as questões políticas sob o ângulo da sensibilidade do juiz constitucional quanto ao momento de julgar determinada matéria que pode ter forte carga política. Isso quer dizer que, de todo modo, não há nenhum assunto sobre o qual a Corte não possa pronunciar-se. O que releva ressaltar é construção teórica por eles erigida. Após descreverem modos de atuação com base na construção weberiana da ética das convicções e da ética da responsabilidade, aduzem que os juízes constitucionais devem manter a coerência e atuarem sempre conforme a ética dos princípios (ética das convicções), isto é, aplicar a Constituição sem se atentarem às consequências disso (seja, essas políticas, jurídicas, econômicas, etc.). Contudo, há certos casos da vida constitucional que, pela sua ocorrência extraordinária, devem leva-los a confrontar as conviç̧ões com as consequências. Isso não quer dizer que a ética dos princípios implique falta de responsabilidade, bem como a ética da responsabilidade deva coincidir com oportunismo da falta de princípios. É evidente que a lição weberiana é feita sob encomenda para os políticos. Mas "quando o direito e a política não se distinguem; quando na constituição aparece o 'direito político', vale também para o juiz constitucional" (Cf. ZAGREBELSKY, Gustavo; MARCENÒ, Valeria. Giustizia Constituzionale, cit, p. 120).

${ }^{405}$ Cf. LEAL, Roger Stiefelmann. O efeito vinculante na jurisdição constitucional, cit. p. 32. Há quem entenda, por outro lado que, em alguns casos, a questão é inerentemente política, não cabendo sequer ao Poder Judiciário oferecer-lhes limites. É o caso de Alexander Bickel, para quem nas questões políticas, caracterizadas por critério de conveniência política e não por princípios gerais (caso em que seriam questões jurídicas), a atuação da jurisdição constitucional é antidemocrática, por imiscuir-se em assuntos concernentes a assuntos de governo ou do próprio eleitorado, como se deu em Colegrove vs. Green (Cf. BICKEL, Alexander M. The Least Dangerous Branch. The Supreme Court at the Bar of Politic. New Haven e Londres : Yale University Press, $2^{\mathrm{a}}$ ed., 1986, pp. 183-197). 
A origem desse modo de compreender o fenômeno político no âmago da Constituição é tão vetusta quanto o próprio controle de constitucionalidade. Com efeito, o julgamento de Marbury vs. Madison, em 1803, trouxe à Constituição americana uma garantia e ao Judiciário, um poder e um limite. A garantia refere-se obviamente à instauração do judicial review. O poder diz respeito à legitimidade de efetuar a aferição de constitucionalidade, o que já houvera sido defendido nos federalist papers $\mathrm{n}^{\mathrm{o}} 78$ e $81^{406}$, os quais podem ser concebidos como uma espécie de justificação teórica prévia do instituto $^{407}$. O limite concerne à vedação de ingressar no campo exclusivo da política.

Na famosa decisão, o Chief Justice Marshall considerou que há um domínio de poderes do Governo e do Congresso que é impenetrável à autoridade da justiça. A Constituição dos Estados Unidos investe o Presidente de determinados poderes políticos, “em cujo exercício ele só recorre à sua discrição e só responde perante as leis de seu país

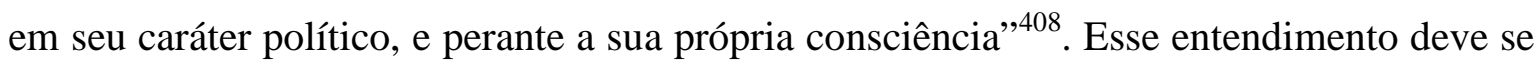
estendido aos funcionários que lhe são subordinados. Em casos desse jaez, não haveria outro poder que pudesse supervisionar, dirigir essa discricionariedade, porque os assuntos são políticos, e não relacionados a direitos individuais.

Nos Estados Unidos, a abrangência da doutrina das questões políticas alterouse com o tempo. De uma aplicação quase sem limites, em que praticamente qualquer competência do Poder Executivo podia ser interpretada como exclusivamente política, em julgados seguintes, a Suprema Corte procurou "sistematizar" o seu cabimento.

Emblemática, nesse sentido é a decisão Baker vs. Carr, de 1962, que a referida doutrina ganhou uma "padronização", pelo voto do juiz Brennan. Este delineou a utilização da doutrina com base nos seguintes critérios: a) a atribuição de uma textual competência constitucional a uma instância política; b) falta de critérios jurídicos para resolver a questão; c) impossibilidade de decidir sem que se utilize, inicialmente, argumentos fora da discricionariedade judicial, isto é, marcadamente políticos; d) impossibilidade de a Corte tomar uma decisão sem expressar falta de respeito aos outros

\footnotetext{
${ }^{406}$ Cf. HAMILTON, Alexander; JAY, John; MADISON, James. O federalista. São Paulo : Russell Editores, 2010, pp. 477-483 e 495-503.

407 Isso não significa, porém, que eram ignorados, naquela época, elementos básicos do controle de constitucionalidade, isto é, e em termos gerais, a conformidade da legislação inferior em função de uma Lei Maior que lhe serve de paradigma. Para maior detalhamento desse tema, conferir: LEAL, Roger Stiefelmann Leal. $O$ efeito vinculante na jurisdição constitucional, cit., p. 19; CAPPELLETTI, Mauro. $O$ controle de constitucionalidade das leis no direito comparad. Porto Alegre: Sergio Antônio Fabris Editor, 1992, p. 6062); e CORWIN, Edward. The "higher law background” of American Constitucional law, cit., p. 62.

${ }^{408}$ MARSHALL, John. Decisões Constitucionais de Marshall. Tradução de Américo Lobo. Ministério da Justiça, 1997, p. 14. A transcrição obedeceu as regras do vernáculo atualmente vigentes.
} 
poderes; e) necessidade incomum de aderir de forma inquestionável a uma decisão política já tomada; f) potencialidade de constrangimento de diferentes pronunciamentos feitos por vários departamentos sobre uma questão ${ }^{409}$. Cuida-se de evidente tentativa de estabelecer fundamentos teóricos para limitar a liberdade da Suprema Corte em autoconter-se ou não, ou, por outras palavras, de racionalizar as decisões da Corte nessa seara.

Em tempos mais recentes, a aplicação da doutrina das questões políticas foi levantada, ainda nos Estados Unidos, sobre controvérsias envolvendo gerrymandering, isto é, modos contestáveis de delimitação de distritos eleitorais, realizados de tal forma a propiciar um benefício inapropriado a um partido em especial ${ }^{410}$. Vieth vs. Jubelirer, de 2004, é exemplo nesse sentido. Na ocasião, os Justices Scalia, O'connor e Thomas consideraram não haver critérios jurídicos que pudessem ser empregados pelo judiciário para resolver redefinir distritos eleitorais ${ }^{411}$. Mencionem-se, ainda,

No Brasil, pelo menos nos primeiros julgados, a doutrina das questões políticas foi aplicada como justificativa para a manutenção da ordem constitucional, num tempo em que havia uma desconcertante fragilidade política das instituições nacionais. José Elaeres Marques Teixeira assevera que, na Primeira República, a doutrina foi invocada para que o Tribunal deixasse de julgar, casuisticamente, conflitos de ordem político-institucional, relegando ao Poder Legislativo a responsabilidade de resolvê-los. Mas, dada a "índole submissa" desse Poder, as questões eram deixadas nas mãos do titular do Poder Executivo, que era a instância que concentrava, de fato, o poder de mando ${ }^{412}$.

Anteriormente, neste trabalho, assentou-se que as Constituições europeias advindas a partir do segundo pós-guerra impuseram-se à lei. $\mathrm{O}$ direito constitucional irradia-se por todo o espectro político e social. A Constituição, como ordem aberta, aceita

\footnotetext{
409369 U.S. 586 (1962). Cf. TRIBE, Lawrence H. American Constitucional Law. $3^{\mathrm{a}}$ ed. Nova Iorque : Foundation Press, 2000, p. 366. No original: "Prominent on the surface of any case held to envolve a political question is found": 1) "a textually demonstrable constitutional commitment to a cordinate political department"; 2) "a lack of judicially discoverable and manageable standards for resolving it"; 3) "the impossibility of deciding without an initial policy determination of a kind clearly for nonjudicial discretion"; 4) "the impossibility of a court's undertaking independente resolution without expressing lack of respect due coordinate branches of government; 5) "an unusual need for unquestioning adherence to a political decision already made"; 6) "the potentiality of embarrassment from multifarious pronouncements by vários departments on one question".

${ }^{410}$ Cf. WEAVER, Michael. Uncertainty Maintained: The Split Decision Over Partisan Gerrymanders in Vieth v. Jubelirer. Loyola University Chicago Law Journal, vol. 26, 2005, p. 1287. Disponível em http://www.luc.edu/media/lucedu/law/students/publications/llj/pdfs/weaver.pdf, consultado em 19/09/2014, às 20:00h.

411 541 U.S. 267 (2004).

${ }^{412}$ Cf TEIXEIRA, José Elaeres Marques. A doutrina das questões políticas no Supremo Tribunal Federal. Porto Alegre : Ségio Antônio Fabris Editor, 2005, p. 157.
} 
os conflitos oriundos dos antagonismos de visão de mundo que necessariamente permeiam a sociedade plural, buscando um esforço comum para engendrar, através de um compromisso, um desenho social e político geral $^{413}$. A garanti-la está a jurisdição constitucional, que conquista, por isso, posição de protagonismo no Estado Constitucional $^{414}$.

Tendo sido inspirada nas Constituições europeias da segunda metade do século XX, sobretudo a portuguesa de 1976, é de se indagar se (a) ainda se justifica a aplicação da doutrina das questões políticas na Constituição de 1988, e (b) em caso positivo, qual o espaço que o Supremo Tribunal Federal tem àquela doutrina reservado.

As respostas vêm em ordem contrária. Em relação à segunda indagação, digase que a atuação do STF, num primeiro momento, foi de autocontenção em controvérsias relativas, por exemplo, à identificação dos requisitos para a edição de medidas provisórias, a não ser que a falta de tais requisitos possam ser objetivamente aferíveis, caso em que poder-se-ia evidenciar excesso de poder ${ }^{415}$; decisões tomadas pelo Congresso Nacional em processos de impeachment ${ }^{416}$; expulsão de estrangeiro ${ }^{417}$; concessão de anistia ${ }^{418}$.

Atualmente, consigne-se que a doutrina das questões políticas está em franco desuso, ainda mais pelo ativismo exacerbado dos últimos anos do Supremo Tribunal

\footnotetext{
${ }^{413}$ Cf. ZAGREBELSKY, Gustavo; MARCENÒ, Valeria. Giurisdizione costituzionale, cit, p. 50.

414 Sobre esse aspecto, Juan Luís Requejo Pagés destaca que as remissões do sistema normativo constitucional sempre se farão expressa ou tacitamente. O que cabe salientar é que as determinações constitucionais "sólo alcanzan su definitivo estado tras la sucessiva serie de decisiones con las que los actores por ellas apoderados en las fases inferiores terminan por definir sus contenidos”. Esse processo de trânsito entre a total abstração da norma constitucional até a sua máxima concretização, representada pela decisão judicial, dá àquele sistema normativo um caráter dinâmico, cuja consequência pode ser a perda de contornos precisos entre as diferentes fases de concreção da norma e definição de seu conteúdo normativo. Quer com isso dizer que a atuação dos órgãos jurisdicionais, e em especial do Tribunal Constitucional, é, em última análise, a que vai decidir com caráter definitivo o conteúdo último de cada norma estabelecida em cada um dos enunciados anteriormente elaborados. Com isso ele conclui que é a "sentença" o único ato em que se identificam as verdadeiras normas constitucionais em cada momento histórico (Cf. PAGÉS, Juan Luis Requejo. Sistemas normativos, Constitución y Ordenamento. La Constitución como norma sobre la aplicación de normas. McGraw-Hill, 1995, p. 51, nota 11; PAGÉS, Juan Luis Requejo. Constitución y remisión normativa. Perspectivas estática y dinámica en la identificación de las normas constitucionales. Revista Española de Derecho Constitucional. Año 13. Núm. 39. Septiembre-Diciembre 1993, p. 124).

415 Além da ADI supracitada: ADI n 162-MC/DF, DJU 14/12/89 (nesse julgado, o STF não reconheceu o excesso de poder de legislar, conquanto tenha reconhecido que não estavam presentes os requisitos ensejadores da edição da medida provisória) são exemplos: ADIs no 526-MC/DF, DJU 05/03/93; n 1397 MC/DF, DJU 28/04/97; no 1717-MC/DF, DJU 22/09/1999; nº 1753-MC/DF, DJU 16/04/98; n 2.150/DF, DJU 11/09/2002.

${ }^{416}$ Por exemplo: MS no 20.941/DF, DJU 31/08/92. Mas nos MS no 21.564, DJU 27/08/93 e nº 21.689, DJU 07/04/95 (caso Collor), o Tribunal entendeu que o Poder Judiciário é competente para conferir proteção das garantias do devido processo legal.

${ }_{417} \mathrm{HC} \mathrm{n}^{\circ} 68.402 / \mathrm{DF}$, DJU 16/10/92

${ }^{418} \mathrm{ADI} \mathrm{n}^{\circ}$ 2.306/DF, DJU 31/10/2002; ADI no 1231, DJU 28/04/2006. A consulta de todos os julgados acima foi feita tomando-se como ponto de partida a obra já citada de José Elaeres Marques Teixeira.
} 
Federal. Nesse sentido, a Corte, no RE no 197.917/SP ${ }^{419}$ (caso "Mira Estrela"), declarou parcialmente inconstitucional a Lei Orgânica daquele Município, fixando um critério para a delimitação do número de vereadores. São também emblemáticas as ADIs $n^{\circ} 1351^{420}$ e $n^{\circ}$ $1354^{421}$, em que julgou inconstitucional a "cláusula de barreira" imposta pela lei $\mathrm{n}^{\circ}$ 9.065/96. Frise-se que, na ADI $n^{\circ} 958 / \mathrm{RJ}^{422}$, o Supremo houvera rechaçado a referida cláusula criada pela lei no ${ }^{\circ} 8.713 / 93$.

Sobre a primeira indagação, há severos argumentos que depõem contra a aplicação dessa doutrina. Em primeiro lugar, não caberia a enumeração das hipóteses ou exemplos de questões políticas na Constituição, porque não existem casos ratione materiae, mas tão-somente regras de competência. "Toda discricionariedade é interior, é 'dentro'; nesse branco, que as raias das atribuições concedem, é que o aspecto ou a dimensão é só concernente política". Ademais, "a justiça limita-se a decidir sobre os direitos individuais. Quando se diz que lhe não compete resolver sobre questões políticas, o que se entende afirmar é que não se pode intrometer em assuntos, encarregados, pela Constituição, ou pelas leis, à discrição de outro poder" ${ }^{423}$. Assim, os atos praticados em exorbitância dessa competência poderiam ser naturalmente objeto de apreciação judicial.

A mesma seara percorre Lourival Vilanova, para quem não há falar-se em fato político sem qualificação jurídica. Para ele não existe questão exclusivamente política, a não ser as procedentes do fato político constituinte, que "somente se qualificam a posteriori, pela legitimação da Constituição posta, que retroincide no suporte factual que lhe deu origem". A seu ver, a qualificação de questões como exclusivamente políticas é dada pelo Poder Judiciário, como preliminar que afasta seu exame pelo mesmo Poder: o Poder Judiciário não deixa de ajuizar a questão por ser política, mas a questão é política porque o Judiciário não a aprecia, por tratar-se de uma questão de estratégia, política prudencial de que se vale a Suprema Corte dos Estados Unidos para afastar-se dos conflitos de interesses que escapam à mera técnica de apreciar jurisdicionalmente as controvérsias $^{424}$.

\footnotetext{
${ }^{419}$ DJU 07/05/2004.

${ }^{420}$ DJU 30/03/2007.

${ }^{421}$ DJU 29/06/2007.

${ }^{422}$ DJU 25/08/95.

${ }^{423}$ Cf. MIRANDA, Francisco Cavalcanti Pontes de. Comentários à Constituição de 1946. Tomo III. Rio de Janeiro : Editor Borsoi, 1960, pp. 205-206. No mesmo sentido: CAMPOS, Francisco. Direito Constitucional. II Volume. São Paulo e Rio de Janeiro : Livraria Freitas Bastos S/A, 1956, p. 402.

${ }^{424}$ Cf. VILANOVA, Lourival. A dimensão política nas funções do Supremo Tribunal Federal. Revista de Direito Público. Ano XIV, ns. 57-58. São Paulo : Editora Revista dos Tribunais. Jan-jun 1981, pp. 52.
} 
Acresça-se ainda que, dada a dificuldade de delimitação teórica, pela própria do conceito de questão política (é questão política aquilo que a jurisdição constitucional entende que seja), essa doutrina não poderia ser levada em conta como um critério científico-dogmático apto a aferir a vulneração ou não da Constituição. Portanto, se a falta de critério pode levar a um ativismo judiciário, por outro lado poderia resultar num passivismo também infenso à supremacia constitucional ${ }^{425}$.

As críticas levantadas contra a doutrina das questões políticas são, com efeito, robustas e pertinentes. É extremamente difícil elencar os casos em que se está diante de uma questão eminentemente política. Se, de fato, houver a lesão a alguma norma por extravasamento da competência de quaisquer dos Poderes, a questão tornar-se-á apreciável judicialmente. Não há ainda critérios seguros a dizer com certeza quando ocorrem essas questões políticas. E, à evidência, não será um artigo de Constituição (tal como fez a de 1934, em seu artigo 68 ou a de 1937, em seu artigo 94) ou um preceito legal (como fez a lei italiana $n^{\circ} 87 / 53$, em seu art. 28) que irá eliminar esse problema conceitual. Mas, por outro lado, esses preceitos traduziram-se em indicativos da preocupação do poder constituinte de cada época em preservar as prerrogativas de cada poder e reforçar a existência desse tipo de problema político.

Deste modo, não é a crítica a essa doutrina que fará desaparecer questões de natureza política. Elas ainda estão lá, na Constituição, e, por isso, ainda podem, a depender da matéria analisada, justificar o estabelecimento de um critério para julgar a omissão legislativa como inconstitucional ou não. Talvez, os critérios elencados em Baker vs. Carr possam inspirar o STF a também formular certos parâmetros para adoção desta doutrina.

Pontes de Miranda diz que haverá questão jurídica quando a prática de atos (ou exceções) de quaisquer dos poderes ferir direitos públicos ou privados ${ }^{426}$. Talvez este seja um critério aproveitável, embora imperfeito. Nesse sentido, faz-se mister trazer à colação lição irretorquível de Paulo Bonavides. Ele descreve inicialmente a lição de Rui Barbosa, esposada no texto $O$ Direito do Amazonas ao Acre Setentrional, na qual o autor baiano destaca que questões políticas, caracterizadas sob o critério de conveniência e oportunidade política, não estariam isentas do exame judicial se lesivas a direitos individuais. Compreende, então, que Poder Judiciário, quando reconhece atos legislativos que ofendem a Constituição, traça limites eficazes à onipotência do Estado, “desarmando-o (...) daquele

\footnotetext{
${ }^{425}$ RAMOS. Elival da Silva. Ativismo judicial. Parâmetros dogmáticos, cit., pp. 150-151.

${ }^{426}$ MIRANDA, Francisco Cavalcanti Pontes de. Comentários à Constituição de 1946. Tomo III, cit, p. 206.
} 
poder soberano de impor aos governados uma vontade sem freios"427. E conclui que a esfera material ao alcance dos juízes e tribunais diz respeito a dos direitos individuais, "não obstante a dimensão política e a relatividade que tais direitos tomaram nas vigentes concepções do Estado Social”428. Assim, o que Rui Barbosa escrevera na vigência do liberalismo não se alterou perante as exigências do Estado Social ${ }^{429}$. Isto é, o reconhecimento de questões políticas ainda é permitido pelo constitucionalismo democrático.

Essa visão parece aceitar que "tanto o Executivo quanto o Legislativo podem tomar conta dos respectivos processos de decisão, bem como defender suas prerrogativas em caso de violação" ${ }^{\text {430 }}$. Deste modo, cabe apenas ao Judiciário proteger os limites substantivos impostos pela Constituição, sobretudo em relação aos direitos individuais.

$\mathrm{Na}$ ADI no 1516-MC/UF ${ }^{431}$, os Ministros Sepúlveda Pertence e Maurício Correa sinalizaram orientação nesse sentido. Nos debates, este último justificou a questão política envolvendo os requisitos de relevância e urgência nas medidas provisórias pelo fato de que "tudo depende da vontade do Congresso Nacional". Já aquele sentenciou que "há determinados momentos em que o Congresso não quer assumir - e isso é uma medida legítima do seu poder político - a responsabilidade de endossar determinada legislação”.

No que concerne à atividade legiferante, a conclusão segundo a qual o produto do processo legislativo se verga, desde logo, à possibilidade de ser objeto do controle de constitucionalidade é óbvia. Nada obstante, também é lícito considerar que, em alguns casos, a decisão de não legislar haverá que ser interpretada como o exercício de uma prerrogativa política legítima, não apreciável judicialmente. E isso ocorrerá mesmo que se esteja diante de normas constitucionais que contenham uma remissão expressa ao legislador. Repise-se o argumento: como a Constituição pluralista admite sempre o conflito político, deverá também ela respeitar um espaço legítimo para as escolhas políticas ${ }^{432}$. ${ }^{427}$ BONAVIDES, Paulo. Curso de Direito Constitucional. Malheiros Editores, $24^{\mathrm{a}}$ ed. 2009 , p. 322.
${ }^{428}$ Cf. BONAVIDES, Paulo. Curso de Direito Constitucional, cit., p. 323 .
${ }^{429}$ Cf. BONAVIDES, Paulo. Curso de Direito Constitucional, cit, p. 324 .
${ }^{430}$ Cf. PINTO, Marcos Barbosa. Jurisdição Constitucional e Democracia. (tese de doutorado). USP, 2008, p.
140 . Sabe-se que a tese consultada foi publicada pela editora Renovar, em 2009.
${ }^{431}$ DJU 13/08/99. Nessa ação discutiu-se a reedição de Medida Provisória que alterava o artigo 44 da Lei no
$4.771 / 65$ (Código Florestal). Conferir também em: PINTO, Marcos Barbosa. Jurisdição Constitucional e
Democracia, cit, p. 140.
${ }_{432}$ Dada a pertinência da lição com o assunto tratado, pede-se vênia para mais uma vez citar Gustavo
Zagrebelsky e Valeria Marcenò: "le costituzioni democratiche che riconoscono la libertà e il conflitto
politico, come motore della vita pubblica - cioè ammettono la libertà di opinione politica, il pluralismo dei
partiti, elezioni competitive ecc. - devono però rispettare anche uno spazio vuoto che stia dopo la
Costituzione: lo spazio legittimo della politica e delle 'scelte discrezionali', di cui parla per esempio l'art. 28 
Não se deve legislar sem necessidade. Se leis supérfluas ou repetitivas devem ser evitadas ${ }^{433}$, diga-se o mesmo em relação às leis inócuas. Por isso mesmo, não há dúvidas, por exemplo, que a organização e o funcionamento do Conselho da República haverá que obedecer à necessidade. E a decisão de quando (ou se) criá-lo atenderá a critérios políticos, porque política é a sua atuação, do que se vê das atribuições dispostas no art. 90, da Constituição. Assim, mesmo que o $\$ 2^{\circ}$ desse dispositivo diga que "a lei regulará" (norma preceptiva não exequível por si mesma, claro está) disso não se pode extrair, per se, um dever de legislar. Portanto, o silêncio legislativo nesse assunto não terá a menor relevância constitucional.

Esse é o momento de fazer referência a um caso de preponderante teor político, apreciado pelo STF e que não teve, ao final, resultado satisfatório, porque o Tribunal realizou ingerência jurídica numa questão tipicamente política, ainda que a Constituição fizesse remissão expressa à lei (reserva de lei complementar). Trata-se do objeto da já conhecida ADI 3.682/MT. Nesta ação, o STF julgou inconstitucional o silêncio do legislador, por não ter sido produzida a lei complementar exigida pelo art. $18, \S 4^{\circ}$, na redação dada pela Emenda $n^{\circ} 15 / 96$, norma considerada pelo mesmo Tribunal, como lembrado pelo Ministro Relator, como de eficácia limitada (conforme classificação de José Afonso da Silva). Reconheceu que a frustração de um dever de legislar seria patente também em função da pletora de municípios que foram criados sem o devido tramento legislativo à matéria.

Em seu parecer, o Procurador-Geral enunciara que a demora em mais de dez anos para a edição da lei complementar feria a Constituição em sua "literalidade e espírito". Assim, o silêncio do legislador federal comprometia a autonomia federativa de Estados e Municípios, haja vista que ficariam incapacitadas de organizar a distribuição do poder político-administrativo em seus territórios.

della lege n. 87 del 1953, per riservarle al legislatore e sotrarle alla Corte costituzionale. Ciò riguarda le materie che, pur rientrando nel compromisso costituzionale, sono oggetto di normazione di principio e devono pertanto poter essere sviluppate secondo indirizzi differenti, soprattutto quando i principi siano plurimi e intrecciati e dunque debbano essere combinati tra loro. In queste ipotesi, manca una riconoscibile o determinabile regola di giudizio sostantiva e quindi il caso dovrà ritenersi non giuridicamente definibile $o$, meglio, dovrà essere definito attraverso una pronuncia in limine che attesti l'esistenza della discrezionalità del legislatore e quindi il dovere del giudice costituzionale de arrestarsi prima di oltrepassarlo. Si potrebbe, in questo caso, parlare di 'questione politica', nel senso di questione non giustiziabile per carenza di standard costituzionali di riferimento" (Cf. Giurisdizione costituzionale, cit, p. 119).

${ }^{433}$ Cf. MENDES, Gilmar. Questões fundamentais de técnica legislativa. Revista eletrônica sobre a reforma do Estado (RERE). Salvador : Instituto Brasileiro de Direito Público, $\mathrm{n}^{\circ} 11$, set/out/nov 2007, p. 3. Disponível em http://www.direitodoestado.com.br/rere.asp. Consultado em 11/12/2014, às 16:00h. 
Esse de fato parece ser o cerne da questão. O poder constituinte reformador, ao alterar o tipo de lei necessária para o "fechamento" da norma constitucional, na verdade pretendeu dificultar ao máximo a criação de novos municípios. Isso é particularmente perceptível pela própria supressão da competência das Assembleias dos Estados para deliberar sobre o tema, transferindo-a ao Congresso Nacional. E a razão de ser da imposição de um processo mais complexo foi estampada logo no início da exposição de motivos do Projeto de Emenda Constitucional no 41/91, proposição originária da Emenda n 15/96: "o aparecimento de um número elevado de municípios novos, no País, tem chamado a atenção para o caráter essencialmente eleitoreiro que envolve suas criações, fato este lamentável"434. Com a alteração constitucional, o Congresso compreendeu a mensagem enviada pelo poder constituinte reformador, simplesmente não legislando, porque a atitude esperada por este era essa mesma: barrar a criação de novos municípios.

Com a comunicação da declaração de inconstitucionalidade por omissão enviada pelo Supremo Tribunal Federal, inclusive mediante o estabelecimento de um prazo para a promulgação da lei complementar a que fazia menção o artigo $18, \S^{\circ}$, o Congresso acabou por aprovar o PLS 98/2002, posteriormente vetado pelo Chefe do Executivo, em 2013. Ressalte-se que o veto não se deu por inconstitucionalidade, mas por interesse público. Considerou-se que o aumento de despesa ocasionada pelo eventual acréscimo do número de municípios não seria acompanhado de um aumento de receitas. Além disso, haveria "maior pulverização na repartição dos recursos do Fundo de Participação dos Municípios - FPM, o que prejudicará principalmente os municípios menores e com maiores dificuldades financeiras"

Seguiu-se nova tentantiva, desta vez com o PLS 104/2014, com a descrição pormenorizada dos requisitos a serem cumpridos para a criação de novo município. Esta também foi obstacularizada por novo veto, agora em 2014, praticamente sob os mesmos fundamentos do veto anterior ${ }^{436}$. Assim, o STF, sob o desiderato de impelir o Congresso a completar a Constituição, pôde ver que o caráter jurídico subjacente à norma constitucional não superou a índole marcadamente política da questão por ele tratada.

Outra hipótese em que é, no mínimo, discutível a atuação do STF tem a ver

\footnotetext{
${ }^{434}$ Disponível em http://www.camara.gov.br/proposicoesWeb. Consultado em 19/12/2014, às 11:00h.

435 Mensagem de veto $\mathrm{n}^{\circ}$ 505/13. Disponível em http://www.planalto.gov.br/ccivil_03/_Ato20112014/2013/Msg/Vet/VET-505.htm. Acesso em 19/12/2014, às 11:00h.

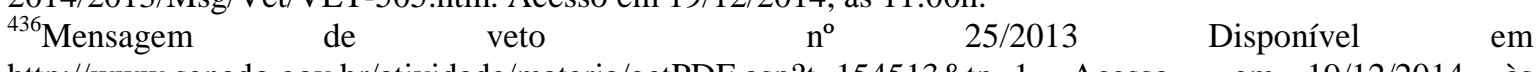
http://www.senado.gov.br/atividade/materia/getPDF.asp?t=154513\&tp=1. Acesso em 19/12/2014, às 12:00h.
} 
com a fixação do número de deputados por unidade da federação, prevista no art. $45, \S 1^{\circ} \mathrm{e}$ objeto das ADIs nos 4947/DF, 4.963/DF, 4.965/DF, 5.020/DF, n 5130/DF e 5.028/DF ${ }^{437}$.

Antes delas, o dispositivo fora objeto do $\mathrm{MI} \mathrm{n}^{\mathrm{o}} 219^{438}$. Na ocasião, o Tribunal declarara a mora ao legislador e comunicara esse fato ao Congresso (ainda era corrente o entendimento de que mandado de injunção e ação declaratória de inconstitucionalidade por omissão possuíam os mesmos efeitos, na esteira do que fora julgado no MI 107/QO).

Nesse writ, o que releva ressaltar é a intervenção do Ministro Sepúlveda Pertence no debate havido entre os Ministros Moreira Alves e Marco Aurélio, em torno da definição do número de deputados, mormente a possibilidade de se aumentar o número de deputados do Estado de São Paulo para 70. O primeiro Ministro salientara que esse era um problema político, haja vista que, se o número de deputados daquela unidade da federação tivesse sido aumentado, bancadas de outras unidades teriam sofrido diminuição. Asseverou então o Ministro Sepúlveda Pertence que "aquele era um problema político dos mais sérios. Desde a Comissão Afonso Arinos (...), os interesses regionais, as vinculações naturais fizeram, da discussão a propósito, uma das mais dramáticas daquela Comissão". Ato contínuo, arrematou: "a fórmula do art. 45 foi daquelas composições de adiamento de um problema" e "chegar ao teto foi uma opção política do Congresso".

Naquelas ADIs, o Ministro Gilmar Mendes levou essa advertência em consideração, e afirmando a tradição trazida de deixar-se a fixação do número de deputados a cargo da justiça eleitoral, que viera desde a Carta de 1891 (a única que assim não previa era a Constituição de 1988), rejeitou os pedidos de declaração de inconstitucionalidade (as ações foram julgadas em conjunto). Nada obstante, o STF decidiu que, conquanto houvesse a lei complementar prevista pelo dispositivo - lei complementar n $78 / 03$ - o legislador se omitiu em estabelecer critérios para a fixação do número de parlamentares para cada Estado, dado que o parágrafo único do art. $1^{\circ}$ da referida lei.

Na espécie, considerou-se que não poderia haver delegação dessa tarefa ao Tribunal Superior Eleitoral, pois a norma constitucional não autorizava essa delegação. Declarou, por isso, também a inconstitucionalidade da Resolução do TSE no 23.389/2013, que cuidava desse assunto para as eleições de 2014.

O critério político, conquanto fluído e não inteiramente demarcável de forma

\footnotetext{
${ }^{437}$ Ações julgadas em conjunto, todas de relatoria do Ministro Gilmar Mendes. Todos os acórdãos publicados no DJe 29/10/2014.

${ }^{438}$ DJU de 19/05/95, relator Ministro Octavio Gallotti.
} 
teórica, não pode ser desprezado na análise de um silêncio legislativo, pelo menos em relação a algumas normas. Nessas, o legislador encontra-se num espaço tal de liberdade de atuação que o seu silêncio não pode ser interpretado senão como um modo legítimo, e jurisdicionalmente incontrolável, de fazer política.

\subsubsection{O silêncio legislativo e as normas programáticas}

Situação semelhante à analisada no subitem anterior diz respeito a normas constitucionais que foram introduzidas na Constituição como fórmula utilizada pelo constituinte para possibilitar a votação e aprovação da Constituição, sendo que as discordâncias políticas seriam resolvidas no futuro (relembre-se, para isso, o voto do Ministro Sepúlveda Pertence, no MI n²91). Essas normas são, geralmente, representadas pelas normas programáticas e conferem ao Poder Legislativo ampla margem de liberdade de atuação.

As normas programáticas traduzem-se em linhas diretoras que se acham insertas no sistema jurídico e pelas quais se haverão de orientar os poderes públicos ${ }^{439}$. Por elas, o constituinte regula de modo imediato apenas os comportamentos estatais destinados à obtenção final de efeitos por ele pretendidos, dentro das diretrizes e no sentido nela expresso. "A norma (...) acha-se apta a produzir, imediatamente, apenas fins não essenciais, fins secundários, pois em relação aos essenciais, o legislador constituinte, preferiu ficar em meio do caminho, numa 'promessa de legislação","440.

Não é inoportuno ressaltar que a origem dessas normas remonta à Constituição de Weimar, de 1919, que procurou delinear uma "democracia social". De fato, a segunda parte de seu texto estabeleceu uma série de prestações positivas do Estado na área de educação, saúde, previdência, direito ao trabalho, família (igualdade de direitos entre homens e mulheres e entre filhos legítimos e ilegítimos), limitação à liberdade do mercado, etc. Isso favoreceu "grupos inteiros, e não apenas indivíduos, que passaram a exigir dos Poderes Públicos uma orientação determinada na política de investimentos e de distribuição de bens"

${ }^{439}$ Cf. MIRANDA, Francisco Cavalcanti Pontes de. Comentários à Constituição de 1967. Vol I. Editora Revista dos Tribunais, São Paulo, 1967, p. 127.

${ }^{440}$ Cf. TEIXEIRA, J H Meirelles. Curso de Direito Constitucional, cit. p. 324.

${ }^{441}$ Cf. COMPARATO, Fábio Konder. A afirmação histórica dos direitos humanos. $7^{\mathrm{a}}$ ed. São Paulo : Saraiva, 2010, pp. 196-199. 
São essas disposições que permitem acomodar conflitos e dissensões entre as diversas forças políticas atuantes na sociedade. Por essa razão é que Carl Schmitt as definiu como compromissos dilatórios. Isso porque as normas que os compunham não diziam com uma decisão política fundamental - que, como visto, está na base do conceito de constituição do autor alemão. Significavam uma alternativa a meio termo entre as concepções burguesas e as de índole socialista. Esses compromissos eram considerados por ele como não autênticos: limitavam-se a uma fórmula que satisfizesse todas as exigências contraditórias que marcavam as disputas partidárias ${ }^{442}$. Por isso mesmo, o objetivo neles contido era o de não ter nenhum tipo de decisão nas matérias neles constantes ${ }^{443}$. Logo, não é de se estranhar que o conteúdo programático estabelecido na Constituição jamais lograria a concretizar-se na realidade alemã daquele tempo ${ }^{444}$.

Essa característica das normas programáticas não teria sido alterada nas Constituições advindas depois do calar dos canhões da Segunda Guerra Mundial. Falando da Constituição italiana de 1947, Vezio Crisafulli ensina que esta nasceu da experiência unitária da luta antifascista, pela independência nacional e pela liberdade. Visava à realização da aliança dos grupos mais avançados da burguesia e com os partidos que representavam a massa operária. Refletia, portanto, um ponto de equilíbrio entre as diversas forças políticas e as respectivas tendências programáticas: fossem as que defendiam o restabelecimento do ordenamento jurídico e social à época pré-fascista ou as

\footnotetext{
${ }^{442}$ Cf. SCHMITT, Carl. Teoría de la Constitución, cit, p. 69. Disse ele: "el compromisso no afecta a la solución objetiva de una cuestión por médio de transaciones objetivas, sino que el acuerdo tende a contetarse con una formula dilatória que tenga em cuenta todas las pretensiones". É o que Gustavo Zagrebelsky e Valeria Marcenò chamam de Constituição como instrumentum pacis entre as forças operárias e as capitalistas, que acaba por tornar-se apenas um armistício, dadas as perspectivas incertas (Cf. ZAGREBELSKY, Gustavo; MARCENÒ, Valeria. Giustizia Costituzionale, cit, p. 45).

${ }^{443}$ Cf. BERCOVICI, Gilberto. Entre o Estado Total e o Estado Social. Atualidade no debate sobre direito, Estado e economia na República de Weimar. Tese de Livre-Docência. USP, 2003, p. 17. Segundo o autor, esta era também o entendimento de Otto Kirchheimer: a Constituição de Weimar era uma Constituição sem decisão (op. cit., p. 21).

${ }^{444}$ Além da falta de mecanismos (judiciais ou políticos) que pudessem ser utilizados para alcançar seus objetivos, a Constituição de Weimar foi vítima da efemeridade da própria República homônima. Esta durou apenas quatorze anos e padeceu de severa instabilidade política. Cf. BONAVIDES, Paulo. Curso de Direito Constitucional, cit, pp. 232 e 233; COMPARATO, Fábio Konder. A afirmação histórica dos direitos humanos, cit, pp. 190-192. Conferir Ainda: DIMOULIS, Dimitri; MARTINS, Leonardo. Teoria Geral dos Direitos Fundamentais. São Paulo : Editora Revista dos Tribunais, 2009, p. 29. Tal Constituição não contava sequer com instrumentos voltados à defesa da ordem constitucional democrática (o que possibilitou Hitler chegar ao poder pelas mãos da legalidade). Klaus Stern, ao atribuir o adjetivo "neutro" à democracia de Weimar, sentenciou que "a proteção da Constituição frente a um atentado ao núcleo da Constituição é um problema que todo Estado Constitucional tem que colocar-se. A República de Weimar naufragou como consequência de uma equivocada apreciação da situação assim como falta de medidas a esse respeito (Cf. STERN, Klaus. Derecho del Estado de la Republica Federal Alemana, cit., p. 385).
} 
que lutavam por significativas (por que não dizer, radicais) mudanças naquela sociedade ${ }^{445}$.

É de se perquirir se, no Brasil, as normas programáticas teriam perdido essa característica, mesmo após o advento da Constituição de 1988? Seguramente, não. Ainda que na Comissão Afonso Arinos, responsável pela sugestão de um anteprojeto de Constituição, tivessem prevalecido deliberações de cunho social-democrático e de inspiração marxista, profundamente preocupadas com a estatização da economia, e, na visão de Miguel Reale, marcadamente xenófobas, o resultado daquele projeto buscou uma espécie de acordo ${ }^{446}$.

De fato, dado o processo de redemocratização do país, a própria "Assembleia Constituinte" - entre aspas porque não foi composta com o fim exclusivo de elaborar a Constituição - era um "estuário de tendências políticas diferenciadas e sismógrafos de aspirações populares [e] conduziu uma solução de consenso que se foi cristalizando, entre avanços e recuos, nas fases de sua elaboração"447. E, "na tentativa de firmar o termo médio, aceitável pela maioria, muitas das inovações constitucionais revestiram a forma de preceitos de aplicabilidade diferida"448. Daí a razão pela qual abundam na Constituição de 1988 normas programáticas ${ }^{449}$ e outras promessas, como aquelas presentes no artigo $3^{\circ}$.

\footnotetext{
${ }^{445}$ Cf. CRISAFULLI, Vezio. La costituzione e le sue disposizioni di principio, cit., p. 30. No mesmo sentido, mas em relação às Constituições de 1934 e 1946: TEIXEIRA, J H Meirelles. Curso de Direito Constitucional. Forense universitária, 1991, p. 324.

${ }^{446}$ Cf. REALE, Miguel. Liberdade e Democracia, cit., pp. 3, 6-7, 24-33.

447 Cf. TÁCITO, Caio. Como fazer valer a Constituição? Revista de Direito Administrativo. Rio de Janeiro : Renovar/FGV, no 242, out/dez 2005, pp. 1-7 (especificamente, p. 2).

${ }^{448}$ Cf.TÁCITO, Caio. Como fazer valer a Constituição?, cit, p. 3. Num tom mais crítico (por que não dizer irônico), antes ainda da convocação do poder constituinte, Eros Grau afirma que a Constituição seria, pelos conflitos entre grupos, estamentos e classes sociais, um ato de força, um ato de força da força dominante. Pelo caráter individualista da sociedade, fundada na competição, há sempre a necessidade do conflito para a garantia de sua subsistência. Isso justificaria a afirmação segundo a qual a Constitução é um pacto ou compromisso entre forças sociais, cujo intuito seria a transmutação da luta em jogo. Por que foi dito que foi crítico (se não irônico)? Por que a seu ver, a luta seria algo a ser evitada, pois conduziria a um embate final, culminando com a exterminação do adversário, o que seria perigoso para a própria força dominante. Transforma-se então o Estado em árbitro do jogo, que é jogado conforme normas preestabelecidas. Exemplos disso seriam as normas programáticas: princípios de força jurídica menor, consagradoras de direitos que não são juridicamente garantidos, a não ser que o legislador ordinário atue. Isso seria, na verdade, estratégia para justamente retardar-se a conquista desses direitos pela sociedade, ao mesmo tempo em que promove a pacificação do povo e a sua conformação, para proveito das "ordens privilegiadas". Por conseguinte, a Constituição traduz-se em mito de dominação. (Cf. GRAU, Eros Roberto. A constituinte e a constituição que teremo, cit., pp. 41 e 44-45).

${ }^{449}$ Merece destaque a lição de BASTOS, Celso Ribeiro. Curso de Direito Constitucional. 22a ed. São Paulo : Malheiros editores, 2010, pp. 138-139: “(...). Constata-se que muitas vezes as normas programáticas surgem na Constituição como uma solução de compromisso. De um lado há aqueles que propugnam pela concessão integral e plena de um dado direito. De outro, há os que terminantemente o repelem. Em terceiro lugar, surge a solução compromissória: confere-se o direito com caráter programático e ambos os lados se sentem parcialmente vitoriosos".
} 
É correto afirmar que normas dessa natureza, portanto, caracterizam-se por conferir ao sistema maleabilidade ou adaptabilidade ao sistema jurídico ${ }^{450}$, ao prospetarem efeitos diferidos no tempo.

Por ligarem-se à explicitação de valores, à promessa de justiça social ${ }^{451}$, à realização espiritual ${ }^{452}$, à transformação das estruturas sociais e da realidade constitucional ${ }^{453}$, a questão mais frequente que gira em torno das normas programáticas refere-se ao seu alcance normativo.

Em primeiro lugar, concorde-se que essas normas possuem uma função importante quanto ao confronto político, inevitável numa sociedade aberta, e legitimam as políticas que atendem aos fins nelas dispostos, rechaçando aquelas que não se the adequam. Serão, assim, relevantes para a jurisdição constitucional para afastar as leis que atentem contra os fins nelas expostas, o que acontece nos casos de erro ou de arbítrio manifesto ${ }^{454}$. No entanto, devem deter-se diante da discricionariedade legislativa, porquanto a Constituição, apesar de estabelecer um vínculo finalístico, não predetermina as vias específicas ou os meios para alcança-los ${ }^{455}$. Essas normas, em suma, evocam algo que é determinável só politicamente:

${ }^{450}$ Cf. MIRANDA, Jorge. Manual de Direito Constitucional. cit., p. 274. Assim, também: HORTA, Raul Machado. Estudos de Direito Constitucional, cit., p. 209, que fala em plasticidade, que permite a adaptação da Constituição à realidade social; MOREIRA NETO, Diogo de Figueiredo. Constituição e Revisão. Temas de Direito Político e Constitucional. Rio de Janeiro : Forense, 1991, p. 94, que fala em elasticidade.

${ }^{451}$ Cf. BONAVIDES, Paulo. Curso de Direito Constitucional, cit, p. 245.

${ }^{452}$ Cf. BARROSO, Luis Roberto. O Direito Constitucional e a Efetividade de suas normas. Rio de Janeiro : Renovar, 1995, p. 116.

${ }^{453}$ Cf. MIRANDA, Jorge. Manual de Direito Constitucional. Tomo II, cit, p. 269.

${ }^{454} \mathrm{O}$ que, no Brasil, seria o caso de invalidade da lei por infringência à proporcionalidade.

${ }^{455}$ Cf. ZAGREBELSKY, Gustavo; MARCENÔ, Valeria. Giustizia Costituzionale, cit., pp. 231-233. Eles entendem o mesmo em relação aos princípios, isto é, estes encontram os limites de operacionalidade na "discricionariedade legislativa" (op. cit, p. 230). No mesmo sentido: BARROSO, Luis Roberto. O direito constitucional e a efetividade de suas normas. Renovar, 2009, p. 116, para quem, por essa razão, as normas programáticas não conferem aos cidadãos uma utilidade substancial, fruível positivamente e exigível quando negada. Ver ainda: MELLO, Celso Antônio Bandeira de. Eficácia das normas constitucionais e direitos sociais. Malheiros editores, 2010, pp. 24-25. Esse aspecto especificamente coaduna-se com a seguinte lição de Elival da Silva Ramos: "A categoria teórica da discricionariedade, em qualquer uma de suas vertentes, está fortemente vinculada ao princípio da separação dos Poderes. Importa na contenção do controle jurisdicional em favor do Poder Legislativo ou da Administração, diante da inexistência de limitação normativa ou em face do entendimento de que as normas existentes não autorizam o Poder Judiciário a imposição de determinado padrão de conduta em substituição àquele adotado pelo Poder controlado" (Cf. RAMOS. Elival da Silva. Ativismo judicial. Parâmetros dogmáticos, cit., p. 128). No caso da Constituição brasileira, entretanto, e como se verá abaixo, tomou certas decisões e estabeleceu previamente certos roteiros a serem seguidos pelo legislador, o que diminui a sua liberdade, tolhendo, por conseguinte, possíveis resultados decorrentes do conflito político em si. 
O confronto, o debate político e a assunção de responsabilidade de governo têm exatamente, como aposta em jogo, a decisão sobre o conteúdo de tais conceitos [conceitos sobre "fins sociais", "utilidade social", "função social", etc]. Um liberal e um socialista; um individualista e um 'comunitário' seriam todos de acordo sobre o fato que se deve perseguir 'fins sociais', 'iguais relações sociais', etc, mas a sua concepção é diferente, ou até mesmo oposta ${ }^{456}$.

Na Constituição brasileira, contudo, nem sempre as normas programáticas indicam somente os fins a serem alcançados pelo Estado. Em algumas delas, o constituinte delineou, ainda que de forma não exauriente, o "caminho" que o legislador deve adotar para chegar aos fins que devem ser perseguidos, o que diminuiu sensivelmente a liberdade deste quanto ao trato da matéria ${ }^{457}$. Essa especificidade será abordada de forma mais detalhada mais adiante.

De todo modo, é importante consignar que aquelas primeiras considerações não vão de encontro ao que geralmente a doutrina entende como eficácia das normas programáticas. A propósito, não se nega a natureza jurídica dessas normas. Não há dúvidas em relação a isso. Rui Barbosa, no início do desenvolvimento da moderna teoria constitucional brasileira, dissera-o claramente ${ }^{458}$. No ponto, é acertada a observação segundo a qual, em relação às demais, só existem diferenças de estrutura e projeção no ordenamento, de realização ou de efetividade ${ }^{459}$. Não são normas destituídas de eficácia, mas são de exequibilidade diferida, porquanto apresentam preceito incompleto tanto quanto ao conteúdo de conveniência, quanto o de oportunidade, os quais ficam pendentes de uma dupla definição política: o do como e do quando aplicá-las, gerando uma expectativa de direitos quanto a seus efeitos finais ${ }^{460}$.

\footnotetext{
${ }^{456}$ Cf. ZAGREBELSKY, Gustavo; MARCENÔ, Valeria. Giustizia Costituzionale, cit., p. 232. Traduzido do original: “[i]l confronto, il dibattito politico e l'assunzione di responsabilità di governos hanno per l'appunto, come posta in gioco, la decisione circa il contenuto di tali concetti. Um liberale e un socialista; un individualista e un 'comunitarista' sarebbero tutti d'accordo sul fatto che si debbano perseguire 'fini sociali', 'equi rapporti sociali' ecc., ma la loro concezione è diversa, o addirittura oposta".

${ }^{457}$ Nesse sentido: SILVA, José Afonso da. Aplicabilidade das normas constitucionais. Malheiros, 2012, p. 138; Conferir também: CALLEJÒN, Francisco Balaguer; VILLAR, Gregorio Cámara; AGUILAR, Juan Fernando López; BUESO, Juan Cano; CALLEJÓN, María Luisa Balaguer; RODRÍGUEZ, Ángel. Derecho Constitucional. Madri : Tecnos, 2003, p. 111.

458 "Não há na Constituição, cláusulas, a que se deva atribuir meramente o valor moral de conselhos, avisos ou lições. Todas têm força imperativa de regras, ditadas pela soberania nacional ou popular aos seus órgãos". (BARBOSA, Rui. Commentários á Constituição Federal Brasileira, Vol. II, cit., p. 489). Assim, também, CANOTILHO, J. J. Gomes. Direito Constitucional e Teoria da Constituição, cit., p. 1176: “às 'normas programáticas' é reconhecido hoje um valor jurídico constitucionalmente idêntico ao dos restantes preceitos da Constituiçao".

${ }^{459}$ Cf. MIRANDA, Jorge. Manual de Direito Constitucional. Tomo II, cit, p. 270.

${ }^{460}$ Cf. MOREIRA NETO. Diogo de Figueiredo. Constituição e Revisão..., cit., p. 92. Logo, não é o caso, quer certo autor, de conferir plena aplicabilidade à norma somente pelo fato de nela não se qualificar,
} 
Assim é que, quanto à eficácia, tais normas certamente (a) estabelecem com o legislador uma vinculação, impondo-lhe um dever político ${ }^{461}$; (b) prevalecem sobre normas infraconstitucionais, servindo de parâmetro interpretativo com plena eficácia, no sentido que leis ordinárias que com elas se contradizem estão eivadas de patente inconstitucionalidade ${ }^{462}$, o que acarreta, também, a revogação de normas anteriores que com elas sejam incompatíveis; (c) por indicarem os fins a serem perseguidos, informam a concepção estatal e os valores adotados pela Constituição ${ }^{463}$; d) limitam a discricionariedade da administração e do Poder Judiciário ${ }^{464}$.

Há quem afirme que as normas programáticas podem contribuir para a integração de lacunas, assim como outras normas não exequíveis por si mesmas ${ }^{465}$. Conquanto não se tenha especificado em que medida isso pudesse acontecer, com o devido respeito, não há como compartilhar desse pensamento. Se a norma programática tem efeitos diferidos no tempo, pois depende de atos legislativos e condições financeiras, sociais e políticas apropriadas, isto é se possui fattispecie indeterminada, o efeito delas é justamente o oposto: podem ser muito mais causa de produção de lacunas do que de solução de integração.

Problema mais complexo diz respeito a possíveis direitos subjetivos que as normas programáticas poderiam originar. Afirme-se desde logo que os direitos subjetivos evocáveis perante normas programáticas são de índole negativa, na esteira do que defendem Luis Roberto Barroso e Celso Antônio Bandeira de Mello: (a) oposição ao cumprimento de normas infraconstitucionais contrários ao sentido das normas programáticas e (b) obtenção, nas prestações jurisdicionais, de interpretação e decisão orientadas no mesmo sentido e direção preconizados por estas normas, sempre que estejam em pauta interesses constitucionais protegidos por tais regras ${ }^{466}$. A ressalva a ser feita nessa última hipótese é que o juiz não pode substituir-se ao legislador. Sim, pois na esteira

expressamente, como programática (Cf. BAZÁN, Victor. Hacia la plena exigibilidad de los preceptos constituconales: el control de las omisiones inconstitucionales. Especial referencia a los casos de Brasil y Argentina. In BAZÁN, Victor (coord.). Inconstitucionalidad por omisión. Santa Fé de Bogotá, Colômbia : Editorial Temis, 1997, pp. 49-50).

${ }^{461}$ Cf. DINIZ, Maria Helena. Norma Constitucional e seus efeitos. São Paulo : Saraiva, 1998, p. 116. O problema da vinculação será enfrentado no capítulo seguinte.

${ }^{462}$ No mesmo sentido: BARROSO, Luis Roberto. $O$ direito constitucional e a efetividade de suas normas, cit., p. 117. Vide também: CALLEJÒN, Francisco Balaguer et al. Derecho Constitucional, cit., p. 112

${ }^{463}$ Conferir: CANOTILHO, J. J. Gomes. Direito Constitucional e Teoria da Constituição, cit., p. 1.177.

${ }^{464}$ Efeitos em (a), (c) e (d): Cf. DINIZ, Maria Helena. Norma Constitucional e seus efeitos, cit., p. 116.

${ }^{465}$ Cf. MIRANDA, Jorge. Manual de Direito Constitucional. Tomo II, cit, p. 279.

${ }^{466}$ Cf. BARROSO, Luis Roberto. O direito constitucional e a efetividade de suas norma, cit., pp. 117-118; MELLO, Celso Antônio Bandeira de. Eficácia das normas constitucionais e direitos sociais, cit, p. 25. 
do que restou esclarecido acima, as normas programáticas incutem mais a ideia de expectativa de direito do que relações que possam invocar direitos subjetivos determinados judicialmente.

Como se disse anteriormente, na Constituição brasileira, existem algumas normas programáticas que já possuem densidade suficiente para tornarem-se exequíveis, de modo que podem motivar a declaração de inconstitucionalidade por omissão. Ao acesso ao ensino obrigatório e gratuito, por exemplo, foi reconhecida o status de direito público subjetivo (art. 208, $\S 1^{\circ}$ ). Também seria o caso de direito ao benefício de um salário mínimo, a título de assistência social ao deficiente ou idoso que comprovasse que não possui meios suficientes para prover à própria manutenção ou a de tê-la provida por sua própria família (previsto no art. 203, V). Outros casos seriam o da própria estruturação da seguridade social e do sistema único de saúde, previstos, respectivamente, nos arts. 194 e 200.

Não se olvide que há autores inconformados com os limites eficaciais a que as normas programáticas geralmente se atêm, propõem ir mais além: de quaisquer delas extraírem direitos subjetivos "positivos", isto é, situações de vantagem determinadas ou determináveis judicialmente, mediante a utilização dos mecanismos processuais existentes na Constituição (no caso, a brasileira) concernentes à inconstitucionalidade por omissão ${ }^{467}$.

O que depõe contra essa solução é que eles precisam demonstrar o que já dão por demonstrado: que, salvo casos excepcionais, as normas programáticas possuem condições de exequibilidade imediata, a despeito de necessitarem de "uma terceira instância política, administrativa e material" ${ }^{\text {468 }}$. ${ }^{467}$ Cf. PIOVESAN, Flávia. Proteção judicial contra omissões legislativas. Editora Revista dos Tribunais,
2003 , pp. 80-82; PIOVESAN, Flávia. Constituição e transformação social: a eficácia das normas
constitucionais programáticas e a concretização dos direitos e garantias fundamentais. Revista da
Procuradoria Geral do Estado de São Paulo. Centro de Estudos, n 37 , junho 92, pp. 64-74) e José Afonso
da Silva (SILVA, José Afonso da. Aplicabilidade das normas constitucionais, cit., pp. 150-152).
468 Cf. FERREIRA FILHO, Manoel Gonçalves. Comentários à Constituição de 1988, Vol. I. Saraiva, 2000,
p. 7 . Novamente, faz-se necessária a lição de Celso Ribeiro Bastos. De antemão, escusa-se pela larga citação,
mas afirme-se que é imperiosa para esclarecer o ponto: “(..) Elas [as normas programáticas] almejam,
fundamentalmente, a outorga aos cidadãos de direitos contra o Estado, daí a sua inserção natural nos
capítulos referentes aos direitos fundamentais, tanto os de ordem individual, quanto os de ordem política e
social. Desse fato decorre a sua contradição interna. De um lado, são extremamente generosas quanto às
dimensões do direito que disciplinam, e, por outro, são muito avaras nos efeitos que imediatamente
produzem. A sua gradativa implementação, que é o que no fundo se almeja, fica sempre na dependência de
resolver-se um problema prévio, fundamental: quem é que vai decidir sobre a velocidade dessa
implementação? Pela vagueza do Texto Constitucional, essa questão fica subordinada a uma decisão política.
Trata-se, portanto, de matéria insuficientemente juridicizada. O direito dela cuidou, sim, mas sem evitar que
ficasse aberta uma porta para o critério político. Aliás, é bom que se diga que nem poderia ser de outra
maneira, visto que somente decisões de ordem política estarão em condições de identificar revoluções na 
Logo, de um modo geral mesmo quando as normas programáticas contenham uma reserva de lei, não quer isso dizer que necessariamente haverá um dever de legislar cuja inadimplência seja controlável pela jurisdição constitucional.

No ponto, relembre-se que a Constituição nas democracias contemporâneas é aberta. E isso quer dizer que, conforme a lição transcrita no item 1.3.1, são as gerações vivas, através de seus representantes no Poder Legislativo, que devem se manifestar sobre determinada matéria. Naturalmente, se esse órgão ainda não se manifestou é porque, naquela geração, ainda não houve o consenso sobre o que a matéria a ser legislada deve compreender, ou, em outras palavras, o silêncio legislativo pode indicar que não se completou o "processo de maturação social no tema"469. Se essa lição pode ser adotada em relação a qualquer norma constitucional que demande a atuação legislativa, com muito mais razão o será para as normas programáticas.

\subsubsection{Normas programáticas e políticas públicas}

No constitucionalismo democrático, de inimigo ao desenvolvimento livre das autonomias individuais, o Estado converteu-se no amigo que está obrigado a satisfazer as necessidades coletivas ${ }^{470}$. Assumiu funções antes impensáveis, como regulador, planificador e supervisor da vida socioeconômica, nela intervindo de modo cada vez mais contundente. Tudo isso com lastro constitucional, pela profusão de normas programáticas e pela expansão da própria concepção de direitos fundamentais que passou a abarcar diversos outras prestações. Nessa nova concepção, e especificamente quanto à Constituição brasileira vigente, incluem-se não apenas direitos sociais que ela alberga, mas também outros implícitos decorrentes dos princípios e tratados internacionais de que a República Federativa do Brasil faça parte p71 $^{471}$

Esses novos direitos, essas novas exigências, os novos fins e programas que as Constituições impuseram ao ente estatal provocam uma forte contradição quanto ao modo de se conceber a Constituição. Ao mesmo tempo em que, como se viu, a melhor doutrina patrocina a visão de Constituição como ordem aberta, deixando ao alvedrio das diversas

ordem socioeconômica do Estado que sejam de monta a já ensejar um alargamento dos direitos de cunho social" (Cf. BASTOS, Celso Ribeiro. Curso de Direito Constitucional, cit., pp. 143-144).

${ }^{469}$ Cf. VALLE, Vanice Regina Lirio do. Sindicar a omissão legislativa..., cit., p. 164.

${ }^{470}$ Cf. LOEWENSTEIN, Karl. Teoría de la Constitución, cit., p. 400.

${ }^{471}$ Cf. LEAL, Roger Stiefelmann. Direitos sociais e a vulgarização da noção de direitos fundamentais. $O p$. cit., p. 4. 
correntes políticas a tomada de decisões que são de sua responsabilidade, certas opções do Legislador Constituinte acabam por limitar severamente tal abertura.

De há muito se entende que a norma programática mistura-se a outras normas jurídicas cogentes, de modo que se há de se separar, desde o início, o que é norma jurídica incidente e o que é norma jurídica para ser observada pelas outras regras jurídicas que a formularem na matéria. "Algo do que era político, partidário, programático, entrou no sistema jurídico; cerceou-se, com isso, a atividade dos legisladores futuros, que, no assunto programado, não podem ter outro programa" ${ }^{472}$.

A Constituição brasileira vigente deu, então, "preferência [a] modelos jurídicos cerrados, os quais preordenariam de antemão a sociedade brasileira, num 'holismo' que não deixa espaço para futuras opções, com bloqueio do livre jogo democrático" ${ }^{\text {473 }}$.

O mesmo caminho trilhou Roger Stiefelmann Leal. Comentando sobre o característico acento dirigente da Constituição de 1988, notória influência da Constituição portuguesa de 1976, ressalta, com razão, que o detalhamento de várias políticas públicas (ou seja, os meios a se atingirem os fins do Estado preconizados pela Constituição) não deixa muita margem à discussão política. Partidos que porventura tenham uma linha programática consistente em modos de atuação diferentes dos delineados na Constituição quanto, por exemplo, às áreas de saúde (artigo 198), previdência social (artigo 201), previdência privada (artigo 202), ensino (artigo 205 e ss.), etc. -, uma vez porventura alçados à posição de Governo, não têm condições de implementá-los. "Ou seja, o embate partidário travado, seja em ambiente parlamentar, seja em face de processo eleitoral, enfrenta restrições ideológicas de estatura constitucional" ${ }^{474}$. E se houver possíveis propostas visando à modificação daquelas políticas públicas, tais somente poderão ser veiculadas por Emendas à Constituição.

\footnotetext{
${ }^{472}$ Cf. MIRANDA, Francisco Cavalcanti Pontes de. Comentários à Constituição de 1967. São Paulo : Editora Revista dos Tribunais, 1967, p. 127.

${ }^{473}$ Cf. REALE, Miguel. Liberdade e Democracia, cit., p. 49.

${ }^{474}$ Cf. LEAL. Roger Stiefelmann. Pluralismo, políticas públicas e a Constituição de 1988: considerações sobre a práxis constitucional brasileira 20 anos depois. In: MORAES, Alexandre (coord.). Os 20 anos da Constituição da República Federativa do Brasil. São Paulo : Editora Atlas, 2009, pp. 73-97, mais especificamente, p. 84.
} 
$\mathrm{E}$, de fato, conforme demonstrou o autor, foram produzidas Emendas às ensanchas $^{475}$, ora restringindo, ora tornando ainda mais dirigentes normas constitucionais portadoras de políticas públicas.

As consequências desse "governo por emendas" e não só por leis, foram argutamente por ele evidenciadas: em primeiro lugar, há um agravamento do quórum no Congresso para aprovação de medidas de governo (não mais da maioria, mas de $3 / 5$, porquanto de Emendas se trata), o que, não é difícil concluir, torna a função de governo ainda mais complexa. Além disso, tais Emendas se expõem ao controle de constitucionalidade pelo Judiciário. E isso também provoca seus corolários: torna rotina o que era uma atividade excepcional e estimula a interpretação e aplicação das limitações constitucionais ao poder de reforma (há a contraposição entre a Emenda editada e o artigo 60, da Constituição). Assim, as matérias essencialmente constitucionais, arremata o autor, refugiam-se naquelas limitações, o que estimula a compreensão ampliativa de seus termos $^{476}$.

Essas posições coincidem com o que já pensava Ernst Forsthoff. Ele foi observador crítico de certa jurisprudência do Tribunal Federal Constitucional Alemão que sujeitava o desenvolvimento da "vida constitucional" a conceitos e parâmetros de natureza administrativa. Ele se insurgia particularmente à transposição da proporcionalidade e da discricionariedade ao Direito Constitucional no controle de constitucionalidade de leis que se relacionavam com direitos fundamentais. No primeiro caso, a utilização acrítica da proporcionalidade tornava leis que impunham um dever um ato de obediência facultativa, haja vista que a noção do que é proporcional ou não figurava no campo das subjetividades. Em sua opinião, de consequência, isso dava ao administrador e ao juiz o poder de dispensar a aplicação de uma prescrição normativa imediatamente vinculante. De igual modo, o Tribunal, ao fazer uso do conceito de discricionariedade, acabava por comparar a atividade legislativa à função administrativa, isto é, a de mera regulação.

Essas observações levam, como conclusão, ao inevitável rebaixamento da função legiferante, em claro menosprezo à liberdade do legislador. Tudo isso somado nada mais significava que a conversão da república alemã numa imensa administração, o que

${ }^{475}$ Cf. LEAL, Roger Stiefelmann. Pluralismo, políticas públicas e a Constituição de 1988... . Op. cit, p. 87. Na página indicada do artigo em comento, publicado em 2009, o autor dá conta que, de 1998 a 2008, foram editadas, em média, 3,6 Emendas por ano. Nos dez anos anteriores, a média ficou em 2,5 Emendas por ano. ${ }^{476}$ Cf. LEAL, Roger Stiefelmann. Pluralismo, políticas públicas e a Constituição de 1988... . Op. cit., pp. 9194. 
deveria levar a indagar-se no que se transformaram aqueles representantes do povo que não souberam opor-se à redução do Parlamento a um órgão executivo ${ }^{477}$. Parece claro que semelhantes posições valem também para a Constitução brasileira.

Não é o objetivo deste trabalho analisar, de forma exauriente, a questão da justiciabilidade das normas programáticas. O recorte a ser feito dar-se-á quanto à apuração de eventual dever de legislar que gere uma omissão inconstitucional.

Nesse aspecto, é certo considerar que o legislador tem o dever de atendê-las. É inaceitável que deixe normas constitucionais, ainda que programáticas, fora do máximo alcance eficacial. Mas, geralmente, trata-se de um dever geral, e não específico. Mas que disso leve a que o Tribunal lhe dirija uma determinação de legislar ou, persistindo a omissão, crie a norma, em sede de mandado de injunção, é cientificamente duvidoso ${ }^{478}$. Isso porque, se não há parâmetros exatos para se definir o conteúdo de um direito social, o que induz à conclusão de que trata-se de questão muito mais de índole política que jurídica $^{479}$, a definição do momento da ocorrência da omissão legislativa inconstitucional também é enigmática. Se assim é, isso leva a questionar quando o Tribunal pode concluir que o legislador estaria apto a emitir a legislação omissa para aqueles casos de prestação positiva? Pela passagem do tempo, afinal a Constitução já está prestes a tornar-se balzaquiana? Nesse caso, caberia então ao Estado comprovar que não tem condições de atuar ou que, pelo menos, cumpriu o mínimo existencial ou que não está procedendo a um retrocesso, como defendem alguns?

Nada obstante, em termos de normação insuficiente, não se exclui a declaração de inconstitucionalidade por omissão, tendo em vista, inclusive, o disposto no artigo 12-F, $\S 1^{\circ}$, da lei no $9.868 / 99$ (ainda que, muitas vezes, a solução dada por essa lei não seja a melhor do ponto de vista lógico). O problema parece ser mesmo a falta de instrumental normativo sobre determinada norma constitucional.

No mesmo sentido, tendo em vista que aquele diploma legal criou uma espécie de "dilação probatória", pelo teor dos artigos $7^{\circ}, \S 2^{\circ}$ e $9^{\circ}, \S 1^{\circ}$, da lei supracitada, o que, somado ao caráter analítico da Constituição também em matéria de políticas públicas, seria possível, pelo menos em tese, a declaração de omissão inconstitucional tendo como

\footnotetext{
${ }^{477}$ Cf. FORSTHOFF, Ernst. Lo stato della società industriale, cit., pp. 154-160.

${ }^{478}$ Entretanto, essa não é a posição do STF, que desde o MIQO n ${ }^{\circ} 107$ entende que o writ, pelo menos em tese, é aplicável para todo e qualquer direito social.

${ }^{479}$ Cf. LEAL, Roger Stiefelmann. Direitos sociais e a vulgarização da noção de direitos fundamentais. $O p$. cit., passim.
} 
parâmetro normas programáticas, ainda que isso seja procedimento de todo criticável, conforme se expôs acima.

A par dos exemplos já citados acima, em termos de direito à saúde, portanto, se a lei complementar $n^{\circ}$ 141/12 não houvesse sido editada, poder-se-ia extrair um dever específico de legislar quanto à necessidade de se definir os percentuais de aplicação dos recursos a que faz menção o artigo $198, \S 2^{\circ}$, como preconiza o $\S 3^{\circ}$ do mesmo dispositivo. $\mathrm{Ou}$, em relação ao direito à educação, a Corte poderia julgar inconstitucional o silêncio legislativo porventura evidenciado quanto ao artigo 208, por exemplo.

A propósito, é interessante notar que, no julgamento da ADI $\mathrm{n}^{\circ} 1.698^{480}$, os ministros do STF ventilaram a possibilidade de controlar não somente a omissão legislativa decorrente do não atendimento a normas programáticas, mas também a falta de políticas públicas ou, mais grave ainda, políticas públicas que viessem a ser consideradas insuficientes. Com efeito, o que chama a atenção nesse julgado é que, conquanto ação tenha sido julgada improcedente, isto é, pela rejeição da declaração de inconstitucionalidade por omissão, mais do que a análise sobre a existência ou não de lei, ou pela suficiência ou insuficiência desta, o Tribunal enveredou para a discussão sobre a suficiência ou não das políticas públicas elaboradas pelo governo a partir das leis existentes.

O parâmetro seria, então, não o disposto na lei, mas o resultado da aplicação dela, o que poderia motivar a omissão inconstitucional parcial. Claramente o controle das políticas públicas foi aventado como parâmetro para a declaração de omissão inconstitucional, o que, a priori vai de encontro ao disposto na ADI $\mathrm{n}^{\circ} 19$ (como mesmo reconheceu a relatora), quando se marcou posição no sentido de que a omissão a ser evidenciada dá-se no campo normativo, e não no caso concreto. O Ministro Marco Aurélio chegou a considerar que o mínimo de investimento previsto na Constituição não era o bastante. Posições desta natureza, se prevalecentes, conferem ao artigo 103, §2 ${ }^{\circ}$, da Constituição Federal uma amplitude maior de aferição da omissão legislativa. Bastaria considerar o não atendimento do dispositivo constitucional do ponto de vista substancial, isto é, pelo oferecimento incompleto das prestações previstas pelo dispositivo constitucional para que o Tribunal declarasse a infringência da Constituição.

${ }^{480}$ DJe de 15/04/2010, relatora Ministra Cármen Lúcia. 
Pode-se ainda dar como exemplo desse tipo de atuação jurisdicional o decidido na Rcl. $\mathrm{n}^{\mathrm{o}} 4.374^{481}$. Neste caso, o Tribunal (re)analisou a constitucionalidade no artigo 20, $\S 3^{\circ}$, da lei 8.742/93, que instituiu o benefício de um salário mínimo a idosos e deficientes físicos que pertencessem a família cuja renda mensal per capita fosse inferior a $1 / 4 \mathrm{de}$ salário mínimo, concretizando, pois, o artigo 203, V, da Constituição Federal. Trata-se de reanálise porquanto esse preceito já havia sido julgado constitucional pela ADI $\mathrm{n}^{\mathbf{o}}$ 1.232/DF. Concluiu a Corte, com base no voto do relator, o Ministro Gilmar Mendes, que, devido à passagem do tempo e à criação de prestações pecuniárias de outras naturezas, como Bolsa Família (lei no 10.836/04), Bolsa Escola (lei nº 10.219/01), Programa Nacional de Acesso à Alimentação (lei no 10.689/03) e a autorização ao Poder Executivo para conceder apoio financeiro a municípios que instituírem programas de garantia de renda mínima associados a ações socioeducativas (lei $n^{\circ}$ 9.533/97), a exigência objetiva do dispositivo (renda familiar per capita inferior a $1 / 4$ de salário mínimo) não poderia ser a única a ser levada em consideração para a concessão do benefício. O legislador deveria atentar-se às mudanças da realidade fática para que a ela fosse adequada a redação do preceito supracitado.

$\mathrm{O}$ arremate do julgamento se deu pelo reconhecimento de uma omissão inconstituciona parcial do dispositivo em comento, fundamentada na proibição de proteção insuficiente, pois o critério estabelecido pelo dispositivo, na opinião da Corte, não protege de modo satisfatório do direito previsto no artigo 203, V, da Constituição Federal.

Esse julgado desperta uma série de questionamentos que vão além do controle de políticas públicas. Saber qual o critério utilizado para descobrir-se quão insuficiente é uma proteção é um deles. E, com isso, a possibilidade de atuação da jurisdição constitucional em relação às escolhas políticas feitas por ele.

Hialino está que isso significa interferir indevidamente em eventuais conflitos políticos que a Constituição permite que aconteçam, transformando o Tribunal no legislador-administrador ${ }^{482}$.

${ }^{481}$ DJe de 04/09/2013, relator Ministro Gilmar Mendes. Como precedentes, citem-se também os RE ${ }^{\circ}$ 567.985/MT (DJe 18/04/2013, relator Ministro Marco Aurélio) e RE no 580.963/PR (DJe de 18/04/3013, relator Ministro Gilmar Mendes).

${ }^{482}$ Para uma crítica a esse modo de proceder, tanto da doutrina, quanto da jurisprudência, conferir: LEAL. Roger Stiefelmann. Direitos sociais e a vulgarização da noção de direitos fundamentais. Op. cit., p. 4. 


\subsection{Considerações sobre os critérios apresentados}

Inicialmente, cumpre reconhecer que os parâmetros oferecidos para a separação de omissões legislativas constitucionalmente toleráveis das omissões inconstitucionais, a partir do prazo certo e da reserva de lei imperativa, analisados acima, podem não ser considerados como categorias estanques, definitivas ou que sempre serão de aplicabilidade infalível. Trata-se, em verdade, de propostas de uma sistematização teórica das omissões legislativas, que buscam combinar a liberdade do legislador com sua vinculação positiva com a Constituição aberta.

Aliás, questione-se até que ponto a Constituição brasileira realmente quis obrigar o legislador a legislar, porquanto em diversas matérias ela já deu a solução para a falta de lei, ainda que provisória. Os exemplos foram dados já na Introdução deste estudo, e outros mais podem ser extraídos do texto fundamental. Se ela escolheu algumas matérias para dar um tratamento normativo enquanto a lei necessária para isso não é editada, isto é, matérias que poderiam ser tidas como realmente imprescindíveis para a estruturação do Estado e para a conformação social, a indagação que fica é se, mesmo tendo previsto instrumentos processuais para o reconhecimento da omissão que a vulnera, não teria ela conferido ampla liberdade ao legislador para tratar das demais disciplinas, sem que isso importasse necessária interferência jurisdicional?

Voltando aos parâmetros propostos, que tomaram essa indagação em consideração e restringem as hipóteses de dever específico de legislar, é verdade, não se nega que não estejam a salvo de severas objeções, ainda mais em se partirem de certa doutrina que às vezes confunde o princípio da máxima efetividade da Constituição com efetividade a qualquer preço ${ }^{483}$.

Especialmente em relação à reserva de lei, pelo que foi analisado, é natural que se conclua que a norma que a contenha converta-se em fonte de um dever específico de legislar, cuja inobservância pode caracterizar uma inconstitucionalidade por omissão. Todavia, excluídos os casos de reserva de lei dispositiva e também as diferenças terminológicas utilizadas pelo próprio texto constitucional, pode acontecer também que a jurisdição constitucional entenda que não há um dever de legislar nem mesmo diante de uma reserva de lei imperativa.

${ }^{483}$ Ver item 2.4.1. 
Foi o que aconteceu quando o Tribunal negou a concessão de mandado de injunção referente ao fundo de garantia de execução trabalhista, por entender que a falta desse fundo não interferira na percepção dos direitos trabalhistas do impetrante, cujo não pagamento se dera apenas em função da inadimplência da empresa condenada (recente decisão no $\mathrm{MI} \mathrm{n}^{\circ}$ 6.052/BA ${ }^{484}$ ). Isto é, o impetrante teria tido outros meios para fazer valer seu direito ao crédito trabalhista. Isso motivou a utilização de fundamento já tradicional nesse tipo de writ: o de que o dever de legislar deve ser confrontado com um direito subjetivo do impetrante, que não pode ser exercido por ausência de norma.

É oportuno ressaltar, contudo, que o art. $3^{\circ}$ da Emenda Constitucional $n^{\circ}$ 45/2004, preconiza expressamente que "lei criará o Fundo de Garantia das Execuções Trabalhistas...”. O dado peculiar desse caso é que a razão de ser desse Fundo é a de servir como garantia do juízo da execução trabalhista e, portanto, da efetividade da própria sentença exarada pela justiça trabalhista, justamente quando o empregador for insolvente ${ }^{485}$.

Conquanto não tenha sido analisada a questão especificamente em função da reserva de lei, mas tão-somente em relação à contraposição entre direito subjetivo e dever de legislar, de todo modo o Tribunal afastou a alegação de mora legislativa.

Ressalte-se que, em termos dogmáticos, decisões desse jaez não contribuem para a formulação teórico-científica de um conceito de omissão inconstitucional baseado num dever de legislar ${ }^{486}$. Servem, contudo, para mostrar que nem sempre ocorre a correspondência automática entre norma preceptiva não exequível por si mesma e uma omissão inconstitucional. Ademais, reforçam a impressão de que o reconhecimento desse tipo de inconstitucionalidade ainda está ainda associado a uma boa dose de casuísmo.

Em termos de reserva de lei, com efeito, foi declarada a inconstitucionalidade por omissão (total ou parcial) pelo silêncio legislativo em função do não atendimento aos

\footnotetext{
${ }^{484}$ DJe divulgado em 27/05/2014. Essa decisão monocrática foi confirmada em sede de Agravo Regimental, cujo acórdão foi divulgado pelo DJe de 18/08/2014.

${ }^{485}$ Nesse sentido: COSTA, Carolina Popoff Ferreira da. Fundo de Garantia das Execuções Trabalhistas. Dissertação de mestrado. USP, 2011, conclusões.

${ }^{486} \mathrm{Em}$ termos de controle abstrato da omissão legislativa, dada a proximidade das conclusões em relação à reserva de lei, é útil transcrever a lição de VALLE, Vanice Regina Lírio. Sindicar a omissão legislativa, cit. 181: “o processo de construção teórica da Corte (...) se deu por agregação, provocado pelos termos das demandas que se punham, sem uma sistematização prévia que se pudesse beneficiar pela não subordinação das circunstâncias da situação concreta. Mais ainda; cada qual das premissas estabelecidas nos precedentes se tinha, novamente, por inafastáveis, sem que a Corte se permitisse uma revisão construtiva dos termos dos pronunciamentos já lançados. Não se pode extrair, portanto, da elaboração casuística da Corte Constitucional, uma construção sistêmica, seja dos contornos do instituto em si; seja de seu potencial de contribuição ao propósito de máxima efetividade da Carta de Outubro".
} 
seguintes preceitos: arts. $18, \S^{\circ}$ (“a criação, a incorporação, a fusão e o desmembramento de Municípios, far-se-ão por lei estadual, dentro do período determinado por Lei Complementar Federal, e dependerão de consulta prévia, mediante plebiscito, às populações dos Municípios envolvidos, após divulgação dos Estudos de Viabilidade Municipal, apresentados e publicados na forma da lei”, na redação dada pela EC $\mathrm{n}^{\mathbf{o}}$ $15 / 96)^{487} ; 37, \mathrm{X}$ (“a remuneração dos servidores públicos e o subsídio de que trata o $\S 4^{\text {o }}$ do art. 39 somente poderão ser fixados ou alterados por lei específica, observada a iniciativa privativa em cada caso, assegurada revisão geral anual, sempre na mesma data e sem distinção de índices", na redação dada pela EC 19/98) ${ }^{488}$; 45, §1 ("a Câmara dos Deputados compõe-se de representantes do povo, eleitos, pelo sistema proporcional, em cada Estado, em cada Território e no Distrito Federal. $\S 1^{\circ} \mathrm{O}$ número total de Deputados, bem como a representação por Estado e pelo Distrito Federal, será estabelecido por lei complementar, proporcionalmente à população, procedendo-se aos ajustes necessários, no ano anterior às eleições, para que nenhuma daquelas unidades da Federação tenha menos de oito ou mais de setenta Deputados) ${ }^{489}$; 161, II ("Cabe à lei complementar: II estabelecer normas sobre a entrega dos recursos de que trata o art. 159, especialmente sobre os critérios de rateio dos fundos previstos em seu inciso I, objetivando promover o equilíbrio sócio-econômico entre Estados e entre Municípios") ${ }^{490}$; 23, caput e parágrafo único dos $\mathrm{ADCT}^{491}$. Bem de ver que cada um desses artigos faz a remissão ao legislador de um modo diferente.

Entretanto, considera-se que isso não diminui a importância da reserva de lei para a aferição de um dever específico de legislar. Julga-se que a importância do oferecimento de novos parâmetros para a aferição de uma inconstitucionalidade por omissão a partir do silêncio do legislativo é, em primeiro lugar, - e se é autorizado a essa

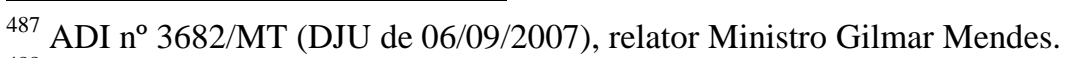

${ }^{488}$ Nas ADIs no ${ }^{\circ}$ 2.061/DF (DJU de 29/06/2001), 2.481/RS (DJU de 22/03/2002) 2.486/RJ (DJU de 19/12/2001), 2.490/PE (DJU de 19/12/2001), 2.492/SP (DJU de 22/03/2002), 2.518/RO (DJU de 19/12/2001), 2.520/PI (DJU de 19/02/2001), 2.524/TO (DJU de 15/03/2002), 2.525/DF (DJU de 05/04/2002), todas de relatoria do Ministro Ilmar Galvão, dentre outras.

${ }^{489} \mathrm{ADI} \mathrm{n}^{\circ}$ 4.947/DF, 4.963/DF, 4.965/DF, 5.020/DF e 5.028/DF (DJe de 29/10/2014, julgadas em conjunto), relator Ministro Gilmar Mendes. E ainda: ADI 5130/DF (DJe 29/10/2014), relator Ministro Gilmar Mendes.

${ }^{490}$ ADI 23/DF (decisão monocrática do relator, Ministro Dias Toffoli, DJe de 31/01/2013). A omissão foi causada pelo vácuo legislativo provocado pelas ADIs $\mathrm{n}^{\circ} 875,1.987,2.727$ e 3.243, que declararm inconstitucionais alguns preceitos da lei complementar $n^{\circ} 62 / 89$, que dava aplicação à norma constitucional em comento. À época do julgamento dessas ações, que se deu em conjunto (DJe de 29/04/2010), o Tribunal havia "prorrogado" a validade da lei por mais vinte e quatro meses, até que outra fosse editada, o que aconteceu somente em 17 de julho de 2013, pela lei complementar n $^{\circ} 143$.

${ }^{491}$ ADI no $^{\circ}$ 889/DF (DJU de 22/04/94), relator Ministro Marco Aurélio.
} 
altura lançar mão de uma ironia - preencher uma lacuna teórica encontrada na doutrina nacional.

E, se tal proposta tem outra utilidade, é a de demonstrar (como demonstrado acredita-se que esteja) que nem todas as normas preceptivas não exequíveis por si mesmas ou normas não preceptivas (como são as programáticas) motivam uma inconstitucionalidade por omissão, pelo menos não sem ulteriores desenvolvimentos teóricos. Logo, a intenção desse capítulo, e por que não dizê-lo, a do próprio trabalho, ainda que seja encarado como uma provocação científica (mas uma provocação científica séria, porque grave é o tema), é iniciar uma discussão teórica sobre esse assunto.

\subsection{Outros critérios utilizados pela doutrina e jurisprudência a partir de lei existente}

Finalmente, como parte final do trabalho, entende-se que não é inoportuno tecer algumas observações sobre alguns deveres de legislar que são justificados pela doutrina e pela jurisprudência a partir de lei já produzida.

Sabe-se que os deveres específicos de legislar, estes consubstanciados em "imposições constitucionais e ordens de legislar"492, "mandatos constitucionais" 493 ou “encargos ao legislador" ${ }^{494}$, são definidos diretamente pela Constituição.

Segundo a doutrina e jurisprudência estrangeiras, sobretudo a alemã, outros, entretanto, decorrem do exercício de hermenêutica constitucional ${ }^{495}$. Estes deveres são

\footnotetext{
492 Cf. CANOTILHO, J. J. Gomes. A Constituição Dirigente..., cit, pp. 297-298. Ao tratar do problema das imposições constitucionais, sustenta que há verdadeiras ordens constitucionais dirigidas ao legislador no sentido de este emitir uma ou várias leis necessárias: (1) à conformação jurídica de situações de fato; (2) à regulamentação de questões específicas; (3) à criação de pressupostos necessários para nova evolução do regime constitucional; e (4) à adaptação das leis antigas aos novos princípios da Constituição. Esses tipos de imposições constitucionais são caracterizados por não serem direitos self-executing, necessitando, pois de lei no sentido de transformarem-se em direito fruível.

${ }^{493}$ A utilização dessa expressão abunda na doutrina e nas Cortes Constitucionais estrangeiras. Sem a pretensão de esgotar toda a doutrina, à guisa de exemplos, além dos já citados acima, podem ser mencionados STERN, KLAUS. Derecho del Estado de la Republica Federal Alemana, cit, p. 225; LLORENTE, Rubio Francisco. La forma del Poder (estudios sobre la Constitución). Madri : Centro de Estudios Constitucionales, 1993, p. 95; OBERNDORFER, Peter; WAGNER, Britta. Legislative omission as a problem of Constitutional Review. In AUSTRIA. Austrian Constitutional Court. Report of the Austrian Constitutional Court. XIV Congress of the Conference of European Constitutional Courts. Vilnius, Lituânia, 2-7 junho 2008. Disponível em www.confeuconstco.org/rep-xiv/report_Austria_en.pdf. Acesso em 15/10/2013, às 20:00h.

${ }^{494}$ Cf. RODRIGUEZ, Jose Julio Fernandez. La inconstitucionalidad por omisión..., cit., p. 86 e ss; PAGÉS, Juan Luis Requejo. Constitución y remisión normativa..., cit. p. 140; SEGADO, Francisco Fernández, El control de constitucionalidad de las omisiones legislativa..., cit., p. 34.

${ }^{495}$ E aqui é clara a influência da doutrina e da jurisprudência constitucional alemãs, como pode ser visto em
} MENDES, Gilmar Ferreira; COELHO, Inocêncio Mártires; BRANCO, Paulo Gustavo Gonet. Curso de 
considerados implícitos, e aqui as hipóteses de obrigação de legislar se expandem para além das remissões feitas concretamente pela norma constitucional.

Portanto, além da falta de concretização de normas constitucionais não exequíveis por si mesmas, uma omissão inconstitucional pode surgir (a) pela falta de proteção dos direitos fundamentais; (b) pela falta de adequação das leis vigentes; e (c) pela omissão na reposição da igualdade ${ }^{496}$. A seguir, serão analisados, ainda que sem a pretensão de exaurimento do tema, cada um deles.

\subsubsection{O dever de proteção dos direitos fundamentais}

O dever de legislar voltado à proteção dos direitos fundamentais comporta alguns desdobramentos. Vai além da obrigação de efetivamente conformar o direito (principalmente os direitos sociais). Consiste igualmente no de proibir condutas ou ingerências, tanto do poder público quanto de particulares (neste caso, em atenção à dimensão horizontal dos direitos fundamentais), que venham a prejudicar direitos alheios. Identifica-se, em suma, com o estabelecimento de restrições à atuação do Poder Público ou a criminalização de condutas que atentem contra bens jurídicos reputados essenciais pela Constituição (liberdade, vida, propriedade, saúde etc.) ${ }^{497}$. Para isso, não importa se esses direitos dependam ou não de posteriores prestações materiais pelo Estado ${ }^{498}$. Trata-se de não impedir certas situações, não intervir em situações jurídico-subjetivas e não eliminar posições jurídicas $^{499}$.

O dever de proteção demandaria, ademais, a criação de garantias institucionais que dessem acesso a determinados bens jurídicos. Cuidar-se-ia de um "direito à organização" ${ }^{500}$. Ou seja, uma dimensão "procedimental-processual-organizatória" voltada

Direito Constitucional. São Paulo : Saraiva, 2010, p. 1131; SILVA, Jorge Pereira da. Dever de legislar e protecção jurisdicional contra omissões legislativas..., cit, p. 21.

${ }^{496}$ Esse apanhado de obrigações está presente na obra de Jorge Pereira da Silva. Confira-se em SILVA, Jorge Pereira da. Dever de legislar e protecção jurisdicional contra omissões legislativas..., cit., pp. 24-88.

497 Sobre a posição do Tribunal Constitucional alemão sobre esses deveres a cargo do legislador, conferir: MENDES, Gilmar Ferreira. Direitos Fundamentais. In Direitos fundamentais e controle de constitucionalidade. Estudos de direito constitucional, cit., p. 12.

${ }^{498}$ Cf. SILVA, Jorge Pereira da. Dever de legislar e protecção jurisdicional contra omissões legislativas, cit., p. 40.

${ }^{499}$ Cf. CANOTILHO, J. J Gomes. Direito Constitucional e Teoria da Constituição, p. 408; ALEXY, Robert. Teoria dos direitos fundamentais. $2^{\mathrm{a}}$ ed. São Paulo : Malheiros editores, 2011, p. 196 e ss.

${ }^{500}$ Cf. PUENTE, Marcos Gómez. La inactividad del legislador: una realidad susceptible de control, cit., p. 72. No entanto, esse "direito à organização", segundo esse autor, não se confundiria com o direito a um serviço público. 
aos direitos fundamentais ${ }^{501}$. Isso é justificável, “ou porque haja de assegurar a intervenção dos cidadãos ou de grupos de cidadãos em decisões colectivas ou porque haja de ser garantida a defesa de outros direitos contra eventuais resultados desfavoráveis a que o procedimento possa conduzir" ${ }^{, 502}$.

Sobre esse dever de proteção, Robert Alexy estatui que pode ser categorizado em quatro classes distintas, sucintamente, a saber: a) dever de formulação de normas legais constitutivas de institutos de direito privado, de modo a propiciar a fruição de direitos, tal como o casamento e a propriedade; b) dever de emanação de normas processuais e procedimentais aptas a garantir uma proteção jurídica efetiva, o que implica garantir a correção e justiça de decisões, mas colocar à disposição do interessado instrumentos efetivos de proteção; c) deveres de criação de normas organizatórias conformes aos direitos fundamentais; d) dever de emanação de normas legais que possibilitem ao cidadão a participação na formação da vontade estatal ${ }^{503}$.

Seriam exemplos disso o direito ao sufrágio, o estabelecimento de procedimentos judiciais céleres; especificação dos processos em que a presença do advogado é obrigatória; proteção dos dados pessoais; garantia do direito de resposta; proteção aos sindicatos; o direito à greve, etc ${ }^{504}$.

O problema do dever de proteção é que, normalmente, a Constituição não oferece nenhum parâmetro de atuação do legislador. Na maioria das vezes, há uma pluralidade de soluções utilizáveis por ele. Há autores para os quais isso parece importar pouco, haja vista que estar-se-á diante de uma omissão inconstitucional quando o legislador não atuar de modo algum (mesmo que haja uma ou várias possibilidades),

\footnotetext{
${ }^{501}$ Cf. SILVA, Jorge Pereira da. Dever de legislar e protecção jurisdicional contra omissões legislativas, cit., p. 52.

${ }^{502}$ Cf. MIRANDA, Jorge. Manual de Direito Constitucional. Direitos Fundamentais. Tomo IV. Coimbra : Coimbra editora, 2000, p. 94.

${ }^{503}$ Cf. ALEXY, Robert. Teoria dos direitos fundamentais, cit., pp. 452 e ss.

${ }^{504}$ Cf. MIRANDA, Jorge. Manual de Direito Constitucional. Direitos Fundamentais. Tomo IV. Coimbra : Coimbra editora, 2000, pp. 75-76 e 96. Marcos Gómez Puente, em passagem obscura de sua obra, sustenta que caberá à jurisdição constitucional estabelecer quais sejam as instituições necessárias para o gozo dos direitos e seus traços principais, pois é a ela que é atribuída a defesa da normatividade da Constituição e que é quem defende o conteúdo essencial de cada direito e as garantias institucionais desses, ante as ações ou omissões do poder público. Curiosamente, ele afirma que o Tribunal amparar esse direito à organização, pois não poderá suprir ou ordenar uma atividade legal ou administrativa que o satisfaça, devendo limitar-se à estipulação de uma indenização em favor daquele que foi prejudicado no exercício de seu direito (Cf. PUENTE, Marcos Gómez. La inactividad del legislador: una realidad susceptible de control, cit., p. 73).
} 
deixando vulnerável o direito, ou se a solução encontrada não for suficiente ${ }^{505}$, posição essa criticável, pois pode resultar em usurpação da atividade legislativa.

\subsubsection{O dever de adequação de leis vigentes}

O dever de adequação das leis vigentes implica considerar que não basta somente o legislador emanar a lei. A ideia subjacente a esse dever é que a Constituição será concretizada somente se o legislador atuar de forma concreta e permanente. Para o atendimento a essas imposições, não é suficiente uma atuação legislativa única, perfeita e acabada. O arcabouço legislativo exigido é amplo, demandando revisão periódica ${ }^{506}$. É preciso que ele acompanhe as mudanças pelas quais naturalmente passa a sociedade e, assim, mantenha as leis sempre atualizadas.

Esse dever é resultado do desenvolvimento jurisprudencial do Tribunal Constitucional Federal alemão em testar a suficiência de leis existentes que versam sobre direitos. Isso ocorre mediante a utilização de técnicas decisórias, como o apelo ao legislador (Appellentscheidung) ou a declaração de inconstitucionalidade sem a pronúncia de nulidade, dos quais já se faltou acima ${ }^{507}$. Destacam-se os casos em que reputa a lei “ainda constitucional", mas encaminhando-se para um quadro de inconstitucionalidade (daí denominar-se de inconstitucionalidade deslizante ou situações constitucionais imperfeitas ou em trânsito para a inconstitucionalidade). O dever de legislar concatena-se, então, com o problema da estagnação da lei no tempo, de modo a evitar que situações que, pela alteração da realidade, permaneçam à margem da norma jurídica ${ }^{508}$.

Diz a doutrina que essa alteração do status constitucional para inconstitucional pode acontecer por razões fáticas ou jurídicas. Seria exemplo de alterações fáticas analisadas pelo Tribunal Constitucional a desfiguração de circunscrições eleitorais por modificações demográficas ocorridas em anos anteriores. Nesse caso, o Tribunal

\footnotetext{
${ }^{505}$ Cf. SILVA, Jorge Pereira da. Dever de legislar e protecção jurisdicional contra omissões legislativas, cit., p. 45.

${ }^{506}$ São as "imposições constitucionais legiferantes em sentido estrito", de CANOTILHO, J .J. Gomes. Direito Constitucional e Teoria da Constituição, cit, p. 1.035. Em sentido semelhante: SILVA, Jorge Pereira da. Dever de legislar e protecção jurisdicional contra omissões legislativas..., cit., p. 33.

507 Cf. MENDES, Gilmar Ferreira. Direitos fundamentais e controle de constitucionalidade. São Paulo : Saraiva, 2006, p. 396 e ss.

${ }^{508}$ Cf. SILVA, Jorge Pereira da. Dever de legislar e protecção jurisdicional contra omissões legislativas..., cit., pp. 59-60.
} 
determinou que o legislador corrigisse as distorções verificadas nas circunscrições eleitorais, antes dos próximos pleitos eleitorais ${ }^{509}$.

Há situações, porém, em que essas razões encontram-se indissociadas. É o caso da pensão previdenciária por morte do cônjuge do sexo feminino. Decidiu o Tribunal que era constitucional a lei que limitava o pagamento de pensão ao cônjuge da falecida segurada apenas se se demontrasse que os rendimentos desta eram fundamentais para o sustento da família. No caso da mulher do segurado, não havia tal limitação. O Tribunal julgou pela constitucionalidade porque as mulheres casadas entre a população economicamente ativa era reduzida. Em decisão posterior (de 1974), o Tribunal, ainda considerando constitucional a referida lei, exortou o legislador a promulgar uma nova, pois, tendo em vista a alteração da quantidade de mulheres casadas economicamente ativas, a lei estava "em processo de inconstitucionalização" 510 .

Comporia esse grupo a polêmica obrigação de corrigir os erros de prognose legislativa, concebidos como equívocos de avaliação no que toca à previsão de fatos futuros $^{511}$. Sustenta-se que, quando essa situação ocorre, o legislador teria o dever de retificar (ou mesmo revogar) leis que restringem de forma indevida (ou desproporcional) um direito fundamental ou que os tutelem de modo insuficiente, "tendo em conta a natureza das posições jurídicas fundamentais ameaçadas e a intensidade do perigo de lesão dessas posições" ${ }^{\text {512. }}$.

Quem defende semelhante obrigação argumenta que é pela passagem de um período razoável de tempo de vigência da lei é que poderão ser verificadas "eventuais consequências invalidantes" desse diploma legal ${ }^{513}$. A dúvida dá-se quanto à possibilidade de se efetuar o controle dessas prognoses pela jurisdição constitucional, haja vista a dificuldade de estabelecer o objeto a ser controlado. Não se olvide, também, as dificuldades de se aceitar a substituição do legislador pela jurisdição constitucional em relação ao estabelecimento de parâmetros para aferição das prognoses "corretas" "514.

\footnotetext{
${ }^{509}$ Cf. MENDES, Gilmar Ferreira. Direitos fundamentais e controle de constitucionalidade, cit., p. 407 e ss. Será analisada situação semelhante ocorrida no Brasil, mais à frente.

${ }^{510}$ Cf. MENDES, Gilmar Ferreira. Direitos fundamentais e controle de constitucionalidade, pp.407-410.

${ }^{511}$ Isso não seria confundível com o erro de diagnóstico, que se dá na hipótese de o legislador avaliar mal a realidade que pretendia normatizar.

${ }^{512}$ Cf. SILVA, Jorge Pereira da. Dever de legislar e protecção jurisdicional contra omissões legislativas... cit., p. 63.

${ }^{513}$ Cf. SILVA, Jorge Pereira da. Dever de legislar e protecção jurisdicional contra omissões legislativas..., cit., p. 64.

${ }^{514}$ No ponto, releva trazer a lume a lição STARCK, Christian. La legitimación de la justicia constitucional y el princípio democrático. Anuario ibero-americano de justicia constitucional. Madri : Centro de Estudios
} 
Parece claro que, se o controle de prognoses é de fato possível, nada impedirá que os Tribunais Constitucionais tencionem a controlar a utilização de critério políticos do processo legislativo, no intuito de se certificar se estudos técnicos, consultas ou audiências públicas, etc. foram efetuados e que os prognósticos dali extraídos são realmente "proporcionais". Assim, e em todo caso, se não for o caso de autocontenção, seria talvez o de serem estipulados limites ${ }^{515}$.

J. J. Gomes Canotilho, por exemplo, compreende que só se pode efetuar controle sobre prognoses legislativas quando a lei utilizar conceitos jurídicos indeterminados e se as prognoses inciderem sobre fatos atuais (o que, na verdade, não se trata mais de prognose, mas de diagnóstico). Assim, as prognoses não podem ser controladas diante de incertezas fáticas, mas "não à indeterminação das mesmas normas, resultante da sua formulação em termos linguisticamente vagos". Não obstante isso, ele duvida que haja plena liberdade do legislador em definir as prognoses quanto ao planejamento do acesso ao ensino ou à evolução dos serviços de saúde, de modo a contrariar imposições constitucionais ${ }^{516}$.

A possibilidade de se controlar erros de prognose deve ser vista com muita cautela, pois, justifica ainda mais o receio de se relegar a atividade legislativa à função menor de mera execução da norma constitucional: neste caso, a mera regulamentação da vontade da jurisdição constitucional. E, por conseguinte, faz despertar o questionamento sobre até que ponto esse artifício conjuga-se com os objetivos da abertura das normas constitucionais (se é que há mesmo semelhante harmonização) e, em última análise, com o princípio democrático.

Para além disso, o reconhecimento de uma omissão inconstitucional por um erro de prognose esbarra na questão de se avaliar esse fenômeno como uma realidade concreta e atual e não eventual $^{517}$. Bem vistas as coisas, afinal, mesmo que se admita a

Políticos y Constitucionales, $\mathrm{n}^{\mathrm{o}}$ 7, 2003, pp. 479-493, especificamente, p. 492: "las ideias de una colegislación y compensación de un déficit político no son parte de la tarea judicial. La función de la Corte Constitucional, que controla la constitucionalidad de las leyes, consiste en hacer una defensa más bien conservadora de la Constitución contra un embate de la mayoría parlamentaria. Si la Corte Constitucional cumple una funcíon legislativa, será en todo caso una legislación negativa como ocorre cuando se declara la nulidad de cierta norma legal. Sus argumentos con los que fundamenta la nulidad de la ley puede contener sugerencias para mejorar la legislación. La decisión de recoger estas sugerencias, o preferir una solución constitucional alternativa, es responsabilidad exclusiva de la mayoría parlamentaria, como institución encargada de legislar".

515 Como fez SCHNEIDER, Hans Peter. Democracia y Constitución. Madri : Centro de Estudios Constitucionales, 1991, p. 201 e ss.

${ }^{516}$ Cf. CANOTILHO, J. J. Gomes. Direito Constitucional e teoria da Constituição, cit., p. 1317

${ }^{517}$ Cf. MIRANDA, Jorge. Manual de Direito Constitucional. Tomo VI, cit., p. 309. 
existência de um dever de adequação das leis vigentes, essa parece ser mais uma hipótese em que a solução para o adimplemento é muito mais de ordem política que jurídica. Ou, talvez por isso, nos casos aqui apresentados, ao invés de perquirir sobre prognoses, para, ao final, reconhecer ou não o cumprimento de um dever de legislar (e, em caso negativo, optar-se pela declaração de inconstitucionalidade) a melhor solução seja mesmo a de declarar a inconstitucionalidade da lei em controle por ação, quando se poderia, em exercício hermenêutico, ousado, é verdade, avaliar sobre a adequação (ou não) do tempo presente aos fins da lei ${ }^{518}$.

\subsubsection{O dever de reposição da igualdade}

Finalmente, refira-se brevemente à obrigação de reposição da igualdade. Conforme Vanice Regina Lírio do Valle, ao lado da determinação explícita da Constituição para que se produza uma lei, fator esse visto à exaustão nesse trabalho, o outro parâmetro de qualificação da omissão legislativa liga-se ao dever de o Poder Público observar o princípio da isonomia $^{519}$. De fato, já foi explicitado nesse trabalho que a reposição da igualdade pela jurisdição constitucional confunde-se com a própria gênese do reconhecimento do silêncio legislativo como omissão inconstitucional.

Geralmente, a inobservância desse dever específico deriva de: a) uma exclusão implícita ou silêncio excludente ${ }^{520}$; b) uma exclusão expressa; c) um duplo tratamento ${ }^{521}$. Nos dois primeiros casos, o indivíduo ou categoria busca incluir-se no grupo previsto no dispositivo. No terceiro, os prejudicados buscam intensificar o tratamento recebido, para que fique no nível concedido aos demais ${ }^{522}$ É nesse campo que as inconstitucionalidades por omissão e por ação costumam se comunicar, haja vista que, em certos casos, é difícil afirmar se se está diante de uma omissão do legislador ou de uma ação insuficiente ${ }^{523}$. Há

\footnotetext{
${ }^{518}$ Solução esta defendida por MORAIS, Carlos Blanco. Justiça Constitucional, tomo II, cit., p. 482.

${ }^{519}$ Cf.VALLE, Vanice Regina Lírio do. Sindicar a omissão legislativa..., cit., p. 161.

${ }^{520} \mathrm{Cf}$. BEILFUSS, Markus González. Tribunal Constitucional y reparación de la discriminación normativa, cit. p. 33-40.

${ }^{521}$ Sobre essa categorização conferir: SILVA, Jorge Pereira da. Dever de legislar e protecção jurisdicional contra omissões legislativas..., cit., p. 80.

${ }_{522}$ Cf. SILVA, Jorge Pereira da. Dever de legislar e protecção jurisdicional contra omissões legislativas, cit., p.81.

${ }^{523}$ Nesse sentido, Jorge Miranda afirma que "em caso de omissão legislativa parcial (...) tudo estará não em paralisar a concretização já alcançada, mas em procurar obter, por meio dos mecanismos de fiscalização da inconstitucionalidade por omissão, por ténues que sejam (art. $283^{\circ}$ ), o suprimento da omissão; só, no limite, quando se tiverem criado verdadeiros privilégios ou discriminações arbitrários, deverá ser julgada
} 
quem sustente que a inconstitucionalidade por omissão nos três casos, pois seriam substancialmente iguais ${ }^{524}$.

Não se pode concordar com essa posição. Nas hipóteses em que o legislador explicitamente exclui um grupo, o que há ali é obviamente uma atitude inconstitucional, mas não pelo que ele não disse, mas efetivamente na parte por ele regulada. Logo, a inconstitucionalidade será por ação. A consequência é que caberá ao órgão de controle julgar inconstitucional a parte excludente, devolvendo-se a igualdade ${ }^{525}$.

inconstitucional a lei (MIRANDA, Jorge. Manual de Direito Constitucional, tomo IV. Direitos fundamentais. Coimbra : Coimbra editora, 2000, pp. 243-244).

${ }^{524}$ Cf. SILVA, Jorge Pereira da. Dever de legislar e protecção jurisdicional contra omissões legislativas..., cit., p.84.

${ }^{525}$ Assim: CANOTILHO, J. J Gomes. Direito Constitucional e Teoria da Constituição, cit. p. 1036. Sobre a "zona cinzenta" que envolve a omissão inconstitucional relativa e a inconstitucionalidade por ação, consultar: GALKOWICZ, Henrique Campos. Jurisdição constitucional da igualdade. Dissertação de mestrado, USP, 2014, p. 58. 


\section{CONCLUSÃO}

1) As relações entre o Parlamento e a Constituição não foram sempre as mesmas. As Constituições do período revolucionário e as do século XIX (período oitocentista) já faziam remissões ao legislador para que concretizassem as suas normas. É o período em que gozava de plena liberdade em relação à tomada da decisão de quando e se legislar.

No Brasil, a Constituição de 1824 não destoou desse pensamento, de modo que seu caráter eminentemente liberal fez do Parlamento não só seu intérprete, mas também seu guardião. A potestade parlamentar entra em declínio com a Constituição republicana de 1891, mas, ainda assim, não há qualquer objeção à plena liberdade de legislar. Isso porque, conquanto houvesse a incorporação na ordem constitucional brasileira de um sistema de controle de constitucionalidade inspirado no direito constitucional americano, dele também se extraíram modos de se classificar as normas constitucionais com base na capacidade de serem autoexecutáveis ou não. No caso negativo, a solução para a completa aplicação da norma seria aguardar até que o legislador a completasse, exarando a lei necessária para tanto.

Essa concepção ultrapassa o constitucionalismo liberal e, segundo a jurisprudência do STF, alcança Constituições nacionais que houveram adotado o "modelo" weimariano, como as de 1934, 1937 e 1946. Estas eram já Constituições de viés programático. Nada obstante, era vigorosa a adoção da classificação de normas constitucionais de matriz estadunidense baseada em normas autoexecutáveis e nãoautoexecutáveis. Neste último caso, enquanto o legislador não emanasse as leis necessárias para o preenchimento conteudístico da norma, nada poderia ser feito para aplicá-la diretamente, senão aguardar a iniciativa do Poder Legislativo. O silêncio do legislador era, portanto, modo legítimo de fazer política, devendo ser, em nome do princípio da separação de poderes, tolerado.

$\mathrm{Na}$ fase do constitucionalismo democrático, advindo após a Segunda Guerra Mundial, a supremacia constitucional consolidou-se também na Europa: as Constituições firmaram-se como fonte das fontes do ordenamento jurídico e como inspiradora de decisões políticas. As relações com o Parlamento se alteraram. Mesmo assim, as Constituições são vistas como uma ordem aberta, aptas a abarcar todos os espectros do pensamento político, que podem inclusive antagonizar-se, possibilitando que o governo 
eleito tenha condições de implantar seu programa, pelo menos em teoria, conforme explanado durante o período eleitoral.

A Constituição aberta é a que garante flexibilidade ao sistema, conferindo maior capacidade de movimentos aos poderes públicos quando da criação de políticas a serem seguidas. Assim, o "fechamento" do sistema cabe, de acordo com o princípio democrático, primordialmente ao legislador. Ao cumprir esse mister, não estará exercendo mera atividade executiva, mas sim a de regulamentação ou concreção, no âmbito da qual a liberdade de conformação ainda é imprescindível, mesmo que possa ser restringida

$\mathrm{Na}$ esfera do constitucionalismo nacional, somente a partir da Constituição de 1988, que nasceu na sob a influência do constitucionalismo democrático europeu, a liberdade do legislador passa a sofrer limitações, inclusive com a criação de instrumentos processuais específicos, como a ação direta de inconstitucionalidade por omissão e o mandado de injunção.

Na verdade, a liberdade para legislar obedece a uma gradação, que vai desde praticamente a ausência de limites, aproximando-se ainda do constitucionalismo oitocentista, até uma vinculação mais estreita.

2) A partir da ideia de vinculação (positiva) do legislador à Constituição é que se pode falar em controle da constitucionalidade de seu silêncio. Nada obstante, essa vinculação não é só jurídica. É também política, tanto é assim, que o principal autor de língua portuguesa precursor do estudo das omissões legislativas e da vinculação do legislador à Constituição (J. J. Gomes Canotilho) defendia que a saída para a concretização da Constituição deveria ser democrática e não pela atividade da jurisdição constitucional.

Mas é justamente pela expansão da atividade da jurisdição constitucional europeia, que passou a controlar os desvios legislativos que vulneravam o princípio da igualdade, que tem origem o reconhecimento da inconstitucionalidade por omissão. Atualmente, é ainda no âmbito da omissão relativa que os Tribunais Constitucionais da Europa Central costumam se ater e é para colmatá-la que foram desenvolvidas as principais técnicas de decisão que alcançaram os resultados mais eficazes. Tem, pois, origem mais prática que teórica, o que destoa da sua congênere comissiva. Destacam-se, quanto ao reconhecimento do silêncio legislativo como algo também vulnerador da Constituição, o Tribunal Constitucional Federal alemão e a Corte Constitucional italiana. 
O evoluir teórico dessa inconstitucionalidade traçou, como fundamento dessa lesão à Constituição, a infringência a um dever específico de legislar (e não somente a um simples dever geral de legislar). Duas correntes se formaram, quanto ao controle de constitucionalidade propriamente dito: ou se sanciona o próprio comportamento do legislador pelo silêncio inoportuno e inadequado, comunicando-lhe sobre a necessidade de se proceder à produção da lei exigida (corrente "obrigacionista"), ou, simplesmente, se afasta a norma implícita inconstitucional, surgida a partir da omissão legislativa, mediante a integração da lei ordinária, na parte que ela não disse, mas deveria dizer.

As críticas à inconstitucionalidade por omissão, se não permitem que o instituto seja aceito de forma unânime e pacífica pela doutrina, não foram capazes de conter o alastramento do combate desse fenômeno a outros países, como Espanha e, principalmente, Portugal e Brasil, cujas Constituições expressamente preveem ações específicas para tanto.

No Brasil, a doutrina e a jurisprudência, firmes na sua origem "obrigacionista", organizaram um conceito de inconstitucionalidade por omissão a partir das imposições constitucionais, representadas por normas constitucionais de eficácia limitada (normas preceptivas não exquíveis por si mesmas, na classificação adotada neste trabalho). De consequência, há uma correspondência automática entre normas dessa estirpe, reserva de lei, dever de legislar e, consequentemente, inconstitucionalidade por omissão.

A frustração de um dever específico de legislar, conforme se entende no Brasil, ainda mais se for levada em conta a existência do mandado de injunção, faz nascer ao prejudicado pela omissão legislativa, um direito à norma, entendido por alguns ao direito à legislação e à própria efetividade da Constituição.

Afastadas as teses segundo as quais a omissão legislativa é inconstitucional somente quando a própria Constituição fixa prazo certo ao legislador para a produção de leis ou, por outro lado, o legislador omisso já provoca uma inconstitucionalidade imediatamente após a Constituição entrar em vigor, conclui-se que a passagem de um tempo razoável é fator a ser levado em conta, quando da caracterização daquele fenômeno. No âmbito jurisprudencial, o tempo é tomado sob dois aspectos: ou o Tribunal Constitucional declara uma omissão inconstitucional após constatar que já se passou tempo suficiente para que determinada norma constitucional fosse concretizada ou simplesmente fixa prazo para declarar a inconstitucionalidade, podendo mesmo ocorrer as duas situações 
simultaneamente. Nada obstante, é de eficácia duvidosa a segunda providência, tendo em vista que não há mecanismos para a sanção do legislador que não obedecer o lapso temporal que lhe foi demarcado pela jurisdição constitucional.

As omissões inconstitucionais têm sido classificadas sob diversos critérios. Seja pela intensidade da falta de cumprimento da norma (absolutas e relativas), seja pela extensão (total e parcial), ou ainda pela possibilidade ou não de serem preenchidas pela atividade hermenêutica (substituíveis ou impuras e insubstituíveis ou puras).

3) Os deveres de legislar também podem ser analisados e delimitados a partir de certos critérios. Pode-se partir de um âmbito mais geral, até chegar em situações particulares. Nesse sentido, a atribuição de competência configura-se como mero dever geral de legislar, de natureza permissiva ou autorizativa, de modo que a omissão legislativa verificada quanto ao não exercício dessas normas, não gera uma inconstitucionalidade.

Para a qualificação de uma inconstitucionalidade por omissão, é preciso que outros elementos sejam agregados à competência. Estes elementos geralmente são o prazo certo fixado pela própria norma constitucional e também uma reserva de lei imperativa.

O prazo fixado pela norma é o critério mais seguro de identificação de um dever específico, pois neste caso, está clara a intenção da Constituição em exigir de modo peremptório a produção legislativa. No entanto, podem ocorrer casos em que a fixação de prazo não justifica uma inconstitucionalidade por omissão, como ocorre nas leis orçamentárias.

A reserva de lei imperativa pode ser identificada a partir da qualidade do vínculo imposto ao legislador e também em função da própria terminologia empregada pela Constituição.

Diante de certas características presentes em determinadas normas constitucionais, no entanto, nem mesmo o descumprimento de uma reserva de lei imperativa dá causa a uma omissão inconstitucional. Essas características avultam a ligação política do legislador com a Constituição, o que faz com que a liberdade de conformação se amplie muito, a ponto de não poder ser sindicável pelo controle de constitucionalidade por omissão. É o caso de normas que demandam decisões de cunho eminentemente político e, geralmente, pelas normas programáticas. Algumas normas programáticas, no entanto, podem justificar uma declaração de inconstitucionalidade por omissão porque o constituinte dotou-as de conteúdo determinado ou, pelo menos, 
determinável. O problema está que, como essas normas servem para dar maleabilidade ao sistema jurídico, o fechamento delas, ainda que no âmbito constitucional, inibe a implementação de programas de governo eleito com base em concepções políticas divergentes da própria norma constitucional, o que descaracteriza a Lei Fundamental como ordem aberta.

Finalmente, pela explicitação desses critérios, demonstrou-se que o atual conceito de omissão inconstitucional de que faz uso tanto a doutrina quanto o STF é insuficiente para a exata compreensão desse fenômeno. Isso porque não há a correspondência direta e automática entre uma norma preceptiva não exequível por si mesma e um dever específico de legislar. Disso decorre que nem sempre a Constituição atribui ao legislador um dever concreto de legislar, mesmo quando faz uso da reserva de lei. 


\section{BIBLIOGRAFIA}

ACKEL FILHO, Diomar. Writs constitucionais (habeas corpus, mandado de segurança, mandado de injunção, habeas data). $2^{\mathrm{a}}$ ed. São Paulo: Saraiva, 1991.

ALEXY, Robert. Teoria dos direitos fundamentais. São Paulo : Malheiros editores, 2008.

ALMEIDA, Fernando Dias Menezes de. Considerações sobre a função do Senado Federal de suspender execução de lei declarada inconstitucional pelo Supremo Tribunal. Revista de informação legislativa. v. 44, n. 174, p. 15-24, abr./jun. 2007, 04/2007. Disponível em http://www2.senado.leg.br/bdsf/bitstream/handle/id/140960/R174-18.pdf?sequence=2.

Acesso em 27/12/1014, às 22:00h.

ANDRADE, José Carlos Vieira de. Os direitos fundamentais na Constituição portuguesa de 1976. $5^{\text {a }}$ ed. Coimbra : Almedina, 2012.

BARBI, Celso Agrícola. Supremo Tribunal Federal. Funções na Constituição Federal de 1988. Revista Forense. Rio de Janeiro, v. 85 nº 308, out-dez 1989.

. Mandado de injunção. In TEIXEIRA, Sálvio de Figueiredo (coord.). Mandados de segurança e injunção. São Paulo : Saraiva, 1990.

BARBOSA, Rui. Commentários á Constituição Federal Brasileira. São Paulo : Saraiva \& Cia., 1933.

BARROSO, luis Roberto. O controle de constitucionalidade no direito brasileiro : exposição sistemática da doutrina e análise crítica da jurisprudência. São Paulo : Saraiva, 2004.

Renovar, 1995.

O Direito Constitucional e a Efetividade de suas normas. Rio de Janeiro :

BASTOS, Celso Ribeiro. Curso de direito constitucional. 22 a ed. São Paulo : Malheiros, 2010.

.; BRITO, Carlos Ayres de. Intepretação e aplicabilidade das normas constitucionais. São Paulo : Saraiva, 1982.

BAZÁN, Victor. Hacia la plena exigibilidad de los preceptos constituconales: el control de las omisiones inconstitucionales. Especial referencia a los casos de Brasil y Argentina. In BAZÁN, Victor (coord.). Inconstitucionalidad por omisión. Santa Fé de Bogotá, Colômbia : Editorial Temis, 1997.

BÉGUIN, Jean-Claude. Le contrôle de la constitutionnalité des lois en République Féderale d'Allemagne. Paris : Economica, 1982.

BEILFUSS, Markus Gonzalez. Tribunal Constitucional y reparación de la discriminación normativa. Madri : centro de estudios políticos e constitucionales, 2000.

BELLOCCI, Mario; PASSAGLIA, Paolo. Parte II. La giurisprudenza costituzionale. In ITALIA. Corte Costituzionale. Problemi dell'omissione legislativa nella giurisprudenza costituzionale. Quaderno predisposto in occasione della Conferenza delle Corti 
Costituzionali europee. Vilnius 2-7 junho 2008, p. 31. Disponível em http://www.cortecostituzionale.it/documenti/convegni_seminari/STU199_Omissione_legis latore.pdf. Acesso em 15/10/2013, às 16:00h.

BENVINDO, Juliano Zaiden. Mandado de Injunção em Perigo: Os Riscos da Abstração de Seus Efeitos no Contexto do Ativismo Judicial Brasileiro. Observatório da jurisdição constitucional. Brasília : IDP, Ano 5, 2011/2012. Disponível em http\|www.portaldeperiodicos.idp.edu.br|índex.php|observatório|issue|current. Acesso em 19 de outubro de 2011, às 17:30h.

BERCOVICI, Gilberto. Constituição e política: uma relação difícil. Lua Nova. São Paulo, n. 61, 2004. Disponível em: http://www.scielo.br/scielo.php?script=sci_arttext\&pid=S01024452004000100002\&lng=e n\&nrm=iso. Acesso em 20/08/2014, às 15:00h.

A Constituição Dirigente e a Crise da Teoria da Constituição. In SOUZA NETO, Cláudio Pereira; BERCOVICI, Gilberto; MORAES FILHO, José Filomeno; LIMA, Martonio Mont'alverne Barreto. Teoria da Constituição. Estudos sobre o lugar da Constituição no Direito Constitucional. Rio de Janeiro : Lumen Juris, 2003.

Entre o Estado Total e o Estado Social. Atualidade no debate sobre direito, Estado e economia na República de Weimar. Tese de Livre-Docência. USP, 2003.

BERNARDES, Juliano Taveira. Controle abstrato de constitucionalidade. Elementos materiais e princípios processuais. São Paulo : Saraiva, 2004.

BICKEL, Alexander M. The Least Dangerous Branch. The Supreme Court at the Bar of Politic. New Haven e Londres : Yale University Press, 2a ed., 1986.

BITTENCOURT, Lucio. O controle jurisdicional da constitucionalidade das leis. $2^{\mathrm{a}}$ ed. Rio de Janeiro : Forense, 1968.

BOBBIO, Norberto. Teoria do Ordenamento Jurídico. São Paulo : Edipro, 2011.

BOCCATO, Esdras. Modulação dos efeitos temporais da declaração de inconstitucionalidade: ponderação, subsunção e dosimetria. Dissertação de mestrado. USP, 2013.

BÖCKENFORDE, Ernst-Wolfgang. Estudios sobre el Estado de Derecho y la Democracia. Madri : Editorial Trotta, 2000.

BONAVIDES, Paulo. Curso de Direito Constitucional. 26a ed. São Paulo : Malheiros editores, 2011.

BUENO, José Antônio Pimenta, marquês de São Vicente. Direito Público Brasileiro e a análise da Constituição do Império. São Paulo : Editora 34.

CALLEJÒN, Francisco Balaguer; VILLAR, Gregorio Cámara; AGUILAR, Juan Fernando López; BUESO, Juan Cano; CALLEJÓN, María Luisa Balaguer; RODRÍGUEZ, Ángel. Derecho Constitucional. Madri : Tecnos, 2003.

CAMPOS, Francisco. Direito Constitucional. Rio de Janeiro : Revista Forense, 1942. 
Direito Constitucional. II Volume. São Paulo e Rio de Janeiro : Livraria Freitas Bastos S/A, 1956.

CANOtilho, J J Gomes. Direito Constitucional e Teoria da Constituição. Coimbra : Almedina, 2003.

- Constituição Dirigente e vinculação do legislador. Contributo para a compreensão das normas constitucionais programáticas. Coimbra : Coimbra editora, 1994.

Tomemos a sério o silêncio dos poderes públicos - o direito à emanação de normas jurídicas e a proteção judicial contra as omissões normativas. In TEIXEIRA, Sálvio de Figueiredo (org.). As garantias do cidadão na justiça. São Paulo : Saraiva, 1993.

; MOREIRA, Vital. Constituição da República portuguesa anotada. $2^{\mathrm{a}}$ ed. Coimbra : Coimbra editora, 1984.

CAPPELLETTI, Mauro. O controle de constitucionalidade das leis no direito comparado. Porto Alegre: Sergio Antônio Fabris Editor, 1992.

CARRÉ DE MALBERG, Raymond. Teoria General del Estado. Cidade do México : Fondo de Cultura Económica, 1998.

CASSEB, Paulo Adib. Processo Legislativo. Atuação das comissões permanentes e temporárias. São Paulo : Editora Revista dos Tribunais, 2008.

CASTRO, Raquel Alexandra Brízida. As omissões normativas inconstitucionais no direito constitucional português. Coimbra : Almedina, 2012.

CAVALCANTI, João Barbalho Uchoa. Constituição Federal Brasileira: Commentarios. Rio de Janeiro : F. Briguiet e Cia Editores, 1924.

CERRI, Augusto. Corso di Giustizia Costituzionale. $5^{\text {a }}$ ed. Millão : Giuffrè Editore, 2008.

CHATELÊT, François; DUHAMEL, Olivier; KOUCHNER, Evelyne Pisier. História das ideias politicas. Rio de Janeiro : Zahar, 2009.

CLÈVE, Clèmerson Merlin. A atividade legislativa do Poder Executivo. São Paulo : Editora Revista dos Tribunais, 2000.

. Atividade legislativa do poder executivo. $2^{\mathrm{a}}$ ed. São Paulo : Editora Revista dos Tribunais, 2011, p. 54

A fiscalização abstrata da constitucionalidade no direito brasileiro. $2^{\mathrm{a}}$ ed. São Paulo : Editora Revista dos Tribunais, 2000.

COMPARATO, Fábio Konder. A afirmação histórica dos direitos humanos. $7^{\mathrm{a}}$ ed. São Paulo : Saraiva, 2010.

- Muda Brasil - uma Constituição para o Desenvolvimento Democrático. São Paulo : editora Brasiliense, 1986. 
CORWIN, Edward. The "Higher Law" background of American Constitution. Indianapolis : Liberty Fund, 2008.

COSTA, Carolina Popoff Ferreira da. Fundo de Garantia das Execuções Trabalhistas. Dissertação de mestrado. USP, 2011.

CRISAFULLI, Vezio. Lezioni di Diritto Costituzionale. Vol. II2. Pádua (Italia) : CEDAM, 1978.

. La corte costituzionale ha vent'anni. In OCCHIOCUPO, Nicola. La corte costituzionale tra norma giuridica e realtà sociale. Bilancio di vent'anni di attività. Padova : CEDAM, 1984.

. La costituzione e le sue disposizioni di principio. Milão : Giuffré, 1952.

CUNHA JÚNIOR Dirley da. Controle judicial das omissões do poder público. Em busca de uma dogmática constitucional transformadora à luz do direito fundamental à efetivação da Constituição. São Paulo : Saraiva, 2004.

DANTAS, Ivo. $O$ valor da constituição. Do controle de constitucionalidade como garantia da supralegalidade constitucional. $2^{\mathrm{a}}$ ed. Rio de Janeiro : Renovar, 2001.

DIEZ-PICAZO, Luis María. Concepto de ley y tipos de leyes.¿Existe una noción unitaria de ley en la Constitución española? Revista Española de Derecho Constitucional, ano 8, n. 24, set/dez 1988. Disponível em www.bibliotecadigital.inap.es/Datos/Publicaniones_Periodicas/REDC/24/REDC_24_047.pdf. Acesso em 11/12/2014, às 16:00h.

DIMOULIS, Dimitri; LUNARDI, Soraya. Curso de Processo Constitucional. São Paulo : Atlas, 2011.

.; MARTINS, Leonardo. Teoria Geral dos Direitos Fundamentais. São Paulo : Editora Revista dos Tribunais, 2009.

DINIZ, Maria Helena. Norma Constitucional e seus efeitos. São Paulo : Saraiva, 1998.

ENGISCH, Karl. Introdução ao pensamento jurídico. Lisboa : Fundação Calouste Gulbenkian. $8^{\mathrm{a}}$ ed. 2001.

ENTERRIA, Eduardo García de. La constitución como norma y el tribunal constitucional. Madri : Civitas, 1985.

.; FERNÁNDEZ, Tomáz-Ramón. Curso de Derecho Administrativo. Vol I. Navarra : Thomson-Civitas, 2008.

FERRARI, Regina Maria Macedo Nery Ferrari. Efeitos da declaração de inconstitucionalidade. $4^{\mathrm{a}}$ ed. São Paulo : Editora Revista dos Tribunais, 1999.

FERRAZ, Anna Cândida da Cunha. Processos informais de mudança da Constituição. São Paulo : Editora Max Limonad, 1986.

FERRAZ JUNIOR, Tércio Sampaio. Introdução ao estudo do direito. Técnica, decisão, dominação. $2^{\mathrm{a}}$ ed. São Paulo : Atlas, 1994. 


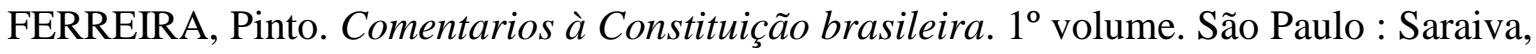
1989.

FERREIRA FILHO, Manoel Gonçalves. Estado de Direito e Constituição. São Paulo : Saraiva, 2007.

. Direitos Humanos Fundamentais. 13ª ed. São Paulo : Saraiva, 2011.

Do processo legislativo. $7^{\mathrm{a}}$ ed. São Paulo : Saraiva, 2012.

Curso de direito constitucional. $35^{\mathrm{a}}$ ed. São Paulo : Saraiva, 2009.

. Comentários à Constituição de 1988. Vol. I. São Paulo : Saraiva, 2000.

FIGUEIREDO, Marcelo. O mandado de injunção e a inconstitucionalidade por omissão. São Paulo : Editora Revista dos Tribunais, 1991.

FIORAVANTI, Maurizio. Costituzionalismo. Percorsi della storia e tendenze attuali. Roma : Editori Laterza, 2009.

. Stato e costituzione. Materiali per una storia delle dottrine costituzionali. Turim :

G. Giappicheli Editore, 1993.

FORSTHOFF, Ernst. Lo stato della società industriale. Milão : Giuffrè, 2011.

Concepto y esencia del Estado Social del Derecho. In ABENDROTH, Wolfgang; FORSTHOFF, Ernst; DOEHRING, Karl. El Estado Social. Madri : Centro de Estudos Constitucionales, 1986.

FRIESENHAHN, Ernest. La giurisdizione costituzionale nella Repubblica Federale tedesca. Quaderni della giurisprudenza costituzionale. Milão : Giuffrè editore, 1973.

GALKOWICZ, Henrique Campos. Jurisdição constitucional da igualdade. Dissertação de mestrado, USP, 2014.

GERHARDT, Michael. Problems of legislative omission in the Federal Constitutional Court's case law. In Report by the Federal Constitutional Court for the XIVth Congress of European Constitutional Courts. Vilnius, 2008, p. 41 e 43. Disponível em http://www.confeuconstco.org/reports/rep-xiv/report_Germany_en.pdf. Acesso em 20/08/2013, às 09:00h.

GOMES, Felipe Lima; TALEIRES, Janaína Sena. A liberdade de conformação do legislador no âmbito dos direitos fundamentais. Disponível em www.publicadireito.com.br/artigos/?cod=d3696cfb815ab692. Acesso em 20/10/2013, às $15: 00 \mathrm{~h}$.

GRAU, Eros Roberto. A ordem econômica na Constituição de 1988. São Paulo : Malheiros, 2010.

Ensaio e discurso sobre a interpretação/aplicação do direito. $5^{\mathrm{a}}$ ed. São Paulo : Malheiros, 2009. 
A constituinte e a constituição que teremos. São Paulo : Editora Revista dos Tribunais, 1985. 2010. A ordem econômica na Constituição de 1988. 14ª ed. São Paulo : Malheiros, Resenha do Prefácio da $2^{a}$ edição. In COUTINHO, Jacinto Nelson de Miranda (org.). Canotilho e a constituição dirigente. Rio de Janeiro : Renovar, 2003.

GUASTINI, Riccardo. Das fontes às normas. São Paulo : Quartier Latin, 2005.

HÄBERLE, Peter. Per una dottrina della Costituzione come scienza della cultura. Roma : Carocci, 2001.

La garantia del contenido esencial de los derechos fundamentales. Madri : Dykinson, 2003.

HAGE, Jorge. Omissão inconstitucional e direito subjetivo. Brasília : Brasília Jurídica, 1999.

HAMILTON, Alexander; JAY, John; MADISON, James. O federalista. São Paulo : Russell Editores, 2010.

HESSE. Konrad. Temas fundamentais de direito constitucional. São Paulo : Editora Saraiva, 2009.

. Elementos de Direito Constitucional da República Federal da Alemanha. Porto Alegre : Sérgio Antônio Fabris editor, 1998.

HORTA, Raul Machado. Direito Constitucional. $5^{\text {a }}$ ed. Belo Horizonte : Del Rey Editora, 2010.

IANUCCILLI, Loris. Parte I. Profili storici e teorici. In ITALIA. Corte Costituzionale. Problemi dell'omissione legislativa nella giurisprudenza costituzionale. Quaderno predisposto in occasione della Conferenza delle Corti Costituzionali europee. Vilnius 2-7 junho 2008, $\quad$ p. $\quad 8 . \quad$ Disponível http://www.cortecostituzionale.it/documenti/convegni_seminari/STU199_Omissione_legis latore.pdf. Acesso em 15/10/2013, às 15:00h.

KELLY, Octavio. Manual de jurisprudência federal. $1^{o}$ supplemento. Rio de Janeiro : Revista dos Tribunaes, 1917.

KELSEN, Hans. Teoria geral das normas. Porto Alegre: Sérgio Antônio Fabris Editor, 1986.

. Teoria geral do direito e do Estado. $4^{\mathrm{a}}$ ed. São Paulo : Martins Fontes, 2005.

Teoria Pura do Direito. São Paulo : Martins Fontes, 2011.

KRIELE, Martin. Introducción a la Teoria del Estado. Fundamentos históricos de la legitimidad del Estado constitucional democrático. Buenos Aires : Depalma, 1980. 
LARENZ, Karl. Metodologia da Ciência do Direito. $3^{\mathrm{a}}$ ed. Lisboa : Fundação Calouste Gulbenkian, 1997.

LASSALLE, Ferdinand. O que é uma Constituição? Belo Horizonte : Editora Líder, 2008.

LEAL, Roger Stiefelmann. O efeito vinculante na jurisdição constitucional. São Paulo : Saraiva, 2006.

Direitos sociais e a vulgarização da noção de direitos fundamentais. Disponível em http://www.ufrgs.br/ppgd/doutrina/leal2.htm. Consultado em 13/08/2014, às 17:00h.

Pluralismo, políticas públicas e a Constituição de 1988: considerações sobre a práxis constitucional brasileira 20 anos depois. In MORAES, Alexandre (coord.). Os 20 anos da Constituição da República Federativa do Brasil. São Paulo : Editora Atlas, 2009.

LEONCY, Léo Ferreira. "Princípio da simetria" e argumento analógico. O uso da analogia na resolução de questões federativas sem solução constitucional evidente. Tese. USP, 2011.

LOCKE, John. Dois tratados sobre o governo. São Paulo : Martins Fontes, 2005.

LLORENTE, Rubio Francisco. La forma del Poder (estudios sobre la Constitución). Madri : Centro de Estudios Constitucionales, 1993.

La forma del Poder. Estudios sobre la Constitución. Estudios Constitucionales, v. I. Madri : Centro de Estudios Constitucionales, 2012.

Rango de ley, fuerza de ley, valor de ley (sobre el problema del concepto de ley en la Constitución. Revista de Administración Pública, nº 100-102, jan/dez 1983. Disponível em http://www.cepc.gob.es/eu/argitalpenak/ aldizkariak/aldizkarielektronikoak?IDR=1\&IDN=100\&IDA=23351. Acesso em 11/12/2014, às 18:00h.

LOEWENSTEIN, Karl. Teoria de la Constitución. Barcelona : Editorial Ariel, 1976.

MACHADO, Carlos Augusto Alcântara. Mandado de injunção. Um instrumento de efetividade da constituição. $2^{a}$ ed. São Paulo : Atlas, 2004.

MACIEL, Adhemar Ferreira. Mandado de injunção e inconstitucionalidade por omissão. In TEIXEIRA, Sálvio de Figueiredo (coord.). Mandados de segurança e injunção. São Paulo : Saraiva, 1990.

MARINHO, Josaphat. O art. 64 da Constituição e o papel do Senado. Revista de informação legislativa. v. 1, n. 2, p. 5-12, jun. 1964 Disponível http://www2.senado.leg.br/bdsf/bitstream/handle/id/180651/000347388.pdf?sequence=1. Acesso em 29/12/2014, às 17:30h.

MARSHALL, John. Decisões Constitucionais de Marshall. Tradução de Américo Lobo. Ministério da Justiça, 1997.

MATTEUCCI, Nicola. Lo stato. Bolonha : il Mulino, 1997. 
MAXIMILIANO, Carlos. Comentários á Constituição brasileira. $4^{\mathrm{a}}$ ed. São Paulo e Rio de Janeiro : Livraria e Editora Freitas Bastos, 1948.

MEIRELLES, Hely Lopes; WALD, Arnold; MENDES, Gilmar Ferreira. Mandado de segurança e ações constitucionais. 32 ${ }^{\mathrm{a}}$ ed. São Paulo : Malheiros Editores, 2009.

MELLO, Celso Antônio Bandeira de. Eficácia das normas constitucionais e direitos sociais. Malheiros editores, 2010.

MENDES, Gilmar. Jurisdição constitucional: o controle abstrato de normas no Brasil e na Alemanha. São Paulo : Saraiva, 1999.

. Apelo ao legislador na Corte Constitucional alemã. Revista Trimestral de Direito Público. São Paulo : Malheiros Editores, nº 10, 1995.

Mandado de Injunção. DPU, $\mathrm{n}^{\circ}$ 19, jan/fev 2008, p. 139. Disponível Em http://www.direitopublico.idp.edu.br/index.php/direitopublico/article/viewFile/387/964. Consultado em 10/04/2013, às 17:00h.

. O controle da omissão inconstitucional. In SCHÄFER, Jairo Gilberto (org.). Temas polêmicos do constitucionalismo contemporâneo. Florianópolis : Conceito editorial, 2007.

2006.

Direitos fundamentais e controle de constitucionalidade. São Paulo : Saraiva,

Questões fundamentais de técnica legislativa. Revista eletrônica sobre a reforma do Estado (RERE). Salvador : Instituto Brasileiro de Direito Público, $\mathrm{n}^{\circ} 11$, set/out/nov 2007, p. 3. Disponível em http://www.direitodoestado.com.br/rere.asp. Consultado em 11/12/2014, às 16:00h. Disponível em http://www.camara.gov.br/proposicoesWeb. Acesso em 19/12/2014, às 11:00h.

.; COELHO, Inocêncio Mártires; BRANCO, Paulo Gustavo Gonet. Curso de Direito Constitucional. São Paulo : Saraiva, 2010.

MENÉNDEZ, Ignacio Villaverde Menéndez. La inconstitucionalidad por omisíon. Madri : MaGraw-Hill, 1997.

MEZZETTI, L.; BELLETTI, M.; D’ORLANDO, E.; FERIOLI, E. Giustizia Costituzionale. Pádua : CEDAM, 2007, p. 436.

MIGUEL, Carlos Ruiz. Critica de la llamada inconstitucionalidad por omisión. Revista de las Cortes Generales. n. 51, 2001. Disponível em http://www.iidpc.org/revistas/2/pdf/175_193.pdf. Acesso em 27/06/2013, às 15:00h.

MIRANDA, Francisco Cavalcanti Pontes de. Comentários à Constituição de 1946. Vol I. $2^{a}$ ed. São Paulo : Max Limonad, 1953.

1960.

Comentários á Constituição de 1946. Tomo III. Rio de Janeiro : Editor Borsoi, 
Comentários à Constituição de 1967. Vol I. São Paulo : Editora Revista dos Tribunais, 1967.

MIRANDA, Jorge. Manual de Direito Constitucional. Tomo II. Coimbra editora, 2007.

Manual de Direito Constitucional. Inconstitucionalidade e garantia da Constituição. Tomo VI. $4^{\text {a }}$ ed. Coimbra : Coimbra Editora, 2013

Teoria do Estado e da Constituição. Coimbra : Coimbra editora, 2002.

. A fiscalização da inconstitucionalidade por omissão. Revista Direito e Liberdade. Esmarn, v. 14, nº 1, jan/jun 2012, pp. 14-21. Disponível em www.esmarn.tjrn.jus.br.

MODESTO, Paulo Eduardo Garrido. Inconstitucionalidade por omissão (categoria jurídica e ação constitucional específica). Revista de Direito Público, ano 24, nº 97, jan/mar 1991.

MORAES, Alexandre. Direito constitucional. 30ª ed. São Paulo : Editora Atlas, 2014.

MORAES, Leonardo de. Responsabilidade por omissão do Estado. Dissertação de mestrado. USP, 2007.

MORAIS, Carlos Blanco. Justiça Constitucional. Tomo II. O contencioso constitucional português entre o modelo misto e a tentação do sistema de reenvio. Coimbra : Coimbra editora, 2005.

O controlo de inconstitucionalidade por omissão no ordenamento brasileiro e a tutela dos direitos sociais: um mero ciclo activista ou uma evolução para o paradigma neoconstitucionalista? Revista de Direito Constitucional e Internacional, ano 20, $\mathrm{n}^{\mathrm{o}} 78$, jan-mar 2012.

MOREIRA, José Carlos Barbosa. Mandado de injunção. Revista de Processo, out-dez/89.

MOREIRA NETO, Diogo de Figueiredo. Constituição e Revisão. Temas de Direito Político e Constitucional. Rio de Janeiro : Forense, 1991.

MORTATI, Costantino. Appunti per uno studio sui rimedi giurisdizionali contro comportamenti omissivi del legislatore. Problemi di Diritto Pubblico nell'attuale esperienza costituzionale repubblicana. Problemi di diritto pubblico nell'attuale esperienza costituzionale repubblicana. Racolta di scritti III. Milão : Dott. A. Giuffrè editore, 1972.

. Istituzioni di Diritto Pubblico. Pádua : Cedam, 1975.

OBERNDORFER, Peter; WAGNER, Britta. Legislative omission as a problem of Constitutional Review. In AUSTRIA. Austrian Constitutional Court. Report of the Austrian Constitutional Court. XIV Congress of the Conference of European Constitutional Courts. Vilnius, Lituânia, 2-7 junho 2008. Disponível em www.confeuconstco.org/rep-xiv/report_Austria_en.pdf. Acesso em 15/10/2013, às 20:00h.

OLVERA, Óscar Rodríguez. Teoría de los derechos sociales en la constitución abierta. Granada : Editorial Comares, 1998. 
PAGÉS, Juan Luis Requejo. Los problemas de la omisión legislativa en la jurisprudencia constitucional. Ponencia del Tribunal Constitucional de España. XIV Conferencia de Tribunales Constitucionales Europeos. Vilna, mayo de 2008. Disponível em http://www.confeuconstco.org/reports/rep-xiv/report_Spain_sp.pdf. Acesso em 20/08/2013, às 15:00h.

Constitución y remisión normativa. Perspectivas estática y dinámica en la identificación de las normas constitucionales. Revista Española de Derecho Constitucional, ano 13, n. 39, 1993.

Sistemas normativos, Constitución y Ordenamento. La Constitución como norma sobre la aplicación de normas. McGraw-Hill, 1995.

PALU, Oswaldo Luiz. Controle dos atos de governo pela jurisdição. São Paulo : Editora Revista dos Tribunais, 2004.

PAPA LEÃO XIII. Carta Encíclica Rerum Novarum, sobre a condição dos operários. 1891. Disponível

em http://www.vatican.va/holy_father/leo_xiii/encyclicals/documents/hf_lxiii_enc_15051891_rerum-novarum_po. html. Acesso em 24/05/2014, às 10:00h.

PAPA PIO XI. Quadragesimo anno. 1931. Disponível em http://w2.vatican.va/content/pius-xi/pt/encyclicals/documents/hf_pxi_enc_19310515_quadragesimo-anno.html. Acesso em 24/05/2024, às 10:20h.

PASSOS, José Joaquim Calmon. Mandado de segurança coletivo, mandado de injunção, habeas data (constituição e processo). Rio de Janeiro : Forense, 1989.

PÉREZ, Diego Selhane. Aspectos constitucionais do mandado de injunção. Sentido jurídico-político, direitos tutelados e efeitos da decisão. Dissertação de mestrado. São Paulo : USP, 2000.

PFEIFFER, Roberto Augusto Castellanos. Mandado de injunção. São Paulo : Atlas, 1999.

PICARDI, Nicola. Le sentenze "integrative" della Corte costituzionale". Rivista di Diritto Processuale, ano XXX, nº 1. CEDAM, 1975.

PIÇARRA, Nuno. A separação de poderes como doutrina e princípio constitucional. Coimbra : Coimbra editora, 1989.

PINTO, Marcos Barbosa. Jurisdição Constitucional e Democracia. Tese de doutorado. USP, 2008.

PIOVESAN, Flávia C. Proteção judicial contra omissões legislativas. Ação direta de inconstitucionalidade por omissão e mandado de injunção. São Paulo : Editora Revista dos Tribunais, 1995.

- Proteção judicial contra omissões legislativas. $2^{\mathrm{a}}$ ed. Editora Revista dos Tribunais, 2003.

Constituição e transformação social: a eficácia das normas constitucionais programáticas e a concretização dos direitos e garantias fundamentais. Revista da 
Procuradoria Geral do Estado de São Paulo. São Paulo : Centro de Estudos, no 37, junho, 1992.

PIZZORUSSO, Alessandro. Lecciones de Derecho Constitucional. Vol II. Madri : centro de estudios constitucionales, 1984.

POCOCK. J. G. A. Linguagens do ideário político. São Paulo : Edusp, 2013.

POLETTI, Ronaldo. Controle da constitucionalidade das leis. $2^{\mathrm{a}}$ ed. Rio de Janeiro : Forense, 1997.

PUCCINELLI JÚNIOR, André. Omissão legislativa inconstitucional e responsabilidade do estado legislador. $2^{\mathrm{a}}$ ed. São Paulo : Saraiva, 2013.

PUENTE, Marcos Gómez. La inactividad del legislador: una realidad susceptible de control. Madrid : McGraw-Hill, 1997.

QUARESMA, Regina. O mandado de injunção e a ação de inconstitucionalidade por omissão. Teoria e prática. $2^{\mathrm{a}}$ ed. Rio de Janeiro : Editora Forense, 1995.

RAMOS, Elival da Silva. Controle de Constitucionalidade no Brasil. Perspectivas de evolução. São Paulo : Saraiva, 2010.

. Ativismo judicial. Parâmetros dogmáticos. São Paulo : Saraiva, 2010.

REALE, Miguel. Liberdade e Democracia. Em torno do Anteprojeto da Comissão Provisória de Estudos Constitucionais. São Paulo : Saraiva, 1987.

RIANI, Frederico Augusto D'Ávila. A vinculação do Chefe do Executivo à lei orçamentária no cumprimento das determinações constitucionais. Tese de doutorado, PUC/SP, 2008.

RIZEK JÚNIOR, Rubens Naman. Os Parlamentos frente às inovações do processo legislativo. Dissertação de mestrado. USP, 2001.

RODRIGUEZ, Jose Julio Fernandez. La inconstitucionalidad por omisión. Teoria General. Derecho comparado. El caso español. Editorial Civitas, 1998.

ROSA, André Vicente Pires. Las omisiones legislativas y su control constitucional. Rio de Janeiro : Renovar, 2006.

ROSS, Alf. Direito e justiça. Bauru : EDIPRO. $2^{\text {a }}$ ed. 2007, p. 57.

ROTHENBURG, Walter Claudius. Inconstitucionalidade por omissão e troca de sujeito. A perda de competência como sanção à inconstitucionalidade por omissão. São Paulo : Editora Revista dos Tribunais, 2005.

RUIZ, Maria Angeles Ahumada. El control de constitucionalidad de las omisiones legislativas. Revista del Centro de Estudios Constitucionales, n. 8, jan/abr 1991. Disponível em http://www.cepc.gob.es/publicaciones/revistas/fondohistorico? IDR=15\&IDN=1238\&IDA=35400. Acesso em 02/12/2014, às 15:00h. 
SAMPAIO, José Adércio Leite. O Estado Democrático de Direito. In HORBACH, Carlos Bastide; ALMEIDA, Fernando Dias Menezes de; AMARAL JÚNIOR, José Levi Mello do; LEAL, Roger Stiefelmann. Direito Constitucional, Estado de Direito e Democracia. Homenagem ao Prof. Manoel Gonçalves Ferreira Filho. São Paulo : Quartien Latin, 2011.

SARLET, Ingo Wolfgang. A eficácia dos direitos fundamentais. $8^{\mathrm{a}}$ ed. Livraria do Advogado : Porto Alegre, 2007.

SCHMITT, Carl. Teoría de la Constitución. Buenos Aires : Editorial Struhart \& Cia (sem data).

.; KELSEN, Hans. La polémica Schmitt/Kelsen sobre la justicia constitucional: El defensor de la Constitución versus ¿Quién debe ser el defensor de la Constitución? Madri : Tecnos, 2009.

SCHNEIDER, Hans Peter. Democracia y Constitución. Madri : Centro de Estudios Constitucionales, 1991.

SCHWABE, Jürgen. Cinquenta anos de jurisprudência do Tribunal Constitucional Federal alemão. Konrad-Adenauer-Stiftung E.V, 2005.

SEGADO, Francisco Fernandéz. El control de las omisiones legislativas por el "Bundesverfassungsgericht". Teoria y Realidad Constituional. UNED, n. 22, 2008. Disponível em http://www.juridicas.unam.mx/publica/librev/rev/trcons/cont/22/est/est2.pdf. Acesso em 20/10/2013, às 17:00h.

El control de constitucionalidad de las omisiones legislativas. Algunas cuestiones dogmáticas. Estudios Constitucionales, Año 7, $\mathrm{N}^{\mathrm{o}}$ 2, 2009. http://www.cecoch.cl/docs/pdf/revista_ano7-2-2009/estudios_el_control.pdf. Acesso em 20/04/2013, às 21:00h.

SHOLZ, Rupert. Alemania: cincuenta años de Corte Constitucional Federal. Anuario de Derecho Constitucional Latinoamericano. Konrad-Adenauer-Stiftung, 2002.

SIDOU. J.M. Othon. Haberas corpus mandado de segurança, ação popular. As garantias ativas dos direitos coletivos. Rio de Janeiro : Forense, 1992.

SILVA, Jorge Pereira da. Dever de legislar e protecção jurisdicional contra omissões legislativas. Contributo para uma Teoria da Inconstitucionalidade por Omissão. Coimbra : Universidade Católica Editora, 2003.

SILVA, José Afonso da. Aplicabilidade das normas constitucionais. $2^{\mathrm{a}}$ Ed. São Paulo : Saraiva, 1982.

2012.

Aplicabilidade das normas constitucionais. $8^{\mathrm{a}}$ ed. São Paulo : Malheiros editores, Curso de direito constitucional positivo. $36^{\mathrm{a}}$ ed. São Paulo : Malheiros Editores, 2013. 
O Estado Democrático de Direito. Revista da Procuradoria Geral do Estado. São Paulo : Centro de Estudos, nº 30, dez. 1988.

. Mandado de injunção. In TEIXEIRA, Sálvio de Figueiredo (org.). As garantias do cidadão na justiça. São Paulo : Saraiva, 1993.

. Mandado de injunção. In TEIXEIRA, Sálvio de Figueiredo (coord). Mandados de segurança e injunção. São Paulo : Saraiva, 1990.

SILVA, Virgílio Afonso da Silva. Direitos fundamentais. Conteúdo essencial, restrições e eficácia. $2^{a}$ ed. São Paulo : Malheiros, 2010.

SILVA, Volney Zamenhof de Oliveira. Lineamentos do Mandado de injunção. São Paulo : Editora Revista dos Tribunais, 1993.

SLAIBI FILHO, Nagib. Ação declaratória de constitucionalidade. $2^{\mathrm{a}}$ ed. Rio de Janeiro : editora Forense, 1995.

SOUZA, Luiz Henrique Boselli de. A correlação da efetividade das normas constitucionais com o suprimento das omissões normativas. Tese de doutorado. USP, 2010.

STARCK, Christian. La legitimación de la justicia constitucional y el princípio democrático. Anuario ibero-americano de justicia constitucional. Madri : centro de estudios políticos y constitucionales, $\mathrm{n}^{\circ}$ 7, 2003.

. El concepto de lei en la constitución alemana. Madri : Centro de estudos constitucionales, 1979.

STERN, Klaus. Derecho del Estado de la Republica Federal alemana. Centro de Estudios Constitucionales, 1987.

TÁCITO, Caio. Como fazer valer a Constituição? Revista de Direito Administrativo. Rio de Janeiro : Renovar/FGV, nº 242, out/dez 2005.

TAVARES, André Ramos. Tribunal e jurisdição constitucional. São Paulo : Celso Bastos editor, 1998.

TEIXEIRA, José Elaeres Marques. A doutrina das questões políticas no Supremo Tribunal Federal. Porto Alegre : Ségio Antônio Fabris Editor, 2005.

TEIXEIRA, J. H. Meirelles. Curso de Direito Constitucional. Florianópolis : Conceito Editorial, 2011.

. Curso de Direito Constitucional. Forense universitária, 1991.

TRIBE, Lawrence H. American Constitucional Law. $3^{\mathrm{a}}$ ed. Nova Iorque : Foundation Press, 2000.

TROCKER, Niccolò. Le omissioni del legislatore e la tutela giurisdizionale dei Diritti di Libertà. Studio comparativo sul diritto tedesco. Archivio Giuridico "Filippo Serafini", volume CLXXVIII, Fascícolos 1-2. Modena : S.T.E.M. Mucchi, Janeiro/Abril, 1970. 
TROPER, Michel. La théorie du Droit, le Droit, L'état. Paris : Presses Universitaires de France, 2001.

VALLE, Vanice Regina Lírio. Sindicar a omissão inconstitucional: real desafio à harmonia entre os poderes. Belo Horizonte : Editora Forum, 2007.

VAZ, Manuel Afonso. Lei e Reserva da Lei. A causa da lei na Constituição portuguesa de 1976. Coimbra : Coimbra editora, 2013.

VEGA, Augusto Martín de La. La sentencia constitucional en Italia. Madri : Centro de Estudios Políticos y Constitucionales, 2003.

VELOSO, Zeno. Controle jurisdicional de constitucionalidade. Belém : Cejup, 1999.

VERDÚ, Pablo Lucas. Teoría de la Constitución como ciencia cultural. Madri : Dykinson, 1998.

VERGOTTINI, Giuseppe de. Diritto Costituzionale. Pádua : CEDAM, 2006.

VILANOVA, Lourival. A dimensão política nas funções do Supremo Tribunal Federal. Revista de Direito Público, Ano XIV, ns. 57-58, Jan-jun 1981.

VILE, J. M. C. Constitucionalism and separation of powers. Indianapolis : Liberty Funds, 1998.

VILlALÓN, Pedro Cruz. La formación del sistema europeo de control de constitucionalidad (1918-1939). Madri : centro de estudios constitucionales, 1987.

WEAVER, Michael. Uncertainty Maintained: The Split Decision Over Partisan Gerrymanders in Vieth v. Jubelirer. Loyola University Chicago Law Journal, vol. 26, 2005, p. $1287 . \quad$ Disponível em http://www.luc.edu/media/lucedu/law/students/publications/llj/pdfs/weaver.pdf. Acesso em 19/09/2014, às 20:00h.

XAVIER, Alberto Pinheiro. Conceito e natureza do acto tributário. Coimbra : Livraria Almedina, 1972.

ZAGREBELSKY, Gustavo. Il diritto mite. Milão : Einaudi, 1992. .; MARCENÒ, Valeria. Giustizia costituzionale. Bolonha : il Mulino, 2012. 